UC-70B

Issued: June 1986

\title{
Los Alamos Low-Level Waste Performance Assessment Status
}

\author{
LA- -10768-MS \\ Compiled by \\ W. J. Wenzel \\ DE86 014887 \\ W. D. Purtymun \\ J. M. Dewart \\ J. C. Rodgers
}

\begin{abstract}
DISCLAIMER
This report was prepared as an account of work sponsored by an agency of the United States Government. Neither the United States Government nor any agency thereof, nor any of their employees, makes any warranty, express or implied, or assumes any legal liability or responsibility for the accuracy, completeness, or usefulness of any information, apparatus, product, or process disclosed, or represents that its use would not infringe privately owned rights. Reference herein to any specific commercial product, process, or service by trade name, trademark, manufactuier, or otherwise does not necessarily constitute or imply its endorsement, recommendation, or favoring by the United States Government or any agency thereof. The views and opinions of authors expressed herein do not necessarily state or reflect those of the United States Government or any agency thereof.
\end{abstract}

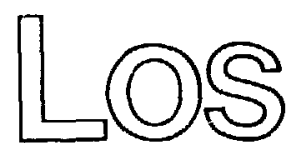


CONTENTS

ABSTRACT

1.0 SITE ENVIRONMENTAL STUDIES

1.1 GEOHYDROLOGY AND GEOCHEMISTRY

1.1.1 Setting

1.1.2 Historical

1.1.3 Geology

1.1 .4 Soils

1.1.5 Seismology

1.1.6 Geochemistry

1.2 METEOROLOGY

1.2.1 General Climatology

1.2.2 Precipitation

1.2 .3 Wind

1.2.4 Air Pollution

1.3 SUPPORTING DATA

1.3.1 Meteorological Monitoring

1.3.1.1 Atmospheric Dispersion Model ing

1.3.2 Environmental Surveillance Program

1.3.3 Solid Waste Site Surveillance Program

1.3.4 Preoperational Survey Baseline Program

1.3.5 Waste Management Studies

1.3.5.1 Area B Prerenovation Environmental Study

1.3.5.2 Comprehensive Environmental Assessment

and Response Program

1.3.5.3 Shallow Land Burial Studies

1.3.5.3.1 Biointrusion Barrier Testing

1.3 .5 .3 .2

Migration Barrier Testing

1.0 .5 .3 .3

Ground and Surface Water

Management Systems

1.3.5.3.4 Erosion Control Technology

1.3.5.3.5 Moisture Cycling Effects on

Chemical Transport

1.3.5.3.6 Subsidence Studies 80

REFERENCES

$\begin{array}{lll}2.0 & \text { SOURCE TERM DESCRIPTION } & 87\end{array}$

2.1 SOLID WASTES $\quad 87$

2.1.1 Description of Solid Waste Disposal Sites 88

2.1.2 Source Terms for Solid Waste Disposal Sites 95

2.1.2.1 Source Terms for Solidified Waste 95

2.1.2.2 Source Terms for Unsolidified Waste 99

2.2 HAZARDOUS CHEMICAL WASTES 102

2.3 DECONTAMINATION AND DECOMMISSIONING 103

$\begin{array}{lll}2.4 \text { EFFLUENT IMPACT ON CANYONS } & 104 \\ 2.0 \text { REF } & 108 \text { ERENCES }\end{array}$ 
3.0 PATHWAYS AND JUSTIFICATION

3.1 PATHWAYS FOR SOILS AND SEDIMENTS 111

3.2 PATHWAYS FOR BURIED WASTES 115

REFERENCES

4.0 ENVIRONMENTAL DOSIMETRY 122

4.1 ENVIRONMENTAL DOSE CALCULATIONS 122

4.2 RISK CALCULATIONS 126

4.2.1 Waste Alternatives Study Risk Analyses 126

4.2.2 Hansen and Rodgers Study 127

REFERENCES

4.2.3 Pantex EIS and BEIR III Risk Analyses 128

5.0 MODEL DOCUMENTATION, VERIFICATION, AND VALIDATION 133

5.1 GROUND WATER TRANSPORT MODELS 133

5.1.1 Hansen and Rodgers Model 133

5.1.2 TRACR3D Model 143

5.2 SURFACE WATER TRANSPORT MODELS 148

5.2.1 Multimedia Models 148

5.2.2 CREAMS Model 149

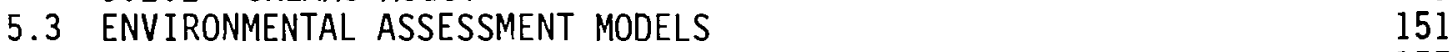

$\begin{array}{ll}\text { REFERENCES } & 157\end{array}$

$\begin{array}{ll}\text { ACKNOWLEDGMENTS } & 161\end{array}$

FIGURES

1.1 Regional Location of Los Alamos 3

1.2 Physiographic Features of the Los Alamos Area 4

1.3 Geology of Los Alamos County 6

1.4 Geologic Stratigraphic Relationships 7

1.5 General Geology of Los Alamos County and a Part of
Adjacent Santa Fe County

$\begin{array}{lll}1.6 & \text { Regional Surface Waters } & 14\end{array}$

1.7 Surface Drainage Areas Crossing or Originating on 16

1.8 Hydrological Cross Section 17

1.9 Generalized Contours on the Surface of the Main Aquifer 19

1.10 Technical Area (TA) and Weather Station (A-D) Locations 23

1.11 Annual Precipitation Amounts for Los Alamos 25

1.12 Annual Wind Roses for OHL 28

1.13 Annual Wind Roses for Area G 29

Summary of Estimated Maximum Individual and Maximum
Laboratory Boundary Doses from Laboratory Operations

1.15 Quarteriy Radiation TLD Measurements 36

1.16 Locations of Active (Area G) and Inactive Radioactive
Waste Disposal Areas

$\begin{array}{lll}1.17 & \text { Air Sampler Locations at Area G } & 44\end{array}$ 
1.18 Surface Water Gaging Station in Area G (TA-54) and Sediment Sampling Stations Adjacent to Area G and 46

1.19 Hydrology of Shallow-Land Disposal of Radioactive Wastes 55

1.20 Precipitation and Distribution of Water $30 \mathrm{~cm}$ Beneath the Biobarrier Treatments at Area G vs Time

1.21 Soii Water Content and Precipitation Data from Caisson Experiments

1.22 Soil Water Content and Precipitation Data from Area B Experiments

1.23 Biointrusion Barrier/Transport Experinent

1.24 Vertical Distribution of a Cobalt Tracer in Caissons

1.25 Hypothetical Wetting Curve for a Fine Sand and a Coarse Gravel

1.26 Hypothetical $k(\theta)$ Curves for a Fine Sand and a Coarse Gravel

1.27 Effect of Adding Bentonite to Los Alamos Tuff

1.28 Hydrograph, Sedjent Concentration, and Sedigraph Data Collected in 1983 from Plot 8 with Cultivated Treatment

1.29 Hydrograph, Sediment Concentration, and Sedigraph Data Collected in 1983 from Plot 3 with Bare Treatment

1.30 Hydrograph, Sediment Concentration, and Sedigraph Data Collected in 1983 from Plot 7 with the Gravel Cover Treatment

1.31 Hydrograph, Sediment Concentration, and Sedigraph Data Collected in 1983 from Plot 5 with Gravel and Wheatgrass Cover

1.32 Subsurface Water Content Data from Plot 6 with Bare Soil Treatment

1.33 Subsurface Water Content Data from Plot 1 with Cultivated Treatment

1.34 Tritium Inventory vs Depth for the Moisture Cycling Experiment (Experimental Units $5 A$ and $5 B$ )

1.35 Tritium Inventory vs Depth for the Moisture Cycling Experiment (Experimental Units $7 A$ and $7 B$ )

2.1 Canyon Water and Sediment Sampling Locations with Current and Former Major Effluent Discharge Points

$\begin{array}{ll}\text { 4.1 Calculation Flow for Long-Term Health Effects } & 129\end{array}$

5.1 Generalized Los Al amos Geohydrology Setting 134

5.2 Geometry of Well Parameters

5.3 Effect of Well Water Concentrations of Changes in Seepage Velocity

5.4 Water Pulse Moisture as a Function of Depth and Time

5.5 "Damping" of Moisture Pulses Under Field Conditions 


\section{TABLES}

1-1. Temperature and Precipitation Averages 1951-1980 22

1-2. 1984 Precipitation Totals 26

1-3. Precipitation Frequency Estimates for Los Alamos, New Mexico 26

1-4. Return-Period Wind Speeds for Los Alamos 30

1-5. Los Alamos Meteorological Tower Network 32

1-6. Number of Sampling Locations $\quad 34$

1-7. External Penetrating Radiation Measurements at Waste $\quad 40$

1-8. Radionuclide Concentrations in Soils and Bedrock at the Low-Level Radioactive Waste Management Areas During $1983 \quad 41$

1-9. 1984 Air Sampling Results for Fourth Quarter at Area G (TA-54) 43

1-10. Radionuclide Concentrations in Perimeter Soil Samples from Waste Management Areas B and C

1-11. Radiochemical Analyses of Sediments and Run-0ff at Area G (TA-54)

1-12. Radiochemical Analyses of Sediment and Run-0ff Samples from Area G (TA-54)

1-13. Average Run-Off, Run-Off/Precipitation Radios, and Soil Loss for Rain Simulator Runs Perforined in 1983 on Dry, Wet, and Very Wet Soil Surfaces on Erosion Plots as a Function of Surface Treatment

1-14. Soil Loss, cover Management Factor (C), and Gravel and Plant Cover Estimates for the Trench Cap Plots with Gravel and Gravel Plus Wheatgrass Cover (1983) Data

1-15. Relationship of Subsidence to Width $(W)$ and Depth (k)

73

81

2-1. Description of Solid Waste Disposal Sites 89

2-2. Solidified Alpha Wastes at Los Alamos 95

2-3. Composition of Plutonium Isotopes Expressed as Weight Fraction 97

2-5. Comparison Between Computed Average Concentration and Measured Concentration of Defense Waste in Area $\mathrm{T}(\mathrm{Ci} / \mathrm{g})$

2-6. Source Term ( $\mathrm{Ci} / \mathrm{yr})$ from Los Alamos Solidified TRU Waste

2-7. Average Leachate/Waste Ratios from Maxey Flats and West Valley Sites (empirically derived)

2-8. Unsolidified TRU Waste Concentration Based on Area C Data

2-9. Source Terms ( $\mathrm{C}$ / year) for Los Alamos Unsolidified TRU Waste

3-1. Per Cent of TRU Wastes from the Los Alamos Plutonium Facility

4-1. 1983 Population Distribution Within $80 \mathrm{~km}$ of Los Alamos

4-2. Critical Organ Dose from Human Intrusion into a Low-Leve1 Waste Area Containing TRU Wastes . 
5-1. Combined Solidified and Unsolidified Source Terms for Los Alamos TRU Waste

5-2. Grourd Water Transport Conditions at Los Alamos for Modeling

5-3. Summary Results of Modeling Transuranic Decay Chain Transport in the LoS Alamos Geohydrologic Setting for Combined Solidified and Unsolidified Alpha Waste 


\section{LOS ALAMOS LOW-LEVEL WASTE PERFORMANCE}

ASSESSMENT STATUS

\section{Compiled by}

W. J. Wenzel, W. D. Purtymun,

J. M. Dewart, and J. C. Rodgers

\section{ABSTRACT}

This report reviews the documented Los Alamos studies done to assess the containment of buried hazardous wastes. Five sections logically present the environmental studies, operational source terms, transport pathways, environmental dosimetry, and computer model development and use. This review gives a general picture of the Los Alamos solid waste disposal and liquid effluent sites and is intended for technical readers with waste management and environmental science backgrounds but without a detailed familiarization with Los Alamos.

The review begins with a wide perspective on environmental studies at Los Alamos. Hydrology, geology, and meteorology are described for the site and region. The ongoing Laboratory-wide environmental surveillance and waste management environmental studies are presented. The next section describes the waste disposal sites and summarizes the current source terms for these sites. Hazardous chemical wastes and liquid effluents are also addressed by describing the sites and canyons that are impacted. The review then focuses on the transport pathways addressed mainly in reports by Healy and Formerly Utilized Sites Remedial Action Program. Once the source terms and potential transport pathways are described, the dose assessment methods are addressed. Three major studies, the waste alternatives, Hansen and Rogers, and the Pantex Environmental Impact Statement, contributed to the current Los Alamos dose assessment methodology. Finally, the current Los Alamos groundwater, surface water, and environmental assessment models for these mesa top and canyon sites are described. 


\subsection{SITE ENVIRONMENTAL STUDIES}

\subsection{GEOHYDROLOGY AND GEOCHEMISTRY}

\section{1 .1 Setting}

Los Alamos National Laboratory is located in north-central New Mexico about $100 \mathrm{~km}(60 \mathrm{mi})$ north-northeast of Albuquerque and $40 \mathrm{~km}(25 \mathrm{mi})$ northwest of Santa Fe by air (Figure 1.1). It is situated on the Pajarito Plateau between the Jemez Mountains to the west and the Rio Grande Valley to the east. The plateau slopes eastward from an altitude of about $2400 \mathrm{~m}$ $(7800 \mathrm{ft})$ along its western margin to about $1800 \mathrm{~m}(6200 \mathrm{ft})$ to the east where it terminates above the Rio Grande at the Puye Escarpment and the rim of White Rock Canyon. The surface of the plateau is cut into numerous narrow "finger mesas" by southeast-trending intermittent streams. The dissected eastern margin of the plateau stands 90 to $300 \mathrm{~m}$ (300 to $1000 \mathrm{ft}$ ) above the Rio Grande. Most of the Laboratory development is confined on the mesa tops.

\section{1.? Historical}

The Pajarito Plateau forms a topographically high area along the western margin of the Rio Grande depression (Kelley 1952, Kelley 1954) (Figure 1.2). The depression began to form about $21 \mathrm{million}$ years ago as the result of faulting. The structural depression extends from southern Colorado, through central New Mexico, into northern Mexico. Sediments were eroded from the highland mass to the east and west and formed the basinfill sedimentary rocks of the Tesuque Formation of the Santa Fe Group (Spiegel and Baldwin 1963, Cabot 1938, Denny 1940, Galuska and Blick 1971) (Figure 1.2). These sediments occur directly over the Precambrian basement rocks with no intervening layers representing Mesozoic or Paleozoic Eras. The Santa Fe Group of Middle Miocene to Pliocene epoch was deposited by a southward flowing river in the depression (Dames and Moore Earth Science 1972). Volcanic activity that occurred during the formation of the Santa Fe Group deposited numerous basalt flows and plugs through the sediments. These basalt eruptions in the area laid down a series of basalts that 


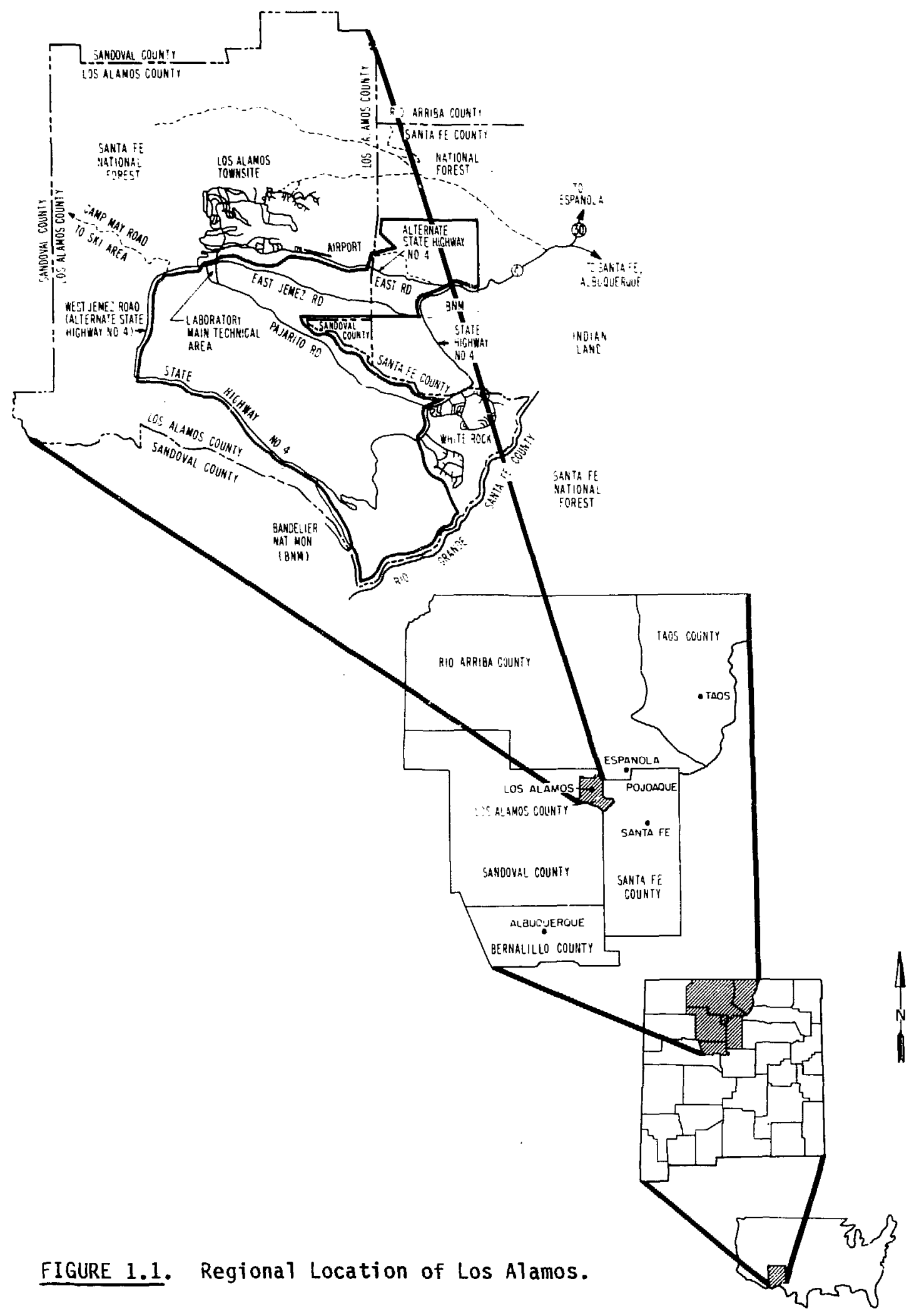




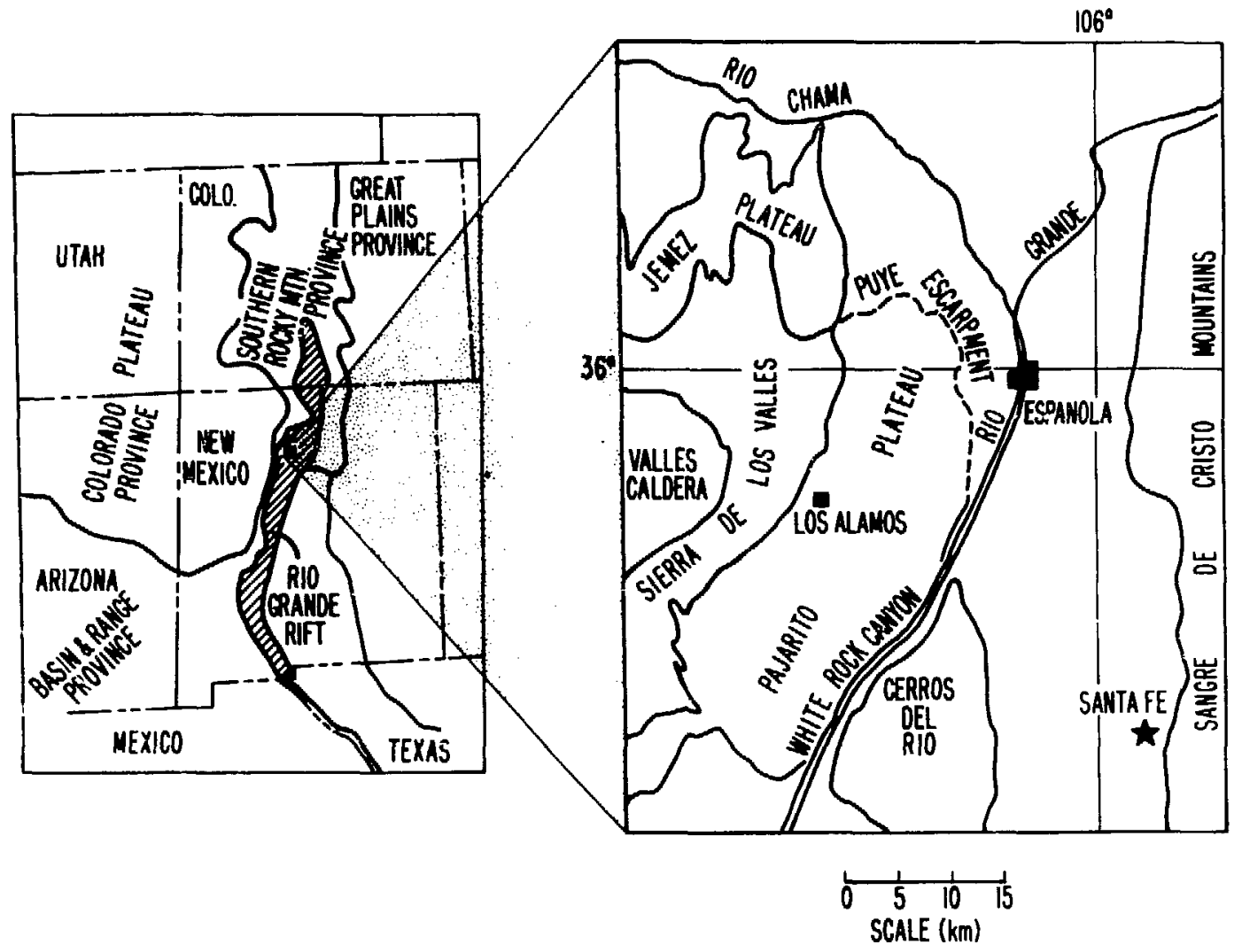

FIGURE 1.2. Physiographic Features of the Los Alamos Area.

flowed northwest into the White Rock area (east of the Laboratory) from centers southwest of Los Alamos.

The volcanic rocks of the Jemez Mountains began with a series of eruptions during the Pliocene epoch along the western margin of the depression southwest of Los Alamos. The volcanic rocks. (Polvadera Group) built a high mountain mass northward from the original vents. The volcanoes covered an area of over $2600 \mathrm{~km}^{2}$ and attained a thickness of at least $1500 \mathrm{~m}$. The volcanic activity was climaxed during the midPleistocene epoch by two gigantic pyroclastic explosions that deposited 400 $\mathrm{km}^{3}$ of rhyolite tuff and pumice (Bandelier Tuff) around the flanks of the volcanic mass. This ejection of the tuff and pumice was followed by collapse of the center of the highlands, forming a large caldera. 
Subsequent volcanic activity was the intrusion of rhyolite domes in the caldera (Smith, Bailey, and Ross 1970; Bailey, Smith, and Ross 1969). The final volcanic activity took place in the southwest part of the caldera about 42,000 years ago with the eruption of a rhyolite pumice. Onty hot springs and su?fatic activity remain in the caldera as a reminder of the volcanic activity.

The volcanic activity is a classic example of a resurgent caldera. The subcircular depression in the highland of the Jemez Mountains is from 20 to $30 \mathrm{~km}$ in diameter and from 150 to $600 \mathrm{~m}$ deep. The caldera at one time contained a lake that was later drained by headiward erosion of the Jemez River that breached the caldera walls. On the west side of the caldera, a structural dome (Redondo Peak) rises to an elevation of $3430 \mathrm{~m}$. A broad apron of dissected rhyolite tuff forms the Pajarito Plateau around the highlands of the Jemez Mountains. The easternmost part of the Jenez mountains, formed by the Tschicoma Formation adjacent to the plateau, is the Sierra de Tos Valles.

\section{1 .3 Geology}

The volcanic and sedimentary rocks cropping out near Los Alamos range in age from Tertiary to Quaternary. The geologic formations in the Los Alamos area include the Santa Fe, Polvaderà, and the Tewa Grours (Figure $1.3)$.

The Santa Fe Group includes the sedimentary and volcanic rocks that are related to the Rio Grande structural trough. They range in age from middle Miocene to Pleistocene. The base of the Santa $\mathrm{Fe}$ is above the latitic and limburgitic flows and breccias exposed in the cienega area. The youngest units of the Santa Fe are the terrace deposits and alluvia of present valleys. The Santa Fe Group formations exposed in the Los Alamos area, from the oldest to youngest, are the Tesuque Formation, the Puye Conglomerate, and the Basaltic Rocks of Chino Mesa (Figure 1.4).

The Tesuque Formation is middle Miocene to early Pliocene in age. The Tesuque Formation is composed of siltstones and sandstones with lenses of clay deposited as basii-fill sediments in the depression. It underlies the Pajarito Plateau and crops out along White Rock Canyon of the Rio Grande (Spiegel and Baldwin 1963). 


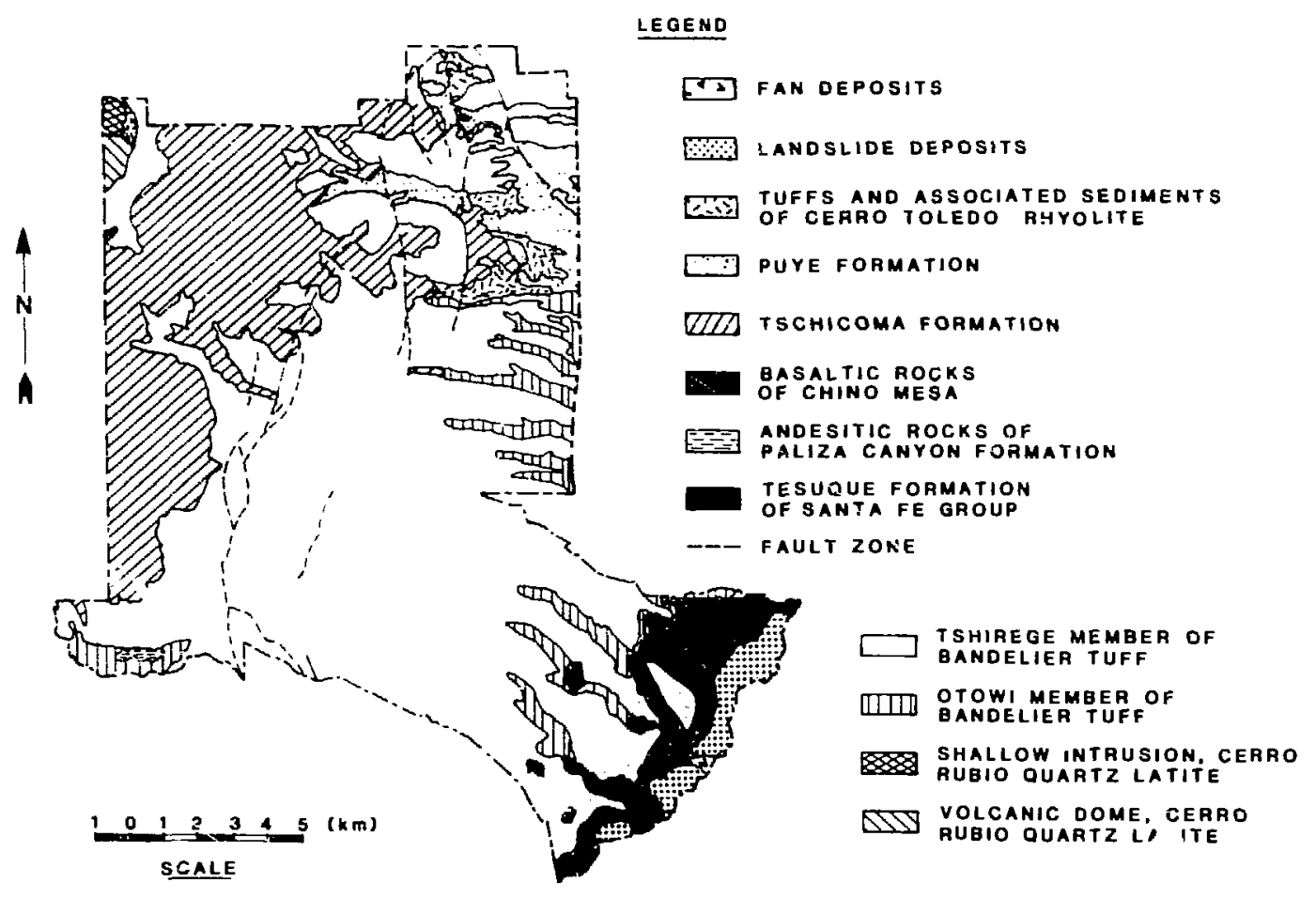

FIGURE 1.3. Geology of Los Alamos County.

The Puye Conglomerate, from the late Pliocene, consists of about $200 \mathrm{~m}$ of well-rounded pebbles, cobbles, and small boulders of quartzite, quartz, and granite with some volcanic debris in a matrix of arkosic sand (Griggs and Hem 1954). It interfingers with the Tschicoma Formation and the Basaltic Rocks of Chino Mesa beneath the Pajarito Plateau and crops out along the Rio Grande. The Puye is divided into two members, the Totavi Lentil and the Fanglomerate Members. The Puye Conglomerate was eroded from the Tschicoma Formation forming a volcanic debris over the Tesuque Formation in the central and eastern parts of the plateau. The conglomerates interfinger with basalt flows that were emplaced from the southeast. The conglomerate interfingers with the younger flows of the Tschicoma Formation to the west. The Tschicoma Formation interfingers and overlies the Tesuque along the western part of the plateau and forms the mountain mass of the Sierra de los Valles. 


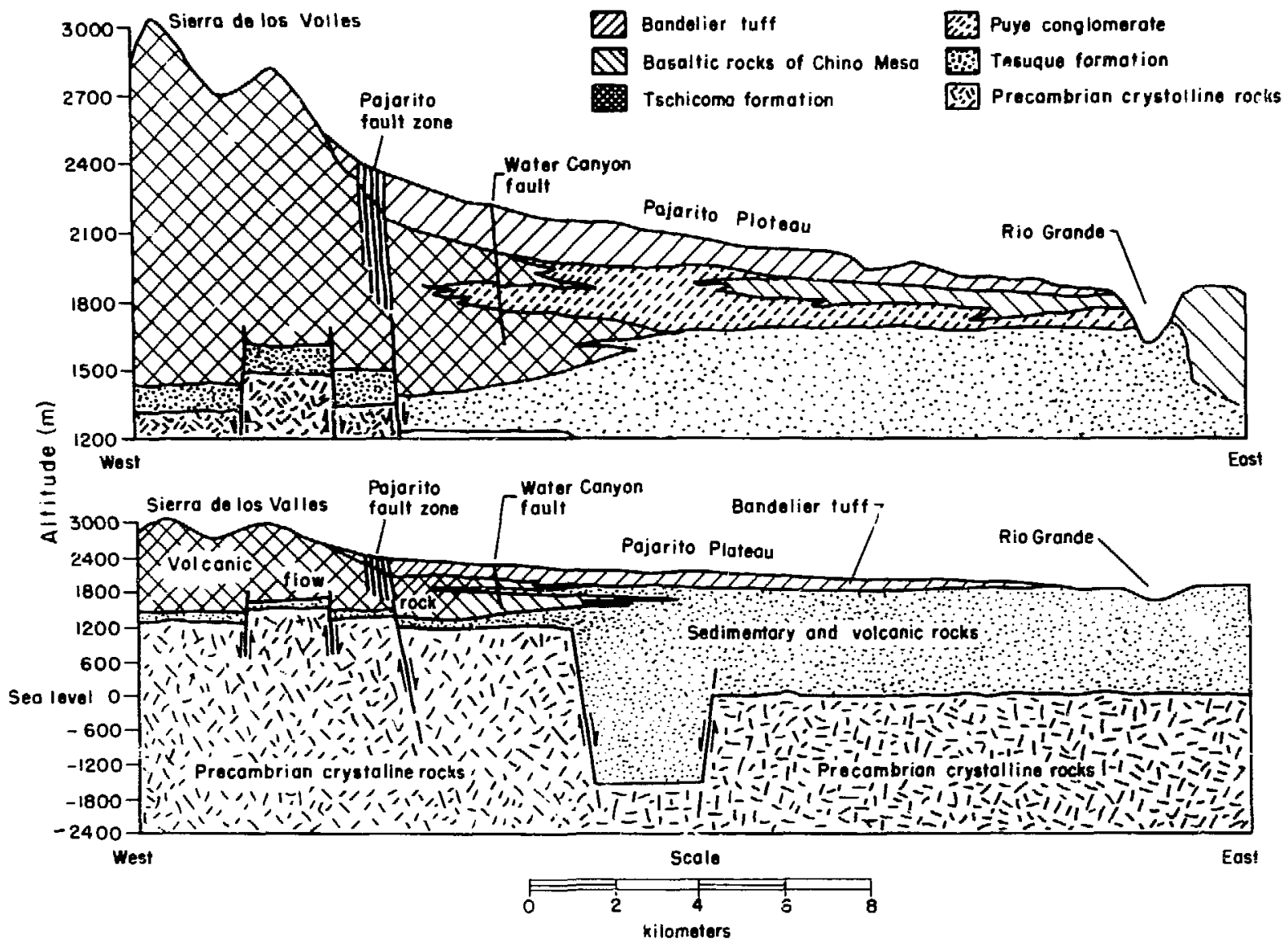

FIGURE 1.4. Geologic Stratigraphic Relationships.

Those flows that form the steep walls of White Rock Canyon and cap the high mesas to the east are the Basaltic Rocks of Chino Mesa. The sequence of flows that erupted from vents in the Cerros del Rio is greater than 390 m thick at Chino Mesa. Their age is late Pliocene to middle or late Pleistocene (Griggs and Hem 1954).

The Polvadera Group is the sequence of basaltic, andesitic, dacitic, and rhyolitic rocks, $1520 \mathrm{~m}$ thick, that form part of the central and most of the northern Jemez Mountains. The group is late Pliocene to early Pleistocene in age. Of the Polvadera formations, the Tschicoma is the only one that crops out in the Los Alamos area (Bailey, Smith, and Ross 1969).

The Tschicoma Formation consists of andesites, dacites, rhyodacites, and quartz latites. Radiometric dates of 6.7 to 3.7 million years indicate 
an age of middle to late Pliocene. West of Los Alamos in the Sierra de los Valles, the Tschicoma is greater than $790 \mathrm{~m}$ thick.

The rhyolitic tuff and rhyolite and quartz latite domes, which constitute the latest eruptive rocks of the Jemez Mountains, are in the Pleistocene Tewa Group. In the Los Alamos area, the Cerro Toledo Rhyolite and the Bandelier Tuff are the only formations of the Tewa Group that crop out (Griggs and Hem 1954).

The Cerro Toledo Rhyolite outcrops in a small area north of Los Alamos in Rendija and Guaje Canyons. Within the Valles Caldera, the rhyolites are mainly volcanic domes with some associated sediments; however, north of Los Alamos they are reworked tuff and sediments that overlie the Puye Conglomerate. They are less than $30 \mathrm{~m}$ thick.

The Bandelier Tuff caps the Pajarito Plateau. It is 80 to $320 \mathrm{~m}$ thick and is composed of two members. The lower member, the 0towi, is a massive pumiceous tuff breccia of ash-flow origin as much as $80 \mathrm{~m}$ thick that erupted from tine Toledo Caldera. The upper member, the Tshirege, is a succession of cliff-forming welded ash flows as much as $100 \mathrm{~m}$ thick that erupted from the Valles Caldera. The basal units of both members are ash falls. The basal unit of the Tshirege has a radiometric date of 1.1 million years (Bailey, Smith and Ross 1969).

The tuff laps onto the flanks of the Sierra de los Valles ard siopes gently to the east, where it terminates in cliffs or steep slopes along White Rock Canynn or as isolated outcrops above the Puye Escarpment. The surface of the plateau formed by the tuff has been dissected by southeastward-trending intermittent streams into a number of 1ong, narrow mesas.

The Bandelier Tuff is exposed along canyon walls and is covered by a thin mantle of soil on the surface of the mesas. The ash falls and ash flows are described as nonwelded, moderately welded, and welded tuff. Nonwelded tuff has a high porosity of $40 \%$ to $60 \%$ by volume, silight cohesion of glassy fragments, and crumbly fracture. Moderately welded tuff has a lesser degree of porosity, ranging from $30 \%$ to $55 \%$ by volume. It has moderate cohesion with slight deformation of glassy fragments and somewhat brittle fracture. Welded tuff has a low porosity of $15 \%$ to $40 \%$ by volume, good cohesion, a high degree of deformation by flattening of glassy fragments, and a brittle fracture. The tuff has a large range in porosity 
in each of the classifications, indicating welding is only one of several factors determining porosity (Purtymun and Koopman 1965).

The degree of welding and joirt frequency (described later) influences the physical and hydrologic characteristics of the individual ash-flow tuff units. The density ranges from less than $1 \mathrm{~g} / \mathrm{cm}^{3}$ for nonwelded tuff (pumice) to $2.2 \mathrm{~g} / \mathrm{cm}^{3}$ for welded tuff. The bearing capacities are proportional to the density of the tuff; the greater bearing capacities occur with greater density tuff. The pores in the tuff are not all interconnected; however, in general, the nonwelded tuff has a greater permeability. Hydraulic conductivities range from $3 \times 10^{-3} \mathrm{~m} /$ day for a welded tuff to as much as $2 \mathrm{~m} /$ day in a nonwelded tuff (Weir and Purtymun 196z). The natural moisture content of the tuff forming the mesas between the southeastward-trending canyons is generally less than $5 \%$ by volume.

The tuff is rhyolitic in composition and contains small rock fragments of rhyolite, latite, pumice, and crystal fragmenis of sanidine and quartz in a matrix of glass sharcis and welded ash. Dark minerals are scarce, al though traces of crystal fragments of biotite, horneblende, and pyroxene have been identified (Griggs and Hem 1954). The rhyolite and latite rock fragments are dark gray and hard and may be as much as 5 to $8 \mathrm{~cm}$ in length. Pumice is light gray and, in nonwelded units, may be as much as $15 \mathrm{~cm}$ in length.

The surface of the exposed tuff becomes "case hardened" as it is exposed to the weather. This rind forms a protective surface that resists erosion by wind and water; however, exposed pumice fragments weather rapidly, giving some of the urits a pitted surface.

Joints are common in the tuff units, dividing the tuff into irregular blocks. ine joints were formed as the ash flow cooled. Joint frequency decreases with a decrease in the degree of welding (fewer joints are found in nonwelded tuff than in welded tuff). The predominant joint sets are vertical or near vertical. Joints range from closed to as much as $5 \mathrm{~cm}$ open and may contain a clay plating or fill packed with plant roots.

The nonwelded tuff strata are found at the base of the Bandelier Tuff in the Otowi Member and lower part of the Tshirege Member. The upper part of the Tshirege Member is made up of moderately welded tuff ard a lesser thickness of welded tuff. A test hole near the center of the plateau penetrated $283 \mathrm{~m}$ of Bandelier Tuff (Weir and Purtymun 1962). Nonwelded 
tuffs in the 0towi Member and lower part of Tshirege Member make up 70\% of the thickness, whereas in the upper part of the Tshirege Member moderately welded tuffs make up $20 \%$ and welded tuffs the remaining $10 \%$. Almost all of the Laboratory facilities are sited on the moderately welded or welded ash flow.

\section{$1.1 .4 \underline{\text { Soil s }}$}

An intensive soil survey of about $79 \%$ of the $280 \mathrm{~km}^{2}$ of Los Alamos County, including all of the Laboratory site within the county, was completed by a joint Laboratory and Soil Conservation Service project. General and detailed descriptions were developed for each of 61 soilmapping units including information on soil color, texture, structure, consistency, clay films, size distributions, permeability depth, hydrologic properties, porer, $\mathrm{pH}$, and soil horizon boundaries (Nyhan et al. 1978).

\subsubsection{Sei smology}

The Los Alamos area lies within the Rio Grande depression, which was formed by a complex series of faults. Adjustments that result in seismic activity are still taking place along the faults within the depression.

The faults trend north-south in the Los Alamos area, displacing the Bandelier Tuff (Figure 1.j). The faults constitute zones of weakness in the earth's crust. Reactivation or movement along the faults could cause surface displacement. Laboratory facilities are not located across any known fault zones. In the vicinity of Los Aiamos, the Pajarito Fault is downthrown to the east with a maximum displacement of $120 \mathrm{~m}$; the Guaje Mountain Fault is downthrown to the west with a maximum displacement of 16 iii; and the Water Canyon Fault is downthrown to the east with a maximum displacement of $9 \mathrm{~m}$.

A study of seismic risk in the Los Alamos area was made based on seismological and historical records. The data for all shocks occurring within $111 \mathrm{~km}$ of Los Alamos included 1) historical noninstrumented reports of earthquakes before 1962 and 2) geologic evidence (faulting) of 


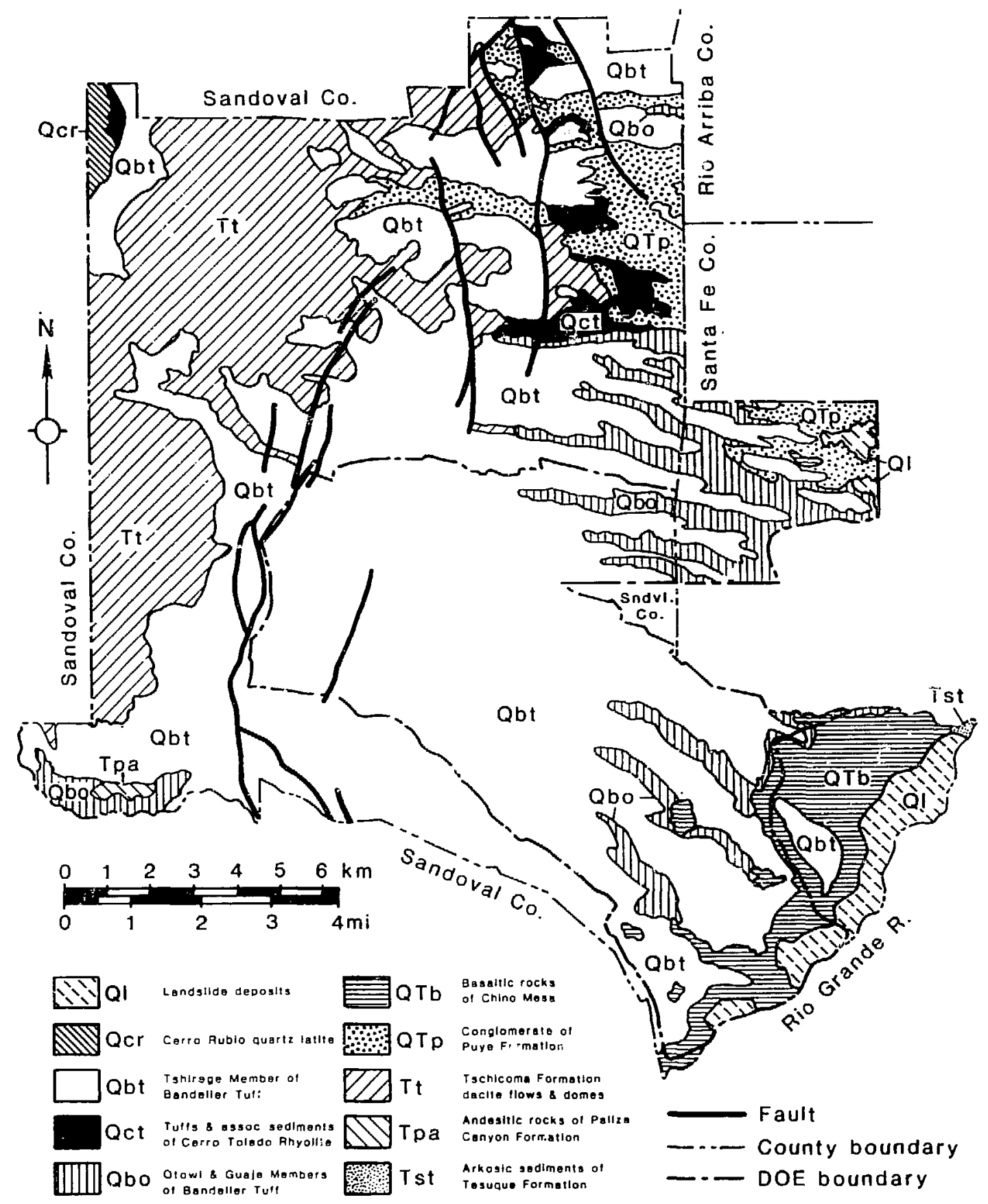

FIGURE 1.5. General Geology of Los Alamos County and a Part of Adjacent Santa Fe County. 
seismicity. Magnitudes were inferred from the historical reports that, of necessity, related to effects (intensity).

The strongest earthquake to occur within the region of study during the 100-year period, 1872 to 1972, had a probable magnitude of 5.5 on the Richter scale. Estimates of the strongest shock to occur in a 100-year period, based on extrapolation of the earthquake frequency/magnitude relation, range from 3.9 to 5.4. This historical study concludes that the Los Alamos area is subject to an earthquake of magnitude 5.5 once every 100 years somewhere within the Rio Grande depression from Albuquerque northward about $200 \mathrm{~km}$ (Sanford 1976).

Another evaluation of seismic risk in the Los Alamos area was made based on geologic evidence (Budding and Purtymun 1976). The studies of fault characteristics yielded a theoretical interpretation of likely magnitude and frequency of shocks produced from rupture along faults or in fault zones on the basis of the length of the fault, offset or throw of the fault, and age of stratigraphic units broken by the faults. The major faults studied were the Pajarito, Los Alamos, Guaje Mountain, and Water Canyon Faults. A11 are north- to south-trending faults, breaking the upper Tshirege Memuer of the Bandelier Tuff along the western edge of the Pajarito Plateau. Seismicity of the area indicates that magnitude-6.7 earthquakes occurred at approximately 8270-year intervals or that nagnitude-4.8 earthquakes occurred at 100-year intervais (Budding and Purtymun 1976).

The seismicity of the Los Alamos region is estimated by the geologic evaluation to be one mágnitude-5 earthquake per 100 years, which is in good agreement with the historical records. The seismicity of this section of the Rio Grande depression is less than that of the Albuquerque-Socorro section (with an est'ikated maximum magnitude shock of 6 in a 100-year interval) and substaltially less than that of an equivalent area in Southern Salifornia (Sanford 1976).

The Rio Grande, the master stream of the region, drains more than $37,000 \mathrm{~km}^{2}$ in northern New Mexico and Colorado. The average discharge of the Rio Grande at the Otowi Bridge gauging station was about $1 \mathrm{~km}^{3} / \mathrm{yr}$ for the 1955 to 1974 period. Daily suspended sediments discharged at the station for the period 1947-1974 ranged from $2.7 \times 10^{3} \mathrm{~kg}$ to $3.4 \times 10^{8} \mathrm{~kg}$. 
Surface stream tributaries to the Rio Grande within about $100 \mathrm{~km}$ of Los Alamos are the Chama, Caliente, Santa Cruz, Nambe, and Tesuque Rivers to the north and east; the Jemez and San Antonio Creeks to the west; and the Santa Fe and Galisteo Rivers to the south (Figure 1.6) (Lansford 1973). Flood control, irrigation, and water supply reservoirs include Abiquiu on the Chama River; Santa Cruz on the Santa Cruz River; Two-Mile, Nichols, and McClure on the Santa Fe River; Galisteo on the Galisteo River; Jemez on the Jemez River; and Cochiti on the Rio Grande.

Cochiti is a relatively new reservoir, which began filling in 1976. It is designed to provide flood control, sediment retention, recreation, and fishery development. The dam is $9 \mathrm{~km}$ long, earthfilled, and located on the Rio Grande about $15 \mathrm{~km}$ from the southernmost point of the Laboratory boundary. The permanent pool, $5 \times 106 \mathrm{~m}^{2}$ surface area, extends upstream some $12 \mathrm{~km}$, reaching a point about $5 \mathrm{~km}$ from the southernmost point of the Laboratory boundary, and has a capacity of nearly $62 \times 10^{6} \mathrm{~m}^{3}$. The flood-control pool extends upstream to the 0towi Bridge with a total volume of $750 \times 10^{6} \mathrm{~m}^{3}$.

Essentially all downstream flow passes through the reservoir. Flood flows are temporarily stored and released at safe rates. The sedimenttrapping function of the dam is expected to trap at least $90 \%$ of the sediments carried by the Rio Grande. Approximately $6.2 \times 10^{6} \mathrm{~m}^{3}$ per year is lost to evaporation from the permanent pool. The reservoir provides for boating and fishing.

No municipal water supplies are taken directly from the Rio Grande downstream from the Laboratory in New Mexico. Irrigation water is taken from the Rio Grande downstream from the Laboratory at numerous diversions starting below Cochiti Dam.

The quality of surface waters in the upper Rio Grande Basin is generally good. The bacterial and chemical quality of all streams, with the exception of a reach of the Rio Grande between Española and Otowi Bridge, is considerably better than that required by the New Mexico State Water Quality Control Commission stream standards. The poor quality beloy Espanola to 0towi Bridge is attributed to the population concentration in the Espanola Valley and inadequate sewage treatment (Stephen R. Flancs and Associates 1976). This reach is upstream of Los Alamos. 


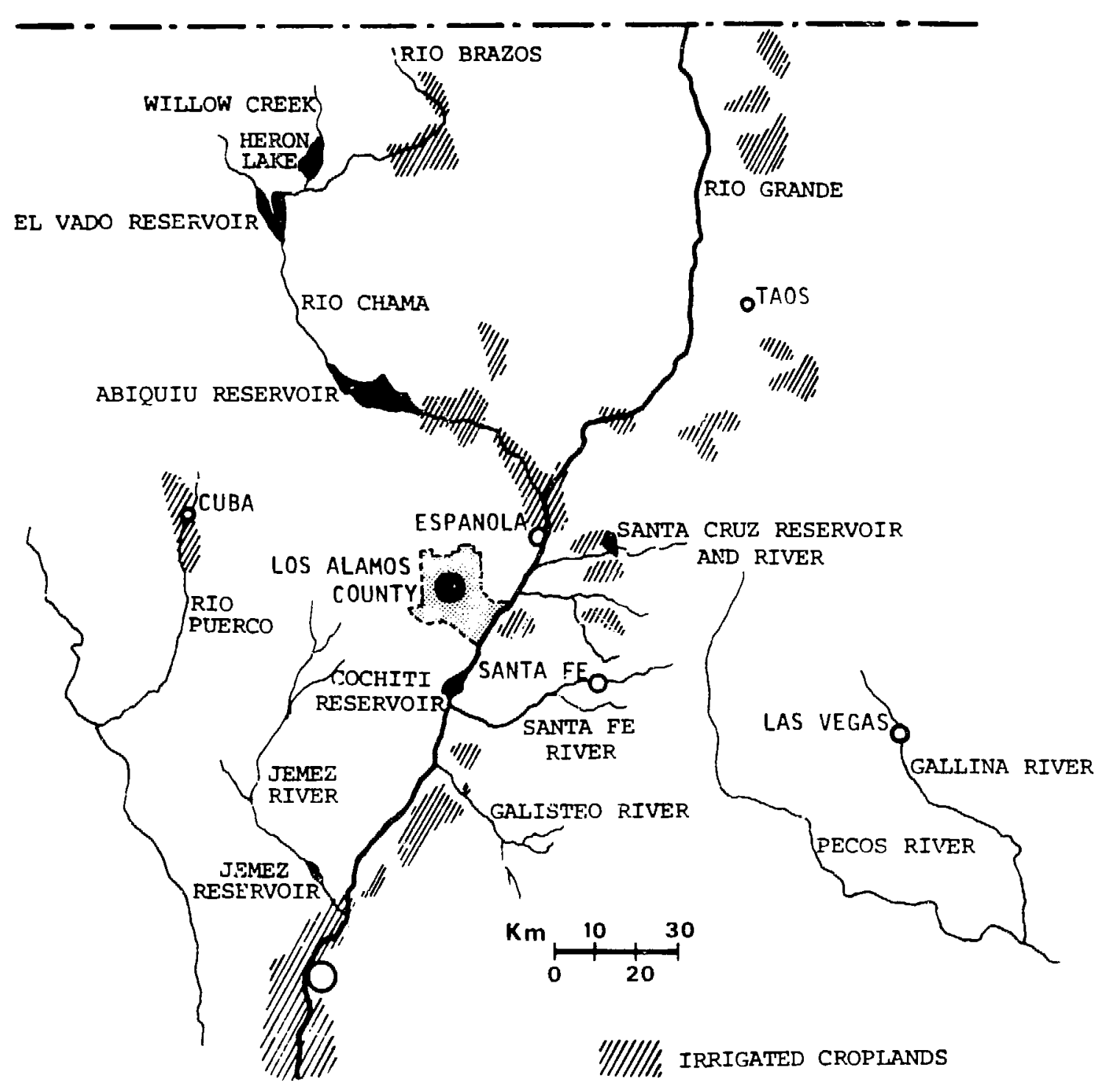

FIGURE 1.6. Regional Surface Waters. 
In the Los Alamos area, intermittent streams flow in canyons cut into the Pajarito Plateau. Perennial flow to the Rio Grande occurs in the Rio de los Frijoles to the south of the Laboratory and the Santa Clara to the north. Springs between $2400-$ and $2700-m$ elevation on the slopes of the Sierra de los Valles supply base flow throughout the year to the upper reaches of Guaje, Los Alamos, Pajarito, and Water Canyons, and Canyion dal Valle. These springs discharge water Tschicoma Formation at rates from $/$ to $530 \mathrm{l} / \mathrm{min}$. The volume of flow from the springs is insufficient to maintain surface flow within more than the western third of the canyons before it is depleted by evaporation, tmansiration, and infiltration into the underlying alluvium.

Sixteen drainage areas, with a total area of $212 \mathrm{~km}^{2}$, pass through or originate within the Laboratory boundaries (Figure 1.7) (Schiager and Apt 1974). Stream flow in thase canyons is intermittent. Runoff from heavy thunderstorms or unusually heavy snowmelt will reach the Rio Grande. Four Canyons--Pueblo, Los Alamos, Pajarito, and Water--have areas greater than $20 \mathrm{~km}^{2}$. Ancho Canyon has $17 \mathrm{~km}^{2}$, and ail the rest have less than 10 $\mathrm{xm}^{2}$. Theoretical flood frequency and maximum discharge in 10 of the well-defined channels of the 16 drainage areas range from $1.1 \mathrm{~m}^{3} / \mathrm{s}$ for a 2-year frequency to $21 \mathrm{~m} 3 / \mathrm{s}$ for a 50 -year frequency. Flooding does not pose a problem in the Los Alamos area (Schiager and Apt 1974). Highways are sometimes closed for an hour when ilash floods in canyons cross the pavemerit. Neanly all community and Laboratory structures are located on the mesa tops, which drain rapidly into the deep canyons.

Sanitary sewage effluents from both the townsite and the Laboratory are released into Pueblo and Sandia Canyons in sufficient volume to saturate the alluvium and maintain surface flows for a few tenths of a kilometer. Mortandad Canyon contains a small perennial stream maintained for about $1.5 \mathrm{~km}$ by effluents from Laboratory cooling towers and an industrial waste-treatmeni plant.

Ground water (subsurface water) occurs as perched water in alluvium and basalts and, in the zone of saturation, in sediments of the main aquifer of the Los Alamos area (Cushman 1965, Griggs and Hem 1954). The relationship of the occurrence of ground water to lithologic units is shown in Figure 1.8 . 


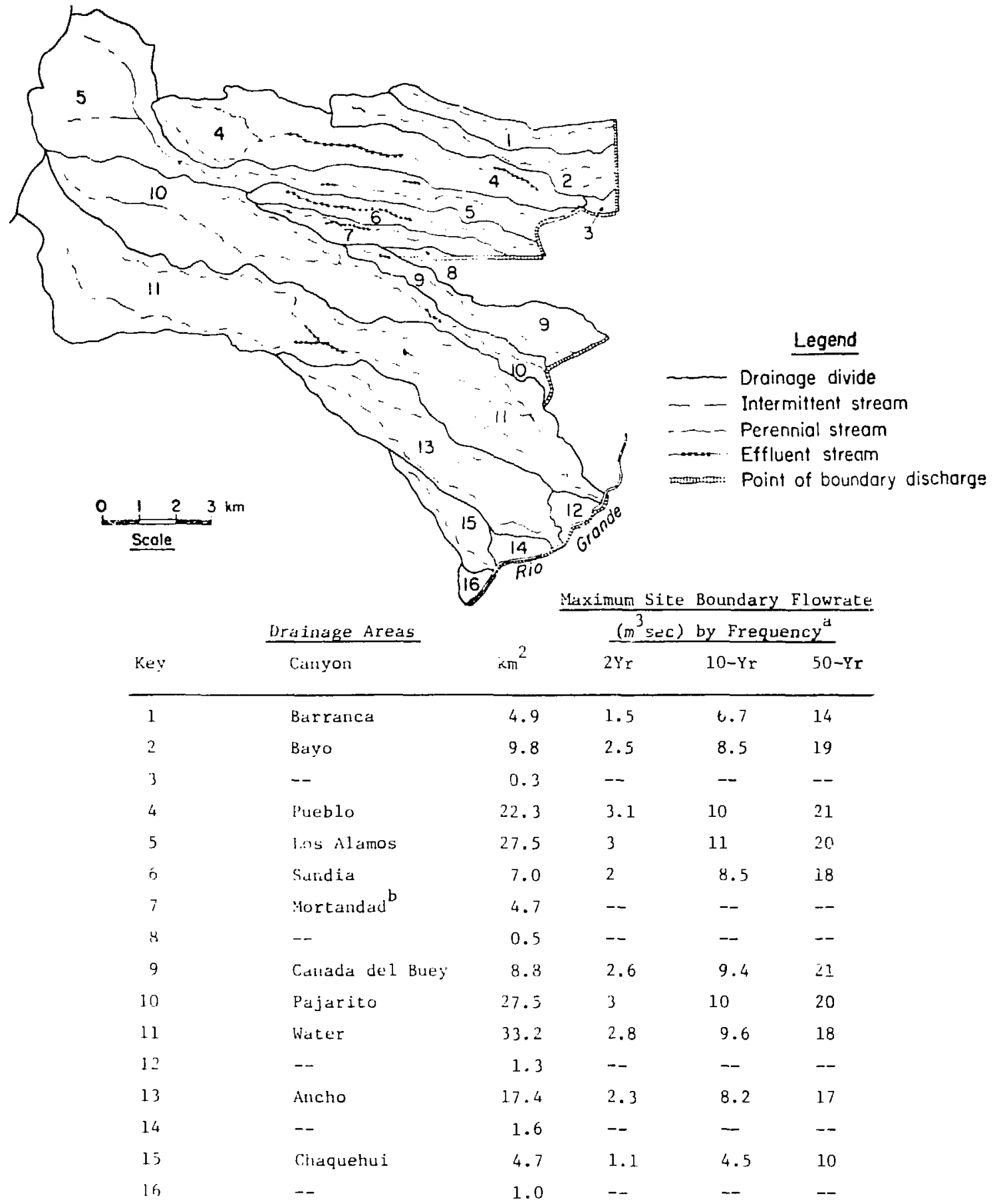

(a) Theoretical estimates (made for areas with reasonably defined channels) using nomographic methods. A particular flow can be expected to be equalled or exceeded in the time perlod. Alternatively, the 2-, 10-, and 50-year events can be interpreted to have probabilities of occurrence in a given year of $0.5,0.1$, and 0.02 , respectlvely.

(b) Mortandad Canyon is the only major canyon for which no run-off is predicted, owing to lack of a main channel in the lower portions.

\section{FIGURE 1.7. Surface Drainage Areas Crossing or Originating on Los Alamos Site.}




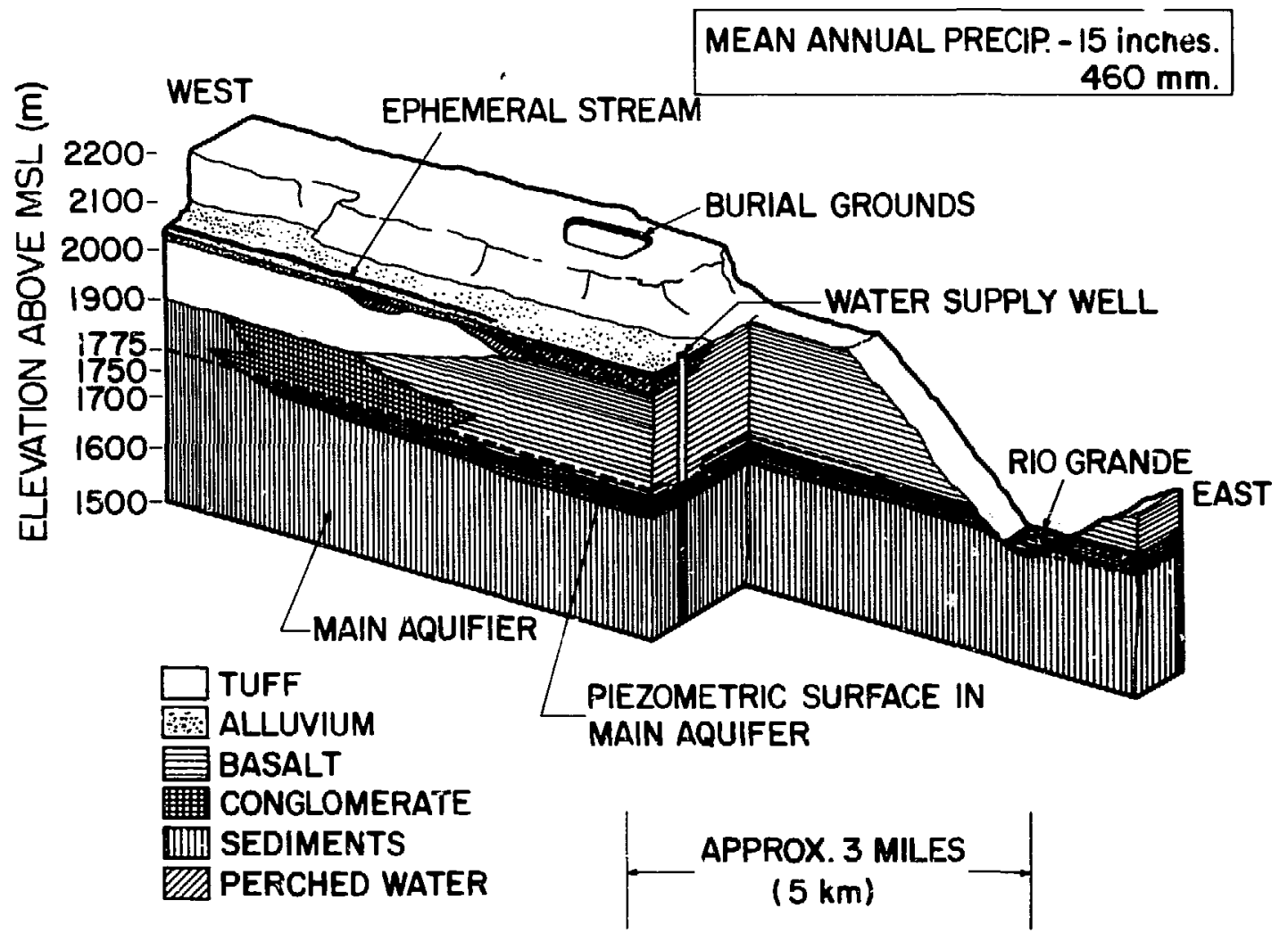

FIGJRE 1.8. Hydrological Cross Section.

Water from rainfall and snowmelt infiltrates the surface, providing moisture to the soil zone and supporting plant growth. This moisture does not move more than a few meters into the tuff on the tops of the mesas (A.brahams, Baltz and Purtymun 1962). The tuff, as a result, has a low moisture content (generally $<5 \%$ by weight)--too low even for most plants to extract water (Purtymun and Kennedy 1971).

Two types of alluvium have developed in the stream channel. Drainage areas heading on the mountain flanks are made up of sand, gravels, cobbles, and boulders derived from the Tschicoma Formation and Bandelier Tuff. Drainage heading on the plateau contains only sands, gravels, and cobbles derived from the Bandelier Tuff. The alluvium is quite permeable, allowing rapid infiltration of rainfall and streamflow. The alluvium generally 
overlies the less permeable tuff. Water infiltrates downward in the alluvium until its movement is held back by the tuff. This results in the build-up of a ground water perched within the alluvium (Abrahams, Weir and Purtymun 1961). The perched water moves downgradient in the alluvium at a rate from 1 to $20 \mathrm{~m} /$ day. Hydraulic conductivity of the alluvium ranges from $141 \mathrm{~m} /$ day for a sand aquifer to $50 \mathrm{~m} /$ day for a silty sand aquifer (Purtymun 1974).

As water perched in the alluvium moves down the gradient, it is lost by evaporation and transpiration through plants and infiltration into underlying tuff. Vecetation is lush where surface or perched water in the alluvium is present. Hater moving from the alluvium into the volcanic debris in the lower reach of Pueblo Canyon and the midreach of Los Alamos Canyon recharges a local body of perched water within the Basaltic Rocks of Chino Mesa. Water from this perched aquifer discharges at the base of the basalt in Los Aiamos Canyon west of the Rio Grande. Transit time in the aquifer is about $3.8 \mathrm{~m} /$ day with a hydraulic conductivity of $114 \mathrm{~m} /$ day (Weir et a1. 1963).

Perched water is not found in the tuff, volcanic sediments, or basalts above the main aquifer in the centrai and western portions of the plateau. Test holes in these areas penetrated numerous rock units that had the potential of perching water above the main aquifer. The absence of wate: in these test holes indicates that the infiltration of surface water through the alluvium and the tuff is limited. Age dating of water from the main aquiter further supports :he inference of insignificant infiltration of surface water through the alluvium and tuff to the main aquifer.

The main aquifer in the Los Alamos area is located within the Tesuque Formation beneath the entire plateau and Rio Grande Valley. The lower part of the Puye Conglomerate as well as the Tesuque Formation is within the main aquifer beneath the central and western portions of the plateau (Purtymun and Cooper 1969). The depths to water below the mesa tops range from about $360 \mathrm{~m}$ along the western mirgin of the plateau to about $180 \mathrm{~m}$ along the eastern part of the plateau. The thickness of potable water in the aquifer is estimated to be at least $1200 \mathrm{~m}$ (Kelly 1974). The hydraulic gradient of the aquifer ave:ages about $11 \mathrm{~m} / \mathrm{km}$ within the Puye Conglomerate but increases to about $20 \mathrm{~m} / \mathrm{km}$ along the eastern edge of the plateau as the water in the aquifer enters the less permeable sediments of 
the Tesuque Formation (Figure 1.9). The average movement rate within the aquifer is about $0.3 \mathrm{~m} /$ day toward the Rio Grande (Theis and Conover 1962).

The hydraulir conductivity and transinissivity is different for various rock units within the main aquifer. Aquifer tests in wells penetrating the Puye Conglomerate indicated hydraulic conductivities ranging from less than $1 \mathrm{~m} /$ day to $13 \mathrm{~m} /$ day. Tests in a well penetrating the Tschicoma Formation indicated a hydraulic conductivity less than $1 \mathrm{~m} /$ day (Weir et al. 1963 ). Supply wells in the Los Alamos Field penetrating sediments of the Tesuque Formation have an average transmissivity of $198 \mathrm{~m}^{2} /$ day, with an average hydraulic conductivity of less than $1 \mathrm{~m} /$ day. The wells in the Guaje Field, which penetrate basalts interbedded with sediments in the Tesuque Formation, have an average transmissivity of about $186 \mathrm{~m}^{2} /$ day, $k i$ th an average hydräilic conauctivity of about $1 \mathrm{~m} /$ day (Cushman 1965). Supply

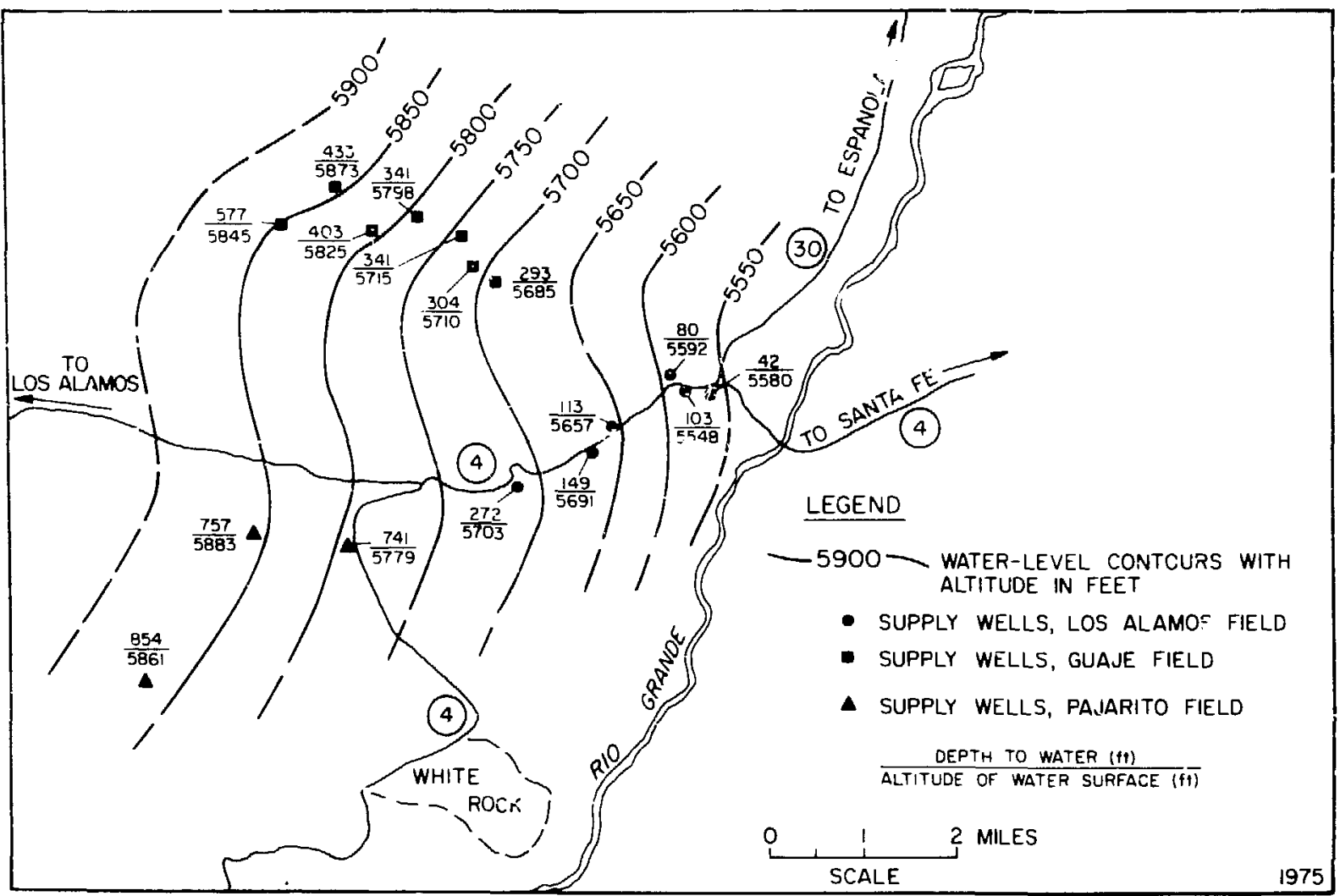

FIGURE 1.9. Generalized Contours on the Surface of the Main Aquifer. 
wells in the Pajarito Well Field penetrated basalts interbedded with sediments in the Puye Conglomerate and the Tesuque Formation. The transmissivities ranged from 500 to $4000 \mathrm{~m}^{2} /$ day, with hydraulic conductivities ranging from about 1 to $200 \mathrm{~m} /$ day (Cooper, Purtymun and John 1966; Purtymun 1967). The aquifer is under water table conditions in the western portion of the plateau. Along the eastern margins, the aquifer is artesian.

The major recharge area for the deep aquifer is in the intermountain basins formed by the Valles Caldera. The saturated sediments and volcanics in the basin are highly permeable and recharge the main aquifer in sediments of the Tesuque Formation and Puye Conglomerate (Purtymun and Johansen 1974). Minor amounts of recharge may occur in the deep canyons containing perennial streams on the flanks of the mountains.

The movement of water in the main aquifer is eastward toward the Rio Grande, where a part is discharged through springs and seeps into the river. It is estimated that the $18.4-\mathrm{km}$ reach through White Rock Canyon below 0towi Bridge receives a discharge from the aquifer of 5.3 to $6.8 \therefore 10^{6} \mathrm{~m}^{3}$ annually (Purtymun 1966).

\subsubsection{Geochemistry}

Complementary to research in hydrologic mechanisms of contaminant transport is the research that deals with geochemical mechanisms. If the hydrology can ba controlled at a waste disposal site, it is not critical to understand all chemical reactions that could occur between contaminant species and the surrounding geologic media. However, it is not possible at this stage of waste disposal site technology development to ensure complete control of the hydrology for long periods. Another general area of concern that necessitates an understanding of the geochemistry as well as the hydrology is liquid waste streams, which although treated, contain trace contaminants when released to the environment. This concern has prompted research toward the mobility of waste actinides in a shallow aquifer of a Los Alamos canyon.

Treated radioactive waste effluent at Los $A$ lamos has been released to the environment in Mortandad Canyon since 1963. A study has been initiated to investigate $\left.{ }_{-1}\right)$ he relative mobilities of the actinides in the shallow 
aquifer of Mortandad Canyon and 2) the inf?uence of physicochemical characteristics of those mobilities (Polzer, Essington, Cokal and Nelson 1984). The study extends the understanding of processes controlling actinide mobility, whicli provides a broader technical basis for predicting and controlling actinide mobility in the environment. Some important results follow:

1. Mobility is inversely related to concentration ratio $\left(K_{n}\right)$. Based on that reiationship, the mobility of americium $(\mathrm{Am})$ and plutonium ( $\mathrm{Pu})$ is similar in the upper reaches of tile canyon $\left(K_{D}=10^{4} \mathrm{~m} / \mathrm{g}\right)$. However, the mobility of americium $\left(K_{D}=102 \mathrm{~m} / \mathrm{g}\right)$ is much greater than that for plutonium $\left(K_{D}=104 \mathrm{~m} / / \mathrm{g}\right)$ in the lower reaches of the canyon.

2. The distribution of charges associated with plutonium is relatively constant throughout the canyon; $>90 \%$, $<10 \%$, and $<2 \%$ of the plutonium behave as neutral, anionic, and cationic species, respectively. In the upper reaches of the canyon, americium appears to have a charge distribution similar to plutonium. However, in the lower reaches, the proportion of anionic species increases to about $40 \%$ from about $10 \%$ in the upper reaches of the canyon.

3. Approximately $87 \%$ of the plutonium and $27 \%$ of the americium in the aquifer water were associated with a colloidai size fraction of $25 \mathrm{~nm}$ to $450 \mathrm{~nm}$. About 7\% of the plutonium and $61 \%$ of the americium were associated with the <10-kMW (molecular-weight) size fraction.

4. Plutonium and americium tracers did not equilibrate readily with the ambient plutonium and americium. For example, only $16 \%$ of the plutonium tracer was associated with the 25-nm to 450-nm size fraction, and only $28 \%$ of the americium tracer was associated with the $<10-k M W$ size fraction.

5. The ambient americium in the $<10 \mathrm{kMW}$ size fraction adsorbed to sediment to a lesser extent then did plutonium and the tracer americium.

The above results suggest that plutonium is associated with mobile colloidal material and americium is associated with both mobile colloidal and low-molecular-weight materials. Neither species equilibrates readily with its aqueous environment. As the effiuent moves through the aquifer, the colloidal material is removed from "solution." In the lower reaches of 
the canyon, the low-molecular-weight americium complex becomes the predominant americium species and is not adsorbed readily by sediment.

\subsection{METEOROLOGY}

\subsubsection{General Climatology}

Los Alamos has i semiarid continental mountain climate, characterized by moderate seasonal temperatures, warm-season convective rain showers, and winter migratory storms. A summary of average temperatures and precipitation from 1951 to 1980 recorded at the airport (1951-1960), the Administration Building TA-3 (1961-1967), a.id the Occupational Health Laboratory (OHL) TA-59 (1968 to present) is presented in Table 1-1 [Figure 1.10 for Technical Area (TA) locations].

The annual average precipitation is approximateiy $45 \mathrm{~cm}$ (18 in.). Sixty per cent of the annual precipitation falls during thunderstorms from May through October. Peak shower activity occurs in July and August when

TABLE 1-1. Temperature and Precipitation Averages 1951-1980 Temperature

\begin{tabular}{|c|c|c|c|c|c|c|}
\hline \multirow[b]{2}{*}{ Month } & \multicolumn{2}{|c|}{ Daily Max } & \multicolumn{2}{|c|}{ Daily Min } & \multicolumn{2}{|c|}{ Precipitation } \\
\hline & $\left({ }^{\circ} \mathrm{C}\right)$ & $\left({ }^{\circ} \mathrm{F}\right)$ & $\left({ }^{\circ} \mathrm{C}\right)$ & $\left({ }^{\circ} \mathrm{F}\right)$ & $(\mathrm{mm})$ & (in.) \\
\hline Jan & 4.3 & 39.7 & -7.5 & 18.5 & 21.5 & 0.85 \\
\hline Feb & 6.1 & 43.0 & -5.8 & 21.5 & 17.3 & 0.68 \\
\hline Mar & 9.3 & 48.7 & $-\hat{3} .0$ & 26.5 & 25.5 & 1.01 \\
\hline Apr & 14.2 & 57.6 & 1.0 & 33.7 & 21.9 & 0.86 \\
\hline May & 19.4 & 67.0 & 6.0 & 42.8 & 28.7 & 1.13 \\
\hline Jun & 25.4 & 77.8 & 11.3 & 52.4 & 28.5 & 1.12 \\
\hline Jul & 26.9 & 80.4 & 13.4 & 56.1 & 80.7 & 3.18 \\
\hline Aug & 25.2 & 77.4 & 12.4 & 54.3 & 99.8 & 3.93 \\
\hline Sep & 22.3 & 72.1 & 9.1 & 48.4 & 41.4 & 1.63 \\
\hline Oct & 16.7 & 62.0 & 3.7 & 38.7 & 38.7 & 1.52 \\
\hline Nov & 9.3 & 48.7 & -2.7 & 27.1 & 24.4 & 0.96 \\
\hline Dec & 5.2 & 41.4 & -6.5 & 20.3 & 24.4 & 0.96 \\
\hline Annual & 15.4 & 59.6 & 2.6 & 36.7 & 452.8 & 17.83 \\
\hline
\end{tabular}




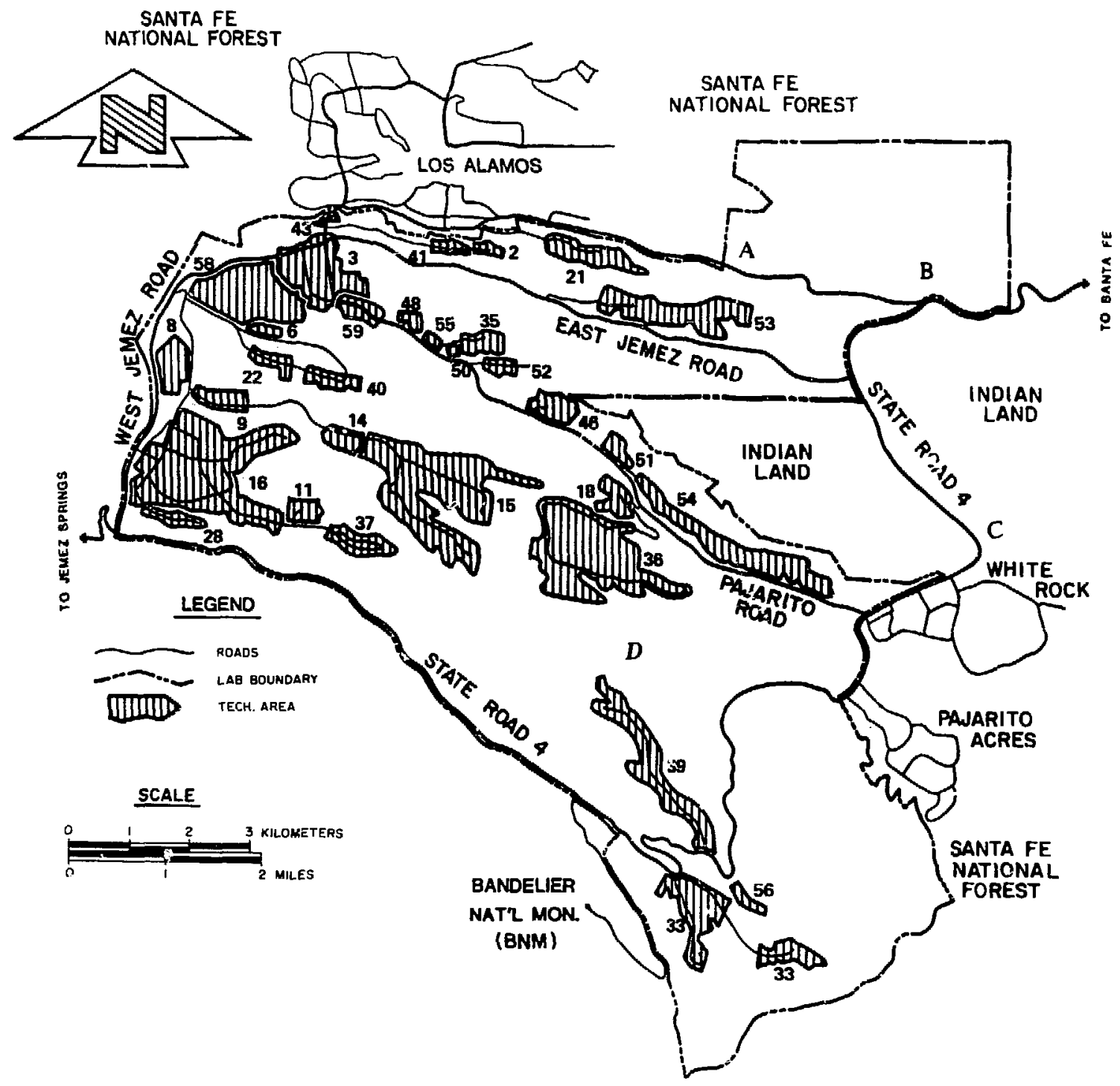

FIGURE 1.10. Technical Area (TA) and Weather Station (A-D) Locations.

rainfall of at least $2.5 \mathrm{~mm}$ (0.1 in.) will occur on 1 day out of 4 . Winter precipitation falls primarily as snow, with annual accumulations of about $1.3 \mathrm{~m}(51 \mathrm{iin.})$

Summers are. generally sunny with moderately warm days and 6001 nights. Average daily summer temperatures range from $11^{\circ} \mathrm{C}\left(52^{\circ} \mathrm{F}\right)$ to $27^{\circ} \mathrm{C}\left(80^{\circ} \mathrm{F}\right)$ with 1 or 2 days per summer reaching $32^{\circ} \mathrm{C}\left(90^{\circ} \mathrm{F}\right)$. During the wintertime, 
average temperatures range from $-7^{\circ} \mathrm{C}\left(19^{\circ} \mathrm{F}\right)$ to $4^{\circ} \mathrm{C}\left(40^{\circ} \mathrm{F}\right)$. The lowest temperature recorded for Los Alamos was $-27.8^{\circ} \mathrm{C}\left(-18^{\circ} \mathrm{F}\right)$ in January 1963.

Monthly relative humidity averages vary from 37 to 53\%. The highest averages are observeri during the summer thunderstorm season in July and August. The driest time of the year is the late spring and early sumner.

Prevailing winds at Los Alamos are from the northwest through the south with an average speed of 2.5 to $3 \mathrm{~m} / \mathrm{s}$ ( 6 to $7 \mathrm{mph}$ ). When large-scale pressure gradients are weak, a distinct diurnal-slope wind cycle occurs due to the complex terrain of the area. The cycle consists of a light southeasterly upslope wind during the morning hours and light west-tonorthwest drainage flow at night. Severe weather phenomena, such as tornados and hurricanes, have not been observed in Los Alamos.

\subsubsection{Precipitation}

Precipitation is recorded at a number of locations at the Laboratory to cover the complex terrain of the Pajarito Plateau. The annual totals for 1984 at these measurement sites are presented in Table 1-2. The sites at higher elevations, closer to the Jemez Mountains, consistently measure the greatest precipitation totals.

As shown in Table 1-1, the heaviest precipitation falls during July and August. Early spring and late autumn can also account for a large portion of the annual precipitation, as snowstorms during these months are often very wet. For example, $76.7 \mathrm{~mm}$ (3.02 in.) and $81.5 \mathrm{~mm}$ (3.21 in.) of precipitation were recorded at OHL in 0ctober and December 1984, representing the tenth wettest 0ctober and the wettest December on record. Seventy percent of this precipitation fell as snow.

Annual precipitation measurements for Los Alamos are presented in Figure 1.11. The data range from $142 \mathrm{~mm}(5.6 \mathrm{in.})$ in 1956 to $770 \mathrm{~mm}(30.3$ in.) in 1941. Precipitation data for 1921 are missing.

Return-period rainfall estimates have been made for Los Alamos (Table 1-3) by using lata presented in the National Atmospheric and 0ceanographic Administration (NOAA) Atlas-2 (Miller 1973). The maximum predicted rainfall for a specified time (15 min to annual) and the expected return 


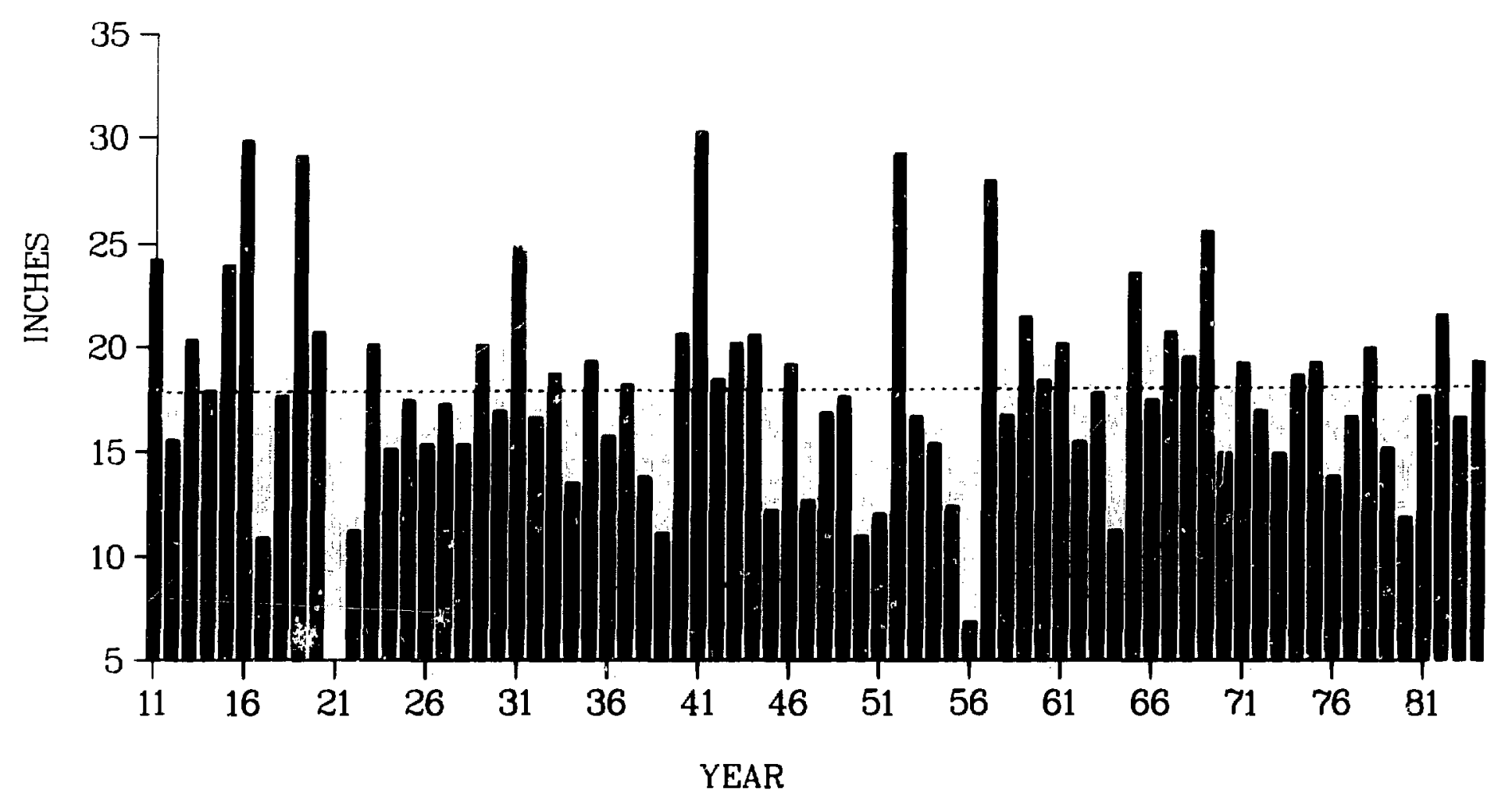

FIGURE 1.11. Annual Precipitation Amounts for Los Alamos. 
TABLE 1-2. 1984 Precipitation Totals

\begin{tabular}{|c|c|c|c|c|}
\hline \multirow[b]{2}{*}{ Site } & \multirow[b]{2}{*}{ Location (a) } & \multirow{2}{*}{ (m) } & \multicolumn{2}{|c|}{ 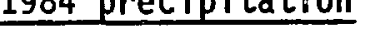 } \\
\hline & & & $(\mathrm{mm})$ & $(i n)$ \\
\hline S-Site & $T A-16$ & 2338 & 557.3 & 21.94 \\
\hline $\mathrm{OHL}$ & $T A-59$ & 2248 & 492.5 & 19.39 \\
\hline East Gate & "A" & 2140 & 364.0 & 14.33 \\
\hline Area $G$ & $T A-54$ & 2039 & 369.3 & $14.54^{(b)}$ \\
\hline White Rock-Y & "B" & 1944 & 329.4 & 12.97 \\
\hline White Rock & "C" & 1944 & 320.0 & 12.60 \\
\hline
\end{tabular}

(a) See Figure 1-10 for locations.

(b) The Area $G$ data for 1984 were estimated because of instrument problems.

TABLE 1-3. Precipitation Frequency Estimates for Los Alamos, New Mexico $\left(106^{\circ}, 19^{\prime} \mathrm{N}\right.$, Elev $\left.=7410 \mathrm{ft}\right)$ (Miller 1973)

Return

Period

$\operatorname{Tr} \quad 15-\min \quad 30-\min \quad 60 \cdot \min \quad 2-h \quad 3-h \quad 6-h \quad 24-h \quad$ Annual $^{(a)}$

$\frac{\text { (years) }}{2} \frac{P_{15}}{0.56} \frac{P_{30}}{0.77} \frac{P_{60}}{0.98} \frac{P_{2}}{1.11} \frac{P_{3}}{1.20} \frac{P_{6}}{1.36} \frac{P_{24}}{1.76} \frac{P_{A}}{17.99}$

$\begin{array}{llllllllll}5 & 0.72 & 1.00 & 1.26 & 1.42 & 1.53 & 1.74 & 2.32 & 24.06\end{array}$

$\begin{array}{lllllllll}10 & 0.82 & 1.13 & 1.43 & 1.62 & 1.75 & 2.00 & 2.67 & 25.79\end{array}$

$\begin{array}{lllllllll}25 & 0.95 & 1.31 & 1.66 & 1.89 & 2.04 & 2.32 & 3.14 & 27.9^{(b)}\end{array}$

$\begin{array}{llllllllll}50 & 1.07 & 1.49 & 1.88 & 2.13 & 2.30 & 2.61 & 3.57 & 29.0\end{array}$ (b)

$\begin{array}{lllllllll}10 \mathrm{C} & 1.19 & 1.64 & 2.08 & 2.36 & 2.55 & 2.90 & 4.00 & 30.24\end{array}$
(a) Abeele 1981.
(b) Interpolated values. 
period ( 2 to 100 years) are presented. Based on comparisons with the 74-year record of 24-h precipitation for Los Alamos, the estimates from the NOAA Atlas-2 are $20 \%$ higher than the observations.

\section{2 .3 Wind}

Annual wind roses for $\mathrm{OHL}$ and Area $G$ are presented in Figures 1.12 and 1.13. The distribution of wind direction at OHL reflects 1 ) the location of Los Alamos on the southern side of the midlatitude westerlies and 2) the northwest-southeast slope of the Jemez Mountains and Pajarito Plateau. Predominance of winds from northwest to southwest is produced by the westerlies, which are often as far south as New Mexico. The slope of the terrain produces a distinct daily pattern under weak atmospheric pressure gradients. At nights drainage winds (less than $2.5 \mathrm{~m} / \mathrm{sec}$ ) flow down from the Jemez Mountains out of the northwest to west northwest. During the day, light upslope winds come up the plateau out of the southeast to southsoutheast.

The winds at Area $G$ are more predominantly from the southwest to the south. This reflects the more eastern location on the Pajarito plateau of Area $G$. At Area $G$, the north-northeast to soutri-southwest slope of the Rio Grande River Valley is dominant. Although the diurnal cycle of eastsoutheast upslope, west-northwest drainage flow is still present, similar to $\mathrm{OHL}$, a north-northeast to south-scuthwest diurnal flow along the axis of the Rio Grande is also present.

Wind patterns at other locations on the mesa tops across the Laboratory will resemble the OHL or Area $G$ data depending upon the proximity to one of these sites. The Pajarito Plat?au is crossed by a series of deep east-west oriented canyons cut by intermittent streams, and the wind patterns observed in these canyons is often uncoupled from the flow on the mesa tops. During the winter months, when the low sun angle reduces the number of daylight hours down in the canyons, down-canyon drainage flow can be observed throughout the entire day.

Return-period wind speeds, presented in Table 1-4, have been calculated for the Los Alamos National Laboratory (Coates 1984) on the basis of long-term wind records for Albuquerque, New Mexico. These wind speeds 

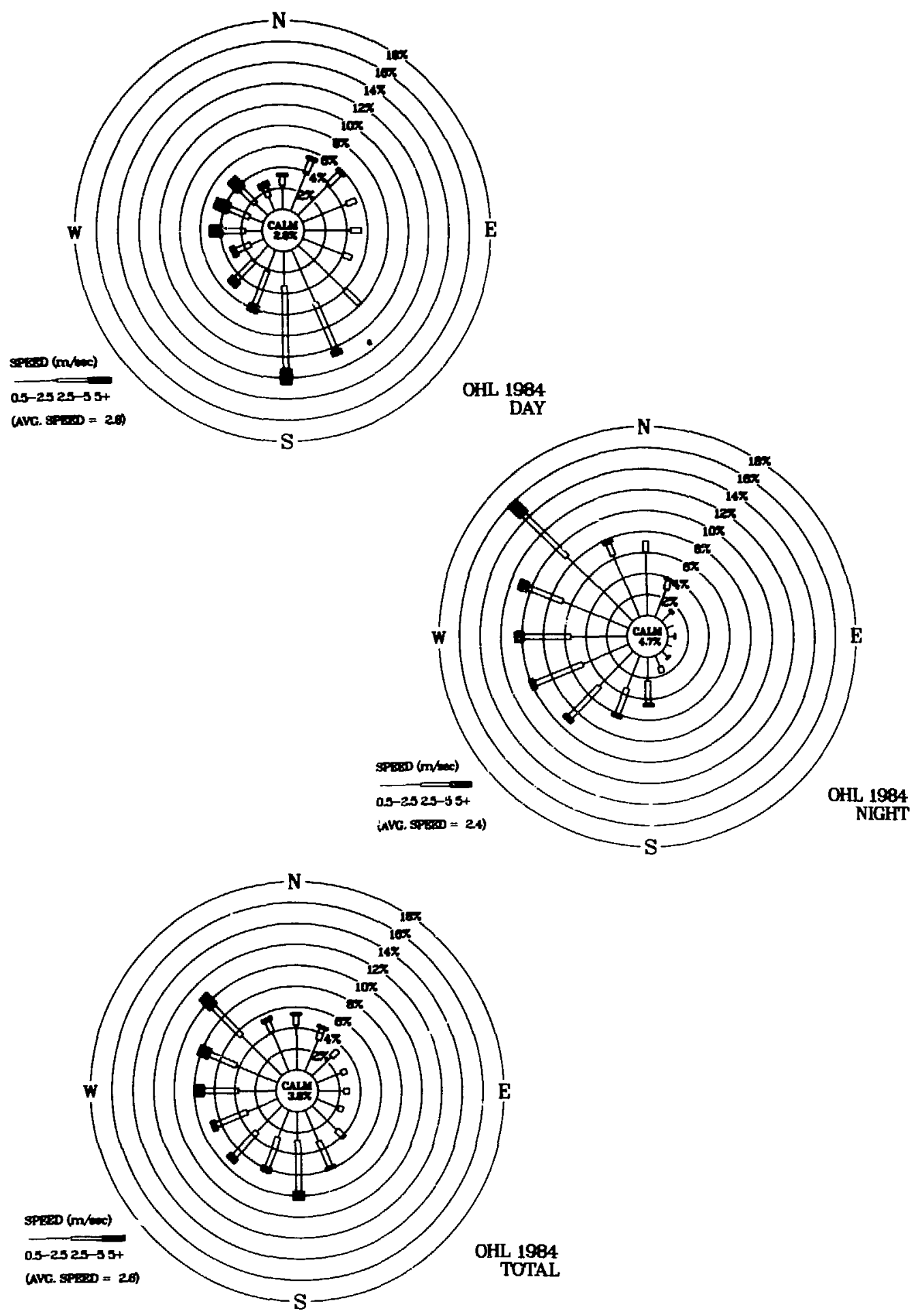

FIGURE 1.12. Annual Wind Roses for OHL. 


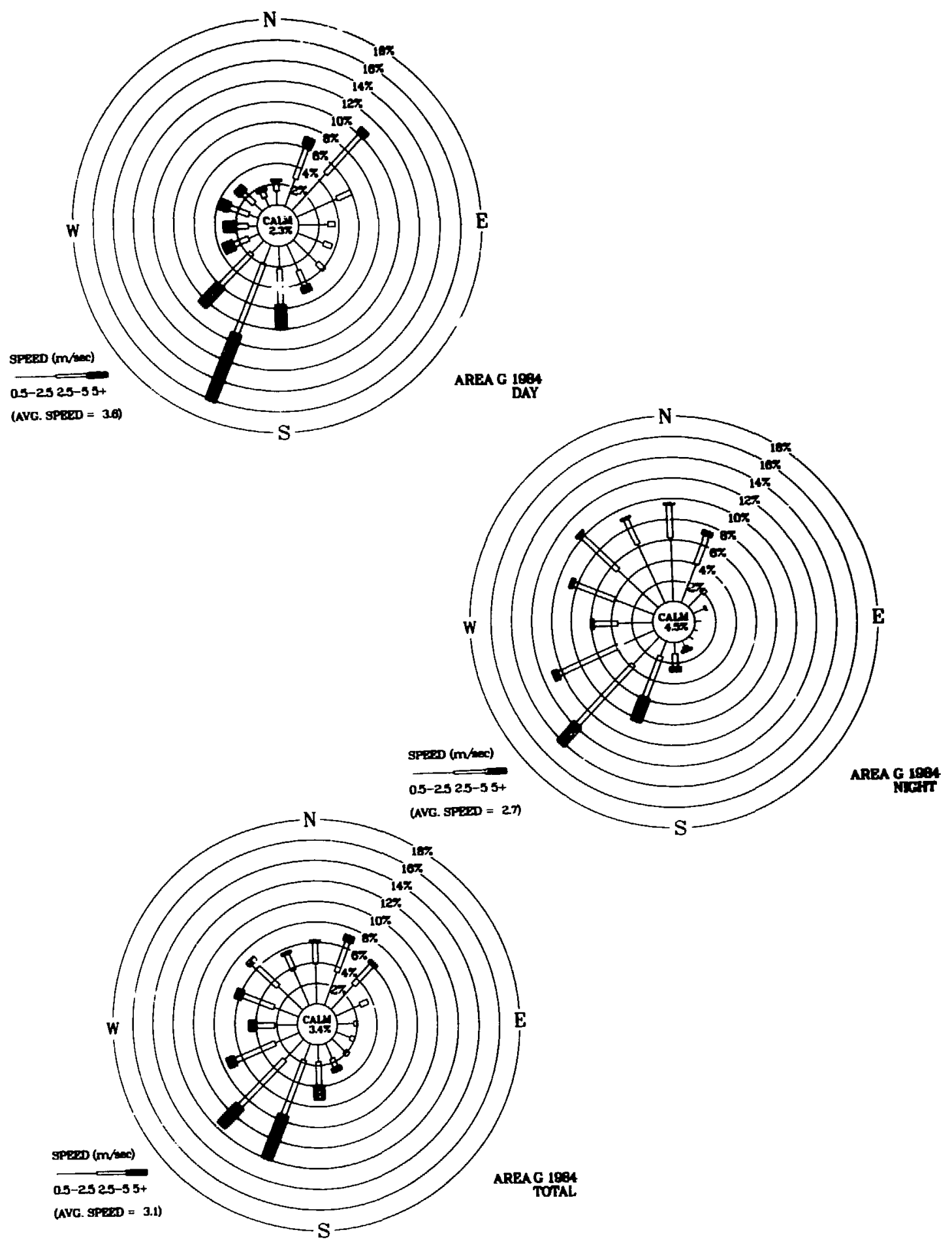

FIGURE 1.13. Annual Wind Roses for Area G. 
TABLE 1-4. Return-Period Wind Speeds for Los Aiamos

\begin{tabular}{|c|c|c|}
\hline \multirow{2}{*}{$\begin{array}{l}\text { Return Period } \\
\text { (years) } \\
\end{array}$} & \multicolumn{2}{|c|}{ Wind Speed } \\
\hline & $\mathrm{m} / \mathrm{s}$ & $\mathrm{mph}$ \\
\hline 102 & 35.8 & 80 \\
\hline $10^{3}$ & 41.6 & 93 \\
\hline $10^{4}$ & 47.4 & 106 \\
\hline 105 & 55.0 & 123 \\
\hline 106 & 59.5 & 133 \\
\hline
\end{tabular}

represent straight winds; straight winds dominate the expected wind speeds for return periods of one to one million years.

\subsubsection{Air Pollution}

Air quality in Los Alamos County is very good. No major point sources of primary air pollutants (sulfur dioxide, carbon monoxide, ozone, lead, and nitrous oxides) are in the county. The largest sources of air pollutants are automobile traffic and windblown dust.

Airborne particulate concentrations are measured in Los Alamos and White Rock. The annual secondary National Ambient Air Quality Standard (NAAQS), $60 \mu \mathrm{g} / \mathrm{m}^{3}$, is not exceeded. However, on several windy days each year, the $24-\mathrm{h}$ secondary NAAQS, $150 \mu \mathrm{g} / \mathrm{m}^{3}$, is exceeded.

\subsection{SUPPORTING DATA}

\subsubsection{Meteorological Monitoring}

A National Weather Service cooperative observation station has been located in Los Alamos since 1911. Daily maximum and minimum temperatures and 24-h precipitation totals are available from 1911 to the present.

Wind data have been recorded on strip charts at various Laboratory locations since the 1940s. During the 1970s microprocessors were designed to record wind and other meteorological data on digital data tapes. These data are then stored in files at the Los Alamos Central Computing Facility. 
These most recently collected data and the cooperative observation data form the meteorological data base for Los Alamos.

A summary of the Laboratory meteorological tower network is presented in Table 1-5. Data measured at each tower are averaged or summed over 15-minute periods and recorded on digital tape at the tower and can be transmitted over a telephone line to a microcomputer at $\mathrm{OHL}, \mathrm{TA}-59$. Digital data collection at the OHL tower began in 1979; data from the other currently operating towers are available for 1 to 5 years.

Secondary meteorological monitoring stations, recording precipitation. are located at TA-21, White Rock, and the White Rock-Y. Daily maximum and minimum temperatures are also recorded at the White Rock station. These data are all recorded on strip charts.

The meteorological monitoring network was established to support dose calculations for unplanned and routine atmospheric releases and to support weather forecasting services. Humidity and precipitation data are also collected to support hydrological studies of liquid effluent and surface contamination transport. The meteorological tower at Area G, TA-54, was installed specifically to support environmental studies of the waste disposal area.

\subsubsection{Atmospheric Dispersion Modeling}

Atmospheric dispersion modeling is performed at Los Alamos to assess the impacts of rottine atmospheric emissions and unplanned atmospheric releases. These releases are primarily stack releases; however, there are also ground-level explosive releases from the Laboratory dynamic testing program.

Gaussian dispersion modeling equations are used with on-site meteorological measurements to calculate concentrations. Atmospheric dispersion coefficients, $\sigma_{y}$ and $\sigma_{z}$, are calculated from the measured standard deviation of the horizontal and vertical wind directions. Plume or puff rise is calculated using the equations presented by Briggs (1975); explosive cloud $r i s e$ is calculated based on the amount of explosives involved (Church 1969). Radioactive decay is taken into account for those radionuclides with short half-lives. 
TABLE 1-5. Los Alamos Meteorological Tower Network

\begin{tabular}{|c|c|c|c|}
\hline $\begin{array}{c}\text { Tower } \\
\text { Location }(a) \\
\end{array}$ & $\begin{array}{l}\text { Height } \\
(\mathrm{m}) \\
\end{array}$ & Parameters Measured & $\begin{array}{c}\text { Remote } \\
\text { Interrogation } \\
\text { Capability } \\
\end{array}$ \\
\hline OHL, TA-59 & 22 & $\begin{array}{l}\text { Wind, temperature, } \\
\text { humidity, pressure, } \\
\text { dew point, solar radia- } \\
\text { tion, precipitation }\end{array}$ & Yes \\
\hline Area $G, T A-54$ & 10.5 & $\begin{array}{l}\text { Wind, temperature, } \\
\text { humidity, solar radia- } \\
\text { tion, precipitation }\end{array}$ & $\begin{array}{l}\text { Yes } \\
\text { (Not installedi }\end{array}$ \\
\hline East Gate, "A" & 12 & $\begin{array}{l}\text { Wind, temperature, } \\
\text { relative humidity, } \\
\text { solar radiation, } \\
\text { precipitation }\end{array}$ & $\begin{array}{l}\text { Yes } \\
\text { (Not installed) }\end{array}$ \\
\hline$T A-50$ & 91.5 & Wind, temperature & $\begin{array}{l}\text { Yes } \\
\text { (Not installed) }\end{array}$ \\
\hline LAMPF, TA -54 & 12 & Wind & No \\
\hline $\begin{array}{l}\text { Transportable } \\
\text { (not instrumented) }\end{array}$ & 30.5 & Wind & No \\
\hline $\begin{array}{l}\text { TA-16 } \\
\text { (Not installed) }\end{array}$ & 21 & $\begin{array}{l}\text { Wind, temperature, } \\
\text { solar radiation, } \\
\text { precipitation }\end{array}$ & Yes \\
\hline $\begin{array}{l}\text { Bandelier, "D" } \\
\text { (Not installed) }\end{array}$ & 51 & $\begin{array}{l}\text { Wind, temperature, } \\
\text { solar radiation, } \\
\text { precipitation }\end{array}$ & Yes \\
\hline
\end{tabular}

(a) See Figure 1-10 for tower locations. 
A special field study is being conducted to measure and model atmospheric gamma radiation levels due to the routine release of air activation products from the Los Alamos Meson Physics Facility (LAMPF). High-pressure ion chambers (HPICs) are used to measure short-term dosage rates (hourly and daily) on the site boundary north of LAMPF. Concurrent meteorological data, measured at LANiPF (TA-53) and at the East Gate, combined with source-term measurements, are used to predict short-term doses. These predictions are then compared with the HFIC data to assess the dispersion model performance.

\subsubsection{Environmental Surveillance Program}

Routine monitoring for radiation, radioactive materials, and chemical substances on th: Laboratory site and in the surrounding region documents compliance with appropriate standards, identifies undesirable trends, provides information for the public, and contributes to general environmental knowledge (Environmental Survelllance Group 1985).

Regional monitoring stations are located within the five counties surrounding Los Alamos County (Figure 1.1) at distances up to $80 \mathrm{~km}$ (50 mi) from the Laboratory. They provide a basis for determining natural conditions beyond the range for potential influence of Laboratory operations. Perimeter stations are located primarily within about $4 \mathrm{~km}$ (2.5 $\mathrm{mi})$ of the Laboratory boundary and selected to correlate with locations in adjacent residential and community areas. They document conditions in areas regularly occupied by the general public and likely to be influenced by Laboratory operations. Onsite stations are within the Laboratory boundary and most are in areas accessible onty to employees during normal working hours. The number of stations in each group is shown in Table 1-6.

The types of routine monitoring conducted at these stations include measurements of radiation and collection of samples of air particulates, waters, soils, sediments, and foodstuffs for subsequent analysis.

Additional samples are collected at various times and locations to gain information about particular events, such as major runoff events in intermittent streams, nonroutine releases, or special studies. Each year, more than 18,000 analyses for chemical and radiochemical constituents are 
TABLE 1-6. Number of Sampling Locations

\begin{tabular}{|c|c|c|c|}
\hline Type of Monitoring & Regional & Perimeter & Onsite \\
\hline E.ternal radiation & 4 & 12 & 139 \\
\hline Air & 3 & 11 & 2 \\
\hline Surface and ground water & 6 & 33 & 27 \\
\hline Soils and sediments & 16 & 16 & 32 \\
\hline Foodstuffs & 8 & 5 & 9 \\
\hline
\end{tabular}

performed on these environmental samples. Resulting data are used for comparison with standards and background levels of radiation, dose calculations, and other interpretations.

Calculated maximum boundary doses and maximum individual doses for the past 6 years are shown in Figure 1.14. These estimated doses historically have been less than $4 \%$ of the 500-mrem/year standard. In 1984 the estimated maximum individual ciose was $6.2 \%$ of the Radiation Protection Standard. This dose resulted mostly from airborne emissions from the Los Alamos Meson Physics Facility (a linear particle accelerator).

$\therefore$ External Penetrating Radiation. Levels of external penetrating radiation (including $x$ and gamma rays and charged-particle contributions from cosmic, terrestrial, and manmade sources) in the Los Alamos area are monitored with thermoluminescent dosimeters (TLDS) at 155 locations divided into three networks.

Radiation levels (including natural background radiation from cosmic and terrestrial sources) are measured at regional, perimeter, and onsice locations (Figure 1.15) in the environmental network. No measurements at the regional or perimeter locations showed any statistically distinguishable increase in radiation that could be attributed to Laboratory operations. Some measurements at onsite stations were above background levels, as expected, reflricing ongoing research activities at the Laboratory.

Radiation levels were also measured by a TLD network covering one active and eight inactive low-level radioactive solid waste management areas (Section 1.3 .3 ). 


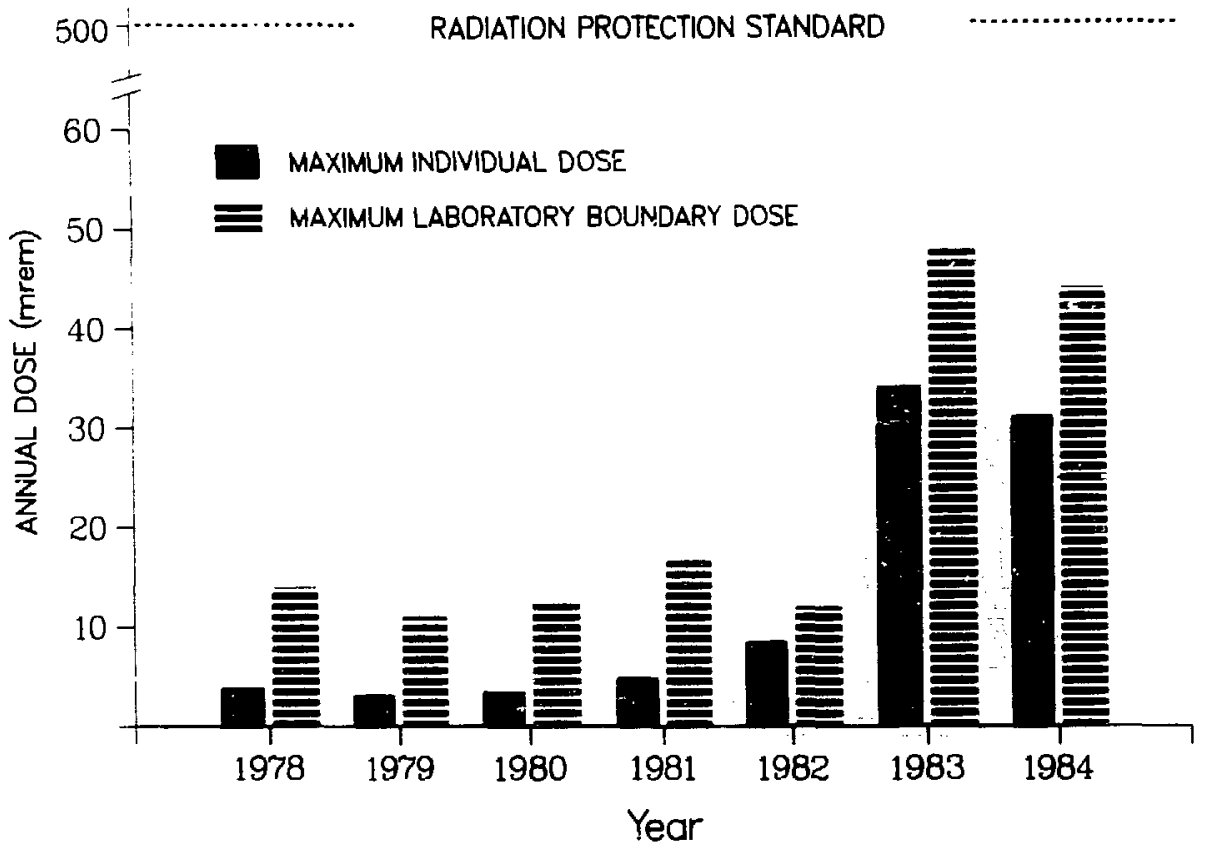

FIGURE 1.14. Summary of Estimated Maximum Individual and Maximum Laboratory Boundary Doses from Laboratory Operations (excluding contributions from cosmic, terrestrial, and medical diagnostic sources).

- Radioactivity in Air and Water. Measurements of radioactivity in air and water are compared with DOE Concentration Guides. For 1984 the annual averages (including amounts from cosmic, terrestrial, and global fallout sources) of the principal radionuclides in air and water potentially influenced by Laboratory operations were all less than $1 \%$ of the Concentration Guides.

During 1984, atmospheric concentrations of tritium, gross beta, americium, pilutonium, and uranium were measured at regional, perimeter, and onsite sampling locations. The annual averages for all 


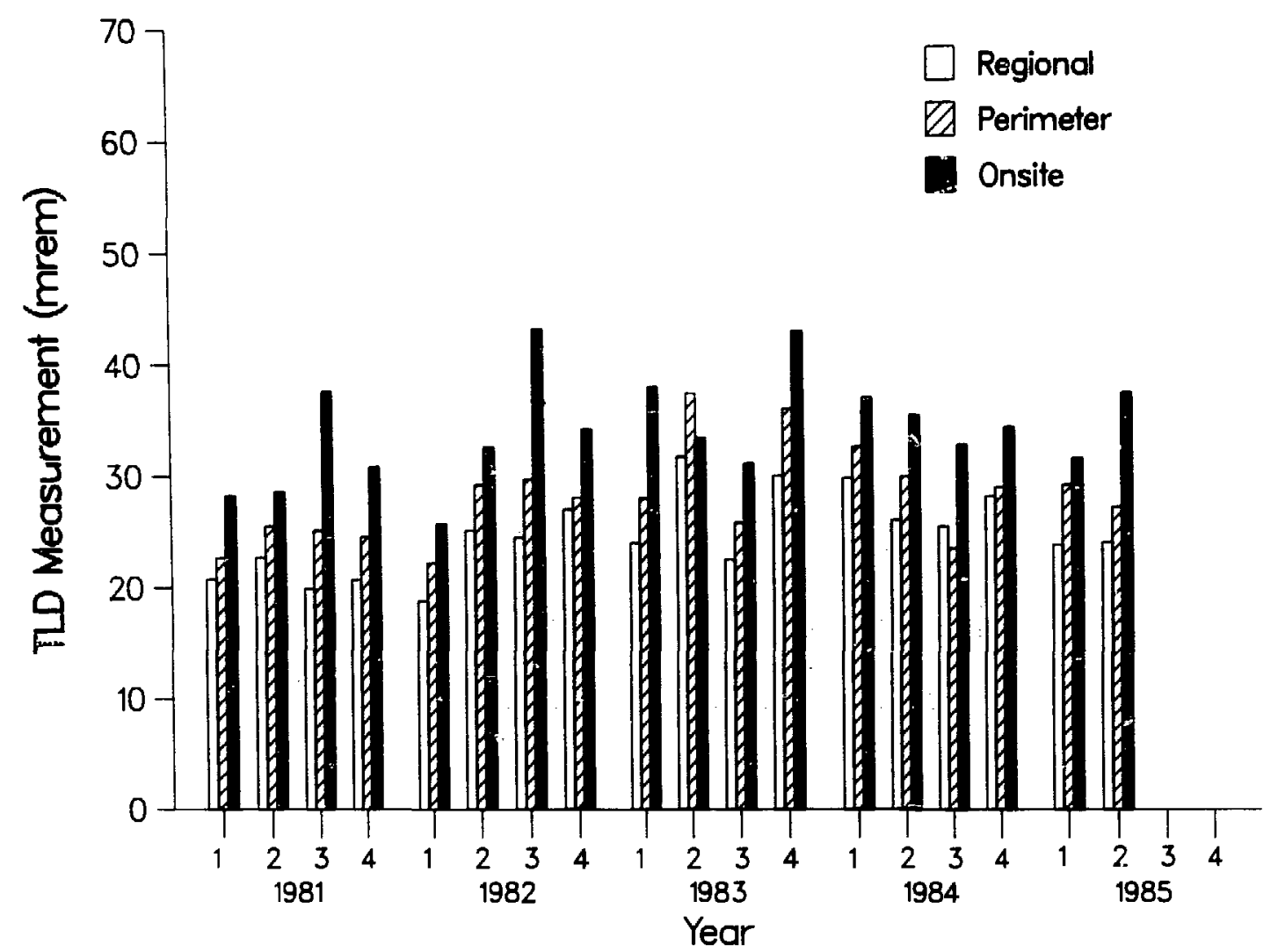

FIGURE 1.15. Quarterly Radiation TLD Measurements (which include contributions from cosmic, terrestrial, and Laboratory radiation sources, for regional, perimeter, and onsite locations for the past 5 years.

these radioactive constituents were much less than $1 \%$ of the Department of Energy's Concentration Guides. Oniy the atmospheric tritium concentrations showed any measurable impact from Laboratory operations. The impact was insignificant and toes not pose an environmental or health problem.

Surface and ground waters are monitored to provide routine surveillance of potential dispersion of radionuclides from Laboratory operations. Only the waters in onsite liquid-effluent release areas 
contain radioactivity in concentrations that are above natural terrestrial and worldwide fallout levels. However, these concentrations are still small fractions of the Concentration Guides. These onsite waters are not a source of industrial, agricultural, or municipal water supplies. Results of the 1984 radiochemical quality analyses of water from regional, perimeter, water supply, and onsite areas (where no effluents are released) indicate no significant effect from effluent releases from the Laboratory.

The water supply met all applicable US Environmental Protection Agency chemical quality and radioactivity standards. The integrity of geological formations protecting the deep ground-water aquifer was confirmed by lack of any measurements indicative of nonnatural radioactivity in municipal water supply sources.

- Radioactivity in 0ther Media. Measurements of radioactivity in samples of soils, sediments, and foodstuffs are made to provide information on less direct natural mechanisms that could result in exposures to people.

Measurements of radioactivity in soils and sediments are also useful for monitoring and understanding hydrologic transport of some radioactivity that occurs in intermittent stream channels in and adjacent to low-level radioactive waste management areas. Pueblo, Los Alamos, and Mortandad Canyons all have concentrations of radioactivity on sediments at levels higher than those attributable to natural terrestrial or worldwide fallout concentrations. Some radioactivity on sediments in Pueblo Canyon (from pre-1964 effluent disposal) and upper Los Alamos Canyon (from 1952 to current treated-effluent disposal) has been transported during runoff events to the Rio Grande. Theoretical estimates, confirmed by measurements, show the incrementai effect on Rio Grande sediments is small in comparison with levels of activity on soils and sediments attributable to worldwide fallout and to variability in such measurements. The low levelis of radioactivity in Mortandad Canyon are from treated liquid effluents from the treatment plant. Mo radioactivity on sediments or in water has been transported past 
the Laboratory boundary in Mortandad Canyon. Radionuclide concentrations in onsite soil samples were at or below natural terrestrial and global fallout background levels.

Most fruit, vegetable, fish, and honey samples from offsite locations showed no increments of radioactivity distinguishable from that attributable to natural sources or worldwide fallout. Fruit from onsite trees had slightly elevated tritium concentrations. A person eating all the fruit from the trees with the maximum tritium concentration would receive a dose less than $1 \%$ of the Department of Energy's Radiation Protection Standard. Game fish samples from Cochiti Reservoir, when compared with samples from the background stations, had slightly higher uranium concentrations. These levels are believed to be caused by natural phenomena. Eating a year's supply of fish with these levels would give a 50-year dose commitment less than $1 \%$ of the Radiation Protection Standard. Doses from eating honey from hives located on Laboratory land would be less than $1 \%$ of the Radiation Protection Standard.

\subsubsection{Solid Waste Site Surveillance Program}

Radioactivity concentrations in air (particulates and moisture), water, soil, and sediment are measured along with the levels of penetrating radiation (Environmental Surveillance Group 1984 and 1985). Nine radioactive solid waste management sites are monitored; one is currently active (Area $G$ ) and the remainder are inactive (Areas $A, B, C, E, F, T, U$, and $V$ ) (Figure 1.16). The general public is excluded from these waste management sites because they are controlled-access areas.

- External Penetrating Radiation Measurements. Levels of external penetrating radiation (including $x$ and gamma rays and charged-particle contributions from cosmic, terrestrial, and manmade sources) are measured at the nine waste management sites. TIDs attached to the site perimeter fences measure radiation from both natural background and manmade sources.

During 1984 levels of external penetrating radiation were measured using TLDs at 9 of the 11 waste management areas. Areas $W$ and $X$ 


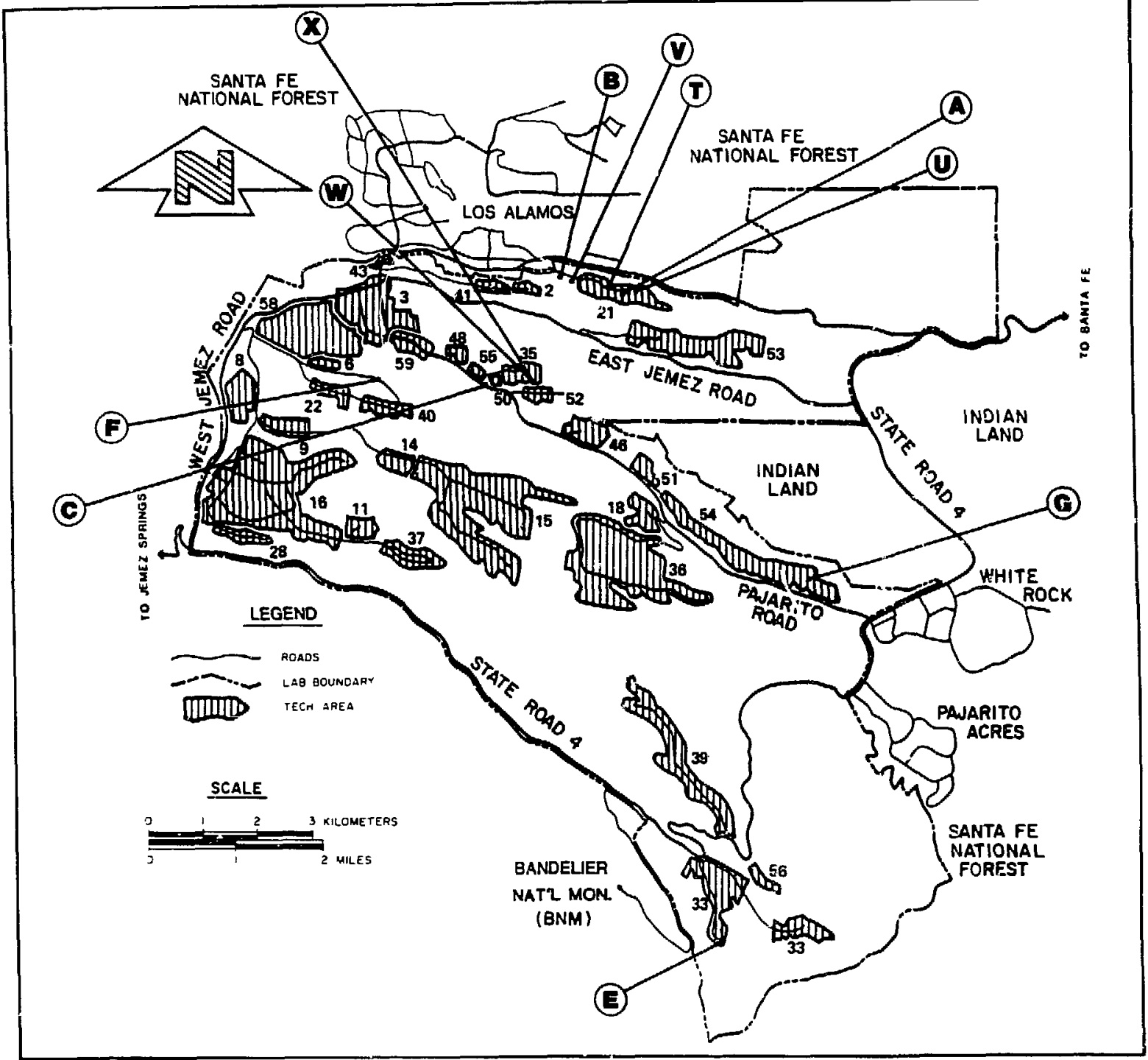

FIGURE 1.16. Locations of Active (Area G) and Inactive Radioactive Waste Disposal Areas.

were not monitored with TLDs because they consist oniy of buried vessels that offer little opportunity for radiation exposure at the ground surface.

The 1984 annual TLD measurements for the waste management areas are in Table 1-7. For comparison, natural background radiation varied from 80 to $151 \mathrm{mrem} /$ year during 1984 in the Los Alamos region. A 
TABLE 1-7. External Penetrating Radiation Measurements at Waste Management Areas During 1984

\begin{tabular}{|c|c|c|c|c|c|}
\hline \multirow[b]{2}{*}{ Area } & \multirow{2}{*}{$\begin{array}{l}\text { No. of } \\
\text { Sampling } \\
\text { Locations }\end{array}$} & \multirow{2}{*}{$\begin{array}{c}\text { No. of } \\
\text { Quarterly } \\
\text { Measure- } \\
\text { ments } \\
\end{array}$} & \multicolumn{3}{|c|}{ Annual Measurement (mrem) } \\
\hline & & & Maximum & Minimum & Mean \\
\hline \multicolumn{6}{|c|}{ Inactive } \\
\hline A & 5 & 20 & $133.1 \pm 9.3$ & $127.1 \pm 9.3$ & $130.6 \pm 4.7$ \\
\hline B & 23 & 88 & $138.4 \pm 9.3$ & $117.5 \pm 9.3$ & $127.6 \pm 12.5$ \\
\hline c & 18 & 64 & $145.9 \pm 9.4$ & $116.1 \pm 9.4$ & $131.1 \pm 19 . v$ \\
\hline E & 4 & 0 & -- & --- & $-\infty$ \\
\hline $\mathrm{F}$ & 2 & 4 & $114.1 \pm 9.3$ & $114.1 \pm 9.3$ & $114.1 \pm 9.3$ \\
\hline $\mathrm{T}$ & 7 & 20 & $280.9 \pm 10.1$ & $135.8 \pm 9.3$ & $167.9 \pm 126.6$ \\
\hline$u$ & 2 & 8 & $151.8 \pm 9.3$ & $148.5 \pm 9.3$ & $150.0 \pm 4.2$ \\
\hline$v$ & 4 & 0 & -- & --- & --- \\
\hline \multicolumn{6}{|l|}{ Active } \\
\hline G & 27 & 92 & $246.8 \pm 8.8$ & $130.7 \pm 8.4$ & $158.0 \pm 49.1$ \\
\hline
\end{tabular}

holding tank for radioactive liquid wastes from current operations and buried wastes from past operations at Area $T$ caused this area's relatively higher measurement. Several transient elevated TLD measurements at Area $G$ were due to handling and storing of the wastes before their burial.

- Radionuclide Concentrations in Soils and Bedrock. During 1983, surface and subsurface soil samples (Table 1.8) were taken at eight inactive low-level radioactive waste management areas. These samples were analyzed for $3 \mathrm{H}, 137 \mathrm{Cs}, 239^{-} 240 \mathrm{Pu}$, and total U. Gamma spectra analyses were also done on the samples.

The subsurface $3 \mathrm{H}$ and uranium data show some migration from buried wastes. Howaver, better packaging procedures have greatly improved containment (Wheeler and Warren 1975). The subsurface $137 \mathrm{Cs}$ data are marginaliy above detectable concentrations from a few sites. 
TABLE 1-8. Radionuclide Concentrations in Solls and Bedrock at the Low-Level Radioactive Waste Management Areas During 1983

Surface Soils

\begin{tabular}{|c|c|c|c|}
\hline & $\begin{array}{c}{ }^{3 H} \\
\left(10^{-6} \mu \mathrm{Ci} / \mathrm{m} \ell\right) \\
\end{array}$ & $\begin{array}{l}\text { Total U } \\
\underline{(\mu g / g)}\end{array}$ & $\begin{array}{r}239-240 \mathrm{Pu} \\
(\mathrm{pCi} / \mathrm{g}) \\
\end{array}$ \\
\hline \multicolumn{4}{|l|}{ Depth $0-1 \mathrm{~cm}$} \\
\hline Range & $5.1-81$ & $3.0-4.1$ & $0.02-0.07$ \\
\hline $\bar{x} \pm 2 s$ & $24 \pm 30$ & $3.6 \pm 0.7$ & $0.04 \pm 0.04$ \\
\hline No. of Samples & 86 & 6 & 5 \\
\hline \multicolumn{4}{|l|}{ Depth $1-10 \mathrm{~cm}$} \\
\hline Range & $6.2-115$ & $3.3-3.7$ & $0.002-0.04$ \\
\hline $\bar{x} \pm 2 s$ & $22 \pm 37$ & $3.6 \pm 0.4$ & $0.02 \pm 0.03$ \\
\hline No. of Samples & 83 & 6 & 6 \\
\hline \multicolumn{4}{|l|}{ Depth $10-30 \mathrm{~cm}$} \\
\hline Range & $3.1-66$ & $2.9-3.3$ & $0.001-0.02$ \\
\hline $\bar{x} \pm 2 s$ & $12 \pm 20$ & $3.2 \pm 0.4$ & $0.007 \pm 0.02$ \\
\hline No. of Samples & 38 & 4 & 4 \\
\hline
\end{tabular}

Subsurface Soils and Bedrock

\begin{tabular}{|c|c|c|c|c|}
\hline & $\begin{array}{c}{ }^{3} \mathrm{H} \\
\left(10^{-6}{ }_{\mu} \mathrm{Ci} / \mathrm{ml}\right) \\
\end{array}$ & $\begin{array}{c}137 \mathrm{Cs} \\
(\mathrm{pCi} / \mathrm{g}) \\
\end{array}$ & $\begin{array}{l}\text { Total U } \\
(\mu g / g)\end{array}$ & $\begin{array}{c}239-240 \mathrm{pu} \\
(\mathrm{pCr} / \mathrm{g})\end{array}$ \\
\hline \multicolumn{5}{|l|}{ Depth $0.0-0.9 \mathrm{~m}$} \\
\hline Range & $4.5-29$ & $0.01-0.46$ & $3.0-4.8$ & -- \\
\hline $\bar{x} \pm 2 s$ & $12 \pm 13$ & $0.19 \pm 0.30$ & $3.8 \pm 1.1$ & -- \\
\hline No. of Samples & 12 & 11 & 11 & -- \\
\hline \multicolumn{5}{|l|}{ Depth $>0.9 \mathrm{~m}$} \\
\hline Range & $7.1-90$ & $0.00-0.72$ & $2.7-62$ & $0.000-2.2$ \\
\hline $\bar{x} \pm 2 s$ & $30 \pm 44$ & $0.08 \pm 0.23$ & $4.3-11$ & $0.06 \pm 0.51$ \\
\hline No. of Samples & 88 & 121 & 122 & 118 \\
\hline
\end{tabular}


The subsurface $239^{-240 P u}$ data at Area $T$ show some contamination transport from liquid waste storage and disposal uperations that were begun in the 1940s and 1950s. Downward migration of plutonium occurs below Area $T$, but there is little lateral movement (Nyhan et a 1. 1983a). This subsurface contamination transport was caused by intentional experimental flooding (the flooding was many times that which could be expected from precipitation) of plutonium absorption beds in 1961. Presently no water, i.e., liquids, is disposed of into the beds, and any further plutonium movement is not likely without significant intentional water additions.

Low levels of subsurface plutonium contamination are at Area $A$ (possibly from leaks in liquid waste storage tanks that have been emptied) and at Area $V$ (from migration of plutonium in laundry waste water that was discharged into a former lagoon system). These plutonium concentrations are several orders of magnitude below published guidance for remedial action (US DOE 1983 and Gilbert et al. 1983).

- Air Sampling Results. At the end of 1983, four new air sampling stations were placed around the perimeter of TA-54 (Area G) to supplement the existing air sampler at the site (Figure 1.17). Area $G$ is the only active radioactive solid waste management site at the Laboratory. Air particulate and moisture samples from these stations are analyzed for $3 \mathrm{H}, 238 \mathrm{Pu}, 239-240 \mathrm{Pu}, 24 \mathrm{Am}$, and total $\mathrm{U}$. The air sampling data for the existing air sampler (Station 22) showed no unusual data during 1983. All airborne radionuclide concentrations were less than 1\% of the Department of Energy's Concentration Guides.

Air sampling data for the last quarter of 1984 are in Table 1-9. The highest mean tritium concentration of $1290 \times 10^{-12} \mu \mathrm{Ci} / \mathrm{me}(0.03 \%$ of Department of Energy's Concentration Guide for Controlled Areas) occurred at Station G-2. This station is near burial shafts that are used for disposal of liquid scintillation vials, which contain smali amounts of tritium. The uranium concentrations were at background leve1s. Only one $239-240 \mathrm{Pu}$ concentration was above the minimum detectable limit of $3 \times 10^{-18} \mu \mathrm{Ci} / \mathrm{ml}$. A concentraticn of $7.7 \times 10^{-18}$ ${ }_{\mu} \mathrm{Ci} / \mathrm{m} \ell \quad 10.0004 \%$ of the Department of Energy's Concentration Guide for 
TABLE 1-9. 1984 Air Sampling Results for Fourth Quarter at Area G (TA-54)

$\mathrm{pC} 1 / \mathrm{m}^{3}\left(10^{-12}{ }_{1} \mathrm{Cl} / \mathrm{m} \ell\right)$

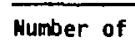

G-2

G-3

$G-4$

\section{Samples}

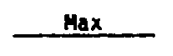

\begin{tabular}{|c|c|}
\hline $80 \pm 20$ & $25 \pm 5$ \\
\hline $80 \pm 10$ & $17 \pm 3$ \\
\hline $100 \pm 400$ & $280 \pm 50$ \\
\hline
\end{tabular}

$2100+400 \quad 280 \pm 50$

$21 \pm 4$

$6 \pm 1$

$34 \pm 7$

\section{Mean as}

Mean

$62 \pm 64$

$45 \pm 64$

$1290 \pm 1850$

$13 \pm 15$

$24 \pm 19$

Total $U$

$\left(\mathrm{pg} / \mathrm{m}^{3}\right)$

ICG (b) Samples

Mean

Mean as

239-240 Pu

$\frac{\mathrm{aC} 1 / \mathrm{m}^{3}\left(10^{-18}{ }_{\mathrm{u}} \mathrm{C} 1 / \mathrm{m} 1\right)}{\text { Mumber of }}$

$12 \pm 1.3 \quad 0.00001$

$24 \pm 2.7 \quad 0.00001$

$6.4 \pm 0.7 \quad 0.00000$

$12 \pm 1.2 \quad 0.00001$

$5.0 \pm 0.6 \quad 0.00000$

Mean ICG (b)

$0.5 \pm 0.3 \quad 0.00005$ $7.7 \pm 1.0 \quad 0.0004$

$0.2 \pm 0.2 \quad 0.00001$

$0.3 \pm 0.2 \quad 0.00002$

$0.1 \pm 0.2 \quad 0.00000$

(a) See Figure 1-17 for map of station locations.

(b) Controlled Area Concentration Guides: $3 \mathrm{H}=2 \times 10^{-6} \mu_{\mathrm{St}} / \mathrm{mg}$, Total $\mathrm{U}=1.8 \times 10^{\mathrm{B}} \mathrm{pg} / \mathrm{m}^{3}$, and $239-240 \mathrm{Pu}=2 \times 10^{-12}{ }_{\mu} \mathrm{Cl} / \mathrm{ml}$. 


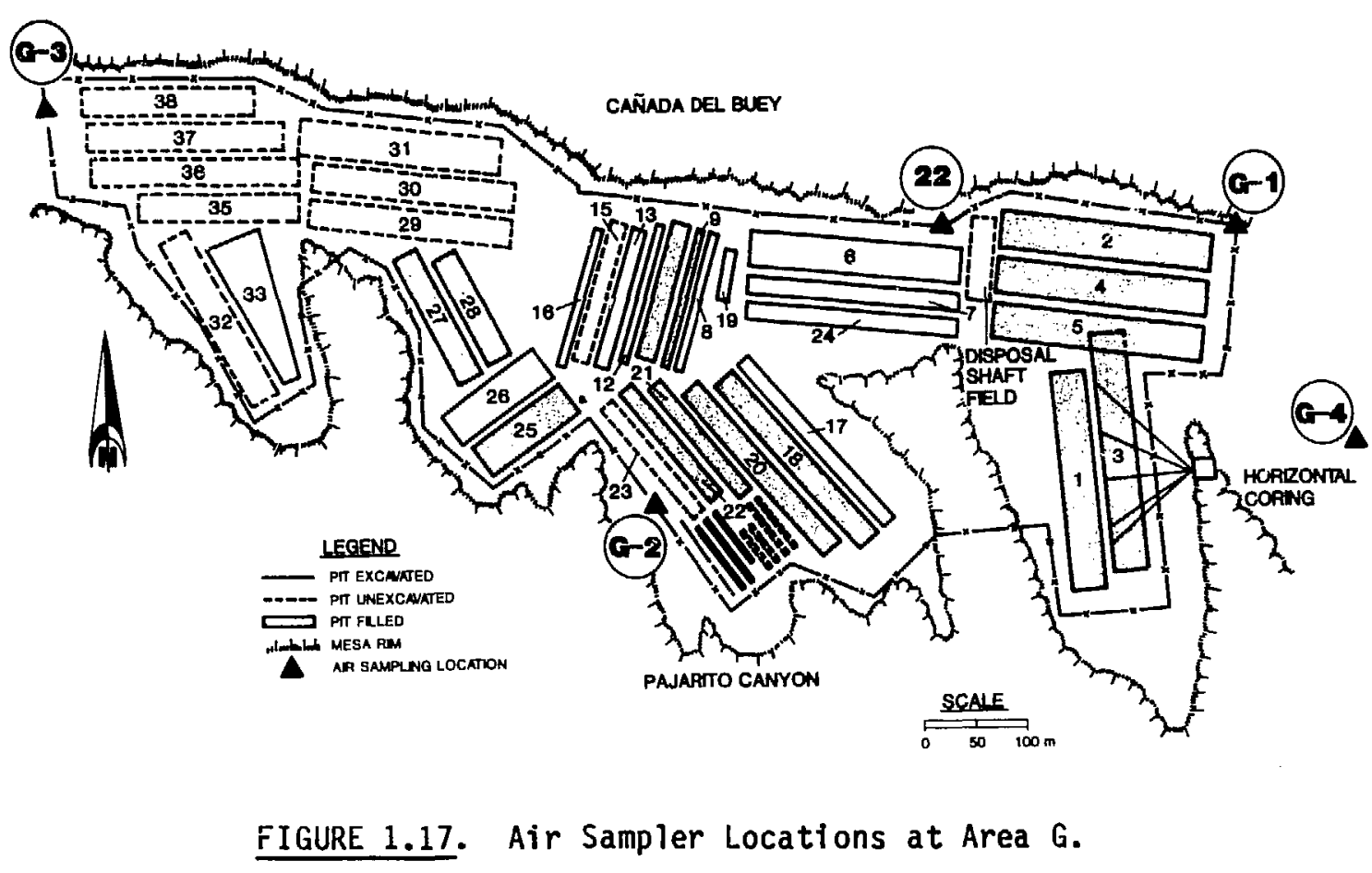

Controlled Areas) was measured at Station G-1. This station is downwind from handling and storing operations at the transuranic waste storage pads.

- Monitoring Results for Areas B and C. Environmental monitoring of Areas $B$ and $C$ was completed during 1984. Soil and vegetation samples were collected from three perimeter locations around Area $B$ and four perimeter locations around Area $C$. Samples were taken in surface runoff areas around the perimeters of the areas to monitor transport of radionuclides from the waste areas, should transport occur.

Results of the sampling are in Table 1-10. For comparison, concentrations in regional (background) soil samples range from about 1 to $4 \times 10^{-6}{ }_{\mu} \mathrm{Ci} / \mathrm{m} \ell$ for $3 \mathrm{H}$, about 2 to $3 \mu \mathrm{g} / \mathrm{g}$ for total $\mathrm{U}$, and about 0.000 to $0.015 \mathrm{pCi} / \mathrm{g}$ for $239-240 \mathrm{Pu}$. Although prior years' samples contained traces of $3 \mathrm{H}, 1984$ samples showed no evidence of $3 \mathrm{H}$ contamination at Area $B$ and little at Area $C$. Uranium concentrations in Areas $B$ and $C$ soil samples, althnugh slightly higher than regional 
TABLE 1-10. Radionuclide Concentrations in Perimeter Soll Samples from Waste Management Areas $B$ and $C$

\begin{tabular}{cll}
\multicolumn{3}{c}{ Area B } \\
\hline${ }^{3 H}$ & Total U & $239-240 \mathrm{Pu}$ \\
$\left(10^{-6} \mu \mathrm{Ci} / \mathrm{ml}\right)$ & $\underline{(\mu \mathrm{g} / \mathrm{g})}$ & $\underline{\mathrm{ipCi} / \mathrm{g})}$ \\
\hline
\end{tabular}

Depth: $0-1 \mathrm{~cm}$

$\begin{array}{lccc}\text { Range } & 2.4-4.8 & 4.9-5.7 & 0.5-3.1 \\ \bar{x} \pm 2 \mathrm{~s} & 3.2 \pm 2.7 & 5.3 \pm 0.7 & 1.7 \pm 2.6 \\ \text { No. of Samples } & 3 & 3 & 3\end{array}$

Depth: $1-10 \mathrm{~cm}$

$\begin{array}{lccc}\text { Range } & 1.8-2.7 & 5.2-6.0 & 0.6-7.4 \\ \bar{x} \pm 2 \mathrm{~s} & 2.3 \pm 0.9 & 5.5 \pm 0.9 & 3.0 \pm 7.6 \\ \text { No. of Samples } & 3 & 3 & 3\end{array}$

Depth: $10-30 \mathrm{~cm}$

$\begin{array}{lccc}\text { Range } & 1.8-2.4 & 4.0-4.8 & 0.39-1.2 \\ \bar{x} \pm 2 \mathrm{~s} & 2.2 \pm 0.7 & 4.5 \pm 0.8 & 0.65 \pm 0.91 \\ \text { No. of Samples } & 3 & 3 & 3\end{array}$

Depth $0-1 \mathrm{~cm}$

\begin{tabular}{cll}
\multicolumn{3}{c}{ Area C } \\
\hline${ }^{3 H}$ & Total U & $239^{-240 P u}$ \\
$\left(10^{-6}{ }_{\mu C i} / \mathrm{m} \ell\right)$ & $(\mu g / g)$ & $(\mathrm{pCT} / \mathrm{g})$ \\
\hline
\end{tabular}

$\begin{array}{lccc}\text { Range } & 9.9-20 & 3.7-5.6 & 0.05-5.9 \\ \bar{x} \pm 2 \mathrm{~s} & 15 \pm 8.3 & 4.4 \pm 1.9 & 1.8 \pm 5.6 \\ \text { No. of Samples } & 4 & 4 & 4\end{array}$

Depth $1-10 \mathrm{~cm}$

$\begin{array}{lccc}\text { Range } & 6.6-11 & 3.6-6.1 & 0.09-2.6 \\ \bar{x} \pm 2 \mathrm{~s} & 9.2 \pm 3.9 & 4.7 \pm 2.4 & 0.99 \pm 2.2 \\ \text { No. of Samples } & 4 & 4 & 4\end{array}$

Depth $10-30 \mathrm{~cm}$

$\begin{array}{lccc}\text { Range } & 7.9-22 & 3.6-5.6 & 0.33-8.5 \\ \bar{x} \pm 2 \mathrm{~s} & 14 \pm 13 & 4.4 \pm 1.8 & 2.5 \pm 8.1 \\ \text { No. of Samples } & 4 & 4 & 4\end{array}$


values, were within the range of variability in the natural crustal abundance of uranium.

Plutonium concentrations in the perimeter soil samples from Areas $B$ and $C$ evidenced low-level contamination. This contamination is about 30 times below the Department of Energy's remedial action guidelines (DOE 1983). Surface runoff from Area B empties into Small Canyon, a tributary to Los Alamos Canyon. Soil and sediment samples from these two canyons do not show any evidence of plutonium contamination from Area $B$.

- Radionuclide Transport in Sediments and Runoff. Radionuclides transported by surface runoff have an affinity for attachment to sediment particles by ion exchange or adsorption. Thus, radionuclides in surface runoff tend to concentrate on sediments in the stream channels that drain Area G. Nine sampiing stations are located outside the perimeter fence at Area $G$ to collect sediments that are transported from Area $G$ by surface runoff (Figure 1.18).

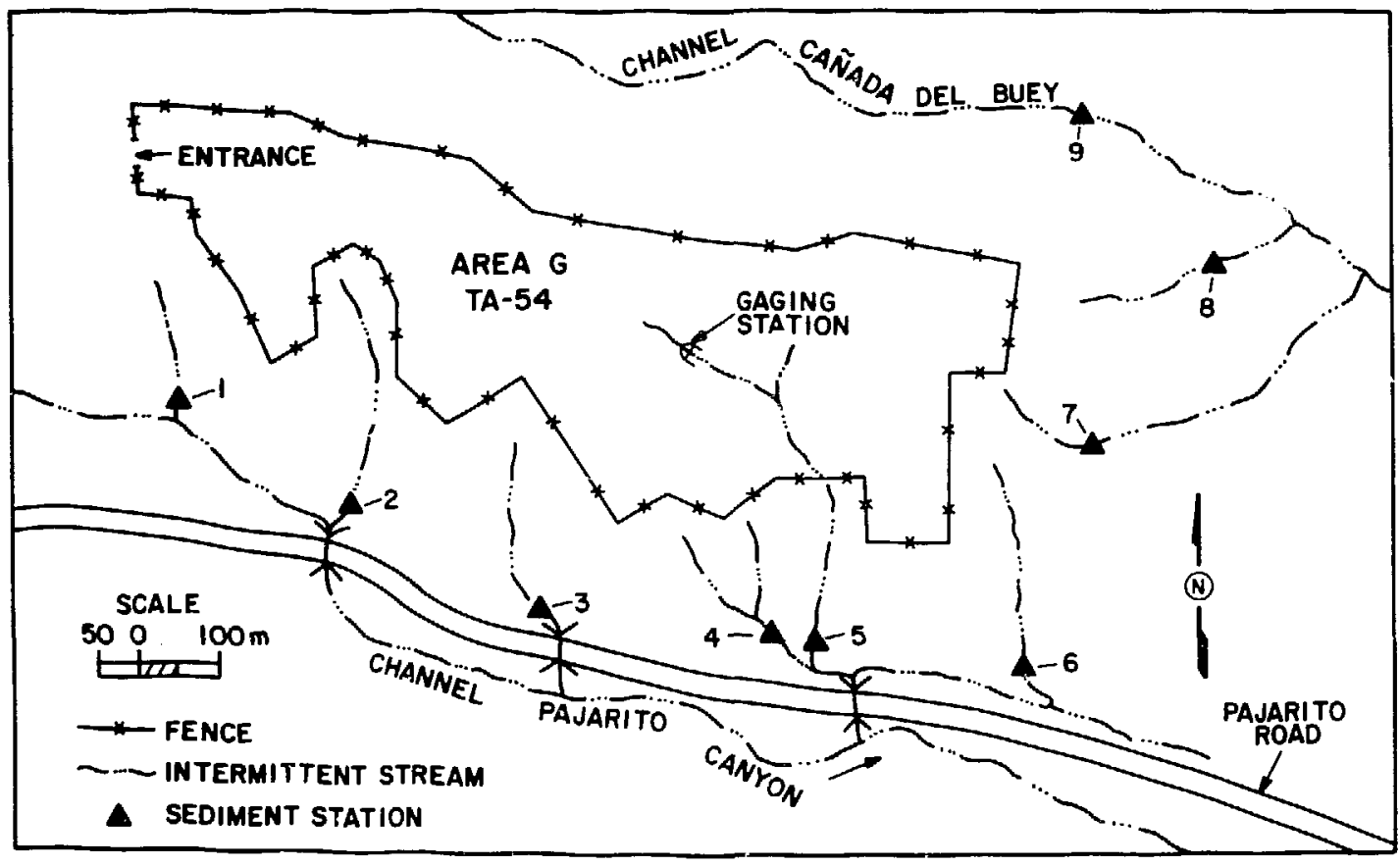

FIGURE 1.18. Surface Water Gaging Station in Area G (TA-54) and Sediment Sampling Stations Adjacent to Area G. 
The average concentrations of $137 \mathrm{Cs}(0.46 \mathrm{pCi} / \mathrm{g})$ and total uranium $(4.6 \mu \mathrm{g} / \mathrm{g})$ in sediments from the nine sediment stations were below regional background levels from 1978 through 1982 (Tables 1-11 and 1-12). Additional analyses (Table 1-11) of the sediments for $3 \mathrm{H}$ and gross gamma in 1984 indicated these concentrations were low when compared with the regional sediments in 1984 ( ${ }_{\mu} \mathrm{Ci} / \mathrm{l}$; gross gamma regional, 9.0 counts/min/g).

The 1984 average concentrations of $238 \mathrm{Pu}$ at Stations $3,4,5,7$, 8 , and 9 were above regional background concentrations. The average $238 \mathrm{Pu}$ and $239-240 \mathrm{Pu}$ concentrations at Stations 6,7 , and 8 also exceeded regional tackground concentrations (238Pu regional, 0.006 $\mathrm{pCi} / \mathrm{g} ; 239-240 \mathrm{Pu}$ regional, $0.042 \mathrm{pCi} / \mathrm{g}$ ). These above-background concentrati uns of $238 \mathrm{Pu}$ and $239-240 \mathrm{Pu}$ in the sediwents are similar to what was found in 1982 and 1983 and indicate some transport of surface contamination by runoff from Area G.

In 1984 the maximum concentration of $238 \mathrm{Pu}$ was $0.73 \mathrm{pCi} / \mathrm{g}$ or about 12 times greater than regional background concentrations or fallout levels. The $239-240 \mathrm{pu}$ maximum concentration was $0.44 \mathrm{pCi} / \mathrm{y}$ or about 10 times greater than regional background concentrations. Sampling in Canada del Buey at State Road 4 (SR-4) below Stations 7 , 8, and 9 and in Pajarito Canyon at SR-4 below Stations 1 through 6 (Area $G$ ) detected no concentrations above regional background levels. One runoff sample (Table 1-12) was coliected in the center of Area $G$ during 1984. The sample was analyzed for plutoritum in solution and in suspended sediments. The single runoff event contained no plutonium in solution or in suspended sediments when compared with sncwmelt run-off for 1083. During 1984 there was no snowmelt run-off at SR-4 in Pajarito Canyon.

\subsubsection{Preoperational Survey Baseline Program}

Preoperational environmental surveys are required by DOE Order 5484.1A for any new facility with a potential for adverse environmental impact. Survelllance data obtained from the preoperational surveys become part of the radioecological data base used to interpret the transport rates and food strain parameters used in the Los Alamos surveillance programs. 
TABLE 1-11. Radiochemical Analyses of Sediments and Kun-off at Area C (TA-54)

\section{Regiona 1}

1982

1983

1984

Stations

\begin{tabular}{|c|c|c|c|c|c|}
\hline Analyses & Units & $\begin{array}{c}1982 \\
(\bar{x} \pm 25)\end{array}$ & $\begin{array}{c}1983 \\
(\bar{x} \pm 2 s) \\
\end{array}$ & $\begin{array}{c}1984 \\
(\bar{x} \pm 2 s)\end{array}$ & $\begin{array}{c}1978-1982 \\
(\bar{x} \pm 25)\end{array}$ \\
\hline & \multicolumn{5}{|c|}{ Sediment Stations } \\
\hline $137 \mathrm{Cs}$ & $\mathrm{pCi} / \mathrm{g}$ & $0.30 \pm 0.4 i$ & $0.23 \pm 0.20$ & $0.2 \pm 21$ & 0.46 \\
\hline $238 \mathrm{Pu}$ & $\mathrm{pCi} / \mathrm{g}$ & $0.11 \pm 0.025$ & $0.033 \pm 0.107$ & $0.023 \pm 0.016$ & 0.006 \\
\hline $239-240 \mathrm{Pu}$ & $\mathrm{pCl} / \mathrm{g}$ & $0.032 \pm 0.104$ & $0.0340 \pm 1.60$ & $0.088 \pm 0.295$ & 0.042 \\
\hline $3 \mathrm{H}$ & $10^{-6} \mu \mathrm{Ci} / \mathrm{m} 2$ & $-\infty$ & - & $2.9 \pm 2.1$ & $3.9^{(a)}$ \\
\hline Total U & $\mu g / g$ & $3.2 \pm 1.9$ & $3.7 \pm 2.3$ & $3.3 \pm 1.7$ & 4.6 \\
\hline Gross gamma & counts/min/g & -- & $5.9 \pm 4.1$ & $6.8 \pm 3.9$ & $9.0^{(a)}$ \\
\hline
\end{tabular}

Run-off at Gaging Station

$\begin{gathered}\text { Pajarito } \\ \text { Canyon } \\ 1983 \\ (\bar{x} \pm 2 s)^{(b)} \\ 0.014 \\ -0.002\end{gathered}$

Solution

$\begin{array}{lllllr}238 \mathrm{Pu} & 10^{-9}{ }_{\mu \mathrm{Ci} / \mathrm{m} \ell} & 0.027 \pm 0.051 & 0.001 \pm 0.001 & -0.012 \pm 0.024 & 0.014 \\ 239^{-240 \mathrm{Pu}} & 10^{-9}{ }_{\mu \mathrm{Ci} / \mathrm{m} \ell} & 0.013 \pm 0.056 & 0.002 \pm 0.002 & 0.012 \pm 0.024 & -0.002\end{array}$

Suspended Sediments

$\begin{array}{llllll}238 \mathrm{Pu} & \mathrm{pCi} / \mathrm{g} & 1.1 \pm 0.28 & 3.2 \pm 0.32 & -0.008 \pm 0.010 & 0.79 \\ 239-24 \mathrm{DPu} & \mathrm{pCi} / \mathrm{g} & 1.3 \pm 0.24 & 5.0 \pm 0.12 & -0.003 \pm 0.012 & 0.71\end{array}$

(a) Regional sediments (1984).

(b) Fajarito Canyon snowmelt (1983). 
TABLE 1-i2. Radiochemtcal Analyses of Sediment and Runoff Samples from Area G (TA-54)

Sediments i0ctober 1,1984 )

\begin{tabular}{|c|c|c|c|c|c|c|}
\hline Station & $\begin{array}{l}137 \mathrm{cs} \\
(\mathrm{pc} / \mathrm{g})\end{array}$ & $\begin{array}{l}238 \mathrm{Pu} \\
(\mathrm{pCr} / \mathrm{g})\end{array}$ & $\begin{array}{c}239-240 \mathrm{Pu} \\
(\mathrm{pCl} / \mathrm{g})\end{array}$ & $\begin{array}{c}3 H \\
(p C 1 / g) \\
\end{array}$ & $\begin{array}{c}\text { Tota } 1 \\
\text { Uranium } \\
(\mu g / g) \\
\end{array}$ & $\begin{array}{c}\text { Gross } \\
\text { Ganma } \\
\text { (counts/min/g) }\end{array}$ \\
\hline 1 & $0.10 \pm 0.16$ & $0.002 \pm 0.004$ & $0.004 \pm 0.004$ & $1.9 \pm 0.8$ & $4.1 \pm 0.6$ & $8.2 \pm 0.6$ \\
\hline 2 & $0.17 \pm 0.13$ & $0.004 \pm 0.004$ & $0.005 \pm 0.003$ & $2.1 \pm 0.8$ & $\therefore .7 \pm 0.4$ & $5.9 \pm 0.6$ \\
\hline 3 & $0.34 \pm 0.18$ & $0.014 \pm 0.007$ & $0.011 \pm 0.006$ & $2.1 \pm 0.8$ & $3.5 \pm 0.5$ & $8.0 \pm 0.6$ \\
\hline 4 & $0.42 \pm 0.26$ & $0.015 \pm 0.006$ & $0.037 \pm 0.009$ & $3.8 \pm 1.0$ & $4.2 \pm 0.6$ & $9.0 \pm 0.6$ \\
\hline 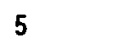 & $0.16 \pm 0.18$ & $0.002 \pm 0.005$ & $0.002 \pm 0.003$ & $4.7 \pm 1.2$ & $2.2 \pm 0.4$ & $3.9 \pm 0.3$ \\
\hline & $0.23 \pm 0.15$ & $0.029 \pm 0.010$ & $0.440 \pm 0.045$ & $3.0 \pm 1.0$ & $4.2 \pm 0.6$ & $8.9 \pm 0.3$ \\
\hline 7 & $0.21 \pm 0.14$ & $0.073 \pm 0.007$ & $0.214 \pm 0.024$ & $4.1 \pm 1.0$ & $2.2 \pm 0.4$ & $5.4 \pm 0.6$ \\
\hline 0 & $0.17 \pm 0.14$ & $0.036 \pm 0.009$ & $0.051 \pm 0.005$ & $1.8 \pm 0.8$ & $3.9 \pm 0.5$ & $7.9 \pm 0.6$ \\
\hline & $0.11 \pm 0.18$ & $0.032 \pm 0.008$ & $0.030 \pm 0.007$ & $2.7 \pm 0.8$ & $2.8 \pm 0.4$ & $4.4 \pm 0.6$ \\
\hline$x \pm 2 s$ & $0.21 \pm 0.21$ & $0.023 \pm 0.046$ & $0.088 \pm 0.295$ & $2 . \hat{y} \pm 2.1$ & $3.3 \pm 1.7$ & $6.8 \pm 3.9$ \\
\hline
\end{tabular}

Bisi-off in Area $G$ at Gaging Station

(Augusi 24, 1984)

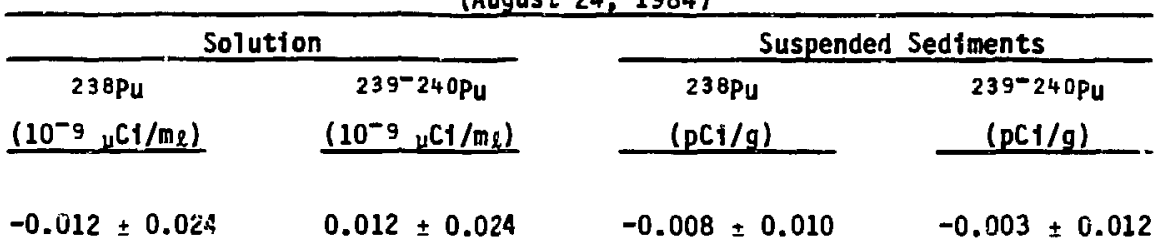

Note: The \pm value represents trice the standard deviation of the distribution of ${ }^{\circ}$ observed values. If only one analysis is reported, then the value represents twice tile uncertainty term for the analyis. 


\subsubsection{Waste Management Studies}

A variety of applied research has been under way at Los Alamos for several years addressing environmental conditions; ecological, geologic, and hydrologic properties and processes; equipment; packaging; methodology; and theoretical modeling relating to burial and transport of radioactive waste. These continuing studies are producing a growing body of knowledge about the subsurface disposal areas at Los Alamos.

\subsubsection{Area B Prerenovation Environmental Study}

Area $B$ is a shallow-land radioactive waste burial site west of $T A-21$ at Los Alamos. Alpha-contaminated and chemical wastes were deposited in shallow trenches from 1944-1948. The eastern half of Area B was ieft undisturbed for nearly 30 years, allowing invasion of native plant species. During the spring of 1982, a radioecological survey was done on the site before the vegetation was removed. The site was then covered with $1 \mathrm{~m}$ of compacted tuff and soil, topsoil was added, and the area reseeded in late summer of 1982.

Prior vegetation mapping (Tierney and Foxx 1982) of Area B showed the location of the major trees, shrubs, and other perennials of a ponderosa pine community. In the spring of 1982, sampling was done to characterize the rooting patterns of long-lived plants on the site, the temporal aspects of biointrusion of the plants, and the contributing processes to mineral cycling of radionuclides. Of particular interest was how these long-lived, deep-rooted trees and shrubs had interacted with burial wastes and whether the wastes were then translocated to surface plant parts. Initial studies at Area $B$ showed radioactivity levels sufficiently above background to permit determination of standing inventories and concentrations in root, stem, and leaf compartments of major plant species. In addition, the age and condition of the site provided a unique natural plant community in which to gather information relevant to current biointrusion issues regarding solid radioactive waste siting, maintenance, and closure. The site was divided into eight zones of $20 \times 50 \mathrm{~m}$. The zones were used for collection of vegetation and soils because of the heterogeneity of the plant communities. This approach allowed sampling of specific species 
predominant in different zones. In addition, five ponderosa pines (Pinus ponderosa), an elm (U1mus parvifolia), peach (Prunus spp.) chamisa (Chrysothamnus nauseosus), and Apache plume (Fallugia paradoxa) were excavated to stoudy rooting characteristics and to determine if they indeed had grown into plutonium-contaminated waste. One large ponderosa (27 years $01 \mathrm{~d}$ ) had grown into a small pocket of plutonium-contaminated waste about $1 \mathrm{~m}$ below the surface. This tree, as well as the others excavated, was extensively sampled above and below ground.

The samples from the 27-year-old ponderosa and others selected from the zone sampling were analyzed radiochemically for plutonium, uranium, cesium, and scandium. Fourteen sample types were analyzed. Leaf and needle samples in some cases were collected from the top, center, and lower part of the trees to determine if dust loading on these surfaces changed with height. Bransisas were also covered with plastic bags and transpirate samples taken to determine tritium concentrations. Tritium (as HTO) is highly mobile in the environment and is considered a tracer for water movement through waste. Sample preparation for leaves and needles required calculation of the sample surface area, wet weight, dry weight, and ash weight. Root and bole samples were divided into two samples, exterior bark and interior $x y l e m$, by carefully removing the bark without cross-contamination to the xylem. Determination of the plants' exterior contamination versus interior root uptake contamination was necessary to establish the method of entry to the plant and hence mineral cycling pathway involved. Plutonium-239, uranium, and $137 \mathrm{Cs}$ concentrations ranged six orders of magnitude depending on the species and sample type.

In 1981 Dreicer studied the physical transport of soil and, therefore, contaminants attached to the soil onto vegetative surfaces berause of raindrop splash. Soil accumulation by tomato plants (Lycopersicon esculentum) was investigated as a function of soil particle size, rainstorm characteristics, height of foliage, surface area, and canopy cover of the plants. Data from this study provide evidence that a significant fraction of the surficial contamination of foliage may be attributed to the rain splash mechanism.

The results of Area B and Dreicer (1981) studies were used to validate the radionuclide transport portion of the BIOTRAN model and to develop 
improved sampling and data interpretation methods for environmental surveillance at Los Alamos.

\subsubsection{Comprehensive Environmental Assessment and Response Program}

The Environmental Surveillance Group (HSE-8) is undertaking a major task called the Comprehensive Environmental Assessment and Response Program (CEARP) for the DOE's ATbuquerque Operations Office (ALO). The objective of this project is to implement a phased program to identify, assess, and correct potential environmental problems covered by yaricus federai/DOE laws and regulations. Particular emphasis will be on problems associated with radioactive and nonradioactive hazardous and toxic substances, subject to the Comprehensive Environmental Response, Compensation, and Liability Act. ("Superfund Law"). Site characterization activities at Los Alamos will involve review of historical documentation and interviews with past operators, detailed site sampling and analysis, and remedial action if necessary. CEARP will include reviews of the practices for handling and disposing of mixed wastes.

\subsubsection{Shallow Land Burial Studies}

Long-term waste management alternatives for the buried and retrievably stored wastes in various locations at Los Alamos (Walker et al. 1981) have been evaluated. The environmental consequences, economic costs, and radiological risks to the public and workers were estimated for the continued fresent practices, added engineered containment for the inactive sites, and selective TRU retrieval alterratives. For each major alternative, several options were evaluated for resistance to natural phenomena, accidental release of the buried waste, and long-term monitoring requirements. The analysis addressed the inactive sites as well as the currently used disposal sites.

The burial of wastes, followed by covering tine material with uncontaminated earthen backfil1, provides for physical isolation of the waste from the environment. For the wastes to enter the environmerit, some transport process must occur. The transport mechanism of greate: potential concern is the movement of precipitation (rain or snow) into the 
waste and subsequent leaching of the radionuclides into ground or surface waters. This has led to considerable study of hydrologic transport processes within and adjacent to waste disposal sites at Los Alamos.

Several investigations have shown that very little of the approximately $40 \mathrm{~cm} /$ year (16 in./year) precipitation at Area $\mathrm{G}$ enters the waste material. The bulk of the precipitation either runs off immediately or is held in the upper few meters of the surface material. The eastern part of Mesita del Buey (Area G) is underlain by about $75 \mathrm{~m}$ of unsaturated tuff and the western part by about $180 \mathrm{~m}$ (Purtymun and Kennedy 1971). The surface of the mesa is about $30 \mathrm{~m}$ above the adjacent canyons. These canyons are floored with alluvial material deposited, in part, by ephemeral streams that flow only after major precipitation or snowmelt events. Saturated zones are present to a limited extent in the alluvium, recharged by precipitation and stream flow.

The regional ground water aquifer is in sediments located beneath the tuff, at depths of about $300 \mathrm{~m}$. There is no evidence of recharge to this aquifer, or to perched water in streambed alluvium, from precipitation that might enter the waste material (Section 1.1).

Measurements at monthly intervals, utilizing neutron moisture probes in 10 access holes in the fill (unconsolidated tuff) overlying disposal areas and in the adjacent tuff, show that precipitation moisture penetrates no more than about $5 \mathrm{~m}$ below the surface, with no significant changes in moisture content at depths greater than about $8 \mathrm{~m}$ for both the fill and tuff (Wheeler, Smith, and Gallegos 1977). Below that depth, moisture contents are in the range of $1-5 \%$ by volume. At this water content, moisture movement occurs principally as vapor diffusion. Only contaminants that are present as gases or volatile liquids may be transported by diffusion of water vapor.

Previously, waste materials containing tritium were placed in both pits and shifts at Los Alamos. Now tritium disposal is restricted to shafts and requires that special containment be used to restrict movement of tritium gas or tritiated water vapor away from the shafts. Investigations at the disposal area have described the distribution of tritium within an area occupied by several disposal shafts (Purtymun 1973, Wheeler and Warren 1975). It was shown that tritium was moving away from some older shafts through the tuff, primarily through zones of higher porosity, 
through open fractures, and along interfaces between ash flows. The tritium concentrations in the soil moisture immediately adjacent to the shafts were higher than that allowed for public ground or surface water suppiies. However, the slow rate of movement away from the shafts (allowing for decay of the tritium) and dispersion within the tuff reduced those concentrations to below maximum permissible concentrations within the upper few meters of the surface. Some tritium diffuses into the atmosphere. Tnitium air sanplers are operated continuously within the disposal area. Data from these samplers indicate air concentrations higher than normal background but at less thai $1 \%$ of the concentration guide for uncontrolled areas (Section 1.3.3). The studies also indicated that there was virtually no downward movement of tritium below about $20 \mathrm{~m}$.

In an effort to determine if any leaching below the buried LLW occurred, core samples were removed from beneath one of the older disposal pits at Area $G$ by drilling five horizontal holes into the canyon wall adjacent to the mesa top (Purtymun, Wheeler and Rogers 1978). Analyses of samples from these cores showed gross alpha and gross beta values within the range expected of normal uncontaminated soil materials. Further analyses of $90 \mathrm{Sr}, 137 \mathrm{Cs}, 238 \mathrm{Pu}, 239 \mathrm{Pu}$, and $24 \mathrm{Am}$ produced results that were below detection limits for all samples. Analyses of the cores indicated natural uranium concentrations that were indistinguishable from the natural uranium content of the Bandelier Tuff elsewhere. Thus, there was no indication of any radionuclide migration within a few meters of the bottom of the pit.

Estimates of the rate of erosion of Mesita del Buey over the last million years indicate that exposure of the waste by vertical erosion may occur within 50,000 years (Wheeier, Smith, and Gallegos 1977). Lateral erosion of the sides of the mesa may expose waste in the pits closest to the mesa edge in approximately 100,000 years. The average plutonium concentration in all the pits is presently at or below the $100 \mathrm{nCi} / \mathrm{g}$ maximum permittea for burial and will be reduced by a factor of 2 to 4 before exposure.

Los Alamos has initiated a number of studies to systematically field test three essential components of shallow land burial (SLB) systems-biointrusion barriers, migration barriers, and water management systems-and, when these individual components are tested, to design, construct, and field test complete integrated systems for arid SLB combining the individual components that have been previously tested. In addition, the data 
obtained are used to help validate the unsaturated transport model, TRACR3D; a surface run-off model, CREAMS; and an environmental assessment mode 1, BIOTRAN.

Los Alamos has demonstrated that the physical, hydrologic, and erosion processes at a burial site (Figure 1.19) are strongly interdependent and cannot be treated as separate problems.

1.3.5.3.1 Biointruston Barrier Testing. Questions concerning the performance of different types of biobarriers at various field scales and the effects of layered-rock barrier systems on the water balance are being addressed in a field experiment at Area $G$.

Three types of 1-m-thick biobarriers are being tested in the Area $G$ experiments in 6- by $21-\mathrm{m}$ plots: 1) 15-cm gravel (1-2-cm diameter) on top of $85-\mathrm{cm}$ cobble (7.5- to 12-cm diameter), 2) 1-m coubble, and 3) $30-\mathrm{cm}$ gravel on top of $70-\mathrm{cm}$ cobble. These three treatments are being compared with the conventional trench cap treatment containing 1 m of crushed tuff without a biobarrier. Only $15 \mathrm{~cm}$ of topsoil over these four field treatments were used to ensure that percolation of water through the biobarriers

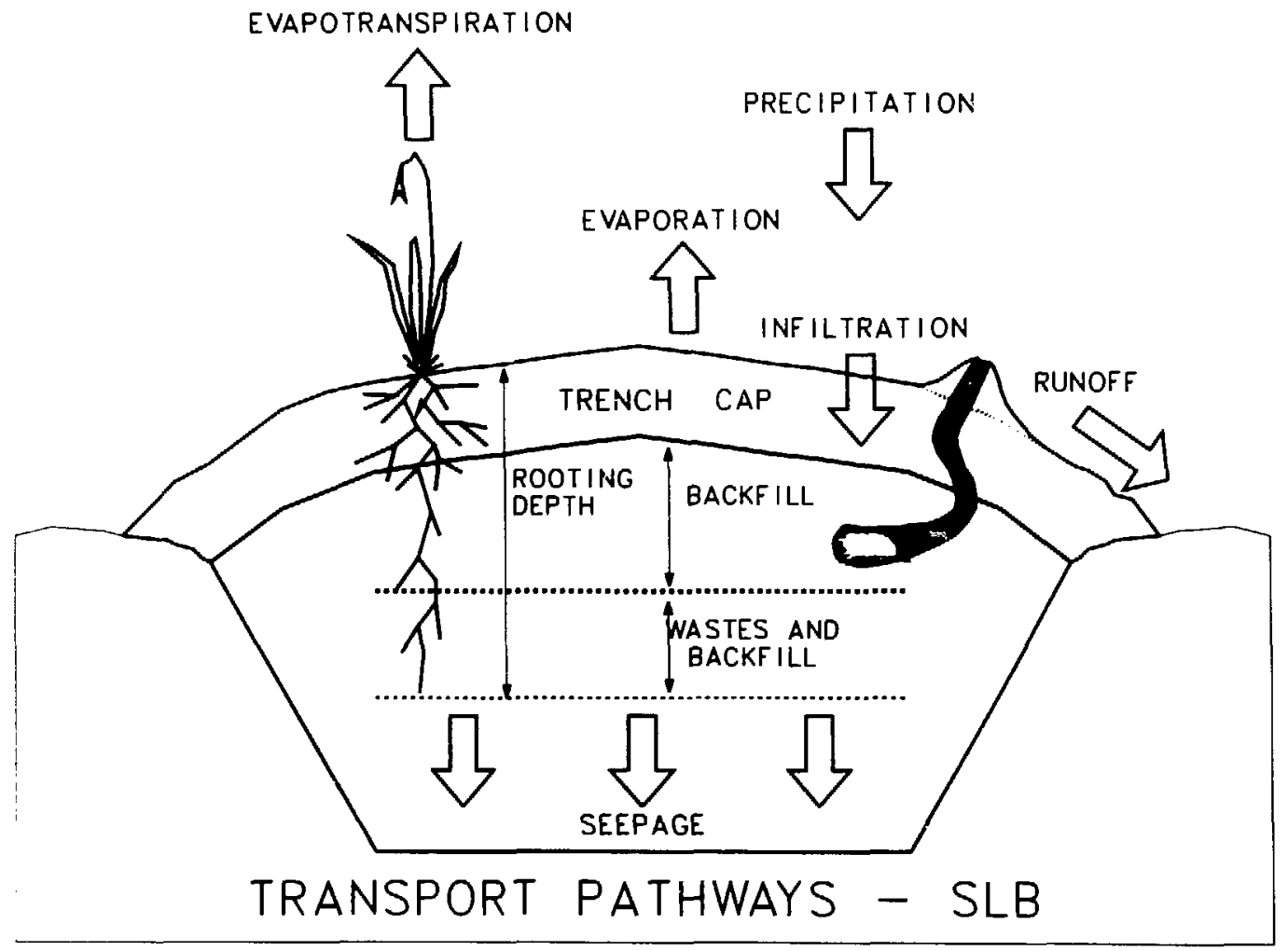

FIGURE 1.19. Hydrology of Shallow-Land Disposal of Radioactive Wastes. 
would be detected using neutron moisture gauge techniques. A cesium chloride tracer layer was emplaced immediately beneath each biobarrier land at a corresponding depth in the conventional cap treatment) so that the penetration of roots currently growing through the biobarriers can be detected by collecting plant samples and assaying them for their cesium content.

Cesium determinations were performed on native grass vegetation samples collected from all four plots at Area $G$ on 14 sampling dates (June 1982 through November 1983). Elevated levels of cesium were generally not found in these samples, indicating that the biobarriers were performing satisfactorily. However, only the 1-m cobble biobarrier proved to be totaliy effective in preventing root penetration to the cesium tracer. The grave1-cobble intrusion barriers failed once for the 15-cm grave1--85-cm cobbie treatment and three times for 30-cm grave1--70-cm cobble treatment. The crushed-tuff treatment failed four times during this 1-1/2-year period and demonstrated a sigrificantly higher average cesium concentration in the vegetation from this plot than for similar samples collected on the other three treatments.

The water content of the crushed tuff located $30 \mathrm{~cm}$ beneath the four biobarriers is shown as a function of time in Figure 1.20, along with daily precipitation and snow depth (Hakonson 1985). The most obvious characteristic of this data is the seasonal changes in water content, regardless of the overlying trench cap treatment. The greatest iricreases in water content occurred with winter snowmelt, with smaller increases occurring when rain was the source of precipitation during seasons when evapotranspiration was maximized.

The three biobarrier treatments involving gravel and cobble demonstrated higher water content values (30 cm beneath the biobarrier) with time than similar values for the crushed-tuff treatment (Figure 1.20). This observation reflects the loss-of-water storage capacity in the 1-m-thick layer of gravel and/or cobble that would otherwise be present in the corresponding 1-m-thick layer of crushed tuff in this experiment. This loss-of-water holding capacity can obviously result in significantly greater percolation of precipitation and, concurrently, more rapid changes in soil water content.

Questions concerning the performance of biobarriers at different field scales and the effects of layered rock barrier systems on water balance are 

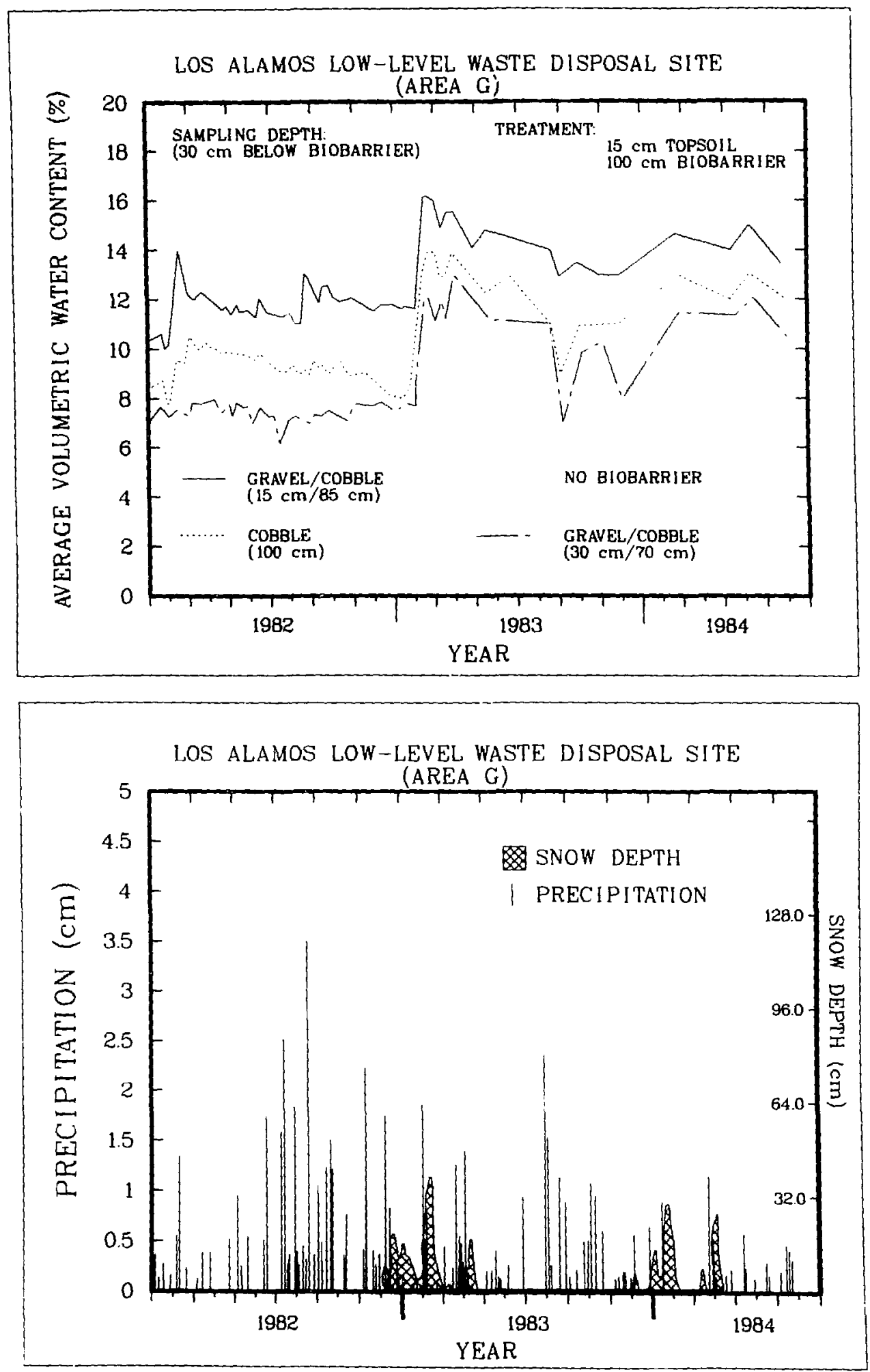

FIGipe 1.20. Precipitation and Distribution of Water $30 \mathrm{~cm}$ Beneath the Biobarrier Treatments at Area $G$ vs Time. 
being addressed simultaneously in two separate biobarrier experiments. An intermediate-scale experiment is under way in two caissons $13.03-m$ diameter, 6.1-m deep), while a large-scale study plot has been included in a new cover system applied to Area B.

In the caisson study, one caisson received a conventional trench cap profile, in which the caisson was filled with crushed tuff, a layer of cesium, strontium and cobalt, $1 \mathrm{~m}$ of crushed tuff and $60 \mathrm{~cm}$ of topsoil. Another biobarrier treatment was emplaced in a second caisson, which was filled the same as the first caisson, except that the trench cap consisted of $70 \mathrm{~cm}$ of cobble (7.5- to $12.7-\mathrm{cm}$ diameter) overlain by $25 \mathrm{~cm}$ of gravel (2-cm diameter), covered by $60 \mathrm{~cm}$ of topsoi1. To determine the response of these two designs to excess soil moisture, both treatments received supplements to natural precipitation, amounting to a total annual water input of 75-100 cm, and were monitored for soil water content and plant uptake of cesium.

During the 17 months for which data are available, about $30 \%$ of the 76 plant samples growing on the conventional trench cap were found to contain elevated cesium levels. Only $24 \%$ of the plant samples collected from the caisson with the biobarrier contained elevated cesium concentrations, and the overall mean cesium concentration of these samples was about a third of those measured in the other caisson. Thus, although both trerch cap designs failed in preventing root penetration, the gravel-cobble biobarrier did reduce the cesium concentrations occurring in the plants.

The caisson soil water content of the topsoil is shown in Figure 1.21 and can be compared to the precipitation (Hakonson 1985). The topsoil water content values for the biobarrier treatment averaged several per cent higher than for the soil/ crushed-tuff trench cap. This difference stems from the fact that the porous materials above the gravel-cobble biobarrier act as a capillary barrier, which results in slower infiltration of water through the upper portions of this trench cap, with subsequent surges of water flow occurring once the layers above the rock barrier attain a high water content value.

The Area B biobarrier experiment consisted of emplacing two surface treatments. The conventiona? trench cap design consisted of about $75 \mathrm{~cm}$ of 

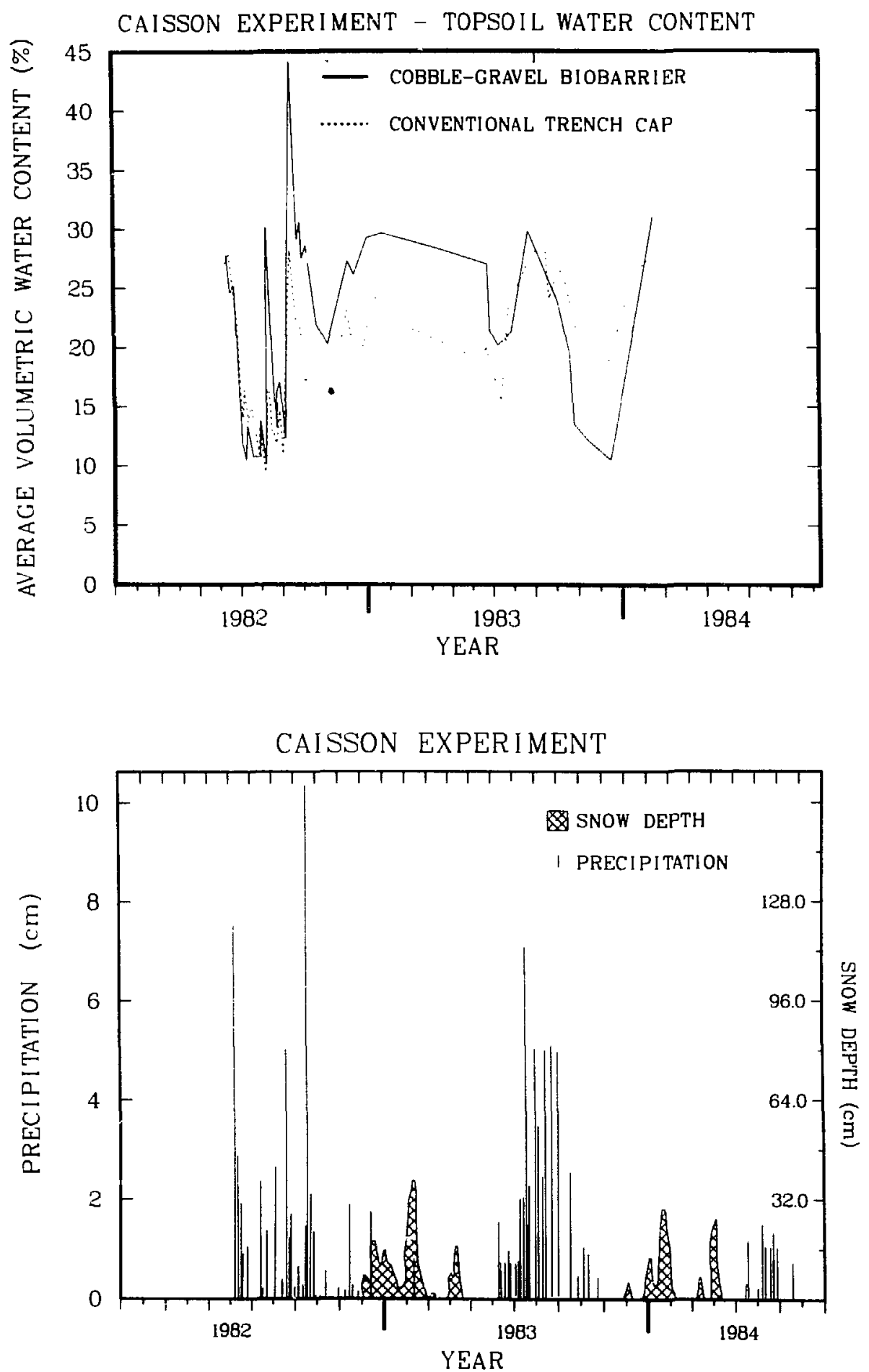

FIGURE 1.21. Soil Water Content and Precipitation Data from Caissor Experiment. 
crushed tuff overlain by $15 \mathrm{~cm}$ of topsoil. The biobarrier treatment consisted of a $100-\mathrm{cm}$ grave1-cobble layer overlain by about $60 \mathrm{~cm}$ of topsoil. Both trench caps received an application of cesium tracer on the original trench cap surfaces and were monitored for plant cesium uptake and soil water content.

None of the plant samples collected in 1983 on either trench cap treatment at Area B contained elevated concentrations of cesium. These data indicate that both trench cap configurations were effective in preventing root access to the tracer layer.

The soil water content in the topsoil and beneath both trench caps at Area $B$ is shown as a function of time in Figure 1.22. Values of soil water content in both sampling locations exhibited the same treatment effect observed in the caisson study; $i$.e., large soil water content values were found in the topsoil above the biobarrier, as well as in the backfill beneath the biobarrier. The data presented in Figure 1.22 also suggest that snowmelt significantly contributes to soil moisture recharge.

1.3.5.3.2 Migration Barrier Testing. Migration barriers are used in shallow land burial facilities to slow or stop the movement of water and contaminants and are discussed in a recent Los Alamos report as a single component embedded in a complex environmental system (Lane and Nyhan 1985 ).

Although not much is known about gravel-cobble biointrusion barriers functioning as a subsurface wick or capillary barrier system in a trench cap, field research at Los Alamos has shown that gravel-cobble biobarriers can have an effect on the subsurface migration of water and radionuclides (Travis 1984). Migration barrier testing was performed in two 6.1-m-deep caissons with a diameter of $3.05 \mathrm{~m}$, one of which contained a 1-m-thick gravel-cobble biobarrier (Figure 1.23). In the caisson without a barrier, soil water movement at the zone containing cesium, strontium, and cobait tracers did not occur as sudden breakthrough surges, as it did in the caisson with the biobarrier. For the same water inputs, the biobarrier treatment exhibited greater migration of tracers than did the tuff treatment, as is typically shown for the cobalt data (Figure 1.24). This effect was 

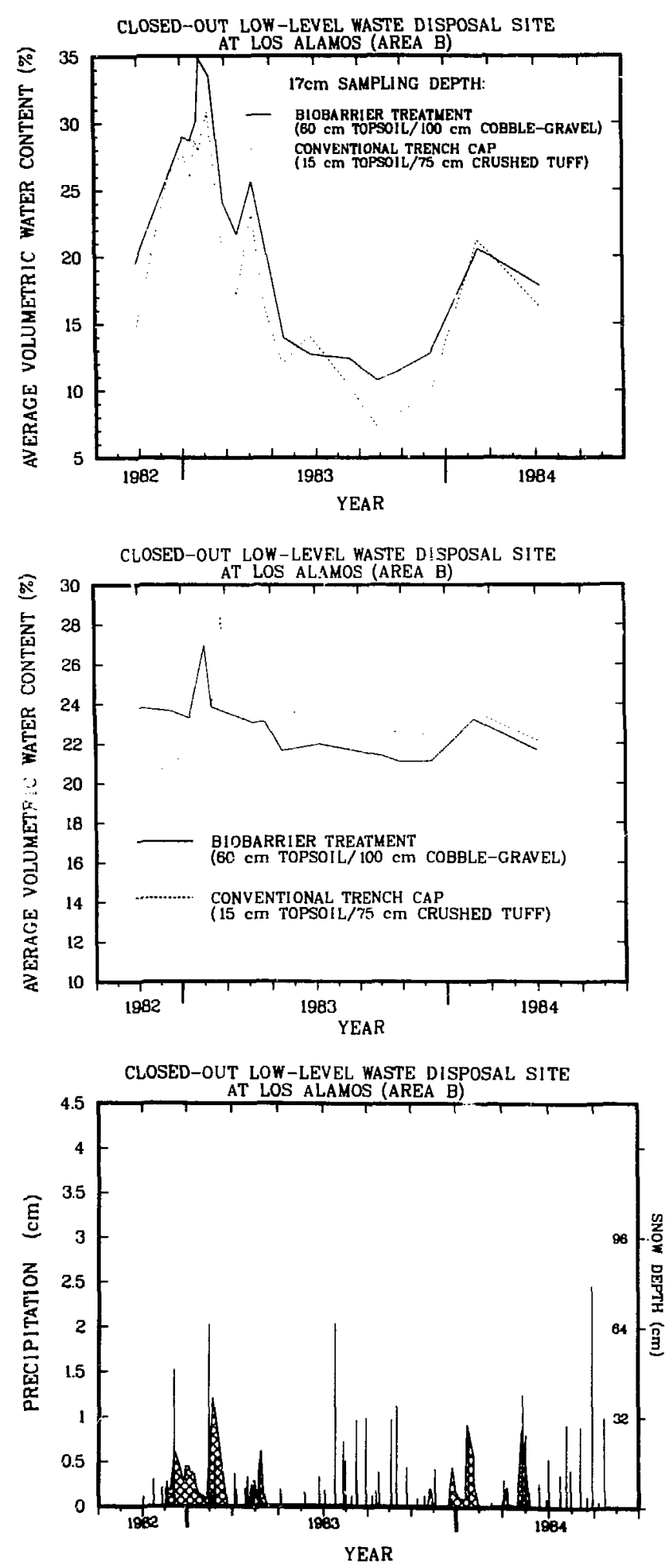

FIGURE 1.22. Soil Water Content and Precipitation Data from Area B Experiments. 

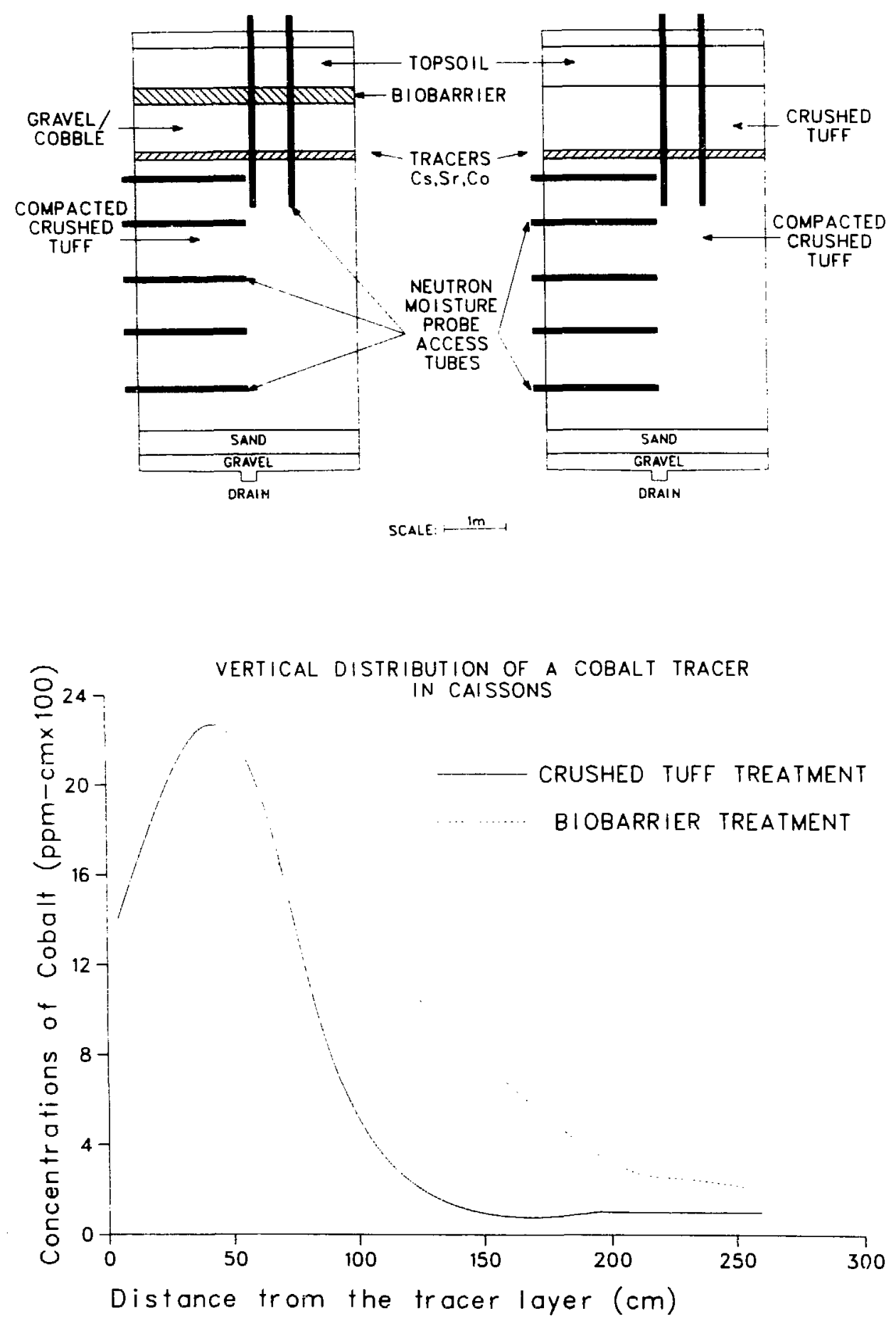

FIGURE 1.24. Vertical Distribution of a Cobalt Tracer in Caissons. 
attributed to greater nonuniformity in water content, more water infiltration, and the "pulse" type of change in water content at or near the tracer layer in the biobarrier treatment compared with the tuff treatment.

Thus, a gravel or cobble layer incorporated into the cap may result in water pulse problems if the soil in the region adjacent to the gravei becomes saturated. This may be solved by perforated pipes and pumps emplaced strategically beneath the trench cap. Another solution would be to make certain the layer above the gravel-cobble layer performed as a satisfactory wick layer. This would mean that a gravel-cobble layer in the trench cap would have a significant slope (the slope in the caisson experiment shown in Figure 1.23 is equal to zero! and slope length and that the thickness of the overlying capillary layer would also be adequate in this configuration to effectively transmit subsurface water.

1.3.5.3.3 Ground and Surface Water Management Systems. Sma11-scale modeling has demonstrated it is possible, by using capillary barriers, to maintain dry structure in porous media. The percolating liquid will only penetrate the coarser material after the overlying finer material is near saturation, provided the soil moisture characteristic curves of the two materials reach a certain degree of dissifilarity. Consequently, the structure, which is enclosed in the coarser material, remains dry. As long as the pressure at the coarse/fine interface remains negative, water infiltrating into the finer layer will not cross the interface but will flow within the finer layer; percolation occurs where the saturated water front reaches the edge of the coarse layer. The limiting granulometric differences, beyond which this phenomenom ceases to exist, have been determined. This concept has sometimes been referred to as the "wick effect." It was found that under unsaturated conditions, a gravel lens caused lateral flow in a finer-textured overlying material. The lateral distance over which the water can be transported is 1 imited and will be influenced by the slope of the interface.

At equal matric potentials, a fine-grained medium will contain more water than a coarse-grained medium. During drainage, an initialiy saturated soil will drain its largest pores first. In wetting a dry soil, the smallest pores will fill first as the matric potential is allowed to increase (getting less negative). During wetting, the water content 
increases as progressively larger pores are filled. This will be accomplished by an increase in hydraulic conductivity and lateral diversion of water already promoted by the presence of a sloping interface. The coarser medium, however, with its predominantly large pores, will remain relatively dry with a low hydraulic conductivity until the matric potential reaches zero and near zero at the interface (Figures 1.25 and 1.26). The system will fail when or before the matric potential at the interface ceases to be negative. Point readings at the interface are provided through tensiometers. Proximity of the failure point to zero will be the function of abruptness and magnitude of particle size lifference at the interface.

The wick system designs indicate that an effective wick system is one in which the suction at the wick interface is about 4-kPa tension or less before failure. To obtain such a luw suction between backfill and sand, the addition of a small amount of bentonite to the backfill materials at the land disposal site is necessary (Figure 1.27).

1.3.5.3.4 Erosion Control Technology. Trench covers used for shallow land burial of low-level radioactive wastes are exposed to a very dynamic environment and must isolate waste under harsh temperature regimes, dramatic changes in plant and animal species composition as natural succession occurs, and extreme conditions of wetting and drying. Failure to perform in any of these areas can result in the failure of engineered barriers within the cover, excessive erosion of the cover soil, excess percolation of water into the trench, plant and animal intrusion, and immobilization of the waste. Under these constraints, it is not surprising that the most frequent failure mode at existing LLW sites in the US involves processes interacting with the trench cover (Hakonson et al. 1982). Fortunately, the accessibility of the trench cover facilitates required remedial action to correct contamination problems, in direct contrast to correcting problems arising from ground water contamination.

Erosion control plots were exposed to simulated rainfall events to generate infiltration, runoff, and erosion as previously described (Nyhan 1983b, 1984).

Four treatments were imposed on the eight erosion plots. Two plots received a new up-and-down slope disking (cultivated treatment). Both standard tilled plots were thus again comparable with the standard 


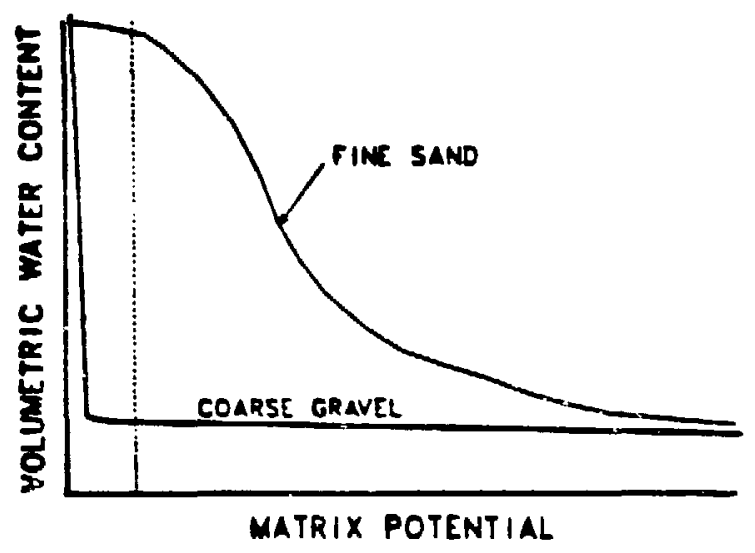

FIGURE 1.25. Hypothetical Wetting Curve for a Fine Sard and a Ccarse Graval.

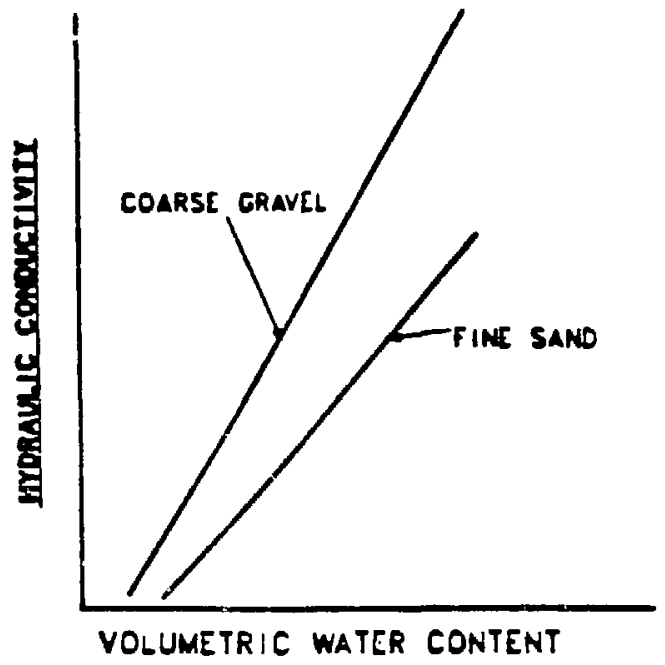

FIGURE 1.26. Hypothetical $K(\theta)$ Curves for a Fine Sand and a Coarse Gravel.

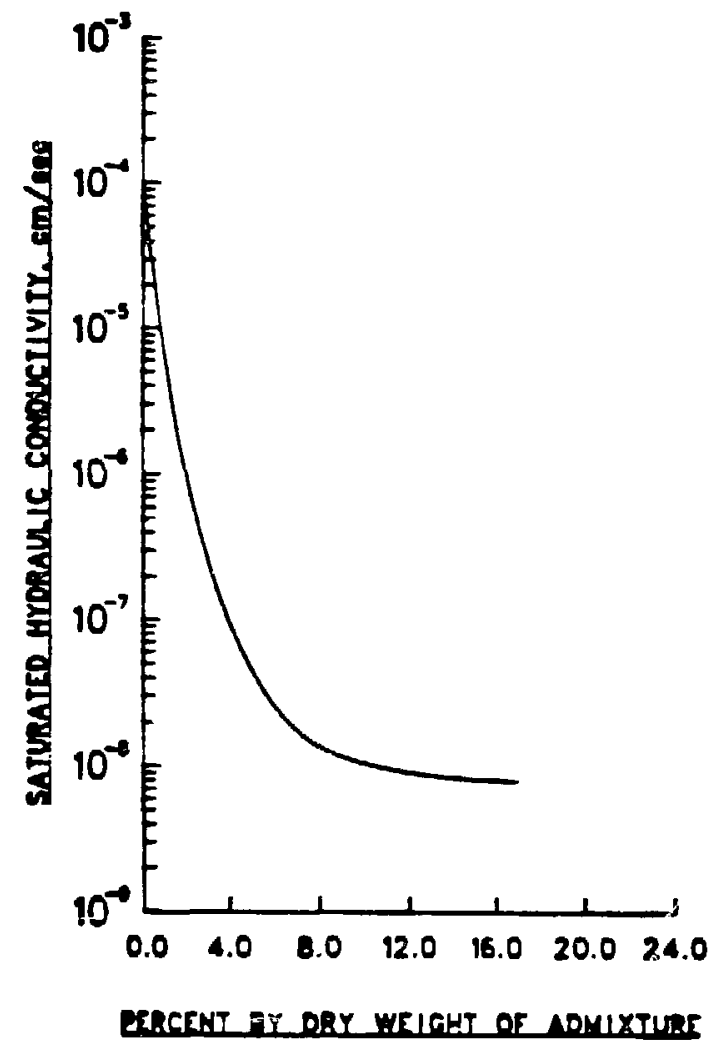

FIGURE 1.27. Effect of Adding Bentonite to Los Alamos Tuff. 
Universal Soil Loss Equation (USLE) plot used to determine the soil erodibility factor. A second year's data were collected on the two plots that were not tilled in 1982 and had no vegetative cover (bare soil treatment). To determine the influence of partial gravel covers on soil erosion, two plots were prepared as the bare soil treatment and then received a gravel (<13-mm diameter) cover at an application rate of 60 tons/acre (gravel cover treatment). The influence of partial gravel covers plus vegetation on soil erosion was determined on two plots that were first seeded with western wheatgrass (Agropyron smithii), which then received the same gravel application rate as the gravel cover treatment (gravel and plant cover treatment).

Hydrograph, sediment concentration, and sedigraph data are presented in Figures 1.28 through 1.31 for typical rain simulator runs on the trench cap with cultivated, bare soil, gravel cover, and gravel and plant cover treatments.

During the three rain simulator runs on the cultivated plot (Figure 1.28), maximum discharge rates ranged from 3795 to $3978 \mathrm{~mm} / \mathrm{min}$, and maximum sediment concentrations from 6.3 .6 to $75.5 \mathrm{~g} \mathrm{~L}^{-1}$ were observed. Maximum sediment loss rates for the three simulator runs on this plot ranged from 2210 to $2476 \mathrm{~g} \mathrm{~min}^{-1}$. In contrast to the cultivated treatment, sediment concentrations observed ir. the bare soil plot usually ranged from only 30-50 $\mathrm{g} \mathrm{L}^{-1}$ (Figure 1.29).

The plots with gravel cover exhibited maximum sediment concentrations and loss rates that were 13 to 24 times smaller than on the plots with the cultivated treatment (Figures 1.30 and 1.31). The hydrograph data from these plots showed a marked delay in the amount of time it took until runoff ceased in comparison with the other treatments. A series of gravel dams located along the entire length of the erosion plot prolonged the length of runoff occurring on these plots to 8 to 14 minutes after the end of the simulated rainfall (Figures 1.30 and 1.31). Because the wheatgrass was only about 30 days old at the time of the August 1983 simulator runs, very little difference was expected or observed in the hydrograph and sedigraph results between the two treatments containing a surface application of gravel.

The hydrograph and sedigraph data for the dry, wet, and very wet soil surface simulator runs were integrated over time, and the average run-off 


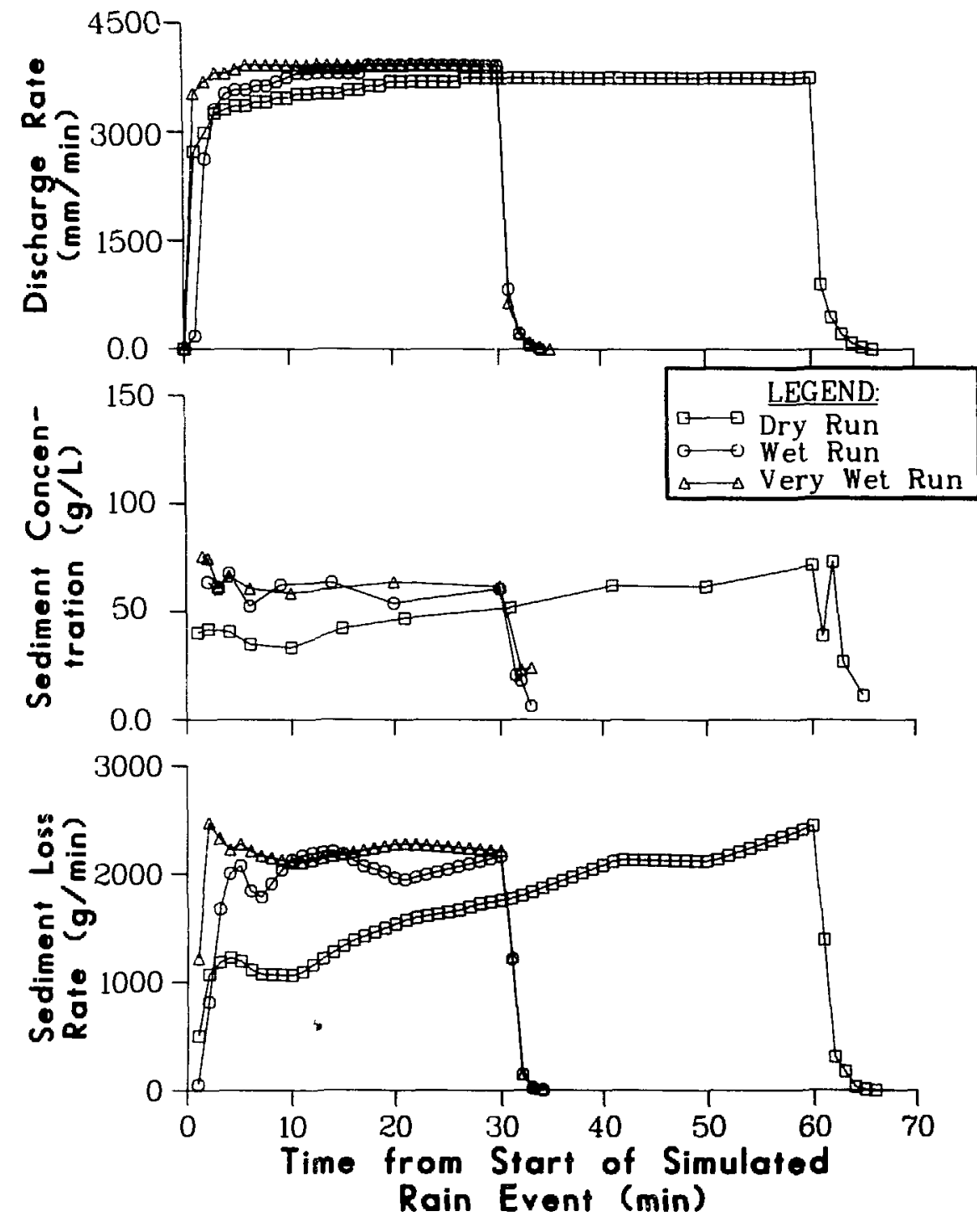

FIGIRE 1.28. Hydrograph, Sediment Concentration, and Sedigraph Data Collected in 1983 from Plot 8 with Cultivated Treatment. 


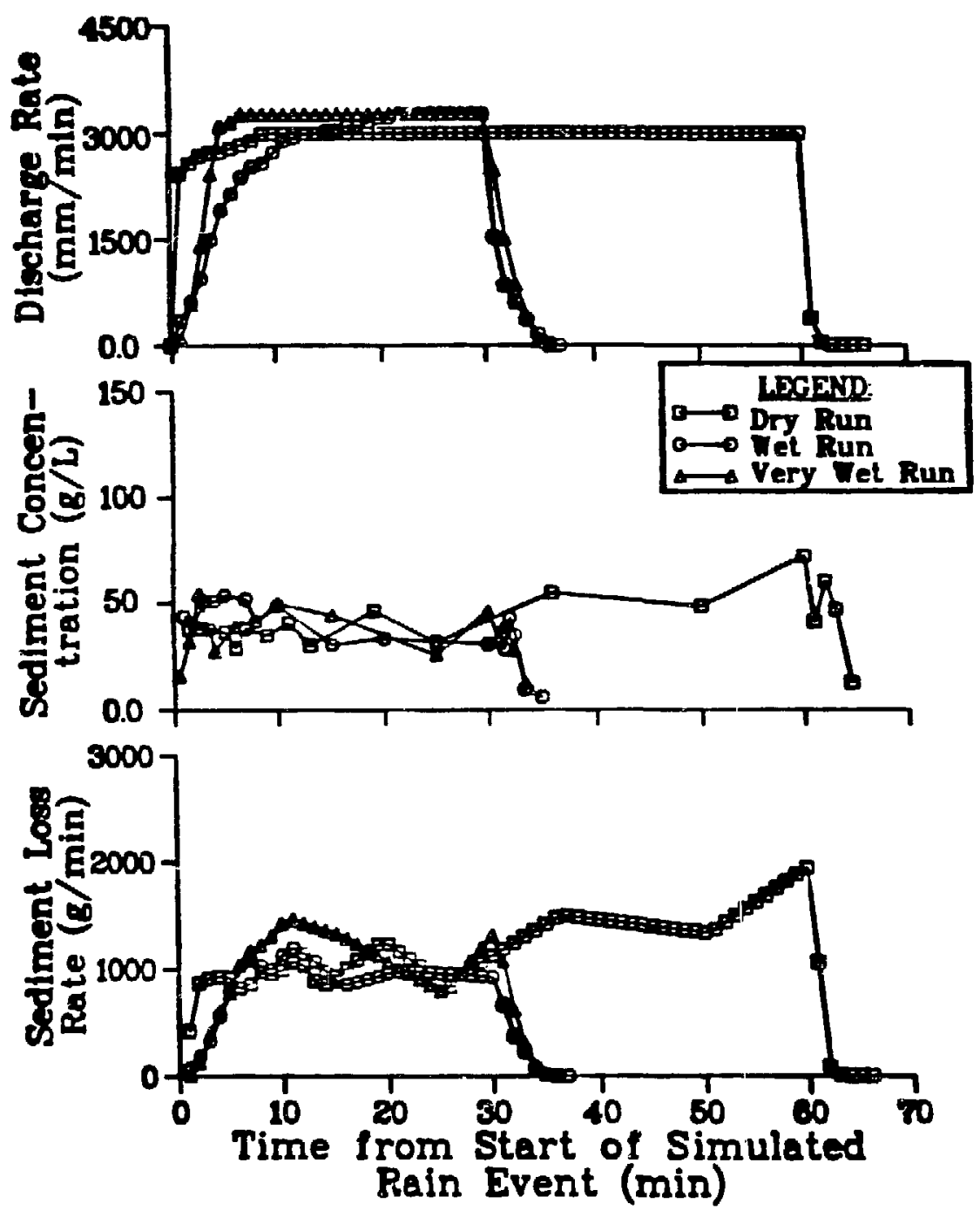

FIGURE 1.29. Hydrograph, Sediment Concentration, and Sedigraph Data Collected in 1983 from Plot 3 with Bare Treatment. 


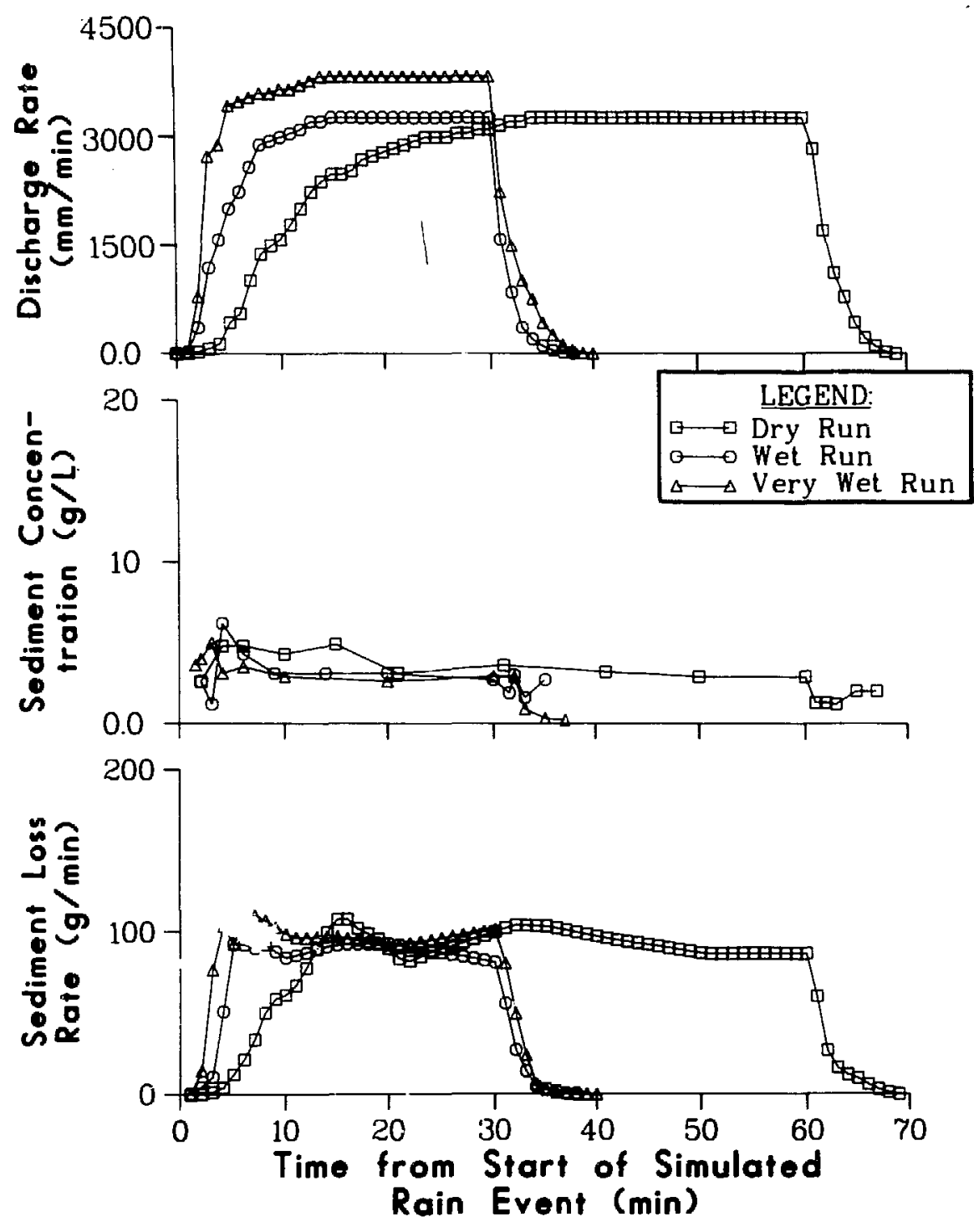

FIGURE 1.30. Hydrograph, Sediment Concentration, and Sedigraph Data Collected in 1983 from Plot 7 with the Gravel Cover Treatment. 


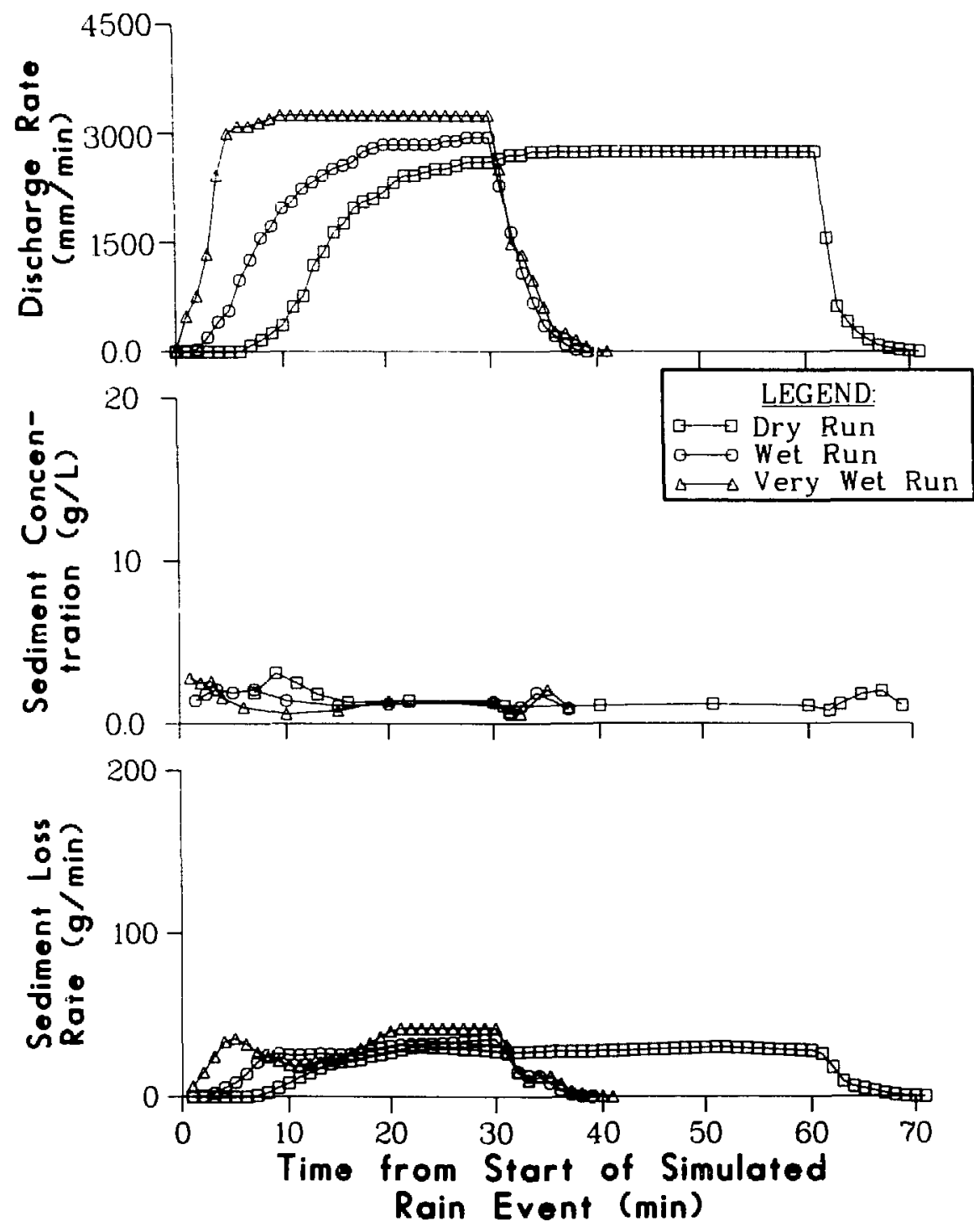

FIGURE 1.31. Hyơrograph, Sediment Concentration, and Sedigraph Data Collected in 1983 from Plot 5 with Gravel and Wheatgrass Cover. 
and soil loss amount for each surface treatment are shown in Table 1-13. An average of $60.4 \mathrm{~mm}$ of runoff occurred on the two erosion plots with the cultivated surface treatment, resulting in a runoff/precipitation ratio of 0.99 and a total soil loss of $96 \mathrm{~kg}$ for the dry-soil-surface simulator run (Table 1-13). Similar run-off/precipitation ratios were observed on the wet and very wet soil surface simulator runs on these plots, as well as for most of the other surface treatments. The only exception to this trend occurred on the dry and wet rain simulator runs on gravel and gravel plus wheatgrass treatments, in which average run-off/precipitation ratios ranged from 0.80 to 0.85 . Thus, the effect of the grave 1 on these two surface treatments dramatically reduced the amount of soil from the erosion plots but increased the amount of precipitation that infittrated the trench cap surface.

The values for the soil erodibility factor $(K)$ were calculated from the 1983 soil losses on both cultivated erosion plots and the intensity of the simulated rainstorms that were applied to these plots. The $K$ values determined from the 1983 rain simulator runs $10.069 \mathrm{MG}$. ha $\cdot \mathrm{h} \cdot \mathrm{ha}^{-1} \mathrm{MJ}^{-1}$ $\mathrm{mm}^{-1}$ ) agreed with similar data collected in 1982 (Nyhan 1984).

Estimates were calculated of the cover management factor, which reflects the soil loss ratio of the soil loss from a plot with a certain amount of gravel and/or plant cover to the corresponding loss from the clean-tilled, unprotected soil of a unit standard (Universal Soil Loss Equation) plot (Table 1-14). Soil loss ratios ranged from 0.040 to 0.050 for the trench cap plots with gravel cover and from 0.016 to 0.048 for the plots with a cover of gravel plus wheatgrass. The gravel and plant cover estimates responsible for these reductions in soil loss are also presented in Table 1-14, which demonstrates that gravel cover estimates ranged from 70 to $75 \%$, with the young, small wheatgrass plants contributing very little additional cover in the two plots with the gravei plus wheatgrass cover.

These soil loss ratio values are generally slightly lower than standard soil loss ratios observed in other field studies for gravel and mulch covers with this amount of ground cover (Hishmeier 1978).

Because the hydrologic processes at the surface of a SLB trench cap influence the management of the subsurface hydrologic processes, the soll water content beneath the erosion plots was monitored. Soll water 
TABLE 1-13. Average Run-off, Run-off/Precipitaton Ratios, and Soil Loss for Rain Simulator Runs Performed in 1983 on Dry, Wet, and Very Wet Soil Surfaces on Erosion Plots as a Function of Surface Treatment (a)

Average Run-off

$\frac{(\mathrm{mm})}{\text { Dry Wet Very Wet }}$

Treatment

(No. of Plots)

\begin{tabular}{cc}
\multicolumn{2}{c}{ Average Run-off/ } \\
Precipitation Ratios \\
\hline Dry Wet $\quad$ Very Wet
\end{tabular}

surface Surface surface

0.99

0.90

0.99

0.79

0.84

28.3

Gravel (2)

Gravel Plus

Wheatgrass (2)

$\begin{array}{lll}60.4 & 28.0 & 30.7 \\ 51.1 & 23.6 & 27.2 \\ 46.2 & 23.3 & 28.3\end{array}$

29.0

0.82

0.85

0.99

0.99

0.92

0.97

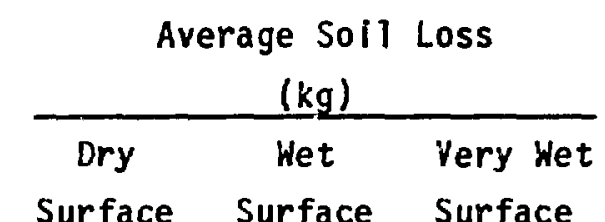

(a) Represents an initial 60-min rainfall simulation (dry surface), a 30-min run 24 h later (wet surface), and another 30-min run after a 30-min delay (very wet surface), all performed at a nominal target rainfall rate of about $60 \mathrm{~mm} \mathrm{~h}^{-1}$. 
TABLE 1-14. Soil Loss, Cover Management Factor (C), and Gravel and Plant Cover Estimates for the Trench Cap Plots with Gravel and Gravel Plus Wheatgrass Cover (1983) Data

\begin{tabular}{|c|c|c|c|c|}
\hline $\begin{array}{l}\text { Plot } \\
\text { Number }\end{array}$ & $\begin{array}{l}\text { Total Soil Loss }(a) \\
\mathrm{Mg} \mathrm{Ha}{ }^{-1} \\
\end{array}$ & $\underline{C \text { Factor }}^{(\mathrm{b})}$ & $\begin{array}{c}\text { Gravel } \\
\text { Cover } \\
(\text { q) }\end{array}$ & $\begin{array}{l}\text { Plant } \\
\text { Cover } \\
(z) \\
\end{array}$ \\
\hline & Trench $\mathrm{Ca}$ & with Gravel & & \\
\hline 2 & 3.71 & 0.040 & 75 & 0.0 \\
\hline 7 & 4.66 & 0.050 & 71 & 0.0 \\
\hline
\end{tabular}

Trench Cap Plots with Gravel Plus Wheätgrass Cover

$\begin{array}{lllll}4 & 4.55 & 0.048 & 70 & 29(20)^{(c)} \\ 5 & 1.47 & 0.016 & 70 & 32(23)\end{array}$

(a) Sum of soil losses from plot during dry, wet, and very wet soil surface rain simulator runs, adjusted for losses from a standard USLE unit plot.

(b) Total soil loss from the vegetated plot divided by average total soll loss from the cultivated erosion plots.

(c) Numbers in parentheses represent percentages of cover where gravel and wheatgrass were both present in the field; i.e., for plot $4,29 \%$ of the 385 field locations had wheatgrass present, but $20 \%$ of the 385 field locations also had gravel present. 
determinations were performed at sampling depths in the topsoil $(15 \mathrm{~cm})$, in the crushed tuff $(30,46,76,91$, and $107 \mathrm{~cm})$, and in the undisturbed tuff beneath the simulated trench cap $(122,137$, and $152 \mathrm{~cm})$.

Over 2 years' worth of neutron moisture gauge data laverage values for three locations in plot) from erosion plot 6 , which received the smooth bare soil treatment (with no vegetative cover), are presented in Figure 1.32. In spite of the fact that approximately $110 \mathrm{~mm}$ of water was applied to each of these plots on June 22 and 23, 1982, no increase in soil water was detected at any depth over that observed before the simulated rainfall on June 21. Interestingly enough, large increases in soil moisture were found up to $122 \mathrm{~cm}$ below the surface of the trench cap as a resuit of meiting snow after December 14, 1982. As the spring and summer of 1983 passed, the soil water levels in the top $76 \mathrm{~cm}$ of the trench cap decreased due to evaporative losses and then again increased to greater than $30 \%$ water content, with the addition of precipitation to the trench cap in the late summer rainy season. The final soil water content at the bottom of the trench cap (91- to 107-cm depth) increased during this same pariod to $23-27 \%$, and the undisturbed tuff beneath the trench cap attained water content values of $12-16 \%$.

Tillage for seedbed preparation, weed control, or other purposes is the most common soil management process. For the erosion plots with the cultivated (tilled) treatment, the disking process resulted in an opening and loosening of the tilled layer and decreased the occurrence of the extensive cracks observed at the surface of the erosion plot (Figure 1.33). However, the final soil water content at the bottom of the simulated trench cap and beneath the cap was considerably less for the cultivated plot than for the bare soil plot; i.e., water content values ranging from 14 to $24 \%$ were observed at the bottom of the trench cap, and values ranging from only 8 to $10 \%$ were observed beneath the trench cap. Thus, the overall effect of tillage seemed to be that of enhancing desiccation of the SLB trench cap.

The field studies, involving partial gravel covers, all resulted in similar effects on the distribution of water in the simulated trench cap. The overall effect of the gravel and base course covers was to almost immediately enhance the water content in the upper layers of the trench cap relative to the bare soil treatment; however, lower water content values 

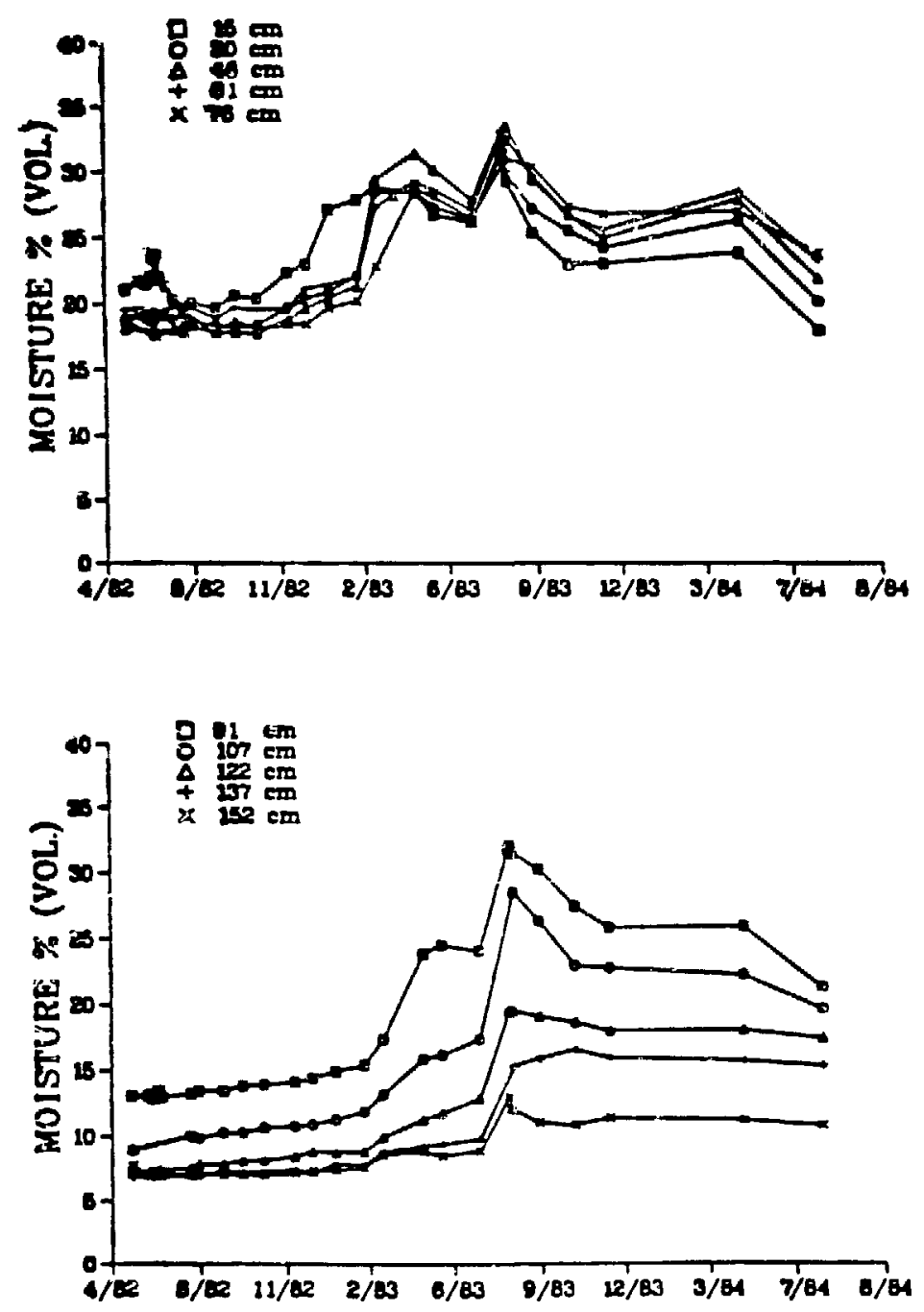

FIGURE 1.32. Subsurface Water Content Data from Plot 6 with Bare Soil Trea tment. 

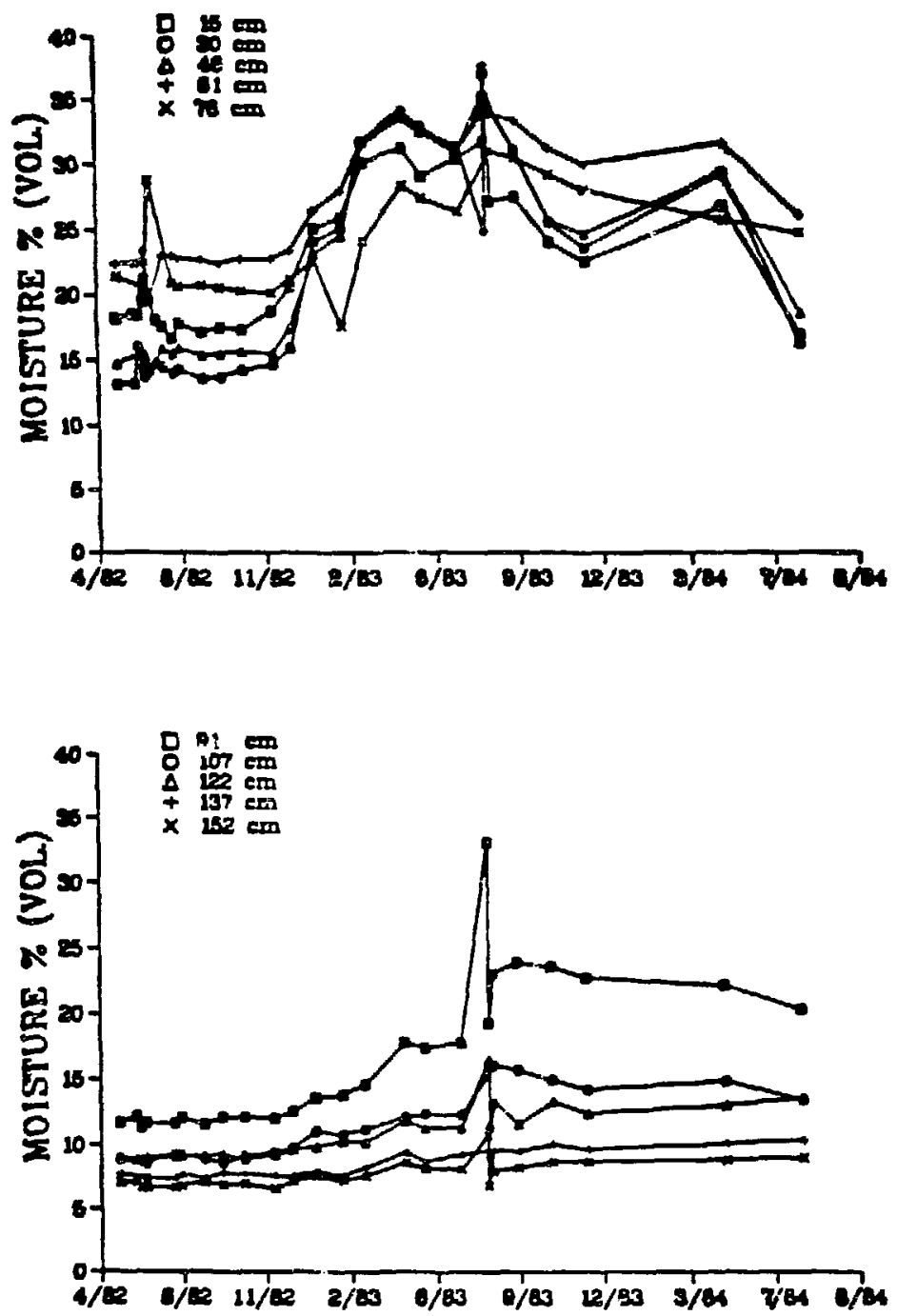

FIGURE 1.33. Subsurface Water Content Data from Plot 1 with Cultivated Treatment. 
were observed from 91 to $152 \mathrm{~cm}$ under the base course treatment than at similar depths in the erosion plots with the bare soil treatment.

\subsection{Moisture Cycling Effects on Chemical Transport. A process} about which little is known is the effect of capillary forces created by evaporation of water at the soil surface in drawing soil moisture and soluble chemicals to the surface of a low-level waste site. The importance of this process as a radionuclide transport mechanism was evaluated as functions of initial soil water status, simulated waste burial depths, and the presence or absence of plants. Stable isotopes of cesium, strontium, and cobalt., as well as tritiated water, were added to each experimental field unit (0.91-m diameter by 1.5-m-deep metal culverts) filled with crushed tuff. This field experinent was initiated on July 2, 1981, and horizontal soil cores were collected in each experimental unit to determine the vertical distribution of tracers when the experiment was terminated on October 15. 1982 .

The results of this experiment (Perkins 1984) indicate that for cesium and coba?t, no significant differences could be detected in the distribution of tracers during the experiment, with or without plants present, at either the 28- or 62-cm original tracer placement depths. For strontium, the peak concentration moved downward in the barren soils, whereas little migration was detected in the soils permeated by plant roots, probably because of less downward movement of the soil water.

The vertical distribution data for tritium exhibited considerably different trends. With the tritium tracer level originally emplaced at 28 $\mathrm{cm}$ in crushed tuff at $50 \%$ saturation, the vertical distribution of tritium is presented in Figure 1.34 for experimental units with and without plants present. In the absence of plants, the peak tritium concentration band migrated over $60 \mathrm{~cm}$, and $85 \%$ of the original tritium inventory was retained. With plants present, the peak tritium concentration band only migrated about $40 \mathrm{~cm}$, and $91 \%$ of the total tritium inventory was lost from the container by evapotranspiration processes. Similar results were obtained when the original tritium emplacement depth was $62 \mathrm{~cm}$ (Figure 1.35). 


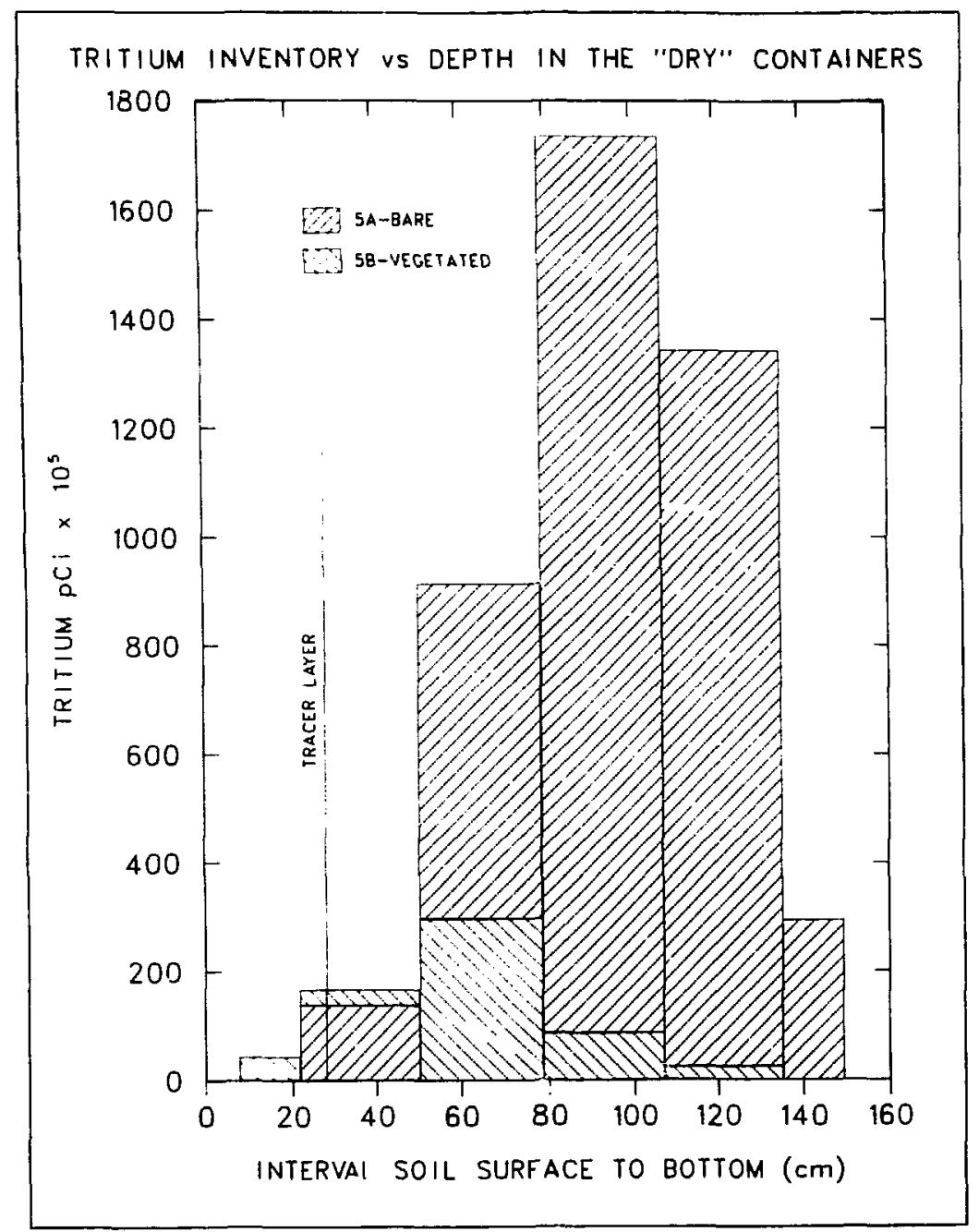

FIGURE 1.34. Tritium Inventory vs Depth for the Moisture Cycling Experiment (Experimental Units $5 A$ and $5 B$ ). 


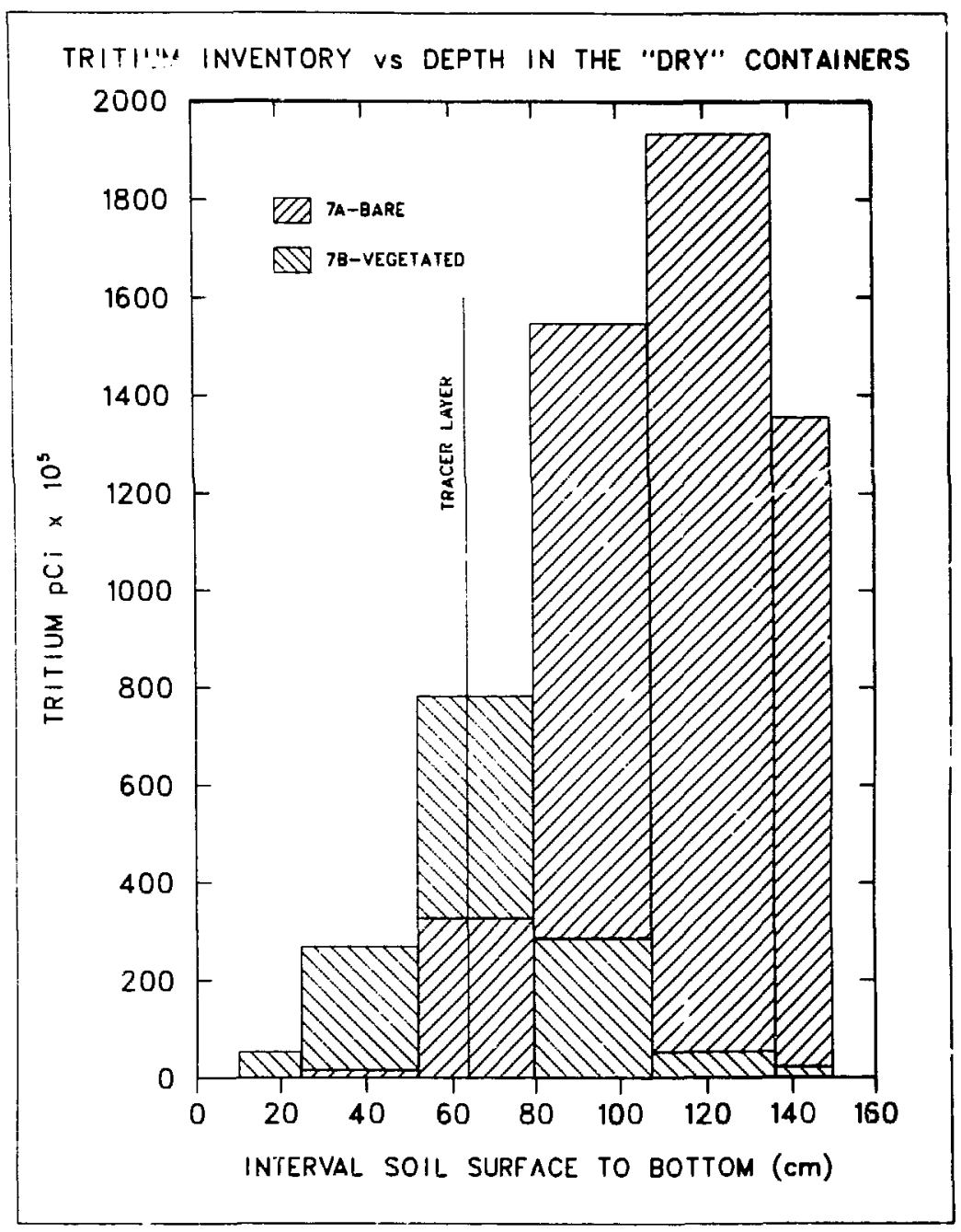

FIGURE 1.35. Tritium Inventory vs Depth for the Moisture Cycling Experiment (Experimental Units $7 \mathrm{~A}$ and $7 \mathrm{~B}$ ). 
These observations indicate that in burial sites containing tritium, if roots penetrate into the region containing tritium, tritium mobilization *ill increase and similar results will probably not be encountered with upward migration of cesium, cobalt, and strontium.

1.3.5.3.6 Subsidence Studies. Subsidence cavities measured on actual burial trenches vary widely in both size and shape, from broad. shallow depressions to narrow pipes that may extend to the waste. Burial site surveys indicate that about $85 \%$ of the measured cavities are less than 2.75 $\mathrm{m}$ in diameter and $95 \%$ are less than $4.25 \mathrm{~m}$ in diameter.

In field experiments, in order to stress the biobarrier, cavities of four sizes were created. There are two replicates of each and two control plots. The experiments are conducted in a trench $38 \mathrm{~m} 1$ ong, $15 \mathrm{~m}$ wide, and $3 \mathrm{~m}$ deep. In the bottom of each $53-\mathrm{m}^{2}$ experimental plot, a $0.9-\mathrm{m}$-diameter hole was augered to a depth necessary to equal the desired volume of the subsidence cavity $(1.4,3.4,6.4$, and $11.5 \mathrm{~m}$ deep). Over each of these drawholes, there was a $2.25-\mathrm{m}^{2}$ steel plate containing a hinged trap dcor fastened closed by explosive closures. One side of the drawholes was cut away flat to a depth of $1 \mathrm{~m}$ to allow the door to open fully. The eitire trench was backfilled to a depth of $2.2 \mathrm{~m}$ with crushed tuff, which was screened to remove particles larger than $5 \mathrm{~cm}$ to prevent clogging. The backfill was overlain by $0.9 \mathrm{~m}$ of cobble-gravel biobarrier material and soil. A layer of cesium-chloride tracer was placed at the backfill/barrier interface. Alfalfa was then planted uniformiy on the surface.

When the explosive closures were released, the trap doors fell downward, allowing the backfill to drain into the drawholes, causing subsidence at the surface of the field plot. Slow settlement of the entire trench surface should be observable throughout the duration of the experiment, resulting from continued stabilization of the backfill.

From this experiment it is obvious that the crushed tuff and/or the soil have some cohesiveness as was demonstrated in the laboratory (Abee le 1984). The lab results also show that, even for crushed tuff, a higher degree of consolidation or compression is at the origins of an increase in soil strength. (It is well known that densification causes soil stabilization.) The bottom of the 1andfil1, which is submitted to a pressure averaging $50 \mathrm{kPa}$, could consequeritly be fairly well stabilized 
when dry. A completely cohesionless porous medium (0ttawa sand, for example) would have undergone immediate subsidence into the 0.9 -m-diameter dratiholes when the trap doors were released. This was obviously not observed when the trap doors, overlain by crushed tuff, were opened.

flooding of the area immediately overlying the drawholes caused subsidence in two holes $1.4 \mathrm{~m}$ deep, two holes $3.4 \mathrm{~m}$ deep, two holes $6.4 \mathrm{~m}$ deep, and one hole $11.5 \mathrm{~m}$ deep. This is one hole more than was predicted possible due to supposed failure of opening of two trap doors.

The total volume of the subsided cavities seems to relate pretty well as 1:2.5:8.5 or roughly the relationship existing in the size of the respective drawholes (Table 1-15). The volume of the cores is extremely difficult to compute for the two sinaller ones but averages around 90-95\% of the drawhole volume for the other ones. These results are justifiable because pores created by rocks filling the drawholes will be at the origin of a lower bulk density in the drawhole and will correspond to a smaller conic volume at the surface.

TABLE 1-15. Relationship of Subsidence to Width (W) and Depth (k)

$\begin{array}{rlll}\frac{W(m)}{2} & \underline{k(m)} & \underline{W / k} & \underline{S / m} \\ 90 & 310 & 0.29 & 0.18 \\ 135 & 465 & 0.29 & 0.22 \\ 180 & 620 & 0.29 & 0.20 \\ 225 & 775 & 0.29 & 0.19 \\ 270 & 930 & 0.29 & 0.22\end{array}$




\section{REFERENCES}

Abeele, W. V., M. L. Wheeler and B. W. Burton. 1981. Geohydrology of Bandelier Tuff. LA-8962-MS, Los Alamos National Laboratory, Los Alamos New Mexico.

Abee le, W. V. 1984. Geotechnical Aspects of Hackroy Sandy Loam and Crushed Tuff. LA-9916-MS, Los Alamos National Laboratory, Los ATamos, New Mexico.

Abrahams, J. H., Jr., E. H. Baltz and W. D. Purtymun. 1962. Movement of Perched Ground Water in Alluvium Near Los Alamos, New Mexico. U.S. Geo7. Survey Prof. Paper 450-B.

Abrahams, J. H., Jr., J. E. Weir, Jr. and W. D. Purtymun. 1961. Distribution of Moisture in Soll and Near-Surface Tuff on the Pajarito Plateau, Los Alamos County, New Mexico. U.S. Geol. Survey Prof. Paper 424-D.

Bailey, R. A., R. L. Smith and C. S. Ross. 1969. Stratigraphic Nomenclature of Volcanic Rocks in the Jemez Mountains, New Mexico. U.S. GeoT. Survey BuTा. 1274-P.

Briggs, G. A. 1975. "Plume Rise Predictions," in Lectures on Air Poliution and Environmental Impact Analyses, Workshop Proceedings, Boston, Massacusetts. American Meteorological Society, Boston, Massachusetts.

Budding, A. J., and W. D. Purtymun. 1976. Seismicity of the Los Alamos Area Based on Geologic Data. LA-6278-MS, Los Alamos Scientific Laboratory, Los Alamos, New Mexico.

Cabot, E. C. 1938. "Fault Border of the Sangre de Cristo Mountains North of Santa Fe, New Mexico." J. Geol. \$6:1.

Church, H. H. 1969. Cloud Rise from High Explosive Detonations. SC-RR68-903, Sardia Laboratory, Albuquerque, New Mexico.

Coates, D. W. 1984. Natural Phenomena Hazards Modeling Project: Extreme Wind/Tornado Hazard Models for Department of Energy Sites. UCRL-53526, Lawrence Livermore National Laboratcry, Livermore, Caîfornia.

Cooper, J. B., H. D. Purtymun and E. C. John. 1966. Records of HaterSupply Wel1s, Guaje 6, Pajarito Mesa 1, and Pajarito Mesa 2, Los Alamos, New Mexico U.S. Geo1. Survey Admin. Paper.

Cushman, R. L. 1965. An Evaluation of the Aquifer and He11 Characteristics of the Municipal Well Fields in the Los Alamos and Guaje Canyons Near Los Alamos, New ilextco. U.S. Geol. Survey Water-Supply Paper 1oc?-0. 
Dames and Moore Earth Science. 1972. Report of Geologic, Hydrologic, and Seismic Investigations, Plutonium Processing Facilities, Los ATamos Scientific Laboratory. Los Alamos, New Mexico. Dames and Moore, Lcs Angeles, California.

Denny, C. S. 1940. "Santa Fe Formation in the Espanola Valley, New Mexico." Geol. Soc. Am. Bu11. 51:5.

Dreicer, M. 1981. Rainfall as a Mecharism for Soil Contamination of Plant Surfaces. MS Thesis, Colorado State University, Fort Collins, Colorado.

Environmental Surveillance Group. 1985. Environmental Survelllance at Los Alamos During 1984. LA-10421-ENV, Los ATamos National Laboratory, Los Alamos, New Mexico.

Environmental Surveillance Group. 1984. Environmental Suryeillance at Los Alamos During 1983. LA-10100-ENV, Los ATamos National Laboratory, Los Alamos, New Mexico.

Galuska, T., and J. C. Blick. 1971. "Stratigraphy of the Santa Fe Group, New Mexico." Bull. Am. Museum Nat. Hist. 144:Art 1.

Gilbert, T. L., et a1. 1983. Pathways Analysis and Radioactive Dose Estimates for Radioactive Residues at Formerly UtiTized MEDTAEC Sites. OR0-832, U.S. Department of Energy, Washington, DC.

Griggs, R. L., and J. D. Hem. 1954. Geology and Ground-Water Resources of the Los Alamos Area, Naw Mexico. U.S. Geol. Survey Water-Supply Paper 1753.

Hakonson, T. E., et al. 1982. Some Interactive Factors Affecting Trench Cover Integrity on Low-Level waste Sites. NUREG/CP-0028, U. S. Nuclear Regulatory Commission, Oak Ridge, Tennessee.

Hakonson, T. E. 1985 (in preparation). Evaluation of Geologic Materials to Limit Biological Intrus'. in into Low-Level Radioactive haste Disposal Sites. Los Alamos National Laboratory, Los Alamios, New Mexico.

Lane, L. J., and J. W. Nyhan. 1985 (in preparation). Water and Centaminant Movement: Migration Barriers. Los Alamos National Laboratory, Los Alamos, New Mexico.

Kelley, V. C. 1952. "Tectonics of the Rio Grande Depression of Central New Mexico." New Mexico Geol. Soc. Guidebook. 3rd Field Conf.

Kelley, V. C. 1954. Tectonic Map of a Part of the Upper Rio Grande Area, New Mexico. U.S. Geol. Survey oft Inv. Map OM 157. 
Kelley, T. E. 1974. "Reconnaissance Investigations of Ground Water in the Rio Grande Drainage Basin, with Special Emphasis on Saline Ground Water Resources." U.S. Geol. Survey Atlas HA-510.

Lansford, R. R. 1973. An Analytical Interdisciplinary Evaluation of the Utilization of the Water Resources of the Rio Grande in New Mexico: Upper Rio Grande Region. Report No. 021, New Mexico Water Resources Research Institute, Las Cruces, New Mexico.

Miller, J. F., R. H. Fredrick, and R. J. Tracy. 1973. NOAA Atlas-2, Precipitation-Frequency Atlas of the Western United States, Volume IV--New Mexico. J.S. Department of Commerce, NOAA, National Weather Service, Silver Spring, Maryland.

Nyhan, J. H., et al. 1983a. Environmental Migration of Long-Lived Radionuclides Beneath a Former Los Alamos Liquid Waste Disposal $5 i$ te After 33 Years. LA-UR-83-1199, Los Alamos National Laboratory, Los Alamos, New Mexico.

Nyhan, J. H., et al. 1983b. "Field Studies of Erosion Control Technologies for Arid Shallow Land Burial Sites at Los A.lamos." In Proceedings of the Fifth Annual Participants Information Meeting, Department of Energy Low-Level Haste Management Program. CONF-8308106, Pp. 193-205, EG\&G Idaho, Inc., Idaho Falls, Idaho.

Nyhan, J. H., et a1. 1984. "Erosion of Earth Covers Used in Shallow Land Burial at Los Alamos, New Mexico." Journal of Environmental Quality 13:361-366.

Nyhan, L. W., L. W. Hacker, T. E. Calhoun and D. L. Young. 1978. Soil Survey of Los Alamos County, New Mexico. LA-6779-MS, Los Alamos Scientific Laboratory, Los Alamos, New Mexico.

Perkins, B. 1984. Geotechnical Aspects of Hackroy Sandy Loam and Crushed Tuff. LA-9916-MS, Los ATamos National Laboratory, Los Alamos, New Mexico.

Polzer, H. L., E. H. Essington, E. J. Cokal and D. M. Nelson. 1984. "Geochemical Mechanism of Contaminant Transport." In Environmental Suryeillance at Los Sîamos àt Los Alamos During 1983. LA-10100-ENV, Los ATamos National Laboratory, Los Alamos, New Mexico.

Purtymun, W. D., and F. C. Koopman. 1965. Physical Characteristics of the Tshirege Member of the Bandelier Tuff with Reference to Use as Building and Ornamental Stone. U.S. Geol. Survey Open-File Report.

Purtymun, H. D. 1966. Geology and Hydrology of White Rock Canyon from Otowi to the Confluence of Frijoles Canyon, Los ATamos and Santa Fe Counties, New Mexico. U.S. GeoT. Survey Admin. 
Purtymun, W. D. 1967. Record of Water-Supply We11 PM-3, Los Alamos, New Mexico. U.S. Geol. Survey Open-file Report.

Purtymun, W. D., and J. B. Cooper. 1969. Development of Ground-Water Supplies on the Pajarito Plateau, Los Alamos County, New Mexico. U.S. Geol. Survey Prof. Paper 650-B.

Purtymun, W. D., and W. R. Kennedy. 1971. Geology and Hydrology of Mesita del Buey. LA-4660, Los Alamos Scientific Laboratory, Los ATamos, New Mexico.

Purtymun, W. D. 1973. Underground Movement of Tritium from Solid-Waste Storage Shafts. LA-5286-MS, Los Alamos Scientific Laboratory, Los ATamos, New Mexico.

Purtymun, W. D. 1974. Dispersion and Movement of Tritium in a Shallow Aquifer in Mortandid Canyon at the Los Alamos Scientific Laboratory. LA-5716-MS, Los ATamos Scientific Laboratory, Los Alamos, New Mexico.

Purtymun, W. D., and S. Johansen. 1974. "General Geohydrology of the Pajari to Plateau, New Mexico. New Mexico Geol. Soc. Guidebook, 25th Fieli Conf.

Purtymun, W. D., M. L. Wheeler and M. A. Rogers. 1978. Geologic Description of Cores from Holes $P 3-M H-1$ through P3-MH-5, Area G, Technical Area 54. LA-7308-MS, Los Alamos Scientific Laboratory, Los ATamos, New Mexico.

Sanford, A. R. 1976. Seismicity of the Los Alamos Region Based on Seismological Data. [A-6416-MS, Los Alamos Scientiffic Laboratory, Los Alamos, New Mexico.

Schiager, K. J., and K. E. Apt, compilers. 1974. Environmental Surveillance at Los Alamos During 1973. LA-5586, Los A1amos Scientific Laboratory, Los Alamos, New Mexico.

Smith, R. L., R. A. Bailey and C. S. Ross. 1970. "Geologic Map of the Jemez Mountains, New Mexico." U.S. Geol. Survey Misc. Geol. Inv. Map I 571.

Spiegel, Z., and B. Baldwin. 1963. Geology and Water Resources of the Santa Fe Area, New Mexico. U.S. GeoT. Survey Water-Supply Paper 1525.

Stephen R. Flanc \& Associates. 1976. Upper Rio Grande Basin Plan. New Mexico Water Quality Control Commission, Pp. V-1 to V-22.

Theis, C. V., and C. S. Conover. 1962. Pumping Test in the Los Alamos Canyon Well Field Near Los Alamos, New Mexico. D.S. Geot. Survey Water-Supply Paper 1619-1. 
Tierney, G. D., and T. S. Foxx. 1982. Floristic Composition and Plant Succession on Near-Surface Radioactive Waste Disposal FaciTities in the Los Alamos National Laboratory. LA-9219-MS, Los Alamos National Laboratory, Los Alamos, New Mexico.

Travis, B. J. 1984. TRACR3D: A Model of Flow and Transport in Porous/Fractured Media. LA-9667-MS, Los ATamos National Laboratory, Los Alamos, New Mexico.

U.S. DOE. 1983. Radiological Guidelines for Application to DOE's Formerly Utilized Sites Remedial Action Program. ORO-831, Department of Energy, Washington, DC.

Walker, L. J., et a1. 1981. Alternative Transuranic Waste Management Strategies at Los Alamos Nationa! Laboratory. LA-8982-MS, Los Alamos National Laboratory, Los Alamos, New Mexico.

'Veir, J. E., Jr., and W. D. Purtymun. 1962. Geology and Hydrology of Technical Area 49, Frijoles Mesa, Los Alamos County, New Mexico. U.S. Geo1. Survey Admin. Report.

Weir, J. E., Jr., et al. 1963. The Hydrology and the Chemical and Radiochemical Quality of Surface and Ground Water at Los ATamos, New Mexico, 1949-1955. U.S. Geo7. Survey Admin. Report.

Wheeler, M. L., and J. L. Warren. 1975. "Tritium Containment After Burial of Contaminated Solid Waste." Proceedings of 23rd Conference on Rewater System Technology, American NucTear Society, San Francisco, Calffornia.

Wheeler, M. L., W. J. Smith and A. F. Gallegos. 1977. Preliminary Evaluation of the Potential for Plutonium Release from Burial Grounds at Los Alamos Scientific Laboratory. LA-6694, Los Alamos Scientific Laboratory, Los Alamos, New Mexico.

Wischmeier, W. H., and D. D. Smith. 1978. Predicting Rainfall Erosion Losses--A Guide to Conversation Planning. USDA Handbook 537. Washington, DC. 


\subsection{SOURCE TERM DESCRIPTION}

\subsection{SOLID WASTES}

From the earliest days of Laboratory operations until mid-1971, common practice was to dispose of radioactive wastes by burial in designated locations. Transuranic wastes had not been defined as a separate category and did not require any special handling or treatment. The Atomic Energy Commission then defined TRU wastes and required that they be segregated and retrievably stored for a 20 -year period. Thus, many of the burial facilities used at Los Alamos before this ruling contain some TRU wastes mixed with low level wastes (LLW).

The radioactivity in the pre-1971 wastes included TRU materials, uranium, Mixed Fission Products (MFP), Mixed Activation Products (MAP), and tritium. Typically, the wastes with the higher levels of radioactivity were associated with beta and gamma radiation emitted from MFP and MAP activities.

Typical wastes include tools, instruments, equipment, building materials (from the decontamination and decommissioning of older faciitities), sludge, cement, and generai refuse (such as paper, plastics, rubber, and glassware) that are lightly contaminated or that come from areas where TRU is in use.

Experience, extensive research, continuous environmental surveillance, and drilling around and under buried waste have shown that pits and shafts dug into the tuff on mesa tops are the most effective method of waste disposal in: this area (U.S. DOE 1979a; Purtymun, Peters and Stoker 1980; Purtymun, Rogers and Wheeler 1980; Purtymun, Garde and Peters 1978; and Warren 1980).

Before 1971, all solid radioactive waste was buried in common pits, trenches, and shafts. Since the late 1950s, waste containing higher levels of activity has usually been placed in the shafts. Pits typically are approximately $8 \cdot 014 \mathrm{~m}$ deep by 8 to $30 \mathrm{~m}$ wide by 120 to $180 \mathrm{~m}$ long ( 25 to $45 \mathrm{ft}$ deep by 25 to $100 \mathrm{ft}$ wide by 400 to $600 \mathrm{ft}$ long); however, these dimensions vary greatly. The wastes are placed in layers in the pits, and the curresi practice is to cover each day's addition with clean fill. When the iop layer of wastes come to within about $1 \mathrm{~m}(3 \mathrm{ft})$ of the surface of 
the adjacent undisturbed terrain (measured at the "spill point" of the pit), the pit is closed by covering to the ground surface with a minimum of $1 \mathrm{~m}(3 \mathrm{ft}$ ) of clean fill material (tuff). Approximately $0.1 \mathrm{~m}$ (4 in.) of topsoil then is added, and the surface is revegetated with native grasses. When subsidence occurs, additional fill is adde, to level the surface with the surrounding terrain.

Shafts are drilled vertically to depths of 8 to $20 \mathrm{~m}(25$ to $65 \mathrm{ft})$ and from about 0.6 to $2.5 \mathrm{~m}(2$ to $R \mathrm{ft}$ ) in diameter. Although a few shafts have been lined with concrete or metal, most are not. Wastes are periodically placed in the shafts. Additional fill (tuff) is occasionally needed above the wastes for sinielding to decrease the radiation dose rates. In some extreme cases, cement has been added. When the wastes fill the shaft to no closer than about $1 \mathrm{~m}(3 \mathrm{ft})$ of the surface, a thin layer of tuff is added and then cement poured and mounded to seal the shaft.

\section{1 .1 Description of Solid Waste Disposal Sites}

The buried TRU wastes and LLW discussed in Section 2.1 are located in six major and eight small inactive waste disposal areas (see Figure 1.16). A b:-ief description of the major areas and their estimated volumes are given below and summarized in Table 2-1.

The total volume of the pits, trenches, shafts, and storage from the major areas is estimated from existing records projected to the year 1990 [tota] $\left.\sim 330,000 \mathrm{~m}^{3}\left(\sim 12,000,000 \mathrm{ft}^{3}\right)\right]$. Significant amounts of $L L W$ and backfill or cover material have been inixed with the buried TRU wastes. This backfill material may have been contaminated by mixing. The estimated volume includes the total volume of the burial pits, trenches, and shafts, minus the top $1 \mathrm{~m}(3 \mathrm{ft})$ of final cover above the wastes. The following descriptions of the 14 disposal areas are summarized frCm US DOE 1979a and Rogers 1977.

- Area A (operated with four burial pits from 1945-1946). A fifth pit was opened in April 1969 and used until mid-1978 for building decontamination and decommissioning (D\&D) wastes. Area $A$ covers $5000 \mathrm{~m}^{2}\left(1.25\right.$ acres of $\left.53,800 \mathrm{ft}^{2}\right)$ with the actual waste pits 
TABLE 2-1. Description of Solid Waste Disposal Sites

\begin{tabular}{|c|c|c|c|c|c|c|c|}
\hline $\begin{array}{l}\text { O1sposal } \\
\text { Area } \\
\end{array}$ & $\begin{array}{l}\text { Disposal } \\
\text { System }\end{array}$ & $\begin{array}{l}\text { O1 sposal } \\
\text { Method }\end{array}$ & TRU Waste & Naste Form & $\begin{array}{c}\text { Waste } \\
\text { Volume }(a) \\
{\left[m^{3}\left(f t^{3}\right)\right]} \\
\end{array}$ & $\begin{array}{r}\text { St }-c e \\
\operatorname{arc}(b) \\
{\left[m^{3}\left(f^{2}\right)\right]} \\
\end{array}$ & Remarks \\
\hline$A$ & Pits (5) & Buried & $\begin{array}{l}\text { Possibiy } 5 \text { mall } \\
\text { quantity }\end{array}$ & $\begin{array}{l}\text { Combustible and } \\
\text { noncombustible }\end{array}$ & $\begin{array}{c}14,000 \\
(500,000)\end{array}$ & $\begin{array}{c}2600 \\
(28,000)\end{array}$ & $\begin{array}{l}\text { Contains hazardous chemical } \\
\text { wastes in the four original } \\
\text { pits. }\end{array}$ \\
\hline 8 & Pits & Buried & $\begin{array}{l}\text { Probably small } \\
\text { quantity }\end{array}$ & $\begin{array}{l}\text { Combustible and } \\
\text { noncombustible }\end{array}$ & $\begin{array}{r}(21,000) \\
(750,000)\end{array}$ & $\begin{array}{c}4700 \\
(50,000)\end{array}$ & $\begin{array}{l}\text { Number and location of pits } \\
\text { within area unknown. Contains } \\
\text { hazardous chemical wastes. } \\
\text { Estimated to contain } 100 \mathrm{~g} \\
\text { of plutonium. }\end{array}$ \\
\hline C & Pits $(6)$ & Buried & Yes (6) & $\begin{array}{l}\text { Combustible and } \\
\text { noncombustible }\end{array}$ & $\begin{array}{c}103,000 \\
(3,650,000)\end{array}$ & & $\begin{array}{l}\text { Cuntains hazardous chemical } \\
\text { wastes. }\end{array}$ \\
\hline $\mathrm{C}$ & $\begin{array}{l}\text { Unlined } \\
\text { shafts }(97)\end{array}$ & Buried & $\begin{array}{l}\text { Yes }(42) \\
\text { No }(55)\end{array}$ & $\begin{array}{l}\text { Combustible and } \\
\text { noncombustible }\end{array}$ & $\begin{array}{c}140 \\
(5000)\end{array}$ & $\begin{array}{c}23,000 \\
(250,000)\end{array}$ & \\
\hline $\mathrm{C}$ & $\begin{array}{l}\text { Steel/cement } \\
\text { lined shafts }(10)\end{array}$ & Burted & $\begin{array}{l}\text { Yes (6) } \\
\text { No (4) }\end{array}$ & $\begin{array}{l}\text { Conbustible and } \\
\text { noncombustible }\end{array}$ & $\begin{array}{c}5 \\
(175)\end{array}$ & & \\
\hline $\mathbf{G}$ & $\begin{array}{l}\text { Pit } 8 \text { conteins abo } \\
\text { non } \cdot \text { TRU waste sluds }\end{array}$ & $\begin{array}{l}\text { ut } 10 \text { drums } \\
\text { ge. }\end{array}$ & containing TRU wa & $\begin{array}{l}\text { Combustible } \\
\text { noncumbustible, } \\
\text { sludge, concrete }\end{array}$ & $\begin{array}{c}170,000 \\
(6,000,000)\end{array}$ & $\begin{array}{c}33,000 \\
(360,000)\end{array}$ & $\begin{array}{l}\text { Pits } 1-6 . \text { Pits used for } \\
\text { waste disposal before } \\
\text { directive requiring segrega- } \\
\text { tion of TRU waste. About } \\
600-9239 \text { in } 20 \text { drums in } \\
\text { Pft } 1 \text {. Drums with sludge } \\
\text { and concrete in } P 1+2 \text { con- } \\
\text { tain TRU }>10 \mathrm{nC} / \mathrm{g} \text {. }\end{array}$ \\
\hline G & Pit 9 & Stored & res & $\begin{array}{l}\text { Combustible, } \\
\text { nonconoustible, } \\
\text { and siudge }\end{array}$ & $\begin{array}{c}1300 \\
(47,000)\end{array}$ & $\begin{array}{c}1000 \\
\vdots 12,000)\end{array}$ & \\
\hline G & Trenches & Stored & Yes & $\begin{array}{l}\text { Combustible and } \\
\text { noncombustible }\end{array}$ & $\begin{array}{c}240 \\
(8400)\end{array}$ & $\begin{array}{c}3300 \\
(35,000)\end{array}$ & $\begin{array}{l}\text { Volume includes casks. Actual } \\
\text { waste is about } 64 \mathrm{~m}^{3} \text { (2250 } \\
\left.\text { ft }{ }^{3}\right) \text {. Haste is } 238 \mathrm{Pu}-\text { and } \\
233 \mathrm{u} \text {-contaminated in } 114-\ell \\
\text { (30mga?) drums, } 2 \text { drums per } \\
\text { concrete cask. }\end{array}$ \\
\hline G & Shafts $(66)$ & Buried & Yes & $\begin{array}{l}\text { Combustible, } \\
\text { noncombustible, } \\
\text { liquids, and } \\
\text { aspha?ted trititum }\end{array}$ & $\begin{array}{c}430 \\
(15,000)\end{array}$ & $\begin{array}{c}580 \\
(6200)\end{array}$ & $\begin{array}{l}\text { TRU waste with considerable } \\
B-Y \text { activity. }\end{array}$ \\
\hline
\end{tabular}


TABLE 2-1 (cont)

\begin{tabular}{|c|c|c|c|c|c|c|c|}
\hline $\begin{array}{l}\text { Disposal } \\
\text { Area } \\
\end{array}$ & $\begin{array}{l}\text { Disposal } \\
\text { System }\end{array}$ & $\begin{array}{l}\text { Disposal } \\
\text { Method }\end{array}$ & TRU Waste & Waste Form & $\begin{array}{r}\text { Haste } \\
\text { Volume }(a) \\
{\left[\mathrm{m}^{3}\left(\mathrm{ft}^{3}\right)\right]} \\
\end{array}$ & $\begin{array}{c}\text { Surface } \\
\text { Area }(b) \\
{\left[\mathrm{m}^{3}\left(\mathrm{ft}^{2}\right)\right]} \\
\end{array}$ & Remarks \\
\hline G & Shafts & Stored & Yes & $\begin{array}{l}\text { Combustible and } \\
\text { noncombustible }\end{array}$ & $\begin{array}{c}5 \\
(175)\end{array}$ & $\mathrm{N}+1$ & $\begin{array}{l}\text { Waste is from hot cells. Yol- } \\
\text { ume includes sealed casks. }\end{array}$ \\
\hline $\mathbf{T}$ & $\begin{array}{l}\text { Absorption } \\
\text { beds }(4)\end{array}$ & Buried & Yes & Contaminated soll & $\begin{array}{c}2700 \\
(96,000)\end{array}$ & $\begin{array}{c}890 \\
(9600)\end{array}$ & About $10 \mathrm{Ci}$ of $239 \mathrm{Pu}$. \\
\hline $\mathrm{T}$ & $\begin{array}{l}\text { Unlined } \\
\text { shafis }(62)\end{array}$ & Buried & $\begin{array}{l}\text { Yes }(56) \\
\text { Ho }(15)\end{array}$ & Concrete monoliths & $\begin{array}{c}3800 \\
(135,000)\end{array}$ & $\begin{array}{c}840 \\
(9000)\end{array}$ & $\begin{array}{l}1.8-\text { and } 2.4-m(6-\text { and } 8-f t)- \\
\text { diam shafts up to } 20 \mathrm{~m}(65 \mathrm{ft}) \text {. }\end{array}$ \\
\hline $\mathbf{T}$ & CMP shafts (175) & Stored & Yes & Concrete monoliths & $\begin{array}{c}480 \\
(17,000)\end{array}$ & $\begin{array}{c}140 \\
(1500)\end{array}$ & $\begin{array}{l}0.8-\mathrm{m}(2-1 / 2-\mathrm{ft}) \text { diam } \times 6.1 \mathrm{~m} \\
(20 \mathrm{ft}) \text { long. }\end{array}$ \\
\hline$v$ & $\begin{array}{l}\text { Absorption } \\
\text { beds (3) }\end{array}$ & Buried & No & Contaminated soll & $\begin{array}{c}4300 \\
(150,000)\end{array}$ & $\begin{array}{c}1400 \\
(15,000)\end{array}$ & $\begin{array}{l}\text { Liquid waste from DP-Site } \\
\text { laundry. }\end{array}$ \\
\hline
\end{tabular}

(a) Estimated volume of Intermixed waste and soll in pits [pit volume less top $0.9 \mathrm{~m}(3 \mathrm{ft})$ ], ds of Dec. 31, 1979.

(b) Surface area of wastes only, not total area of the waste disposal site. 
occupying $\sim 2600 \mathrm{~m}^{2}\left(28,000 \mathrm{ft}^{2}\right)$ of surface area. The total volume of the waste pits in Area $A$ is $\sim 14,000 \mathrm{~m}^{3}\left(500,000 \mathrm{ft}^{3}\right)$. The first four pits in Area $A$ were also used for the disposal of some chemical wastes.

- Area B (used 19:6-1948). Area B encompasses 24,000 $\mathrm{m}^{2}$ (6.0 acres of $\left.258,250 \mathrm{ft}^{2}\right)$. Buried waste pits occupy $\sim 4700 \mathrm{~m}^{2}\left(50,000 \mathrm{ft}^{2}\right)$ of surface area with an estimated total volume of $\sim 21,000 \mathrm{~m}^{3}(750,000$ $\mathrm{ft}^{3}$ ). The wastes contain small amounts of TRU and some hazardous chemicals and gas cylinders. A search of Laboratory records show an estimated $100 \mathrm{~g}$ of plutonium may be contained in these buried wastes.

- Area C (pits opened in 1948 with 6 burial pits used through 1964 and $\sim 100$ shafts used through 1969). The surface area is $\sim 48,000 \mathrm{~m}^{2}(11.8$ acres or $516,500 \mathrm{ft}^{2}$ ) with a pit surface area occupying $21,000 \mathrm{~m}^{2}$ $\left(225,000 \mathrm{ft}^{2}\right)$ and an estimated totay waste pit volume of $103,000 \mathrm{~m}^{3}$ $\left(3,650,000 \mathrm{ft}^{3}\right)$.

- Area C Shafts (wastes containing larger quantities of radioactive material placed in vertical shafts beginning in 1958). Laboratory records show that 107 shafts were excavated; a few of these were lined with CMP or cement, but most were not. The total volume of TRU wastes in these shafts is estimated to be $\sim 140 \mathrm{~m}^{3}$ (5000 $\left.\mathrm{ft}^{3}\right)$. An estimated 42 of the unlined shafts and 6 of the lined shafts may contain TRU wastes, whereas 55 of the unlined shafts and 4 of the lined shafts probably do not contain TRU wastes.

- Area $E$ was used between 1949 and the mid-1960s for burtal of contaminated solid wastes. Unknown amounts of material contaminated with $238 \mathrm{U}, 210 \mathrm{Po}$, and Be were disposed of. Essentially all of the $210 \mathrm{Po}$ has decayed.

- Area $F$ is located on Two-Mile Mesa and was used, from 1946 through perhaps the early fifties, for local disposal of wastes before the organization of a Laboratory-wide disposâl section. Wastes were 
placed in shallow pits or trenches, but information on the types and quantities of radionuclides disposed of is not available. Some $90 \mathrm{Sr}$ and about $30 \mathrm{mci}$ of $137 \mathrm{Cs}$, as well as high explosives wastes, may be present.

- Area G (the primary solid waste disposal and storage area at Los Alamos, in use since 1957, with 26 pits currently used or in use). The larger pits are typically $30 \mathrm{~m}(100 \mathrm{ft})$ wide by $180 \mathrm{~m}(600 \mathrm{ft})$ long by 8 to $14 \mathrm{~m}$ ( 25 to $45 \mathrm{ft}$ ) deep with smaller pits of varying dimensions. Additionally, several shallow trenches are used for the retrievable storage of TRU wastes in concrete casks. Pits 1 through 6 probably contain some TRU waste disposed of before 1971 and, therefore, mixed with LLW. Pit 1 is known to contain $\sim 600 \mathrm{~g}$ of plutonium mixed with sand in about $30114-\ell$ (30-gal) drums. Pit 2 contains drums of sludge with $>10 \mathrm{nci} / \mathrm{g}$ of TRU waste. This sludge is mixed in concrete. These first six pits occupy a surface area of $\sim 33,000 \mathrm{~m}^{2}\left(360,000 \mathrm{ft}^{2}\right)$, with an estimated total pit volume of $\sim 170,000 \mathrm{~m}^{3}\left(6,000,000 \mathrm{ft}^{3}\right)$. In addition, Pit 8 contains several drums of TRU waste. The waste volume in Pit 9 (used for storage from 1974 to 1979$)$ is $\sim 1300 \mathrm{~m}^{3}\left(47,000 \mathrm{ft}^{3}\right)$, whereas the storage trenches contain $\sim 240 \mathrm{~m}^{\mathrm{s}}\left(8400 \mathrm{ft}^{3}\right)$. All the other pits and trellches contain only LLW.

- Area G Shafts ( 120 vertical shafts are now located in Area G, with an estimated surface area of $\sim 580 \mathrm{~m}^{2}\left(6000 \mathrm{ft}^{2}\right)$ and total volume of $\sim 430$ $\mathrm{m}^{3}$ or $15,000 \mathrm{ft}^{3}$ ). Some of the shafts used before 1971 contain mixed TRU, MFP, MAP, and other LLW. Generally, wastes with higher levels of radioactivity have been disposed of in shafts rather than in pits.

Area $G$ burial pits and shafts contain tritium, mixed fission products, uranium, activation pruducts, $239 \mathrm{Pu}, 241 \mathrm{Am}$, arid small amounts of other nuclides (such as 238Pu, 237Np, 230Th, 232Th, and curium isotopes).

- Area $H$ contains shafts used for the disposal of uncontaminated classified material. However, some radioactive material was inadvertently placed in this area because of some trace-level tritium contamination 
detected in subsurface samples taken near one of the shafts. Only limited records are available to determine the nature or amount of what was buried.

- Area $K$ is located near HP-Site and was operated for the local disposal of wastes generated at that site. A shallow pit in the area was used for disposai of tritium-contaminated solutions between 1950 and 1959. Septic tanks in the area have received liquid wastes contaminated with $235 \mathrm{U}$ and $238 \mathrm{U}$. One additional septic tank received two emergency releases of plutonium-contaminated liquid in 1961. No records are available to dccument the curie content.

- Area T. Four absorption beds were used from 1945 to 1952 for the disposal of untreated liquid wastes from plutonium processing, which contained low levels of plutonium and americium. The total surface area of the site is $-1900 \mathrm{~m}^{2}\left(20,000 \mathrm{ft}^{2}\right)$. The absorption beds are trenches $\sim 35 \mathrm{~m}$ long by $1.2 \mathrm{~m}$ deep by $6 \mathrm{~m}$ wide ( 115 by 4 by $20 \mathrm{ft}$ ), excavated into the tuff. The beds were backfilled with coarse material, grading from $0.2-m(8-i n$.$) boulders in the bottom, through$ gravel, to fine sand at the surface. The total volume of the four beds is $2700 \mathrm{~m}^{3}\left(96,000 \mathrm{ft}^{3}\right)$.

A treatment plant was installed in 1952 for removai of plutonium and other radionuclides from liquid wastes. Residues from this treatment plant were mixed with cement and buried in Areas $C$ and $G$. A new treatment plant was built in 1967. Since mid-1968 until 1978, treated waste residues were mixed with cement in a pug mill and pumped down shafts augered between the two beds to the south side and the two beds to the north side. About 62 of these shafts were used for the disposal of mixed cement and neutralized americium strip, alkaline fluoride, and plant sludge. The shaft dimensions are typically 1.2 to $2.4 \mathrm{~m}(4$ to $8 \mathrm{ft})$ in diameter and up to $24 \mathrm{~m}(80 \mathrm{ft})$ deep. These dimensions vary depending upon corditions found when they were augered. The volume of these 62 shafts is $23800 \mathrm{~m}^{3}\left(135,000 \mathrm{ft}^{3}\right)$. About 56 of these shafts contain TRU wastes, but 6 do not. 
- Area U contains two absorption beds similar to those in Area $r$. The beds were used for subsurface disposal of contaminated liquid wastes between 1945 and 1968 . The primary radionuclide present in these wastes was 210 Po. No records were kept of the amount discharged; however, the short half-life of the material would have produced a decay of the material to innocuous levels by 1972. During 1953, $\sim 2.5 \mathrm{Ci}$ of $227 \mathrm{Ac}$ were discharged to the pits.

- Area V (used from 1945 to 1961 with three absorption beds receiving waste water from a laundry). These absorption beds were also similar to those described in Area T. The estimated surface area is $1400 \mathrm{~m}^{2}$ $\left(15,000 \mathrm{ft}^{2}\right)$ with an estimated volume of contaminated material of $4300 \mathrm{~m}^{3}\left(150,000 \mathrm{ft}^{3}\right)$. Area $V$ contained $\sim 3 \mathrm{Ci}, 90 \mathrm{Sr}, 140 \mathrm{Ba}, 140 \mathrm{La}$, and also $0.1 \mathrm{Ci}$ of plutonium at concentrations that are below 100$\mathrm{nCi} / \mathrm{g}$ TRU waste limits.

- Area $W$ is used for the subsurface storage of two coolant tanks associated with the LAMPRE reactor dismantled in 1963. Two stainless steel tanks, each containing 110-115 \& (30 gal) of irradiated metallic sodium, are encased in carbon steel sleeves and located in separate vertical shafts about $35 \mathrm{~m}(115 \mathrm{ft})$ deep. The sodium is contaminated with $137 \mathrm{Cs}, 22 \mathrm{Na}$, and possibly $239 \mathrm{Pu}$. The total activity present in the tanks is not known.

- Area $X$, in close proximity to Area $H$, is being used for the subsurface storage of the LAMPRE reactor vesse?. The vessel was buried in 1964, containing only a residual amount of $235 \mathrm{U}$. 0ther activation products are also expected to be present. The thick stainless steel reactor walls provide containment adequate for storage in the dry tuff.

- Area $Y$ has been used since 1966 for disposal of waste from dynamic testing operations. The material consists principally of highexplosive contaminated wastes, although slight amounts of depleted uranium may be present. 


\subsubsection{Source Terms for Solid Waste Disposal Sites}

Hansen and Rodgers (1983) have recently assessed the radioactive solid wastes at Los Alamos and derived release source terms important for the ground water leaching pathway. The diverse mixture of waste forms currently disposed of and stored at Los Alamos have been divided roughly into two categories: ordinary trash or cardboard boxes of waste, without waste form modification, and solidified wastes such as cemented sludges in drums or retrievable wastes.

The calculation of source term strength, $J_{0}(x, y, t)$, for each of these categories was analyzed separately and then combined in a total alpha waste source term approximating the codisposal of all forms of alpha waste. For clarity, the several factors in the equations defining the source term strengths are described separately for conditions at Los Alamos starting with solidified wastes.

\subsubsection{Snurce Terms for Solidified Wuste}

The leaching to ground water depends critically on solidified waste geometry. But as the summary information in Table 2-2 indicates, a variety of containers such as drums and metal pipe shafts are utilized to contain cemented wastes.

Each of these waste forms would be expected to exhibit different leach release rates due to differences in surface to volume ratio. But as

TABLE 2-2. Solidified Alpha Wastes at Los Alamos

\begin{tabular}{|c|c|c|c|}
\hline Type & Number of Units & $\begin{array}{l}\text { Volume/Unit } \\
\quad\left(\mathrm{m}^{3}\right) \\
\end{array}$ & Major Radionuclide \\
\hline Drums & 12,000 & 0.210 & Defense plutonium \\
\hline Shafts & 180 & 2.8 & $241 \mathrm{Am}$ \\
\hline Shafts & 100 & 1.8 & Defense plutonium \\
\hline Drums & 480 & 0.85 & Heat source plutonium \\
\hline
\end{tabular}


Nielson, Colombo and Bradley (1981) pointed out, the measured low incremental leach rate of plutonium from bench-scale concrete forms would appear to imply that small cumulative fractions $\left(1.9 \times 10^{-6}\right.$ to $\left.1.9 \times 10^{-5}\right)$ of activity released will be from full-scale waste forms $(210 \ell)$, eyen over times as long as 105 years. However, these values depend critically on the stability of waste form and may be many orders of magnitude larger if the solid form cracks and crumbles. As a result, for long-lived alpha-emitting radionuclides, waste form stability will probably be the primary determinant of activity release over the potentially large time that must be considered for disposal. This, in turn, implies that there will likely be little loss if all the wastes are treated as having a standard $210-\ell$ drum form, because in the long run, all the wastes will probably have surfaceto-voiume ratios considerably larger than this.

Hansen and Rodgers (1983) assumed that the entire class of solidified wastes containing alpha-emitting radionuclides can be treated as having been solidified in concrete and packaged in the standard 210- $\ell$ drums. The source term for this form was computed as follows:

1. The bulk leach rate, $L_{n}\left(g / \mathrm{cm}^{2}\right.$. d), for concrete is in the range $10^{-9}$ to $10^{-1}$. For multivalent ions, a value of $10^{-4}$ is assumed (Aikens et a7. 1979). Measured incinerator ash incorporated in Portland cement are about $10^{-8}$ (Nielson, Colombo and Bradley 1981).

2. The fraction of radioactivity leached per drum/d, $L_{r}$, is determined by the equation, $L_{r}=L_{n}(S / M)$, where $S=$ surface area of monolith, and $M$ is its mass. For sludges, the ratio $S / M$ is about $6 \times 10^{-2}$ $\mathrm{cm}^{2} / \mathrm{d}$. Hence, the estimated fraction leached ranges from $L_{r}=6 \times$ $10^{-10} / \mathrm{d}$.

3. The geometry of the disposal cavity is of some significance in determining the source term magnitude, but more so for the unsolidified wastes to be considered later. The volume of Los Alanios solidified wastes can be readily accommodated as a single layer at the bottom of one of the larger disposal pit designs now in use at Area G (i.e., 30 $\mathrm{m}$ wide by $180 \mathrm{~m}$ long). Therefore, the equivalent of a single layer of 
drums of waste are contacted by a "band" of moisture moving through the disposal cavity. The contact time of this band depends on the seepage velocity of ter in the unsaturated materials in which the wastes are buried and on the porosity of the materials. With a poros$i$ ty of $25 \%$ and a seepage velocity of $0.01 \mathrm{ft} / \mathrm{d}(3 \mathrm{~cm} / \mathrm{d})$ in the zone of the waste drums, the contact time is $160 \mathrm{~d} / \mathrm{yr}$.

4. The last parameter needed to quantify the source term for the solidified class of waste is the activity per drum, $C_{d}$. Table $2-3$ gives one estimate of plutonium compositions found in TRU wastes.

A composite solidified waste form described by Roberts (1981) was used to develop an estimate of nuclide content per drum. The composite Los Alamos waste is assumed to be a product having a density of $1.8 \mathrm{~g} / \mathrm{cm}^{2}$ and a waste loading of $50 \mathrm{wt \%}$. The radionuclide content is assumed to result in a final product whose activity is no greater than $100 \mathrm{nCi} / \mathrm{g}$; for purposes of calculation, it is assumed to be $100 \mathrm{nCi} / \mathrm{g}$. To arrive at activity per drum under this constraint, the product of the weight fraction and specific (alpha emission) activicy of each component was summed to obtain an overall specific activity expressed as an alpha emission (Ci/g) (Table 2-3). However, the $241 \mathrm{Pu}$ specific activity was reduced to an equivalent $241 \mathrm{Am}$ activity. From the activity concentration in the mix of plutonium isotopes, the activity per drum of product can be estimated. The results are tabulated in Table 2-4.

TABLE 2-3. Composition of Plutonium Isotopes Expressed as Weight Fraction

\begin{tabular}{llcc} 
Nuclide & Defense Plutonium & Heat Source Plutonium & Ci/g \\
\cline { 3 - 4 } $238 \mathrm{Pu}$ & 0.0003 & 0.802 & 17.4 \\
$239 \mathrm{Pu}$ & 0.939 & 0.159 & 0.06 \\
$240 \mathrm{Pu}$ & 0.057 & 0.0302 & 0.23 \\
$241 \mathrm{Pu}$ & 0.005 & 0.0064 & 112.0 \\
$242 \mathrm{Pu}$ & 0.0003 & 0.0013 & 0.004
\end{tabular}


TABLE 2-4. Radioactivity per Drum in Los Alamos Solidified TRU Waste Activity/Drum (Ci)

\begin{tabular}{lll} 
Nuclide & Defense & Heat Source \\
\cline { 2 - 3 } $239 \mathrm{Pu}$ & $4.55 \times 10^{-2}$ & \\
$238 \mathrm{Pu}$ & $4.20 \times 10^{-3}$ & $5.08 \times 10^{-5}$ \\
$240 \mathrm{Pu}$ & $1.06 \times 10^{-2}$ & $7.46 \times 10^{-2}$ \\
$242 \mathrm{Pu}$ & $9.70 \times 10^{-6}$ & $3.69 \times 10^{-5}$ \\
$241 \mathrm{Am}$ & 1.67 & $2.67 \times 10^{-8}$ \\
& & $2.67 \times 10^{-8}$
\end{tabular}

The reievance of these concentration estimates to existing Los Alamos solidified waste can be roughly gauged by comparison with available data on concentration in stored waste, even though, of course, no attempt was made at the time of generation to produce a mixture having a predetermined radionuclide content. As the data in Table 2-5 reveal, there is good agreement with the average waste form.

It is difficult to unequivocally determine the number of "equivalent" $0.210 \mathrm{~m}^{3}$ drums of waste in this solidified waste class. Analysis of available data (Rogers 1977, Walker et al. 1981), shows about 2400 drums of 241 Am waste, 1200 of equivalent drums of defense plutonium waste, and about 2000 drums of heat source plutonilim.

TABLE 2-5. Comparison Between Computed Average Concentration and Measured Concentration of Defense Waste in Area $\mathrm{T}(\mathrm{Ci} / \mathrm{g})$

\begin{tabular}{|c|c|c|c|}
\hline Radionuclide & Typical & $\mathrm{High}$ & Computed \\
\hline $239 P u$ & $3.8 \times 10^{-} 2$ & $6.8 \times 10^{-2}$ & $4.6 \times 10^{-2}$ \\
\hline $238 \mathrm{Pu}$ & $3.8 \times 10^{-3}$ & $10.5 \times 10^{-3}$ & $4.2 \times 10^{-3}$ \\
\hline $241 \mathrm{Am}$ & 1.5 & 1.9 & 1.7 \\
\hline
\end{tabular}


Combining the data assumptions in 1 through 4 in this section, a source term $J_{0}$ can now be estimated using the following relation:

$$
J_{0}=t_{c} \cdot L_{r} \cdot N \cdot C_{d}
$$

where $t_{c}=$ contact time as fraction of a day

$L_{r}=$ the fraction of radioactivity leached per drum/d

$N=$ number of drums

$c_{d}=$ concentration per drum

The results are shown in Table 2.6 by using a leach rate of $6 \times 10^{-10} / \mathrm{d}$ for plutonium and $6 \times 10^{-6} / \mathrm{d}$ for americium.

\subsubsection{Source Terms for Unsolidified Waste}

The source terms for the unsolidified waste require a slightiy modified approach (Hansen and Rodgers 1983). The release of radioactivity from ordinary trash is not purely a diffusion-limited process as it is for

TABIE 2-6. Source Term ( $\mathrm{Ci} / \mathrm{yr}$ ) from Los Alamos Solidified TRU Waste

\begin{tabular}{|c|c|c|c|}
\hline Nuclide & Defense Waste & Heat Source & Sum \\
\hline $238 \mathrm{Pu}$ & $5.2 \times 10^{-5}$ & $9.8 \times 10^{-9}$ & $5 \times 10^{-5}$ \\
\hline $239 \mathrm{Pu}$ & $4.8 \times 10^{-6}$ & $1.4 \times 10^{-5}$ & $2 \times 10^{-5}$ \\
\hline $240 \mathrm{Pu}$ & $1.2 \times 10^{-5}$ & $7.1 \times 10^{-9}$ & $1 \times 10^{-5}$ \\
\hline $241 \mathrm{Pu}(24 \mathrm{Am})$ & $1.7 \times 10^{-5}$ & $2.3 \times 10^{-8}$ & $2 \times 10^{-5}$ \\
\hline $241 \mathrm{Pu}$ & $1.1 \times 10^{-8}$ & $5.1 \times 10^{-12}$ & $1 \times 10^{-8}$ \\
\hline $\begin{array}{l}241 \mathrm{Am} \\
\text { Urani um (a) }\end{array}$ & 3.8 & -- & 3.8 \\
\hline
\end{tabular}

(a) Uranium concentrations are difficult to estimate from data examined; we assume that most of the uranium source term is derived from the unsolidified category. 
waste/concrete mixtures. Instead, a host of complex processes involving microbial action, chemical reaction among various reagents mixed with the wastes, occur in the waste as it decomposes. Perhaps the best representation of the combined effect of all these sources is an empirical ratio of the concentration of specific radionuclides in radioactive-waste trench leachate to their concentration in the waste. Ratios of this type have been derived from Maxey Flats and West Valley data by 0ztunali et al. (1981). Their results expressed as average ratios are tabulated in Table 2-7.

The calculation of a contact time is identical with that before, except it is expressed as a fraction of the year: $t_{c}=0.43$.

The volume of leachate, $V_{w}$, produced by the deep percolation is estimated based on the area of the disposal cavity. The previously noted Area $G$ pit design of 30 by $180 \mathrm{~m}\left(5400 \mathrm{~m}^{2}\right)$ can be used here. The volume is therefore $V_{w}=648 \mathrm{~m}^{3}$.

The concentration of specific radionuclides in the disposal volume must also be estimated, this time as activity per unit volume. Again, there is no certain estimate of concentration average. However, for Area $C$, some inventory and volume estimates in Table 2-1 and summarized in Table 2-8 enable the concentration averages to be estimated.

TABLE 2-7. Average Leachate/Waste Ratios from Maxey Flats and West Valley Sites (empirically derived)

\begin{tabular}{ll} 
Nuclide & Leachate/Wast \\
\cline { 2 - 2 } $90 \mathrm{Sr}$ & $9.86 \times 10^{-3}$ \\
$241 \mathrm{Pu}$ & $4.67 \times 10^{-4}$ \\
$241 \mathrm{Am}$ & $4.11 \times 10^{-4}$ \\
$238 \mathrm{U}$ & $1.25 \times 10^{-4}$
\end{tabular}

On the basis of the above, source terms can be estimated by using a similar relation to that used for solidified waste:

$$
J_{0}=t_{c} \cdot M_{0} \cdot V_{w} \cdot C
$$


where $t_{c}=$ contact fraction

$M_{0}=$ leachate/waste concentration ratio

$V_{w}=$ water volume, $\mathrm{m}^{3} / \mathrm{yr}$

$C=$ concentration in waste, $\mathrm{Ci} / \mathrm{m}^{3}$

The resultant source terms are tabulated in Table 2-9.

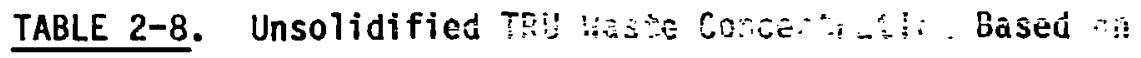
Area C Data

$\begin{array}{ll}\text { Nuclide } & \frac{\mathrm{Cj} / \mathrm{m}^{3}(\mathrm{a})}{} \\ 238 \mathrm{Pu}(\mathrm{b}) & 1.8 \times 10^{-5} \\ 239 \mathrm{Pu} & 2.0 \times 10^{-4} \\ 240 \mathrm{Pu} & 4.6 \times 10^{-5} \\ 241 \mathrm{Pu} & 6.4 \times 10^{-5} \\ 242 \mathrm{Pu} & 4.3 \times 10^{-8} \\ 241 \mathrm{Am} & 1.2 \times 10^{-3} \\ 233 \mathrm{U} & 3.8 \times 10^{-5} \\ 238 \mathrm{ug}^{(\mathrm{c})} & 5.3 \times 10^{-5} \\ 236 \mathrm{U} & 6.9 \times 10^{-5} \\ 235 \mathrm{U} & 1.0 \times 10^{-7} \\ 234 \mathrm{U} & 3.8 \times 10^{-5}\end{array}$

(a) Total pit volume estimated to be $1.3 \times 106 \mathrm{~m}^{3}$.

(b) Other $\mathrm{Pu}$ isotopes estimated from $238 \mathrm{Pu}$ data by assuming defense plutonium isotopic ratios.

(c) Uranium isotopes estimated from Area C arid Area $G$ data.

From a comparison of Table 2-6 and Table 2-9 values, the unsolidified wastes would be expected to contribute about one-tenth as much solidified waste to a release source terii, with the important exception of $239 \mathrm{Pu}$, which has a $50 \%$ increase from unsolidified waste. The sum of source magnitudes for each radionuclide was used for purposes of pathway analysis 
TABLE 2-9. Source Terms (Ci/year) for Los Alamos Unsolidified TRU Waste

Nuclide

$238 \mathrm{Pu}$
$239 \mathrm{Pu}$
$240 \mathrm{Pu}$
$241 \mathrm{Pu} \quad(241 \mathrm{Am})$
$242 \mathrm{Pu}$
$241 \mathrm{Am}$
$233 \mathrm{U}$
$234 \mathrm{U}$
$235 \mathrm{U}$
$236 \mathrm{U}$
$238 \mathrm{U}$

Source (Ci/yr)

$2.3 \times 10^{-6}$

$2.6 \times 10^{-5}$

$5.9 \times 10^{-6}$

$8.3 \times 10^{-6}$

$5.6 \times 10^{-9}$

$1.4 \times 10^{-3}$

$1.3 \times 10^{-6}$

$2.4 \times 10^{-6}$

$3.5 \times 10^{-9}$

$2.4 \times 10^{-6}$

$1.8 \times 10^{-6}$

on the assumption that the worst-case estimate will result from the disposal of both solidified and unsolidified TRU waste in the same or adjacent cavities.

\subsection{HAZARDOUS CHEMICAL WASTES}

Hazardous chemical wastes include inorganic and organic solids and liquids, and other solid and liquid residues contaminated with these chemicals. Approximately 9500 \& $(2500$ gal) of miscellaneous acids, bases, and organic chemicals; 9500 \& (2500 gal) of oils; and inorganic solutions resulting from chemical precipitation of fluoride and other wastes are disposed of yearly. In addition, batch wastes are often produced in small amounts, less than 200 \& (50 gal), which cannot be reduced or otherwise practically treated. Also requiring disposal are reactive metals, unusable or leaky gas cylinciers (empty or partially filled), capacitors, and other chemically contaminated equipment items.

These hazardous wastes are transported for disposal to a separately fenced area, Area L, located about $1.5 \mathrm{~km}(1 \mathrm{mi})$ from the radioactive waste 
burial Area $G$, on Mesita del Buey. Presently within this area, deep shafts and shallow trenches are used for disposal of the various categories of chemicals. Shafts typically measure 0.6 to $1.8 \mathrm{~m}(2$ to $6 \mathrm{ft}$ ) in diameter by $15 \mathrm{~m}$ (50 ft) deep, and all are equipped with personnel safaty covers. Separate shafts are used for the disposal of different categories of waste chemicals. These categories are acids, bases, organics, inorganics, and reactive metals. Separate shafts alsc are used for gas cylinders and drums containing bulk waste oils and solvents. Containers of these latter wastes are lowered into the appropriate- shafts. Bulk inorganic salt solutions are disposed of into a sha!low trench to allow evaporation of the water content. Fill dirt is periodically applied to each if the shafts and trenches receiving wastes as a tasic precautionary measure against fire or dispersal. Where wastes are too large or bulky for disposal in the chemical disposal area, disposal is accomplished at the radioactive waste site nearby, with adequate provision for isolation from radioactive wastes.

\subsection{DECONTAMINATION AND DECOMMISSIONING}

Wastes from decontamination and decommissioning operations are handled by established procedures and buried within Area $G$.

- TA-1. Between 1943 and 1965, research work on nuclear weapons was carried out in TA-1. The area was decontaminated and demolished in stages, and beginning in 1966 the lana was given to Los Alamos County or sold to private interests. A resurvey in 1974 disclosed traces of radioactive contamination undetected or considered insignificant during original demolition in the 1950 s and 1960s. The remaining contamination was removed in 1975 and 1976 to levels considered to pose no health or safety hazards. As a result of the decontamination efforts, $\sim 15,000 \mathrm{~m}^{3}$ of contaminated or potentially contaminated soil and debris were removed to Area G (Ahlquist, Stoker and Trocki 1977).

- Experimental Incinerator. An old experimerital incinerator facility was decommissioned and the site completely decontaminated (U.S. EROA 
1977. Harper and Garde 1978 and 1981a). The site was decontaminated to conditions considered as low as practicable to achieve, which resulted in no penetrating radiation detectable above natural background and detectable alpha radioactivity at less than $20 \mathrm{pCi} / \mathrm{g}$ above natural background. The site remains within the Los Alamos boundary.

- DP Plutonium Facility ana Tritium Facility. Building decontamination operations are completed on the old TA-21 DP Plutonium Processing Facilicy and on a tritium handling facility (Christensen, Garde and Valentine 1975; Garde, Cox and Valentine 1984; Harper and Garde 1981b; Harper and Garde 1981c).

\subsection{EFFLUENT IMPACT ON CANYONS}

The four canyon areas where liquid wastes have been discharged are the subjects of continuing studies on the chemical and radiochemical quality of water and sediments. The studies include those conducted for monitoring purposes as well as special investigations regarding the behavior of lowlevel contaminants in the environment. The canyons continue to receive low levels of contamination.

The canyons include Bayo, Pueblo, Los Alamos, and Mortardad and are shown in Figure 2.1. Pueblo Canyon received untreated radioactive wastes between 1944 and 1951 and treated radioactive effluents between 1951 and 1964. Los Alamos Canyon has receiyed treated effluents since 1952. Mortandad Canyon has received treated radioactive effluents since 1963. Figure 2.2 indicates the location of former and current major discharge points as well as the various sampling locations and test holes utilized to develop information on the environmental conditions.

In the two canyon areas presently receiving treated effluents (upper Los Alamos and Mortandad), the basic conditions are similar. Under typical dry conditions, the effluent stream flows on the surface for distances of about 0.3 to $0.5 \mathrm{~km}(0.2$ to $0.3 \mathrm{mi})$ before infiltrating into the channel alluvium. During periods of precipitation run-off or snowmelt, this distance may be extended. In Los Alamos Canyon and its tributary Puebio Canyon, heavy precipitation may result in flow all the way to the Rio Grande about four times a year. All flow in Mortandad Canyon since at 


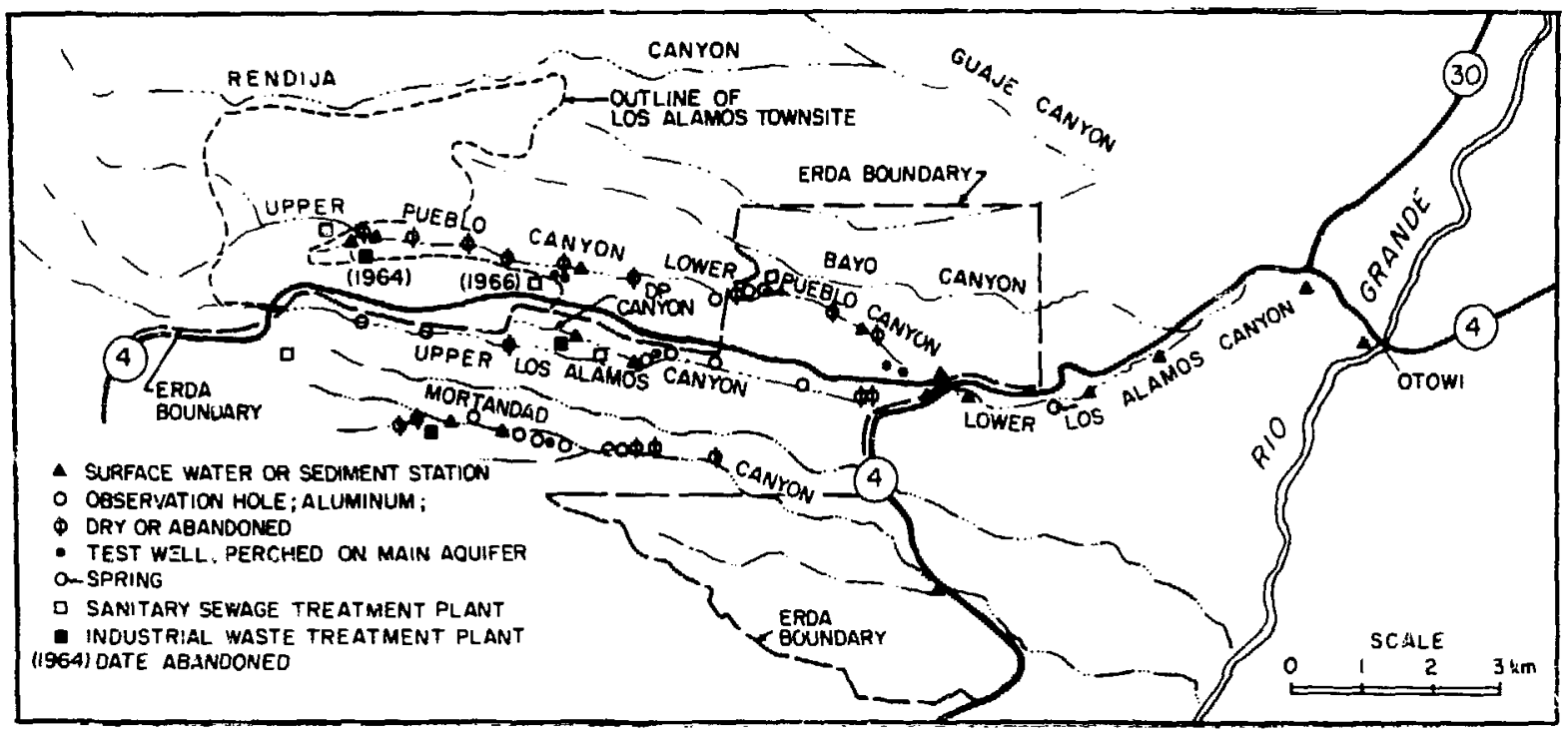

FIGURE 2.1. Canyon Water and Sedimenc Sampling Locations with Current and Former Major Effluent Discharge Points.

least 1960 has infiltrated into the alluvium before reaching the DOE boundary some $5 \mathrm{~km}$ ( $3 \mathrm{mi})$ downstreain from the discharge point.

The effluents and natural run-off infiltrate into the alluvium, recharging the shallow perched water bodies. The majority of the radioactivity is adsorbed onto the sediments. The adsorption, coupled with dilution by natural run-off, results in very low concentrations of radioactivity in the water contained within the alluvium, only fractions of a per cent permitted by concentration guides in drinking water. As the water moves downstream, in the form of surface flow aild as ground water in the alluvium, concentrations decrease.

The adsorption of the radionuclides results in a buildup on the sediments near the discharge point. However, transport of the sediments by snowmelt and summer storm run-off events tends to redistribute the sediments and adsorbed radionuclides over a wider area. The highest concentration of radionuclides is assoclated with silt- and clay-sized particles in he sediments. However, these small particles make up less than $10 \%$ of the mass of the alluvium. Therefore, most of the radioactivity is associated 
with the larger-sized sediment particles. The larger particles are transported as bed load that moves more slowly than the suspended material and travels shorter distances downstream with each run-off event. The amount of material moved with each run-off event varies greatly, depending on the flow rate, the volume of run-off, the location within the canyon, and other factors. This transport process produces an irregular variation in radionuclide concentrations in the sediments within the various canyons and is responsible for some offsite transport of radioactivity in Pueblo and Los Alamos canyons.

Information on the types and quantities of radioactivity released to the four canyon areas has been compiled from estimates and official records. During the early years, either no records or very limited information was kept on quantities of releases. Thus, many of the values used for early periods are only estimates. In more recent years, increasingly detailed information has been recorded (Purtymun 1971; Purtymun, Peters and Stoker 1980).

During 1978, extensive additional field sampling and measurements were completed in Bayo, Acid/Pueblo, and lower Los Alamos canyons under auspices of the DOE Formerly Utilized Sites Remedial Action Program (FUSRAP).

- Bayu Canyon was used between 1944 and 1961 as a site for experiments employing conventional high exflosives in conjunction with research on nuclear weapons deveiopment. The explosive detonation resulted in the dispersion of radioactive materials--uranium, 140La, and $90 \mathrm{Sr}--i$ in the form of aerosols and debris to the atmosphere and onto the ground around the firing points. Radiochemistry operations conducted at the site resulted in the generation of liquid and solid radioactive wastes, which were disposed of into subsurface pits and leaching fields.

The Bayo Canyon site was decommissioned by 1963 with the removal or demolition of structures, cleanup of surface debris, and excavation of contaminated waste disposal facilities. Radiological surveys resulted in the conclusion that the site was sufficiently free of contanination to permit the land to be released from federal government control. 
The 1978 resurvey results showed that residual surface contamination due to $90 \mathrm{Sr}$ averaged about $1.4 \mathrm{pCi} / \mathrm{s}$ or approximately three times the level attributable to worldwide fallout. Surface uranium averaged about $4.9 \mu \mathrm{g} / \mathrm{g}$ or about 1.5 times the amount naturally present in the volcanic-derived solls of the area. Subsurface contamination associated with the former waste disposal locations is largely confined within a total area of about $10,000 \mathrm{~m}^{2}$ and down to depths of about $5 \mathrm{~m}$. Of 378 subsurface samples, fewer than $12 \%$ exceeded $13 \mathrm{pCi} / \mathrm{g}$ of gross beta activity. which is comparable with the upper range of activities for uncontaminated local solls (U.S. DOE 1979b, Ferenbaugh et al. 1982a).

- Acid, Pueblo, and Los Alamios Canyons. Current radiological conditions were evaluated for the site of a former radioactive liquid waste treatment plant $(T A-45)$ and the interconnected canyons that received both treated and untreated efflueils between 1944 and 1951. After fecommissioning of the treatment plant and decontamination of the site and part of one canyoii, ownership of some of the lanj in question was transferred to Los Alamos County in 1967. A 1980 resurvey showed that some residuai radioastivity attributable to the effluents remained and is found on soils and sediments at the former plant site and in the channels of the canyons (U.S. DOE 1981 and Ferenbaugh et al. 1982b). 


\section{REFERENCES}

Ahlquist, A. J., A. K. Stoker and L. K. Trocki. 1977. Radiological Survey and Decontamination of the Former Main Technical Area TTA-I) at LoS Alamos, New Mexico. LA-6887-MS, Los Alamos Scientific Laboratory, Los Alamos, New Mexico.

Aikens, A. E., Jr., R. E. Berlin, J. Clancy and 0. I. Oztunali. 1979. Generic Methodology for Assessment of Radiation Doses from Ground Water Migration of Radionuclides in LWR Hastes in Shallow Land Burial Trenches. AIF/NESP-013, Washington, DC.

Christenson, E. L., R. Garde and A. M. Valentine. 1975. Demolition of Building 12, an 01d Plutonium Filter Facility. LA-5755, Los Alamos Scientific Laboratory, Los Alamos, New Mexico.

Ferenbaugh, R. W., T. E. Buh1, A. K. Stoker and W. R. Hansen. 1982a. Environmental Analysis of the Bayo Canyon (TA-10) Site, Los Alamos, New Mexico. LA-9252-MS, Los Alamos National Laboratory, Los Alamos, New Mexico.

Ferenbaugh, R. ",, T. E. Buhl, A. K. Stoker and W. R. Hansen. 1982b. Environmental Analysis of Acid/Middle Pueblo Canyon, Los Alamos, New Mexico." LA-9409-MS, Los Alamos National Laboratory, Los Alamos, New Mexico.

Garde, R., E. J. Cox and A. M. Valentine. 1984. Los Alamos DP West Plutonium Facility Decontamination Project 1978-1981. LA-9513-MS, Los ATamos National Laboratory, Los Alamos, New Mexico.

Hansen, W. R., and J. C. Rodgers. 1983. "Risk Analyses for Shallow Land Burial and Greater Confinement of Alpha-Contaminated Waste." Nuclear and Chemical Waste Management 4:81-94.

Harper, J., and R. Garde. 1978. The Decontamination of a 239-P1utonium Contaminated Incinerator Facility. Presented at the International Symposium on Decontamination of Nuclear Facilities, Vienna.

Harper, J. R., and R. Garde. 1981a. The Decommissioning of the TA-42 Plutonium Contaminated Iricinerator Facility. [A-9077-MS, LOS ATamos National Laboratory, Los Alamos, New Mexico.

Harper, J. R., and R. Garde. 1981b. The Decommissioning of TA-21-153, A 227AC Contaminated 01d Filter Building. LA-9056-MS, Los Alamos Kational Laboratory, Los Alamos, New Mexico.

Harper, J. R., and R. Garde. 1981c. The Decommissioning of a Tritium Contaminated Laboratory. LA-9056-MS, Los Alamos National Laboratory, Los Alamos, New Mexico. 
Neilson, R., P. Colombo and I. D. Bradley. 1981. "Plutonium Leachability from Alternative Transuranic Incinerators Ash Waste Forms." In Management of Alpha-Contaminated Wastes. IAEA-SM-246.

Oztunali, 0. I., P. M. Moskowitz, E. D. Picazo and C. J. Pitt. 1981. Data Base for Radioactive Waste Management NUREG/CR-1759, Vo7. 3, Nuclear Regulatory Commission, Washington, DC.

Purtymun, W. D. 1971. Plutonium in Stream Channel Alluvium in the Los Alamos Area, New Mexico. LA-4561, Los ATamos Scientific Laboratory, Los Alamos, Hew Mexico.

Purtymun, W. D., R. Garde and R. Peters. 1978. Movement of Fluids and Plutonium from Shafts at Los Alamos, New Mexico. LA-7379-MS, Los ATamos Scientific Iaboratory, Los ATamos, New Mexico.

Purtymun, W. D., R. J. Pecters and A. K. Stoker. 1980. Radioactivity in Soils and Sediments in and Adjacent to the ! Is Alamos Area, 1974-1977. LA-8234-MS, Los ATamos Scientific Laboratory, Los Alamos, New Mexico.

Purtymun, W. D., M. A. Rogers and M. L. Wheeler. 1980. Radiochemical Analyses of Samples from Beneath a Solid Radioactive Waste Disposal Pit at Los ATamos, New Mexico. LA-8422-MS, Los ATamos Scientific Laboratory, Los Alamos, New Mexico.

Roberts, F. P. 1981. An Assessment of Radiation Effects in Defense Tranuranium Waste Forms. PNL-3913, Pacific Northwest Laboratory, Richland, Washington.

Rogers, M. A. 1977. History and Environmental Setting of LASL Near-Surface Land Disposal Facilities for Radioactive Wastes. LA-6973-MS, VoT. I, Los ATamos Scientific Laboratory, Los Alamos, New Mexico.

U.S. D0E. 1979a. Final Environmental Impact Statement, Los Alamos Scientific Laboratory Site, Los Alamos, New Mexico. DOE/EIS-0018, U.S. Department of Energy, Washington, $D C$.

U.S. DOE. 1979b. Radiological Survey of the Bayo Canyon, Los Alamos, New Mexico. DOE/EV-0005/15, U.S. Department of Energy, Washington, DC.

U.S. DOE. 1981. Radiological Survey of the Site of a Former Radioactive Liquid Waste Treatment PTant (TA-45) and the Effluent Receiving Area of Acid, Pueblo, and LOS ATamos Canyons. D0E/EV-0005/30, U.S. Department of Energy, Washington, DC.

U.S. ERDA. 1977. Environmental Assessment for Decommissioning of the TA-42 Inc inerator Facility and the TA-21-153 filter Buitding at LASL. EIA/ECT/77-3, U.S. Energy Research and Development Administration. 
Walker, L., et al. 1981. Alternative Transuranic Waste Management Strategies at Los Alamos National Laboratory. LA-8982-MS, Los ATamos National Laboratory, Los Alamos, New Mexico.

Warren, J. W. 1980. "Shallow Land Burial: Experience and Developments at Los A? amos." In Underground Disposal of Radioactive Wastes 1:221-240. IAEA SM-243/150. 


\subsection{PATHWAYS AND JUSTIFICATION}

\subsection{PATHWAYS FOR SOILS AND SEDIMENTS}

The studies by Healy 1977; Healy and Rodgers 1979; and Heaiy, Rodgers and Weinke 1979 established the major pathways to man from soil and buried wastes. Soil and sediment patitiay analyses were made for the FUSRAP program by using the radiological survey data from Bayo, Acid, Pueblo, and Los Alamos Canyons. These studies assumed pathways to the worker and the pilation from contaminated soils and sediments from external radiation, general resuspension of soil, beef cattle food chain, transport into the Rio Grande food chain, and the gardening food chain pathway (U.S. DOE 1981).

- External Penetrating Exposure Pathway. The external penetrating radiation ( $x$ - and gamma-ray) dose attributable to above background concentrations of contaminants can be theoretically calculated to varying degrees of accuracy by using standard methods. The basic approach was to estimate the doses as being from a theoretical infinite plane with the radioactivity distributed vertically according to an exponential curve. Dose factors giving the 5 - $\mathrm{cm}$-depth dose in tissue at $1 \mathrm{~m}$ above a plane with uniform surface distribution of radioactivity were taken from U.S. Energy Research and Development Administration (1977) data. These factor's were adjusted to account for an exponential distribution with depth below the surface having a relaxation length of $10 \mathrm{~cm}$ and to account for absorption and scattering of different energies down to $100 \mathrm{keV}$ (Beck, De Campo and Gogolak 1972). The areal concentrations $\left({ }_{\mu} \mathrm{Ci} / \mathrm{m}^{2}\right)$ for the canyon strata were calculated by taking the highest channel or bank iverage in the stratum for $239 \mathrm{Pu}, 137 \mathrm{Cs}$, and $234 \mathrm{U}$ and assuming it persisted for a $30-\mathrm{cm}$ depth. These areal concentrations were multiplied by the appropriate dose and depth distribution factors to obtain the estimated whole-body dose rates.

- General Resuspension. The residual contamination on the soll and bank sediments provides a source of particulate matter that may be 
resuspended by wind movement or other mechanical action. Such airborne particulate matter could be inhaled by persons occupying the canyon areas for various proportions of time or, at probably lower dilutions, by the normal inhabitants of the Los Alamos area. Direct measurements of total airborne radioactivity have been made in the Los Alamos area for a number of years as part of the Los Alamos National Laboratory routine environmental monitoring program (Environmental Surveillance Group 1985) (Section 1.3.2). Another method of evaluating the potential contribution of resuspension of residual contamination is described here. The theoretical model selected is the straightforward mass-loading approach, which is suitable for conditions where the contaminant has been aged in the environment for some time (US Environmental Protection Agency 1978). Refinements to account for unequal distribution of the contaminant on different particle sizes and for the limited size of the contaminated area were ircluded. The basic approach predicts the concentration of airborne activity (activity per unit volume of air) as the product of the mass of particulates in the air (mass per unit volume of air) and the concentration of activity on the soil (activity per unit mass of soil) in the area. This predicted air concentration is modified by an enrichment factor to account for the generally higher concentration per unit mass on smaller particles in the respirable range and for the generally small weight fraction of small particles in soils. The final modification is an attempt to account for the relatively small proportion of the canyon bottom area occupied by the contaminated stream channel and banks. This was done by multiplying by the ratio of the area of the stream channel or banks to the horizontal projection of the overal1 canyon area.

The annual average mass loading was $35 \mu \mathrm{g} / \mathrm{m}^{3}$ based on measurements made in the Los Alamos townsite by the New Mexico Environmental Improvement Division. This value is an annual geometric mean. Monthly geometric means typically range from about 20 to $60 \mu \mathrm{g} / \mathrm{m}^{3}$; daily measurements typically range from about 10 to $150 \mu \mathrm{g} / \mathrm{m}^{3}$.

- Beef Cattle Food Pathway. In lower Los Alamos Canyon, cattle are often grazed, especially in the spring. $\therefore$ food chain analysis was 
made to estimate the potential exposure to humans through this pathway. The largest potential uptake would occur during years when spring snowmelt results in continuous flow in the stream channel for an extended period and cattle stay near the river more consistently. For dose calculation the assumptions were that a beef steer obtained all its water and vegetation for 3 months during the spring of each of 2 years from lower Los Alamos Canyon. On the basis of measurements, the soils were assumed to have about $2 \mathrm{pCi} / \mathrm{g}$ of $239 \mathrm{pu}$ and the water an average of about $5 \mathrm{pCi} / 2$ of $239 \mathrm{Pu}$, including that on suspended sediments. Uptake modeling parameters, including that for soil ingested on vegetation surfaces (which represents the majority of the intake), were based on experimental studies.

- Transport into Rio Grande. Some sediments are transported into the Rio Grande from lower Los Alamos Canyon during run-off from large spring snowmelt and summer thurdershower events. There must be some input of radioactivity from Los Alainos Canyon into the Rio Grande during such events, but the theoretically calculated dilution confirmed by actual measurements shows that the increments are small, usualiy at or below detection limits and less thari the measured variability from natural distribution. Nevertheless, measurements have been made of fish and other foodstuffs to document actual levels of potential contaminants in the pathways.

Analyses of fish muscle samples collected yearly showed no statistical differences between radioactivity $\left(137 \mathrm{Cs}, 238^{-} 239 \mathrm{Pu}\right.$, and total uranium) in fish at Cochiti lake on the Rio Grande below the confluence with Los Alamos Canyon, Heron and El Vado Reservoirs on the Rio Chama (a tributary of the Rio Grande), and Costilla Lake (a high mountain lake in northern New Mexico).

Uranium analyses of the eight sediment samples taken in 1979 from the Rio Grande, both above and below the confluence with Los Alamos Canyon, were similar and were statistically higher than the single sample taken from the Rio Chama. However, concentrations of dissolved uranium were higher in water from the Rio Chama than from the Rio Grande. Uranium in sediments from the Rio Grande was about the same as from Los Alamos Canyon, indicating no significant input from Los 
Alamos Canyon because of the much greater mass of sediments carried in the Rio Grande.

During the 8 years of foodstuff monitoring, foodcrops grown using th.e water from the Rio Grande at Cochiti have not shown any statistically significant differences in radioactivity concentrations from crops grown with river water from the Rio Grande and Rio Chama above the confluence with Los Alamos Canyon (Envirormental Surveillance Group 1985). Analyses were done for $238^{-239 P u}$, tritiated water, and total uranium in all years, and in later years $90 \mathrm{Sr}$ was included. No measurable effect from released effluents was measured in the food chain pathways along the Rio Grande.

Potential doses to hypothetical future residents wolild include those from external penetrating radiation and general resuspension exposure as discussed above. Additional exposures considered possible were those due to extra inhalation of dust resuspended during home garden tilling or to ingestion of produce grown in the contaminated soils.

- Construction Worker. For estimating the exposure of a construction worker, the basic assumptions were taken to be a high breathing rate associated with physically demanding labor, $43 \mathrm{l} / \mathrm{min}$, and very dusty conditions where the airborne particulate concentration is $10 \mathrm{mg} / \mathrm{m}^{3}$, the present thres': old limit value for nuisance dust.

- Gardening. The dose to a home gardener during rototilling and soil preparation was estimated with the same basic assumptions as used for a construction worker in terms of breathing rate, suspendei particulate concentration, enrichment factor, activity ratios, ard dose factors. The soil concentration was taken to be half of that for banks, by assuming that the sandy soil present would be mixed with other loamy soil or organic amendments in the ratio of $1: 1$ to support reasonable growth. The soil preparation time was assumed to be 30 hours for a growing season.

Fur consumption of produce, the same assumption regarding soil concentration was made. iransfer factors for specific isotopes were taken from U.S. Energy Research and Development Administration (1977) data. An annual intake of fresh produce of $46.5 \mathrm{~kg}$ was taken 
from U.S. Department of Agriculture (1978) data and assumed to De complstely supplied from the garden.

\subsection{PATHWAYS FOR BURIED WASTES}

Because TRU wastes were buried in shallow land burial before 1970 , efforts to assess the significance of current and lorig-term risks from these wastes were initiated oy DOE (Walker et al. 1981, Hansen and Rodgers 1983).

The assessment of alternatives for Los Alamos included 14 major possible management strategies (Walker et a1. 1981). Severai of the alternatives included management strategies of leaving the wastes in place or with improved confinement. The public health risks for thuse alteruatives were evaluated for the probability of ragivactivity release for severai scenarios. The probability of release included consideration of near-term releases during a period les: than 100 years, long-term releases, and releases by accidents or catastrophic events. General release mechanisms for buried wastes include intrusion by plants or anima1s, humans, water infiltration, erosional processes, and combinations of the above. Probabilities for catastrophic events such as earthquakes, volcanism, or plane crashes were determined, but other mechanisms involving biotic or hunan intrusion were assigned probabilities of 1 for long-term considerations (greater than 100 jears without special controls on the waste areas).

Buried waste was analyzed for the release potential from accidents and natural phenomena. The analysis considered the volume of waste, curie content, and events that could lead to a release (Wheeler, Smith and Ga1legos 19:7; Walker et a1. 1981).

- Tornado. There is an extremely low probability of tornadoes at Los Alamos. Tornadoes with winds 158-206 mph are deenied impossible. Winds of 113-157 mph have a probability of about $1.5 \times 10^{-6} /$ year, a value on the borderiine of credibility.

- Airplane Crash. Smail releases are postulated for an airplane penetrating a temporary waste storage building and causing an aviation fuel waste debris fire. The estimated probabtlities range from $1.6 \times$ $10^{-1}+$ year to $2.3 \times 10^{-7}$ /year (Wall 1974). 
- Operator and/or Equipment Failure. Oropping containers during a waste assay, an incinerator explosion, or waste emplacement are the most likely accidents that could lead to a release.

- Earthquake. This event was dismissed from consideration after careful scrutiny of available information. Studies by Budding and Purtymun (1976) and Sanford (1976) estimate that the Los Alamos area is subject to an earthquake of magnitude from 5 to 5.5 (Richter scale) once every 100 years. An equally important consideration is what might occur in Los Alamos during earthquakes. In the design of the new plutonium facility, a modified Mercalli scale intensity of VII was chosen for the "Operating Base Earthquake," and an interisity value of VIII on the same scale was chosen for the "Safe Shutdown Earthquake." Although there is no single relationship between Richter magnitude and the modified Mercalli Intensity, the following is noted for purposes of illustration: a 5- to 5.5-magnitude, VII- to VIII-intensity earthquake would probably cause nonseismically qualified structures considerable damage. For waste operations, it is estimated the disturbance would cause damage severe enough to break containers. However, release of radioactively contaminated material is unlikely and, if it did occur, would be confined to the immediate area with ro significant release to the environment. In addition, because the most probable epicenter for an earthquake at Los Alamos is the Pajarito fault ( 5 to $12 \mathrm{~km}$ distant from the waste sites analyzed), the severity of the most probable earthquake at Los Alamos would be lessened by the distance from the waste site. The earthquake scenario does not present a credible mechanism for release of radioactive material from the waste burial or storage areas analyzed.

- Volcano. The probability for volcanic activity at any of the Los Alamos burial grounds is extremely low, so it is dismissed from consideration (US DOE 1979).

- Flood. No credible flood event would effect a release of Los Alamos buried waste (US DOE 1979).

- Meteorite. A meteorite was dismissed from consideration because the estimated probability is $1 \times 10^{-7}$ iyear. 
Biotic and human intrusion scenarios (Healy 1977) involve mechanisms that bring wastes to the surface followed by human inhalation or ingestion of the radioactive materials. Biotic intrusion is assumed to be natural succession of plants culminating in a reforestation of the waste araa. Transuranium elements would be brought to the surface by root uptake and deposition of dead plant materials where inadequate cover material has been placed over buried waste. Animals common to the area can burrow and also bring materials to the surface as otserved at present sites by Rogers (1977).

Human intrusion scenarios included consideration of activities of urbanization, agriculture, and resource exploration. Urbanization included utility trenches, drives and roads, gardens, lawns, commercial properties, and parks. Agricultural scenarios inciuded crops and pastures. Resource exploration scenarios included drilling for minerals or water, and possible archaeological explorations. For each scenario, a source term was derived from the records of wastes disposed of in the active or inactive areas.

The data from Walker et al. (1981) and Hansen and Rodgers (1983) for a waste disposal site in use before 1970 was taken as an example of a source term for shallow land burial greater than $100 \mathrm{nCi} / \mathrm{g}$ of TRU wastes. The example used was Los Alamos Waste Area C, which was used before 1970. The area covered is 12 acres (about 50 ha). During operation of the area, data from a 9-month study of wastes generated by the plutonium facilities indicated a range of TRU wastes as listed in Table 3-1 (Los Alamos Scientific Laboratory 1976). These TRU wastes were further diluted by $1 \mathrm{cw}-$ level wastes from other laboratory facilities. For scenarios that include intrusion into the whole area for crops, pasture, parks, or natural succession, an average of $0.1 \mathrm{nCl} \mathrm{TRU} / \mathrm{g}$ was estimated.

For scenarios such as inadvertent or deliberate human intrusion with excavation of waste, the source term was estimated as a possible range. Values used were $0.1 \mathrm{nCi} \mathrm{TRU} / \mathrm{g}$ for an average and $250 \mathrm{nCi} \mathrm{TRU} / \mathrm{g}$ for the highest value. Source terms estimated included the possible dispersal, dilution, or translocation of TRU-contaminated materials by the land use under consideration. Potential land uses were screened by guidance based on soils, climate, and water availability (Rogers 1980). Source terms estimated for each waste area were then used to estimate the amount of TRU elements that could follow environmental pathways to man. 
TABLE 3-1. Per Cent of TRU Wastes from the Los Alamos Plutonium Faci?ity

\begin{tabular}{rl}
\multicolumn{1}{c}{$\mathbf{q}$} & $\mathrm{nCi} / \mathrm{g}$ \\
91 & $<1$ \\
5 & $1-10$ \\
2 & $10-100$ \\
2 & $100-5000$
\end{tabular}

The pathways for radionuclides to man were developed from the mechanisms causing irhalation or ingestion. Inhalation pathways would be from air contamination from resuspension. Local resuspension during intrusions, such as inadvertent trenching into the waste, would be short in duration, but may result in higher air concentrations. Ingestion pathways include root uptake by plants, foliar contamination of plants by airborne particles, animal products from agricultural practices, and water. Further details of the parameters used for the pathway to man are discussed in the reports by Walker et al. (1981) and Hansen and Rodgers (1983).

Removing wastes from the action of erosion increases the possibility of bringing them closer to subsurface water and the corresponding hydrologic exposure pathways. At Los Alamos, however, the ground water pathway is not usually considered likely to be a significantly limiting pathway. Because even with burial at depths of about $100 \mathrm{~m}$, there remains over $200 \mathrm{~m}$ of unsaturated tuff remain between the waste and the aquifer.

However, the tuff at Los Alamos is known to be quite heterogeneous, highly fractured, and jointed, precisely the conditions under which the straightforward application of ground water diffusivity equations are most uncertain. Within several meters of the mesa surface, these fractures are filled with clays (Walker et al. 1981), which tend to seal the fracture against, further downward moisture movement. Below $10 \mathrm{~m}$, the joints are commonly open, and show little or no evidence of weathering. Numerous soil moisture measurements at depth reveal that the water content of the tuff is quite low below $5 \mathrm{~m}$ of depth, usually at $15 \%$ of saturation or less. At this water content, water movement occurs exclusively as unsaturated flow 
in the fissures if sufficient water were present to fill the fracture, but the absence of weathering below about $10 \mathrm{~m}$ indicates this is the maximum depth to which saturated water flow has penetrated in significant quantities under conditions typical of the history of the Los Alamos environs. 


\section{REFERENCES}

Beck, H. L., J. De Campo and C. Gogolak. 1972. In Situ Ge(Li) and NaI (Tl) rian-i-Ray Spectroscopy. HASL-258, U.S. DOE Health and Safety Laboratory, New York, New York.

Budding, A. J., and W. D. Purtymun. 1976. Sejsmicity of the Los ATamos Area Based on Geologic Data. LA-6278-MS, Los Alamos Scientific Labortory, Los ATamos, New Mexico.

Environmental Surveillance Group. 1985. Environmental Surveillance at LoS Alamos During 1984. LA-10421-ENV, Los ATamos Nationat Laboratory, Los Alamos, New Mexico.

Hansen, W. R., and J. C. Rodgers. 1983. "Risk Analyses for Shallow Land Burial and Greater Confinement of Alpha-Contaminated Wastes." Nuclear and Chemical Waste Management 4:81-94.

Healy, J. W. 1977. An Examination of the Pathways from Soil to Man for P7utonium. LA-6741-MS, Los ATamos Scientific Laboratory, Los ATamos, New Mexico.

Healy, J. W., J. C. Rodgers, and C. L. Wienke. 1979. Interim Soil Limits for D\&D Projects. LA-UR-79-1865-Rev, Los ATamos Scientific Laboratory, Los ATamos, New Mexico.

Healy, J. W., and J. C. Rodgers. 1979. Limits for the Burial of Department of Energy Transuranic Wastes. LA-UR-79-100, Los ATamos Scientific Laboratory, Los Alamos, New Mexico.

Los Alamos Scientific Laboratory. 1976. Transuranic Solid Waste Management Progress Report, July-December 1975. LA-6481-PR, Los Alamos Scientific Laboratory, Los Alamos, New Mexico.

Rogers, J. L. 1980. Land Use Classification System. RAE-6-1, Report \pm 0 Los Alamos National Laooratory by Rogere and Associates Engineering Corporation, Salt Lake Sity, Utah.

Rogers, M. A. 1977. History and Environmental Setting of LASL Near-Surface Disposal Facilities for Radioactive Wastes. LA-6848-MS, Los Alamos Scientific Laboratory, Los Alamos, New Mexico.

Sanford, A. R. 1976. Seismicity of the Los Alamos Region Based on Seismo?ogical Data. [A-6416-MS, Los Alamos Scientific Laboratory, Los Alamos, New Mexico.

U.S. Departinent of Agriculture. 1978. Food Consumption, Prices, Expenditures. Supplement for 1976 Agricultural Economic Report 138. 
U.S. Department of Energy. 1979. Final Environmental Impact Statement-Los Alamos Scientific Laboratory Site, LoS Alamos, New Mexico. DOE/EIS0018, Los Alamos Scientific Laboratory, Los Alamos, New Mexico.

U.S. Energy Research and Development Administration. 1977. A Guide for Environmental Radiological Surveillance at ERDA Institutes. 77-24, U.S. Energy Research and Development, Washington, DC.

U.S. Environmental Protection Agency. 1978. Selected Topics: Transuranic Elements in the General Environment. ORP/CSD-78-1, 0ak Ridge National Laboratory, Oak Ridge, Tennessee.

U.S. Department of Energy. 1981. Radiological Survey of the Site of a Former Radioactive Liquid Waste Treatment PTant (TA-45) and the EffTuent Receiving Areas of Acid, Pueb7o, and Los A7amos Canyon, LOS A7amos, New Mexico. DOE/EV-0005/30, LA-8890-ENV, Los A7amos National Laboratory, Los ATamos, New Mexico.

Walker, L. J., et al. 1981. Alternative Transuranic Waste Management Strategies at Los Alamos National Laboratory. LA-8982-1IS, Los Alamos National Laboratory, Los Alamos, New Mexico.

Wall, I. B. 1974. "Probabilistic Assessment of Aircraft Risk for Nuclear Power Plants." Nuclear Safety 15:270-284.

Wheeler, M. L., W. J. Smith and A. F. Gallegos. 1977. A Preliminary Evaluation of the Potential for Plutonium Release from Burial Grounds at Los ATamos Scientific Laboratory. LA-6696-MS, Los ATamos Scientific Laboratory, Los ATamos, New Mexico. 


\subsection{ENVIRONMENTAL DOSIMETRY}

\subsection{ENYIRONMENTAL DOSE CALCULATIONS}

The analyses in this section are used for the environmental effects of the Laboratory as a whole, which include those done for the LLW sites. The waste disposal sites contribute an extremely small increment to the already small effects calculated for all the Laboratory operations.

Annual radiation doses are evaluated for three principal exposure pathways: inhalation, ingestion, and external exposure (which includes exposure from immersion in air containing radionuclices and direct and scattered penetrating radiation). Results of environmental measurements are used as much as possible. Calculations based on these measurements follow procedures recommended by federal agencies to detemine radiation doses (U.S. DOE 1981, U.S. NRC 1977).

Estimates are made of the

1. Maximum boundary dose to a hypothetical individual at the Laboratory boundary where the highest dose rate occurs. It assumes the individual is outside at the Laboratory boundary continuously (24 h a day, 365 days a year).

2. Maximum individual dose to an individual at or outside the Laboratory boundary where the highest dose rate occurs and where there is a person. The estimate takes into account occupancy (for example, 40 $h$ a week) and shielding (for example, by buildings) factors.

3. Average doses to nearby residents.

4. Whole-body person-rem dose for the population living within an $80-\mathrm{km}$ radius of the Laboratory.

Four age groups ara considered: infant, child, teen, and adult. Dose calculations utilize parameters (U.S. NRC 1977, ICRP 1974, Environmental Surveillance Group 1983) such as annual food consumption and breathing rates specific to each age group. 
Age-specific dose conversion factors used for inhalation and ingestion calculations are also in the Environmental Surveillance Group (1985) report (Sections 1.3.2 and 1.3.3). Doses are calculated for the first-year dose and the 50-year dose commitment per amount of radionuclide inhaled or ingested yearly. The 50-year dose commitment is the total dose received by an organ during the 50-year period following the intake of a radionuclide.

All dose conversion factors (except those for $7 \mathrm{Be}$ ) were taken from Hoenes and Soldat (1977). The 7Be dose conversion factors were taken from values recommended by the International Commission on Radiological Protection (1959).

- Inhalation Dose. Annual average air concentrations of $3 \mathrm{H}, 238 \mathrm{Pu}$, 239-240 Pu, $241 \mathrm{Am}$, and total U, determined by the Environmental Surveillance Group's air monitoring network, are corrected for background by subtracting the average concentrations measured at regional stations. These net concentrations are then multiplied by standard breathing rates for the four age groups to determine total annual intake by inhalation, in $\mathrm{pCi} /$ year, for each radionuciide. Each intake is multiplied by appropriate dose conversion factors to convert intake into first-year-dose and 50-year dose commitments. Organs chosen for dose calculations, bone, liver, total body, kidney, lungs, and gastrointestinal (GI) tract, include those expected to receive the largest dose from the radionuclides being considered. Dose conversion factors for $3 \mathrm{H}$ include an increase of 1.5 over inhalation intake to account for skin absorption.

These procedures for dose calculation conservatively assume that a hypothetical individual is exposed to the measured air concentration continuousiy throughout the year $(8760 \mathrm{~h})$. This assumption is made for the boundary dose, dose to the maximum exposed individual, and dose to the population living within $80 \mathrm{~km}$ of the site.

Organ doses are determined at sampling sites for each radionuclide. A final calculation estimates the total inhalation dose to an organ by summing doses to that organ from each radionuclide.

- Ingestion Dose. Radiochemical results from foodstuff sampling are used to calculate doses to the same organs as considered for the 
inhalation dose. The procedure is similar to that used in the previous section. Corrections for background are made by subtracting the average concentrations from stations not influenced by Laboratory operations. The radionuclide concertration in a particular foodstuff is multiplied by the annual consumption rate (U.S. Nuclear Regulatory Commission 1977) to obtain total annual intake of that radionuclide. Multiplication of the annual intake by the radionuclide's ingestion dose conversion factor for a particular organ gives the estimated dose to the organ. Consumption rates and dose conversion factors used in the calculations are in the Environmental Surveillance Group (1985) report.

Doses are evaluated for ingestion of $3 \mathrm{H}, 90 \mathrm{Sr}, 137 \mathrm{Cs}$, total $\mathrm{U}$, $238 \mathrm{Pu}$, and $239-240 \mathrm{Pu}$ in fruits and vegetables; $3 \mathrm{H}, 7 \mathrm{Be}, 22 \mathrm{Na}, 54 \mathrm{Mn}$, $57 \mathrm{Co}, 83 \mathrm{Rb}, 134 \mathrm{Cs}, 137 \mathrm{Cs}$, and total $\mathrm{U}$ in honey; and $90 \mathrm{Sr}, 137 \mathrm{Cs}$, total $U, 238 \mathrm{Pu}$, and $23 \mathrm{~s}-240 \mathrm{Pu}$ in fish.

- External Radiation Dose. External radiation doses are monitored with the Environmental Surveillance Group's TLD network. Measured exposures are considered whole-body exposures. Background estimates at each site, based on historical data, consideration of possible nonbackground contributions, and if possible, values measured at locations if similar geology and topography, are then subtracted from each measured value. This net dose is assumed to represent the dose from Laboratory activities that an individual would receive if a person were to spend $100 \%$ of his time during an entire year at the monitoring location. These measured values are used where possible to give dose estimates.

At onsite locations at which above background doses were measured, but at which public access is limited, doses based on a more realistic estimate of exposure time are also calculated.

- Population Dose. Calculation of whole-body population dose estimates (in person-rem) is based on measured data to the extent possible. For background radiation, average measured background doses for Los Alamos, White Rock, and regional stations are multiplied by the appropriate population number. Tritium average doses are calculated 
from average measured concentrations in Los Alamos and White Rock above background (as measured by regional stations).

These doses are multiplied by population data incorporating results of the 1980 census, which are summarized in Table 4-1. The population data have been increased from 125,068 to 162,059 persons within $80 \mathrm{~km}$ of the boundary to account for population increases for 1983.

Atmospheric dispersion models are used to calculate an average dose to individuals ?iving in the area in question. The air concentration of the isotope $[\chi /(r, \theta)]$ at a location $(r, \theta)$ due to $i$ ts emission from a particular source is found by using the annual average meteorological dispersion coefficient $\left[{ }_{\chi}(r, \theta) / Q\right]$ [based on Gaussian plume dispersion models (STade 1968)] and the source term Q.

TAELE 4-1. 1983 Population Distribution Within $80 \mathrm{~km}$ of Los Alamos

\begin{tabular}{|c|c|c|c|c|c|c|c|c|c|}
\hline jirection & $\underline{1-2}$ & $2-4$ & $4-8$ & $\underline{8-15}$ & $\underline{15-20}$ & $20-30$ & $30-40$ & $\underline{40-60}$ & $60-80$ \\
\hline$N$ & $\cdots$ & -- & -- & -- & -- & --- & 988 & -- & 320 \\
\hline NNE & --- & --- & --- & 492 & --- & 471 & 1,505 & 1565 & 192 \\
\hline NE & 1 & --- & --- & --- & 276 & 13,147 & 878 & 1003 & 3,409 \\
\hline ENE & -- & --- & --- & 1562 & 1360 & 2,187 & 2,306 & 1033 & 2,062 \\
\hline$E$ & -- & -- & 67 & 20 & 448 & 922 & 560 & -- & 1,401 \\
\hline ESE & -- & --- & --- & -- & --- & 236 & 18,671 & 1039 & 1,438 \\
\hline SE & --- & --- & 6896 & $\cdots$ & --- & --- & 43,094 & 1967 & 6 \\
\hline SSE & $\cdots$ & --- & -- & -- & $\cdots$ & -- & 3,443 & 3500 & 76 \\
\hline$S$ & -- & -- & -- & --- & $-\infty$ & 173 & 334 & 3822 & $-\cdots$ \\
\hline SSW & -- & --- & -- & --- & -- & 444 & 109 & 4476 & 18,195 \\
\hline SW & -- & --- & -- & --- & --- & -- & 171 & 2259 & - \\
\hline WSW & --- & --- & $\cdots$ & $\cdots$ & --- & 171 & 170 & 1383 & 112 \\
\hline$W$ & --- & -- & -- & --- & --- & --- & --- & 89 & 72 \\
\hline WNW & -- & 1464 & 6669 & --- & --- & --- & --- & --- & 1,674 \\
\hline NW & $\cdots$ & 534 & 1756 & -- & -- & --- & -- & 1251 & -- \\
\hline NNW & --- & 590 & 591 & --- & -- & --- & -- & 55 & 54 \\
\hline
\end{tabular}




\subsection{RISK CALCULATIONS}

\subsubsection{Waste Alternatives Study Risk Analyses}

The radiological risk analysis for the waste alterndtives study (Walker et al. 1981) estimated the potential radiation doses to the public and the workers. Calculations were performed for hypothetical operations underlying the implementation of the alternatives.

The alternatives for TRU waste management at LOS Alamos consist of four basic options: (1) leave in place, (2) leave in place with an improved cover, (3) transfer to a new onsite deeper pit, or (4) transfer to an offsite geological repository. In addition to a modification to allow suboptions of onsite or offsite disposal, the basic options are modified to permit processing or no processing of the buried or stored waste. A total of 18 modular options were defined, 9 for buried waste and 9 for stored waste. The modular options were analyzed independently and then combined as required to generate the doses and subsequent radiological impacts for a given al ternative.

Estimated impacts (I) for accidents were presented as the product of population dose $(D)$ in man-rem per event, the event frequency (fe), and time interval $(T)$ as

$$
I\left(\text { man-rem) }=D \frac{(\text { man-rem })}{(\text { events })} \cdot f e \frac{\text { (event) }}{(y r)} \cdot T(y r) .\right.
$$

$D$ is the sum of the doses received by a specific population:

$$
D \frac{(\text { man-rem })}{\text { (events) }} \cdot \sum_{i=1}^{n} d i
$$

where $n$ is the number of people in a specific population receiving a radiation dose, and $d i$ is the radiation dose in rem to a member of that population.

To compare the radiological risk, a Relative Risk Index was computed. The index represented the end point of the analysis and consisted of the cumulative dose equivalents that were estimated for the modular options. 
The index was useful for comparing the relative impact from the various alternatives but was not considered an estimate of absolute risk.

\subsubsection{Hansen and Rodgers Study}

Combining the release mechanisms, source terms, pathways, and dose assessment parameters allows estimation of the dose equivalent for different scenarios. Table 4-2 summarizes the data for the annual dose in the maximum year for several human intrusion scenarios involving the inactive waste Area $C$ at Los Alamos. The data are reported as a range of values for the urbanization and agricultural scenarios of a worker on site exposed to dusts for 70 years. The minimum is for a worker intruding into the wastes while trenching or excavating on the area for 40 hours. The agriculture scenarios are dominated by the home garden grown on the waste area for 70 years.

TABLE 4-2. Critical Organ Dose from Human Intrusion into a Low-Leve? Waste Area Containing TRU Wastes

\begin{tabular}{|c|c|c|c|}
\hline Contact Scenario & $\begin{array}{l}\text { TRU Conc } \\
(\mathrm{nCj} / \mathrm{g}) \\
\end{array}$ & $\begin{array}{l}\text { Short Term }(\mathrm{a}) \\
\text { (100 years) } \\
\text { (mrem/yr) } \\
\end{array}$ & $\begin{array}{r}\text { Lon } \\
(>1000 \\
\text { (mre }\end{array}$ \\
\hline \multicolumn{4}{|l|}{ Urbanization } \\
\hline Average & 0.1 & $11-700$ & $1-28$ \\
\hline Average & 1 & $110-7000$ & $10-280$ \\
\hline \multicolumn{4}{|l|}{ Agricultura? } \\
\hline Average & 0.1 & $0.5-80$ & $2-7$ \\
\hline Average & 1 & $5-800$ & $20-70$ \\
\hline \multicolumn{4}{|c|}{ Deliberate Intruder } \\
\hline Average & 0.1 & 150 & 120 \\
\hline Average & 1 & 1500 & 1200 \\
\hline Contact & 250 & --- & 91,000 \\
\hline
\end{tabular}

(a) Short-term intrusion scenarios are unlikely to occur because administrative ccintrols are expected to restrict access to these areas for at least 100 years. 
The deliberate intruder is assumed to be efther scavenging for materials or digging for archaeological purposes. Two types of exposure are possible in this scenario. The individual contacts all materials and thus is exposed to the average concentrations in the waste trench or encounters a maximum amount of activity in a single item. The values in Table 4-2 reflect the average as $150 \mathrm{mrem} / \mathrm{year}$ from early contact with the wastes to $91 \mathrm{rem} /$ year contacting $250 \mathrm{nCi} \mathrm{TRU} / \mathrm{g}$.

Depending on the amount of dilution. TRU wastes in the range of 10-100 $\mathrm{nCi} / \mathrm{g}$ placed in low-level waste sites could result in doses to intruders exceeding $500 \mathrm{mrem} / \mathrm{year}$. For the analysis, wastes in the L.os Alamos inactive Area $C$ also contained wastes in the range 100-5000 $\mathrm{nCi} / \mathrm{g}$; thus the average is higher than would be the case if these wastes were excluded. Also, of the current wastes from the Los Alamos plutonium facility, $98 \%$ contain less than $10 \mathrm{nCi} \mathrm{TRU} / \mathrm{g}$ and about $1 \%$ contain $10 \mathrm{nCi} \mathrm{TRU} / \mathrm{g}$ to $100 \mathrm{nCi}$ TRU/g.

A possible method to avoid the question of whether doses to unintentional human intruders should be decisive in the regulatory process would be to eliminate or limit the pathways. By utflizing the bottoms of existing waste trenches or using special trenches for wastes containing 10-100 $\mathrm{nCl} / \mathrm{g}$, one can eliminate plant and animal intrusion, agricultural scenarios, and limit exposures from earthmoving intrusion. Accordingly, all wastes contaminated with TRU materials in the range of $10-100 \mathrm{nCi} / \mathrm{g}$ are required to be buried at least $5 \mathrm{~m}$ below the "spill point" of the pit, and the pit must be at least $25 \mathrm{~m}$ from the canyon rim. This institutes, in effect, a form of "greater confinement disposal" for these wastes.

\subsubsection{Pantex EIS and BEIR III Risk Analyses}

For the Environmental Impact Statement (EIS) for the DOE Pantex Plant near Amaril1o, Texas, the human food chains at the Hanford Site, Iowa Army Ammunition Plant, and Pantex were studied, sampled, and later simulated by using the Los Alamos dose assessment model BIOTRAN (US DOE 1982). Field data were compared with the simulation output throughout the analyses for potential accidental releases of plutonium and for natural and depleted uranium in soils.

Figure 4.1 shows the calculation flow used to calculate doses for the Pantex EIS supplementary documents (Wenzel and Gallegos 1982, Wenzel et 


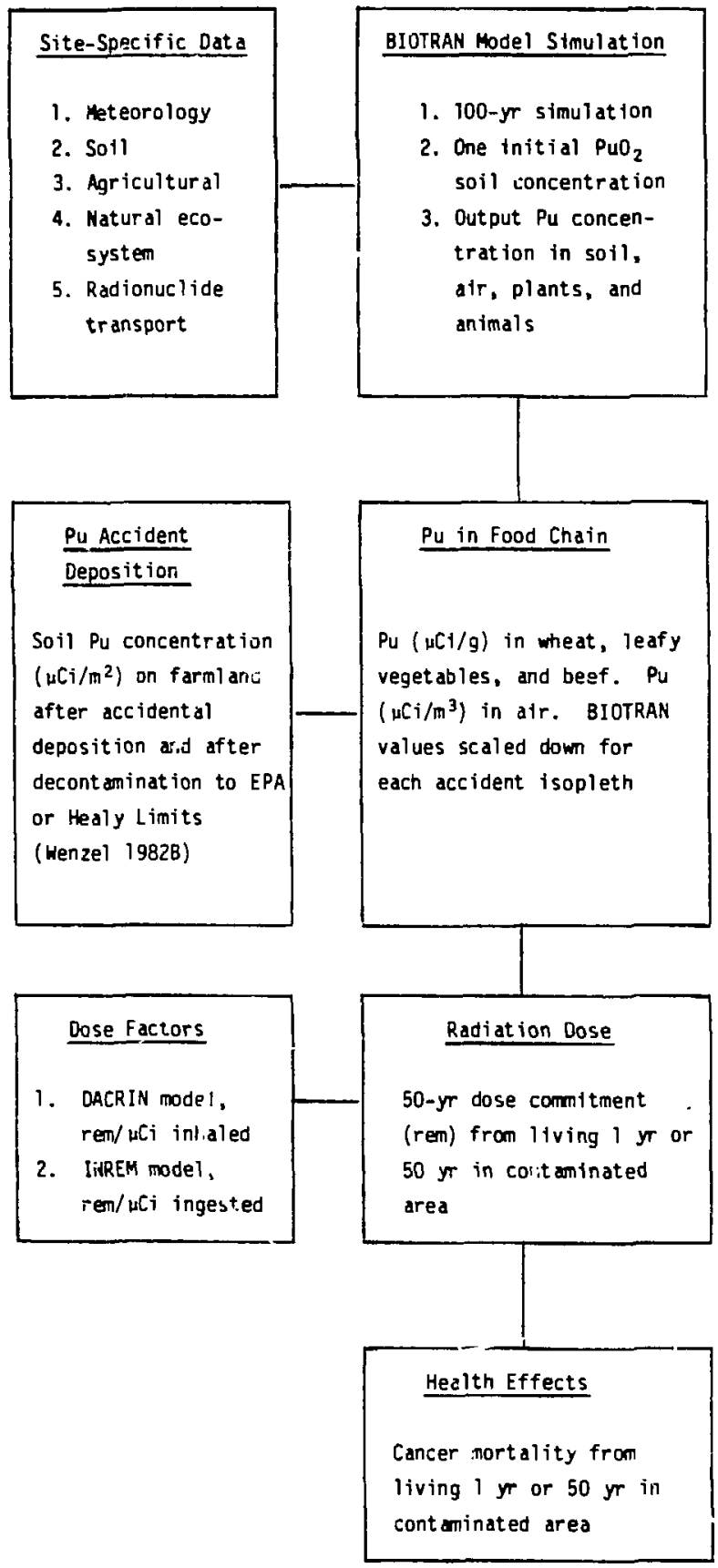

FIGURE 4.1. Calculation Flow for Long-Term Health Effects. 
al. 1982a, Wenzel et al. 1982b, and Buh1 1982). The results of the field and simulation studies were used to calculate radiation dose to the population surrounding these sites from postulated accidents and ambient radiological conditions for a variety of scenarios over the next 100 years. These analytical calculations and field data were then used to validate portions of the risk assussment models (Gallegos and Wenzel 1984, Wenzel and Gallegos 1985, Buhl and Hansen 1984). The Pantex EIS studies gave the necessary data to later develop the human physiology and radionuclide metabolism model HUMTRN and the population risk models REPCAL and EFFECTS as part of the overall risk assessment model capabilities at Los Alamos. The risk assessment models calculate the impact to a population from radiation exposure based on the BEIR III (1980) report. The EFFECTS population risk model is based on the earlier work by Buhl and Hansen (1984) and developed population dynamics (mortality and natality) for use with BIOTRAN. This allowed impact predictions to be done over hundreds or thousands of simulated years with sufficient resolution to determine the particular age and sex groups at highest risk in the population exposed. These environmental, dose, and risk assessment models allow dynamic computer simulations for the entire scenario from release, distribution, transport, uptake, intake, dose, and population risk. 


\section{REFERENCES}

BEIR III. 1980. The Effects on Population of Exposure to Low Leve1s of Radiation: 1980. National Research Council, National Academy of Science, Committee on Biological Effects of Ionizing Radiation, National Academy Press, Washington, DC.

Buh1, T. 1982. Supplementary Documentation for an Environmental Impact Statement Regarding the Pantex Plant: Radiation Monitoring and Radiological Assessment of Routine Releases. LA-9445-PNiX-C, Los Alamos National Laboratory, Los Alamos, New Mexico.

Buhl, T., and W. R. Hansen. 1984. Estimating the Risks of Cancer Mortality and Genetic Effects ResuTting from Exposure to Low Levels of Ionizing Radiation. LA-9895-MS, Los Alamos National Laboratory, LoS Alamos, New Mexico.

Environmental Surveillance Group. 1983. Environmental Surveillance at Los Alamos During 1982. LA-9762-ENV, Los Alamos National Laboratory, Los Alamos, New Mexico.

Environmental Surveillance Group. 1985. Environmental Surveillance at Los Alamos During 1982. LA-10421-ENV, Los ATamos National Laboratory, Los Alamos, New Mexico.

Gallegos, A. F. and W. J. Wenze1. 1984. HUMTRN: Documentation and Verification for an ICRP-Based Age- and Sex-Specific Human Simulation Model for Radionuclide Dose Assessment. LA-9994-MS, Los ATamos National Laboratory, Los Alamos, New Mexico.

Hoenes, G. R., and J. K. Soldat. 1977. Age-Specific Radiation Dose Commitment Factors for a One-Year Chronic Intake. NUREG-0172, U.S. Nuclear Regulatory Commission, Washington, DC.

International Commission on Radiological Protection (ICRP). 1959. Report of Committee II on Permissible Dose for Internal Radiation. ICPP Publication 2, Pergamon Press, New York.

International Commission on Radiological Protection (ICRP). 1974. Report of the Task Group on Reference Man. International Commission on Radiological Protection Publication 23, Pergamon Press, New York.

Slade, D. H., Ed. 1968. Meteorology and Atomic Energy 1967. TID-24190, U.S. Atomic Energy Commission, Washington, DC.

U.S. Department of Energy. 1981. A Guide for Environmental Radiological Surveillance at U.S. Department of Energy Installations. DOETEP-0023, U.S. Department of Energy, Washington, DC. 
U.S. Department of Energy. 1982. Draft Environmnetal Impact Statement: Pantex Plant Site. DOE/EIS-0098-D, U.S. Department of Energy, Washington, DC.

U.S. Nuclear Regulatory Commission. 1977. Calculatioii of Annual Doses to Man from Routine Releases of Reactor Effluents for the Purpose of Evaluating Compliance with 10 CFR Part 50, Appendix I. U.S. Nuclear Regulatory Commission Regulatory Guide 1.109.

Walker, L. J., et al. 1981. Alternative Transuranic Waste Management Strategies at Los Alamos Naccional Laboratory. LA-8982-MS, Los A1amos National Laboratory, Los Atamos, New Mexico.

Wenzel, W. J., and A. F. Gallegos. 1982. Supplementary Doc!mentation for an Environmental Impact Statement Regarding the Pantex Pla it: Long-Term Radiological Risk Assessment for Postulated Accidents. LA-9445-PNTX-D, Los Alamos National Laboratory, Los Alamos, New Mexico.

Wenzel, W. J., et al. i982a. Supplementary Documentation for an Environmental Impact Statement Regarding the Pantex Plant: Agricultura Food Chain Radiological Assessment. LA-9445-PNTX-M, Los Alamos National Laboratory, Los Alamos, New Mexico.

Henze1, 1. J., et al. 1982b. "The Texas Panhandle Soil-Crop-Beef Food Chain for Uranium: A Dynamic Model Validated by Experimental Data." CONF-821215, 4th DOE Environmental Protection Information Meeting, Denver, Colorado.

Henzel, W. J., and A. F. Gallegos. 1985. EFFECTS: Documentation and Verification for a BEIR III Cancer Risk Model Based on Age, Sex, and Population Dynamics. LA-10371-MS, Los A7amos Nationa7 Laboratory, Los ATamos, New Mexico. 


\subsection{MODEL DOCUMENTATION, VERIFICATION, AND VALIDATION}

\subsection{GROUND WATER TRANSPORT MODELS}

\subsubsection{Hansen and Rodgers Model}

Precise modeling of subsurface hydrology at LOS Alamos would require some combination of fracture and porous flow models, for both the unsaturated and saturated zones. Although some carabilities for this modeling exist (Travis 1984), most apply only to saturated conditions. And even then, the problem remains of knowing the density, spacing, and orientation of fractures and joints in the rock along the flow path. Similar uncertainties pertain to two other crucial aspects of hydrologic pathway analysis: leaching of solid waste forms and sorption/desorption reactions between transuranic radionuclides and geologic media. Although progress has been made toward understanding and modeling these processes for saturated conditions, the uncertainties are larger for unsaturated and fracture flow conditions.

To roughiy scope the potential ground water release and transport processes at Los Alamos, the generalized modeling approach, based on techniques developed by Aikens et a1. (1979) to assess ground water migration consequences, was applied to the Los Alamos case by Hansen and Rodgers (1983) in the following discussion.

An illustration of the generalized geohydrologic setting at Los Alamos is shown in Figure 5.1. A disposal volume is assumed to he located in the unsaturated zone in a mesa bounded on two sides by ephemeral streams and one side by the Rio Grande River. The cavity is assumed to be situated at sufficient depth and with sufficient horizontal offset to mitigate erosion effects. A further assumption is that the local wells that could be affected by any radionuclides released from the wastes are located in the canyon bottoms rather than on the mesa tops.

The geometry of the well case is shown in Figure 5.2. Note that the limits for streamlines intercepting the well impose constraints on the distance a well can be located from the centerine of contaminant flow before contaminated water enters a well. If the cavity is considerably offset from the mesa edge (Figure 5.2), no contaminants would likely enter 


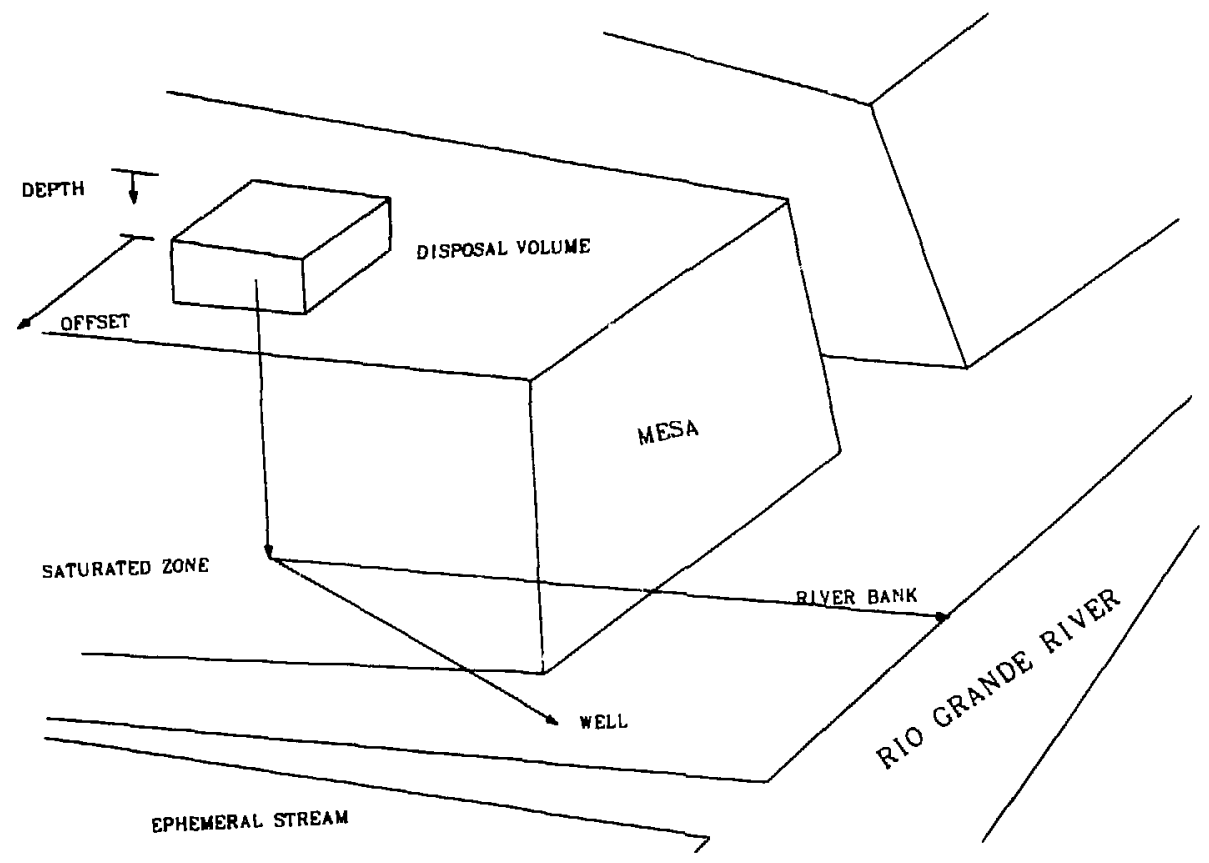

FIGURE 5.1. Generalized Los Alamos Geohydrology Setting.

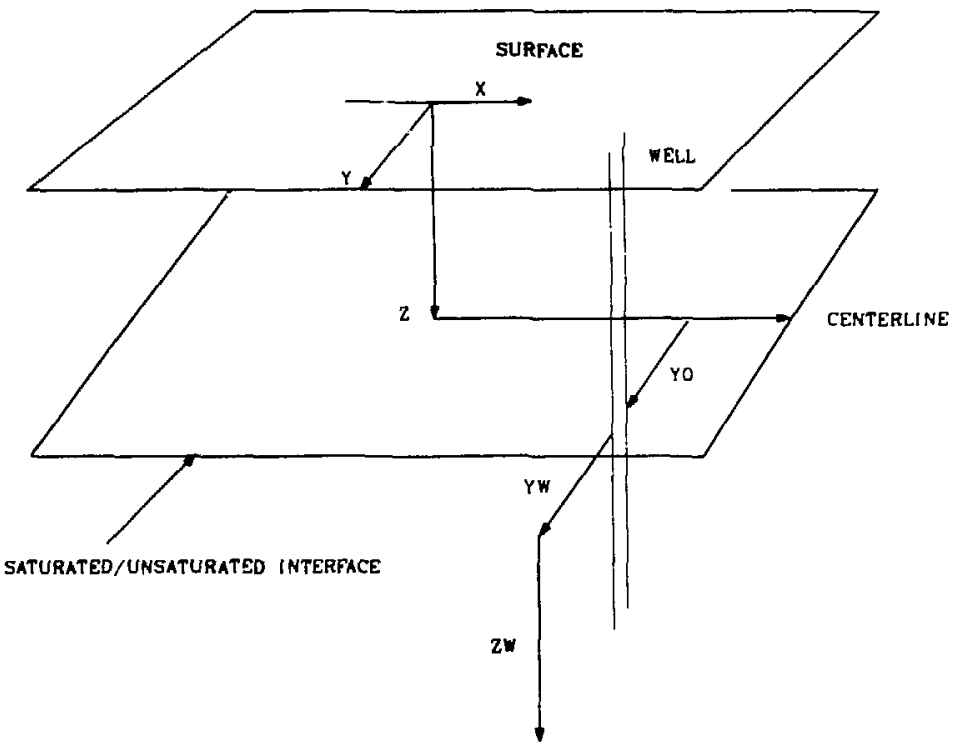

FIGUKE 5.2. Geometry of Well Parameters. 
the wel1 (river bank case), unless the local underground flow paths deviate from the surface contours (well case). The relationship between the halfwidth of the well discharge surface $y$ and pumping rate $Q$ as water volume per day is given by

$$
Q=2 n \cdot v \cdot y w \cdot z w
$$

where $n=$ porosity (unitless)

$v=$ saturated flow velocity in $\mathrm{m} / \mathrm{d}$

$\mathrm{zW}=$ well depth in saturated zone in $\mathrm{m}$ $y w=$ half-width of discharge surface in $m$.

For a porosity of $0.43, v=0.3 \mathrm{~m} / \mathrm{d}(1 \mathrm{ft} / \mathrm{d}), z w=7 \mathrm{~m}(23 \mathrm{ft})$ and $Q=28$ $\mathrm{m}^{3} / \mathrm{d}$; the magnitude of $y w$ is about $: .5 \mathrm{~m}(30 \mathrm{ft})$. Hence, if the disposa 1 cavity were offset $40 \mathrm{~m}(130 \mathrm{ft})$, there wouid have to be a relatively large deviation in flow direction to create a well water release. However, for the purpose of the analysis, it is assumed that water is released via discharge to the river through a river bank discharge surface.

The computational procedure and the many assumptions associated are described in detail by Aiken et al. (1979) and will only be briefly summarized here. The saturated media are assumed to be homogeneous and isotopic with unidirectional hydraulic velocity. A downward flux of radionuclides exists through the bottom of the cavity constituting a source term flux $\mathrm{J}_{0}(x, y, t)$ with units $\mathrm{Ci} / \mathrm{day}$. This source results in total flux of radionuclides through a "discharge surface" (well or river bank) of $J(x, t)$ $\mathrm{Ci} /$ day. The problem to be solved, then, is the relation between the source flux $J_{0}(x, y, t)$ and the discharge rate $J(x, t)$. The problem can be solved analytically, given a number of assumptions. The generalized relation is given by

$$
J(x, t)=r_{j} \cdot r_{s} \cdot r_{t} J_{0}(x, y, t)
$$


where $r_{j}=$ reduction factor due to sorption of radionuclides in the porous medium. This measure of the fraction of radionuclides in the porous medium coniributes to the flux at the discharge 1ccation.

$$
\begin{aligned}
r_{s}= & \text { reduction factor due to dispersion and spatial configuration } \\
& \text { of the problem. } \\
r_{t}= & \text { reduction factor due to the combined effects of sorption, } \\
& \text { dispersion, and radioactive decay. The expression } r_{t} \text { cannot } \\
& \text { be evaluated exactly analytically, but it can be bounded in } \\
& \text { the sense that its maximum value is less than the product of } \\
& \text { two analytic expressions } r_{0} \text { and } F_{T} \text {. }
\end{aligned}
$$

The source term is difficult to estimate for this problen because the soil moisture content stays relatively constant at depths greater than several meters. But the usual approach to the analysis of the release of radioactivity from buried wastes is to assume that for at least part of the year, the soil/waste mixture is wetted to a point where the results of leach tests or data from leachate collected at shallow land burial sites are applicable in determining release rates. This approach has been interpreted to assume that during part of the year, the scil/waste mixture approaches field capacity (about $20 \%$ moisture content) as a result of tine annual infiltration moving through the waste. If we follow this approach as a means of bounding the problem, then the Los Alamos site annual infiltrating flux of $120 \mathrm{~mm} /$ year of water (Wheeler, Smith and Gallegos 1977 ) is equivalent (if concentrated in a slug) to a band in che soil/waste mix wetted up to field capacity of $20 \%$, which would be $0.6 \mathrm{~m}$ thick. This wetted band moves through a given plane in the waste in a characteristic contact time, which is a function of soil/waste texture and moisture content. Contact time will be taken to corre:dond to the waste/water contact time in the typical leach test methodologj. Btyond contact time, the factors determining release of alpha activity from the waste to infiltrating water are related to the physical and chemical characteristics of the waste and the matrix in which it is embedded. 
The source terms arising from solidified and unsolidified wastes have been combined to create a single source for release and pathway analysis (Jackson and Inch 1980, Dunning et a1. 1981, Healy and Rodgers 1979). With the exception of $239 \mathrm{Pu}$ and the uranium isotopes, the majority of the source derives from solidified waste due to the large inventory in that category. These source terms are shown in Table 5-1.

Two principal concerns are addressed in the following discussion. One is whether ground water migration is a possible release mechanism at Los Alamos that would tend to offset the higher concentrations of alpha emitters, which could be permitted in greater depth disposal based on erosion analyses. The other concern is to determine what parameters in the containment system at Los Alamos are most sensitive with respect to release, transport, and dose to man via the ground water pathway.

The ground water transport conditions assumed for the disposal of alpha emitters at Los Alamos are summarized in Table 5-2. Briefly, it is assumed that the disposal capacity is deep enough and that for the period of interest $\left(\cong 10^{9}\right.$ years), the source is affected only by radioactive decay

TABLE 5-1. Combined Solidified and Unsolidified Source Terms for Los Alamos TRU Waste

\begin{tabular}{ll} 
Nuclide & Source $(\mathrm{Ci} / \mathrm{yr})$ \\
\cline { 2 - 2 } $238 \mathrm{Pu}$ & $2.2 \times 10^{-5}$ \\
$239 \mathrm{Pu}$ & $7.6 \times 10^{-5}$ \\
$240 \mathrm{Pu}$ & $1.6 \times 10^{-5}$ \\
$241 \mathrm{Pu}$ & $3.0 \times 10^{-5}$ \\
$242 \mathrm{Pu}$ & $1.6 \times 10^{-8}$ \\
$241 \mathrm{Am}$ & 3.8 \\
$233 \mathrm{U}$ & $1.3 \times 10^{-6}$ \\
$234 \mathrm{U}$ & $2.4 \times 10^{-6}$ \\
$235 \mathrm{U}$ & $3.5 \times 10^{-9}$ \\
$236 \mathrm{U}$ & $2.4 \times 10^{-6}$ \\
$238 \mathrm{U}$ & $1.8 \times 10^{-6}$
\end{tabular}


TABLE 5-2. Ground Water Transport Conditions at LoS Alamos for Modeling

I. Unsaturated Zone Conditions

Depth to Aquifer:

Seepage velocity:

Moisture flux:

Dispersivity:
$213 \mathrm{~m}(700 \mathrm{ft})$

$1.52 \times 10^{-7} \mathrm{~m} / \mathrm{d}\left(5 \times 10^{-7} \mathrm{ft} / \mathrm{d}\right)$

$120 \mathrm{~mm} /$ year

$2.01 \times 10^{-4} \mathrm{~m}\left(6.6 \times 10^{-4} \mathrm{ft}\right)$

Retardation coefficients:

$\mathrm{Pu}=150, \mathrm{Am}=1000, \mathrm{Th}=150, \mathrm{Ac}=150, \mathrm{~Pa}=150, \mathrm{Ra}=150, \mathrm{U}=2.5$

II. Saturated Zone Conditions

Distarice to wel? discharge:

$6.4 \times 10^{3} \mathrm{~m}\left(2.1 \times 10^{4} \mathrm{ft}\right)$ water

Velocity:

$0.3 \mathrm{~m} / \mathrm{d}(1 \mathrm{ft} / \mathrm{d})$

Dispersivity:

$3.05 \times 10^{-3}(0.01 \mathrm{ft})$

Well pumping rate:

$28.3 \mathrm{~m}^{3} /$ year $\left(1000 \mathrm{ft}^{3} /\right.$ year $)$

Well depth:

$21.3 \mathrm{~m}(70 \mathrm{ft})$

Porosity:

0.45

Retardation coefficients:

$\mathrm{Pu}=300, \mathrm{Am}=2000, \mathrm{Th}=300, \mathrm{Ac}=300, \mathrm{~Pa}=300, \mathrm{Ra}=300, \mathrm{U}=5$

and leaching, not by erosion. The cavity is assumed to be located entirely in the unsaturated zone. Flow velocity, dispersivity, retardation, and the like are assumed to have their respective different values in unsaturated and saturated zones, but otherwise are homogeneous and isotropic.

These parameters are based on measured geohydrologic conditions reported by Abeele, Wheeler and Burton (1981) and on measurements of radionuclide transport and retardation in tuff reported by Vine et al. (1981) for Nevada Test Site (NTS) materials, but may be relevant to Los Alamos tuff. They are not worst-case estimates. In particular, the decision to use unsaturated-zone retardation factors one-half as large as saturated zone factors is based on the observation of 2 to 5 times smaller factors in column measurements compared with batch test (Vine et al. 1981) measurements on NTS tuff. Also, the low seepage velocity in the unsaturated zone 
is based on measured hydraulic conductivity in tuff at about $10 \%$ moisture content (Abeele, Wheeler and Burton 1981). The hydraulic conductivity represents an approximation of the actual complex flow through the jointed and layered tuff on the Los Alamos mesas. These estimates are reasonable approximations to actual conditions at Los Alamos.

The travel distance and retardation coefficient assumptions in saturated and unsaturated media specified in Table 5-2 are the major ground water transport conditions. Contaminant velocity equals the water velocity divided by the retardation coefficient of the contaminant; therefore, for most of the actinides, travel times through the unsaturated zone at Los Alamos are about $108-10^{9}$ years. This is more than enough time to permit complete decay of the plutoniums, including 242Pu. However, for many of the daughters of plutonium, this time frame serves only to permit complete ingrowth of uranium, thorium, and neptunium.

Accordingly, even without any sophisticated modeling, both the longlived uranium and thorium daughters of the plutonium and the long-lived uraniums $(238 \mathrm{U}, 235 \mathrm{U})$, if buried along with TRU wastes, would be discharged into the aquifer eventually (albeit at exceedingly long times past disposall. And the same will be true of the daughters of these actinides, which include alpha-emitting protactinium, actinium, and radium isotopes. Detailed modeling, with the use of the simplified approach to predict maximum discharges of decay chain radionuclides, bears out this expectation. The results of modeling several of the transuranic decay chains are summarized in Table 5-3. Clearly, large well water concentrations and correspondingly large critical organ doses could result at maximum discharge (i.e., at long times past disposal). The columns labeled "without uranium" are results of simulations in which the Los Alamos uranium source terms have been removed to test for which component of the TRU waste is responsible for these large predicted releases. The uranium precursors support large releases, with the important exception of the $241 \mathrm{Pu}$ chain. In this case, the $241 \mathrm{Am}$ parent of $237 \mathrm{~Np}$ creates large releases, although the parent completely decays in the process. These results raise the question of whether the value of some of the critical parameters determining release of these alpha emitters could readily change such that releases would be limited compared with the central estimates of Table 5-3. For example, the percolation estimate of $120 \mathrm{~mm} /$ year is based 
TABLE 5-3. Surmary Results of Modeling Transuranic Decay Chain

Transport in the Los Alamos Geohydrologic Setting for

Combined Solidified and Unsolidified Alpha Waste

Maximum Well Water

Concentration from A11

Chain

$\frac{\text { Member }}{239 \mathrm{Pu}^{(a)}}$

$235 u^{(a)}$

$231 \mathrm{Pu}$

$227 \mathrm{AC}$

$240 \mathrm{Pu}^{(\mathrm{a})}$

$236 \mathrm{U}^{(\mathrm{a})}$

232 Th

$228 \mathrm{Ra}$

$241 \mathrm{Pu}(\mathrm{a})$

$24 \mathrm{iAm}$ (a)

$237 \mathrm{~Np}$

$233 U^{(a)}$

$229 \mathrm{Th}$

$242 p_{u}^{(a)}$

$238 \mathrm{u}^{(\mathrm{a})}$

$234 U^{(a)}$

230 Th

$226 \mathrm{Ra}$
Sources $(\mathrm{pCj} / \mathrm{L})$

\begin{tabular}{cc} 
With U & Without U \\
\hline 0.0 & 0.0 \\
0.1 & 0.04
\end{tabular}

1000

0.01

0.0

0.3

3500

0.01

0.0

0.0

2400

600

10

0.0

3.2

$2.2 \times 10^{6}$

0.5

0.56
Annual Dose to Bone via Most Limiting Pathway

(rem/year)

$\frac{\text { With U }}{0.0} \quad \frac{\text { Without U }}{0.0}$

1.9

$<10^{-3}$

228

$<10^{-3}$

$>10^{-3}$

$>10^{-3}$

0.0

0.0

0.6

$<10^{-3}$

1000

$<10^{-3}$

$<10^{-3}$

$<10^{-3}$

0.0

0.0

0.0

0.0

333

333

13

13

0.5

0.5

0.0

0.0

0.06

$<10^{-3}$

$5 \times 10^{4}$

$<10^{-3}$

0.001

$<10^{-3}$

0.001

$<10^{-3}$

(a) Designates parent with source strength given in Table 5-1.

on the current meteorology record with a mean annual precipitation of 457 $\mathrm{mm}$, whereas tree-ring measurements related to precipitation suggest that over a period of centuries, Los Alamos precipitation may be as low as $58 \mathrm{~mm}$ or as large as $768 \mathrm{~mm}$ (Abeele, Wheeler and Burton 1981). If the largest portion of this change occurs during the summer months when potential evapotranspiration is high, the effect on seepage volume would be 
minimized, but if it occurs in the winter or is associated with overall lower temperatures, the effect could be amplified.

To estimate a reasonable range in magnitude of this critical parameter is not simple. However, it is possible to test the effect of changes in this and other critical parameters such as depth of burial, retardation coefficient, and seepage velocity in a sensitivity analysis.

If we consider first the depth of burial or, rather, the distance between the disposal cavity in the unsaturated zone and the top of the aquifer, varying this distance over the full extent of the mesa thickness (from $225 \mathrm{~m}$ to within about $15 \mathrm{~m}$ of the underlying aquifer) has very little effect on the magnitude of the predicted well water concentration of very long-lived alpha emitters. The plutonium discharges are essentially zero over this range, and the neptunium, uranium, thorium, protactinium discharges are little changed over Table 5-2 values. The time to discharge increases with increasing thickness, but not enough to eliminate the long-lived radionuclides by decay.

Considering changes in the seepage velocity in the unsaturated zone, Figure 5.3 shows that for a range of two orders of magnitude on either side of current estimated unsaturated zone seepage velocity, the concentration of members of the $242 \mathrm{Pu}$ decay chain are little affected. This result is typical of the predicted response of long-lived members of the several TRU decay chains. Unquestionably, the largest effect of change in seepage velocity would be the cutoff of nearly all releases under conditions of long-term drought. The previously mentioned difficulty of estimating seepage volume from estimated annual precipitation extremes applies here as well. Apparently, because the Los Alamos semiarid, high-altitude setting tends toward conditions in which evapotranspiration exceeds precipitation input, any residual uncertainty in assigning the magnitude of the seepage velocity is not likely to contribute substantially to uncertainty in release.

Finally, considering the effects of uncertainty in the retardation coefficients of individual radionuclides under changing site conditions, Hanson and Rodgers (1983) noted the additional complexity that some of the actinides have quite stable retardation coefficients with respect to changes in geochemistry. 0ther actinides are apt to exhibit large changes in retardation with such changes in site conditions. The very long-lived 


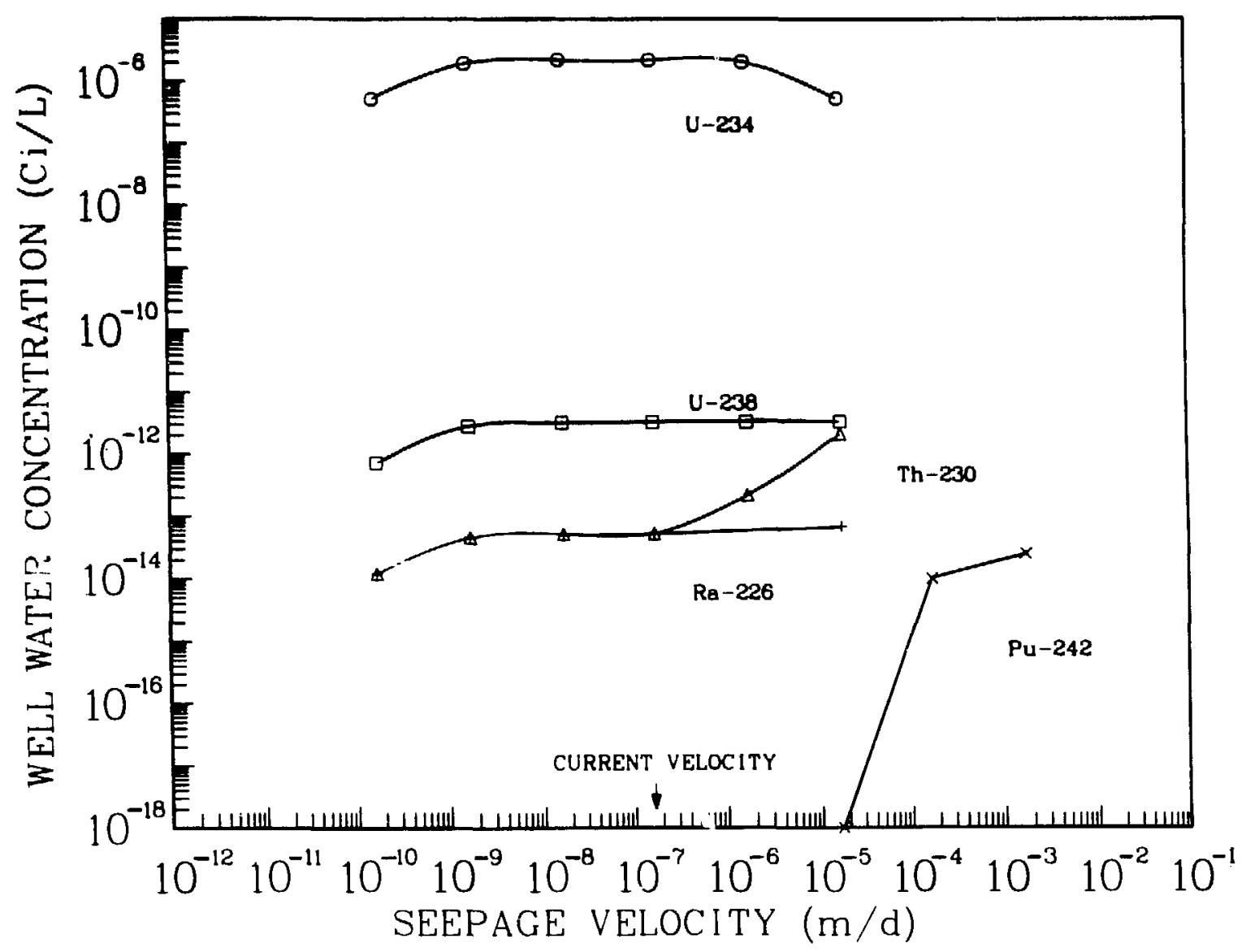

FIGURE 5.3. Effect of Well Water Concentrations of Changes in Seepage Velocity.

uranium isotopes are such a persistent source that, for example, al though the retardation of $238 \mathrm{U}$ is varied from 2.5 to 3000 , the effect on well water concentration of this isotope and its decay products is only a reduction somewhat less than one order of magnitude ( 3 to $0.5 \mathrm{pCi} / \mathrm{L}$ ). Again, the most pronounced effect is on travel time to release. Others, such as $239 \mathrm{Pu}$ and $241 \mathrm{Am}$, have a short-enough half-life that, even for a retardation of one, no release of them is predicted to occur. Perhaps the most sensitive response to change in retardation is observed with $237 \mathrm{~Np}$. A change in retardation from 2.5 to 52 reduces the predicted well water concentration frim $2 \times 10^{-9} \mathrm{Ci} / \mathrm{L}$ to essentially zero $\left(10^{-25} \mathrm{pCi} / \mathrm{L}\right)$. A similar, not so dramatic, response is observed with $236 \mathrm{U}$ (in the $24.0 \mathrm{Pu}$ chain). A change 
in retardation from 3.5 to 57 (al1 other factors constant) results in a predicted drop of well water concentration from $3 \times 10^{-11}$ to $5 \times 10^{-14}$ $\mathrm{Ci} / \mathrm{L}$. Apparently, these radionuclide half-lives are such that significant loss by decay occurs within the 227-m unsaturated zone if their retardation constant is even moderately larger than suggested by measurements.

These preliminary findings indicate that, although uncertainties in the magnitude of critical parameters governing transport over the large times to discharge cou'id serve to vary the level of expectation that some migrating decay chains of transuranics will eventually reach accessible discharge locations (i.e., 240Pu, 241Pu), other chains almost invariably will result in discharge (i.e., 239pu, 242Pu). This does not mean that the magnitude and duration of discharge is unaffected by increased travel times" only that the expected maximum discharge could be large enough to result in significant doses. The approach taken in the modeling at this point is too simplified to be more specific about the reliease episode. These results suggest that a more detailed simulation approach, such as that of Lester, Jansen and Burkholder (1979), could be profitably applied to this case.

\subsubsection{TRACR3D Mode 1}

The TRACR3D computer code was developed at Los Alamos to simulate transport of solutes through unsaturated as well as saturated soils and rock. The model computes water and/or air fîow under soil moisture conditions ranging from fully saturated to completely dry. Material properties can vary spatially. A variety of boundary and source/sink conditions is possible. The code also simulates transport of sorbable species. Transport mechanisms in saturated and unsaturated media include equilibrium or kinetic energy. Decay chains and leaching sources are allowed. The TRACR3D model has beer used to study migration of species from underground nuclear explosions, high-level underground waste storage, and low-level radioactive shallow waste burial.

Any mathematical model, to be useful, must be verified (compared with analytic solutions) and validated (compared with experimental data).

Laboratory experiments are usually well controlled but do not allow all length and time scales to be tested. Field experiments allow a wider 
range of length and time scales but are frequently subject to uncertainty regarding the spatial distribution of material properties. The Los Alamos caisson experiments allow testing of larger length and time scales than experiments allow but without the lincertainties of large-scale field experiments.

In 1984, validation of TRACR3D code in a one-dimensional form was obtained for flow of soil water in three experiments (Perkins and Travis 1985). In the first experiment, a pulse of water entered a crushed-tuff soil and initially moved under conditions of saturated flow, quickly followed by unsaturated flow. In the second experiment, steady-state unsaturated flow took place. In the final experinent, two slugs of water entered crushed tuff under field conditions.

The first field experiment was performed in a 3-m-diameter, 6-m-deep caisson, which was filled with crushed tuff (Abeele 1984 and DePoorter et a1. 1982). Tensiometers and access tubes for neutron moisture gauge determinations of volumetric water content were emplaced at 75-cm increments within the caisson and measurements collected frequently for $C$ weeks. A 13-cm pulse of water was added to the surface of the caisson, and the top of the caisson was sealed to prevent evaporation of water. Figure 5.4 shows the resulting changes in soil water content with time.

The change in volumetric moisture pulse decreased in amplitude rather quickly as it moved downward, and below $400 \mathrm{~cm}$, no change in volumetric moisture could be detected experimentally (Figure 5.4). The data indicate that, although movement of soil water could not be detected below approximately $400 \mathrm{~cm}$ at any time during the experiment, drainage from the caisson would require that soil water was moving below this horizon with flux-in equal to flux-out in those regions in which no change in soll moisture was detected.

The data also indicate that the introduction of water at the surface was felt very quickly at the bottom of the caisson, with drainage increasing to day 12-13, after which the drainage rate remaiiled the same through day 22, when the experiment was terminated.

The code model (Perkins and Travis 1985) predicts that for the initial given conditions once a $13-\mathrm{cm}$ slug of water is added, saturated flow will be near the soil surface just after ponding. At a few centimeters below the surface, this flow becomes unsaturated, with the volumetric moisture 


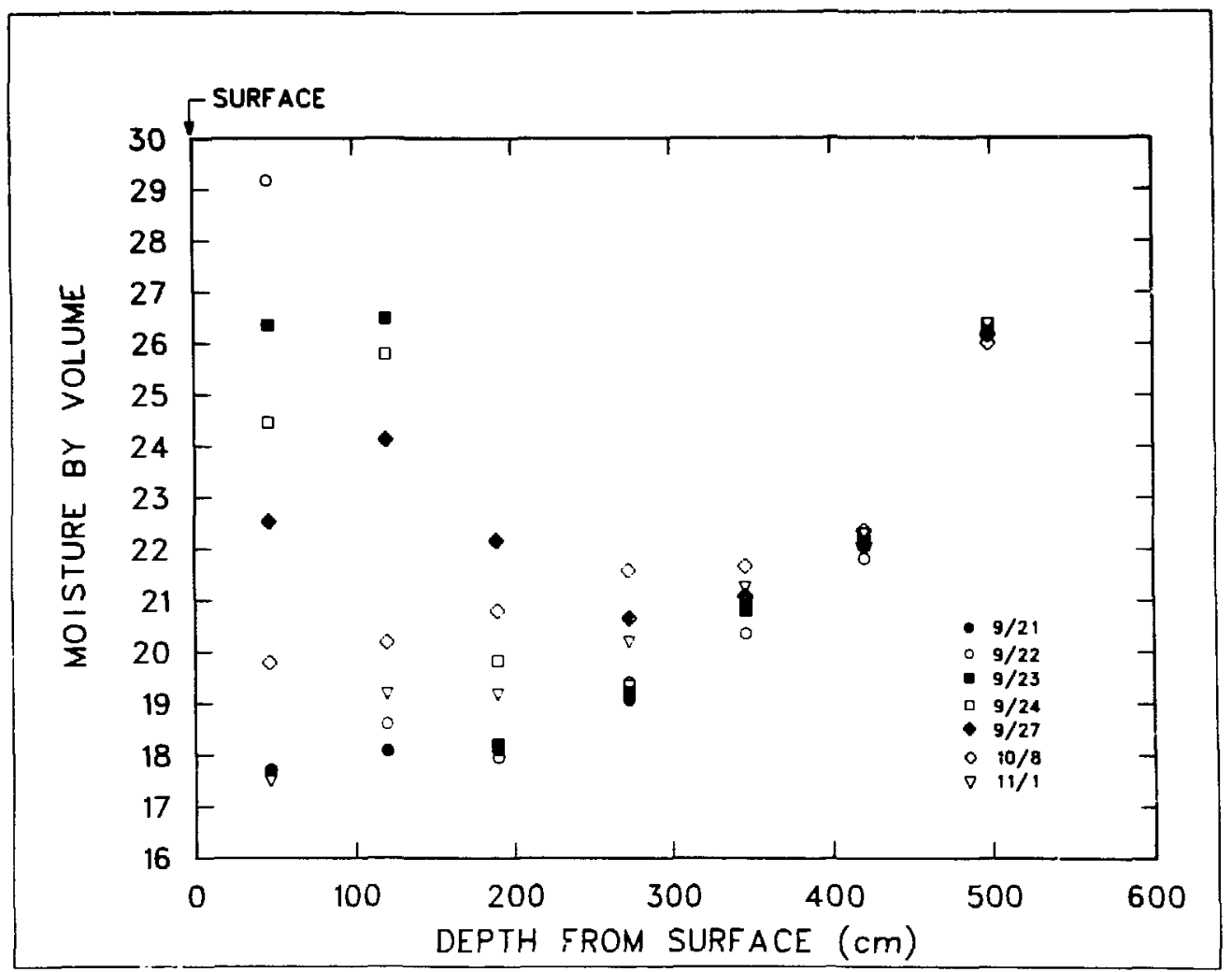

FIGURE :.4. Water Pulse Moisture as a Function of Depth and Time.

pulse having a small width at $3.2 \mathrm{~h}$. Very quickly all flow is unsaturated and the pulse width continues to broaden, with a decrease in amplitude as the pulse moves downward. By $400 \mathrm{~cm}$, the effect of the pulse becomes very small in terms of changes in volumetric moisture and, below this, the changes are too smail to detect experimentally. At the bottom of the caisson at the tuff/sand and sand/gravel interfaces, moisture levels at each interface are predicted to increase until approximately day 12.

Very close agreement was observed between the TRACR3D code predictions and the experimental data from the field experiment. When both types of data were compared in terms of saturation ratios, they generally differed by a saturation ratio of only 0.02 (Perkins and Travis 1985).

A second caisson was filled and instrumented similar to the caisson in the first experiment. By using a drip irrigation system, water was uniformly applied across the surface of the caisson at a uniform flow rate 
of $200 \mathrm{mi} / \mathrm{min}$ until equilibrium conditions (same flow in and out) were achieved.

The experimental and the code data showed the crushed tuff in the caisson to have saturation ratios ranging from 0.84 to 0.88 , again showing close agreement as in the first experiment.

The purpose of the final experiment was to compare the TRACR3D code simulation with a field experiment in which moisture levels were initially low and data were taken over almost a year. The field experiment was much closer to actual conditions in a burial site because the material properties of the fill had not been determined (as they were in the caisson experiments). In the field installation excasated into Bandelier tuff, 220 $\mathrm{cm}$ of crushed tuff is overlain by $61-\mathrm{cm}$ of 7.6 - to $17.8-\mathrm{cm}-$ diameter cobble, covered by $30 \mathrm{~cm}$ of 1.9- to 2.5-cm-diameter gravel and, finally, at the surface, covered with $30 \mathrm{~cm}$ of topsoil. After emplacement of the experiment, soil moisture as a function of depth was measured at regular intervals for almost a year (Figure 5.5 ?.

$A$ rain gauge at a nearby station indicated that between December 1 , 1982, and February 23, 1983, approximately $9 \mathrm{~cm}$ of moisture as snow fell at the site. During February, the snow melted. In March, approximately 2.5 ch of additional precipitation occurred. The field moisture data indicate the fate of this winter precipitation. Because of low evaporation in the winter and the flat terrain, most of the precipitation infiltrated into the $30 \mathrm{~cm}$ of topsoil. Because of the soil/gravel interface, buildup of soil water occurred in the topsoil until the potential at the interfaces became the same, and a slug of moisture entered the cobble and moved downward into the underlying srushed tuff fill. The data indicate that at the top of the crushed tuff, two slugs of water entered, creating a physical situation in the field similar to the experiment run earlier in the first caisson.

Integration of the "before" and "after" moisture in the crushed tuff indicates that approximately $8 \mathrm{~cm}$ of water entered the tuff in a fairly short interval before February 23, 1983, and another 2-cm slug of water just before March 21, 1983. Significant evaporation from the crushed tuff is prevented by the upper cobble/gravel cover. During the rest of the year, despite additional precipitation, moisture losses from evapotranspiration processes prevented buildup and "breakthrough" at the topsoil/gravel interface. 


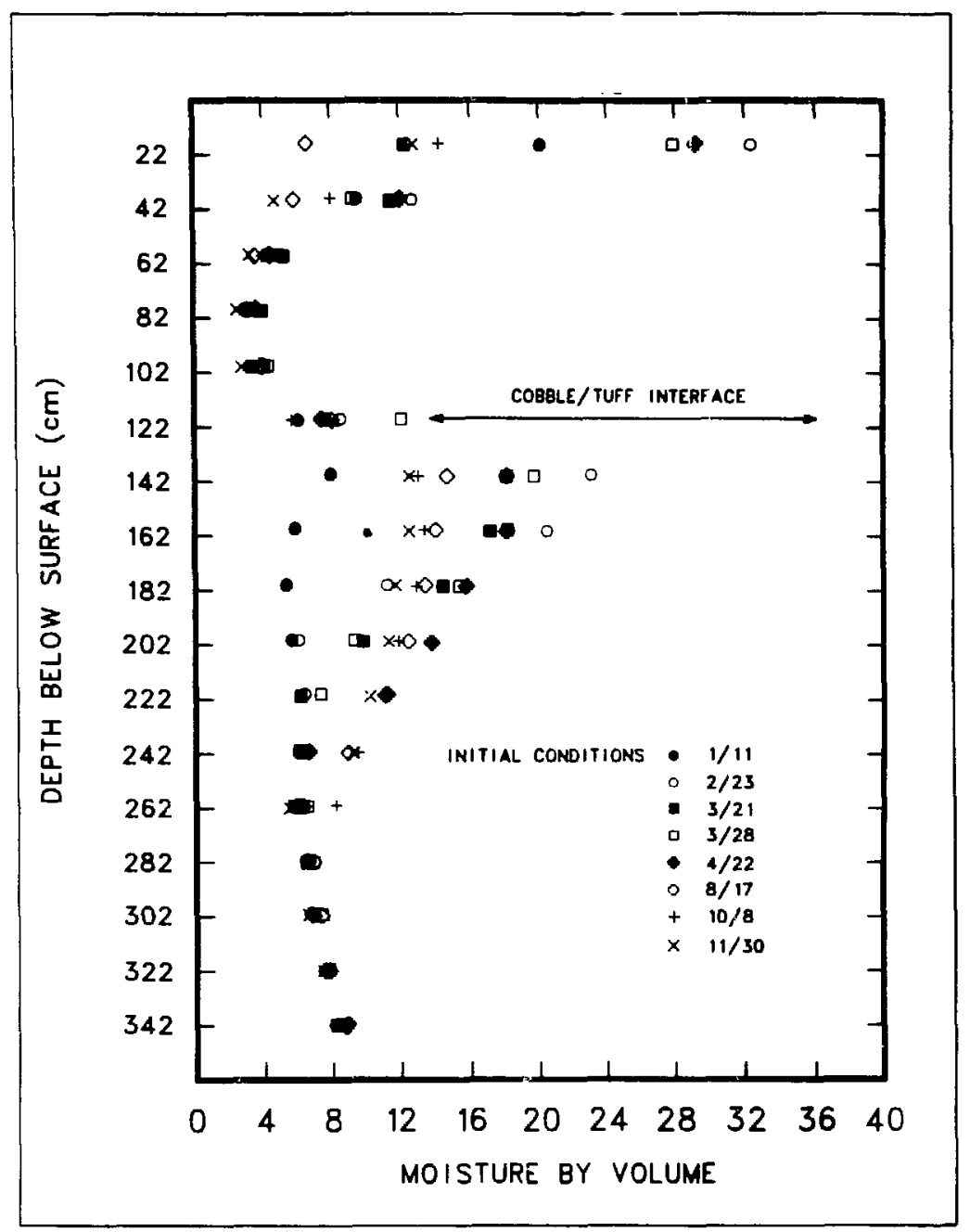

FIGURE 5.5. "Damping" of Moisture Pulses Under Field Conditions.

Figure 5.5 indicates the downward movement of the volumetric soll moisture pulses and the corresponding decrease in amplitude. The changes in soil moisture appear to be "damped" completely by $160 \mathrm{~cm}$ below the top of the crushed tuff. The general behavior of the pulses is similar to that observed in the first caisson and modeled in the first TRACR3D simulation. However, because of the initial low moisture levels and slightly smaller pulse inputs, the volumetric soll moisture pulse move is much slower and complete damping (defined as no detectable change in volumetric moisture) occurs at a higher horizon.

The field and simulation agreement is not as close as in the first caisson pulse experiment (Perkins and Travis 1985). In spite of the 
unknown material properties of the field fill and probably greater heterogeneity of the fill, the simulation results are in surprisingly good agreement. The "damping" point found in the simulation at $160-\mathrm{cm}$ is the same as was found experimentally.

\subsection{SURFACE HATER TRANSPORT MODELS}

\subsubsection{Multimedia Models}

Pacific Northwest Laboratry (PNL) and Los Alamos National Laboratory jointly developed a methodology for assessing air, water, and plant pathways from LLW as a part of an overall deveiopment effort of a LLW site evaluation methodology (Onishi, Whelan and Skaggs 1982 and 1983). The assessment methodology predicted $L L W$ exposure levels in the environment by simulating dominant mechanisms of LLW migration and fate. The methodology consisted of a series of physics-based models, which interact with each other to simulate $L L W$ transport in the ecosystem. A scaled-down version of the methodology was developed first by combining the Los Alamos terrestrial ecological risk model, BIOTRAN; the overland transport model, ARM; the instream hydrodynamic mode1, DKWAV; and the instream sediment-contaminant transport mode1, TODAM (a one-dimensional version of SERATRA.

The methodology was used to simulate the migration of $239 \mathrm{Pu}$ from a shallow land disposal site, Area $C$, located near the head of South Mortandad Canyon. The scenario assumed that $239 \mathrm{Pu}$ would be deposited on the land surface through the natural processes of plant growth, LLW uptake, dryfall, and litter decomposition. Runoff events would then transport $239 \mathrm{Pu}$ to and in the canyon. The model provided sets of simulated LLW levels in soil, water, and terrestrial plants in the region surrounding the site under a specified land-use and a waste management option. Over a 100-year simulation period, only an extremely small quantity $\left(6 \times 10^{-9}\right.$ times the original concentration) of buried 239pu was taken up by plants and deposited on the land surface. Only a small fraction (approximat $y$ 1\%) of that contamination was further removed by soll erosion from the site and carried to the canyon, where it remained. Hence, the study revealed that the environment around Area $C$ has integrity high enough to curtall $L L W$ mijration under recreational land use. 
Another study assessed the potential migration and fate of radionuclides in Los Alamos and Pueblo Canyons (Whelan, Thompson and Yabushi 1983). Specificaliy, a precipitation-generated flood event with a recurrence interval of 50 years in Los $A l$ amos and Pueblo Canyons simulated the degree to which radionuclides would migrate into lower Lus Alamos Cariyon.

Three numerical codes were selected to simulate overland runoff of a precipitation event and the resulting migration and fate of sediment and radionuclides in Acid-Pueblo Canyon. The Agricultural Runoff Management (ARM) (Donigian and Davis 1978) model simulated the movernent of flow and sediment overland to the stream's edge; the Modified Diffusion Wave with Seepage (MODSEEP) model simulated the instream hydrodynamics; and the Transient One-Dimeisional Degradation and Migration (TODAM) (Onisihi, Whelan and Skaggs 1982) modei simulated the instream migration and fate of sediment and radionuclides. The codes were calibrated on DP and Upper Los Alamos Canyons with partial records of data that exist for this area. A precipitation-producing flood event with a possible return period of 50 years was simulated in the Los Alamos area to investigate the migration of radionuclides downstream toward the Rio Grande.

Resuspension, deposition, sorption, migration, and fate of $239 \mathrm{Pu}$ adsorbed onto bed sediments were simulated. The scenario assumed the $239 \mathrm{Pu}$ concentrations currently existing at the modeling site as the initial conditions. A temporally varying, spatially uniform precipitation event representing a possible 50-year flood event was used in the modeling scenario. The 50-year event was chosen in an attempt to simulate a critical event (i.e., one which may transport and deposit significant amounts of $239 \mathrm{Pu}$ downstream).

\subsubsection{CREAMS Model}

The Chemicals, Runoff, and Erosion from Agricultural Management Systems (CREAMS) model has been successfully applied in waste management to simulate waste-site configurations that minimize soil erosion of trench caps into underlying buried wastes (Nyhan and Lane 1982).

The CREAMS model was originally developed in 1978 by the U.S. Department of Agriculture to evaluate nonpoint source pollution from agricultural 
lands (Knisel 1980). However, the CREAMS model has been successfully applied to shallow land burial systems in arid and semiarid areas of the West (Lane 1984).

The CREAMS model is a continuous simulation model to predict water balance. The model has hydrology, erosion, and chemistry components. The water balance concept and hydrology component of CREAMS are briefly described because they are important in this application.

The water balance for one-dimensional movement of water in the soil profile at a shallow land burial site is described by the equation:

$$
\frac{d s}{d t}=P-Q-E T-L
$$

$$
\begin{aligned}
& \text { where } \mathrm{ds} / \mathrm{dt} \\
& \begin{aligned}
\mathrm{P} & =\text { time rate change in soil moisture } \\
Q & =\text { precipitation } \\
E T & =\text { evapotranspiration } \\
L & =\text { seepage or percolation } \\
t & =\text { time. }
\end{aligned}
\end{aligned}
$$

CREAMS uses this equation to calculate the water balance of the soil profile to the plant rooting depth.

The hydrologic component predicts runoff and infiltration and maintains a soil water balance by simulating ET and percolation. This component has two options: (1) a daily rainfall run-off model based on the Soll Conservation Service runoff equation (U.S. Department of Agriculture 1972) and (2) an infiltration model based on the Green and Ampt infiltration equation (Green and Ampt 1911).

The soil profile, to the plant rooting depth, is represented in CREAMS by up to seven layers each with a representative depth or thickness and a water storage capar:ty. The evapotranspiration calculations are based on soil evaporation estiliates and plant transpiration estimates based on a leaf area index. Flow through the root zone is computed by using a soil storage-routing technique iased on the depth of the soil profile, the existing soil water content, and the sacurated hydraulic conductivity. 
Al though this procedure only computes saturated flow or percolation below the root zone, a soil water balance is maintained.

Soil water storage in each of seven layers is subject to evapotranspiration (ET) losses based on the rooting depth and the water use rate in the surface layer. The result is an estimate of ET as a function of the total rooting depth and as a function of the roots in each soil layer.

Model simulations were performed at experimental facilities of varying field scales at the Los Alamos Engineered Waste Burial Facility (Devaurs 1985). Soil moisture measurements were made in controlled experiments in caissons nearly at full field scale and at one field site in an actual shallow land waste disposal site. Data were from two experimental caissons, each 304.8-cm diameter and $609.6 \mathrm{~cm}$ deep. One caisson contained topsoil and crushed tuff; the second was filled with a mixture of topsoil, cobble, and gravel. The field site was decommissioned in 1948 and has lain fallow for 32 years (Area B). Experimental field plots at Area B are $40 \mathrm{~m} \times 40 \mathrm{~m}$. Various combinations of topsoil, backfill, gravel, and cobble were monitored at each site.

\subsection{ENVIRONMENTAL ASSESSME VT MODELS}

BIOTRAN model developrient began in 1974 with the goal of setting up a regional ecosystem model to determine the fate of plutonium and other transuranic elements in the Los Alamos environment. The early emphasis was on the transport of plutonium within soil, roots, and aboveground portions of agricultural crops. An initial study was performed by New Mexico State University on New Mexico crop irrigation schedules, crop identification, and livestock distributions, primarily in the Rio Grande Valley (Creel and Lansford 1975). This study resulted in an agricultural data base used for early verification and validation studies with the soil and plant portions of BIOTRAN.

Meteorologica 1, ruminant, and irrigation components were then added to BIOTRAN and resulted in the first model document by Gallegos, Garcia, and Sutton (1980).

Most of the early BIOTRAN modeling effort focused on transuranic element transport from radioactive wastes buried in trenches at Los Alamos. Thi: type of predictive modeling required a model with sufficient detail 
for the soil, water, and biotic transport mechanisms over long time frames of tens to thousands of years. A contract with Battelle at Hanford resulted in several studies where BIOTRAN was coupled to several other models to simulate the detailed mesa and canyon bottom hydrology at Los Alamos to provide a comprehensive assessment of transuranic canyon transport at Los Alamos (Onishi, Whelan and Skaggs 1982; Whelan. Thompson and Yabushi 1983). During the same period, BIOTRAN was used to assess several farming and grazing scenarios at Los Alamos and their effect on the solid waste management alternatives study (Walker et al. 1981). Current efforts with BIOTRAN involve coupling with CREAMS (Knisel 1980), a USDA sedimentation, fertilizer, and pesticide model, to perform extensive validations at Los Alamos and other sites.

Concurrent with the radioactive waste management risk analyses, BIOTRAN was applied to the Pantex Environmental Impact Statement (EIS) long-term risk analyses for uranium and plutonium accident scenarios (Wenzel and Gallegos 1982; Wenzel et al. 1982a; Wenzel et al. 1982b; Buhl et al. 1982). BIOTRAN was restructured into manageable subroutines after the Pantex EIS work and major new subroutines were added. A human physiology and kinetics model, HUMTRN, was coupled to BIOTRAN to develop age- and sex-specific human metabolism (Gallegos and Wenzel 1984).

HUMTRN was designed specifically as a major module of BIOTRAN to integrate climatic, hydrologic, atmospheric, food crop, and herbivore simulation witr. human dietary and physiological characteristics, and metabolism of radionuclides to predict radiation doses to selected organs of both sexes in different age groups. HUMTRN is based on age- and weight-specific equations developed for predicting human radionuclide transport from metabolic and physical characteristics. These characteristics are modeled from studies documented by the International Commission on Radiological Protection (ICRP 23) (1975). HUMTRN allows cumulative dGses from radionuclides to be predicted by modeling age-specific anatomical, physiological, and metabolic properties of individuals between 1 and 85 years of age and can track radiation exposure and radionuclide metabolism for any age group for specified daily or yearly time periods. The simulated dally dose integration of eight or more simultaneous air, water, and food intakes gives a comprehensive, dynamic picture of radionuclide intake, uptake, and hazard analysis for complex scenarios. 
Shortly after development of the HUMTRN model, two risk assessment models were developed, REPCAL (Buhl and Hansen 1984) and EFFECTS (Wenzel and Gallegos 1985).

The recommendations of the BEIR III (1980), UNSCEAR (1977), and ICRP (1977) reports were summarized and compared by Buhl and Hansen (1984). Based on this review, two procedures for risk estimation were presented for use in radiological assessments. In the first procedure, age- and sexaverage risk estimators calculated with U.S. average demographic statistics were used with estimates of radiation dose to calculate the projected risk of cancer and genetic disorders. If more site-specific risk estimators are needed, and the demographic information is available, a second procedure was described that would involve direct calculation of the risk estimators by using recommended risk-rate factors. The computer program REPCAL was written to perform this calculation and is described by Buhl and Hansen (1984).

The computer simulation code EFFECTS is coupled with the radionuclide uptake and environmental transport strategies of the BIOTRAN code to predict cancer risks and deaths in a dynamic human population (Wenzel and Gallegos 1985). Included as part of the EFFECTS model is a generalized population dynamics portion representative of the current U.S. population mortality and natality characteristics. The population characteristics are integrated with BEIR III radiation cancer mortality estimates. Males and females between 1 and 85 years old are treated separately. Natality of both sexes are simulated by using current U.S. population birthrates on an annual basis. Total mortalities due to all causes are incorporated with projected radiation-induced cancer mortalities from all previous chronic or acute radiation exposures to the population as a function of age and sex. The super-positioning of radiation-induced cancer mortalities on current total mortalities in each age group allows a realistic and dynamic estimate of cancer risks for complex radiation exposure scenarios. EFFECTS was developed on the CDC 7600 computer and can be executed on the CRAY and VAX/VMS computer systems at Los Alamos. EFFECTS can simulate the upper boundary of cancer risk estimates where population exposures occur over many years and organ burdens are integrated over the lifetime of the individual. 
Utilizing the systematic graphics verification techniques developed for BIOTRAN, EFFECTS has made possible the dynamic simulation of the release and movement of contaminants in a simulated environment and the visualization of the effects on plants, animals, and human populations. With the ability to plot over 20,000 lines of output in one 3-D graph, we can now rapidly verify complex scenarios.

BIOTRAN has recently been extended to simulate the fate of the macronutrients nitrogen, phosphorus, potassium, and calcium in detail.

Figure 5.6 illustrates the current structure of BIOTRAN. The CLIMAT subroutine is the major driver of a simulation by supplying precipitation, insolation, temperature, and potential evapotranspiration to the other subroutines. Biomass, water, and radionuclides are then transferred within the other subroutines as a function of time by using daily intervals that are summed within a yearly loop. The smallest time interval is the $24-h$ day for which all variable incremerits in each subroutine are calculated. Table 5-4 gives a short description of each subroutine.

BIOTRAN is driven stochastically in a Monte Carlo fashion by the CLIMAT subroutine by using random number generators to vary rainfall and temperature. Precipitation and temperature then determine, for example, the water layer temperatures in AQUAT, the soil moisture input for WATFLX, the growing season for the plants simulated in PLTGRO, and the transport rates of radionuclides in UPTAKE. The short- and long-term effects of the climate determine the eventual concentration of radionuclides in the soil, vegetation, and animals. Considerable attention is focused on developing reliable input for the CLIMAT subroutine.

Simulations can be run for a minimum of 1 year, with each day's variables available, up to many hundreds or thousands of years. Execution time for a simple CLIMAT subroutine run can be as small as fractions of a second or, for large inputs execution time, is over $1000 \mathrm{~s}$ on the $\operatorname{CDC} 7600$. Once the scenario is carefully defined, i.e., the simulation time interval, the acute or chronic air concentration pulses, the soil radionuclide levels, and the harvest and diet schedules for animals and humans, then the user can construct the input in stages and verify the output graphically. The input file can be as small as 18 lines or can be several hundred lines, depending on the complexity of the scenario. 


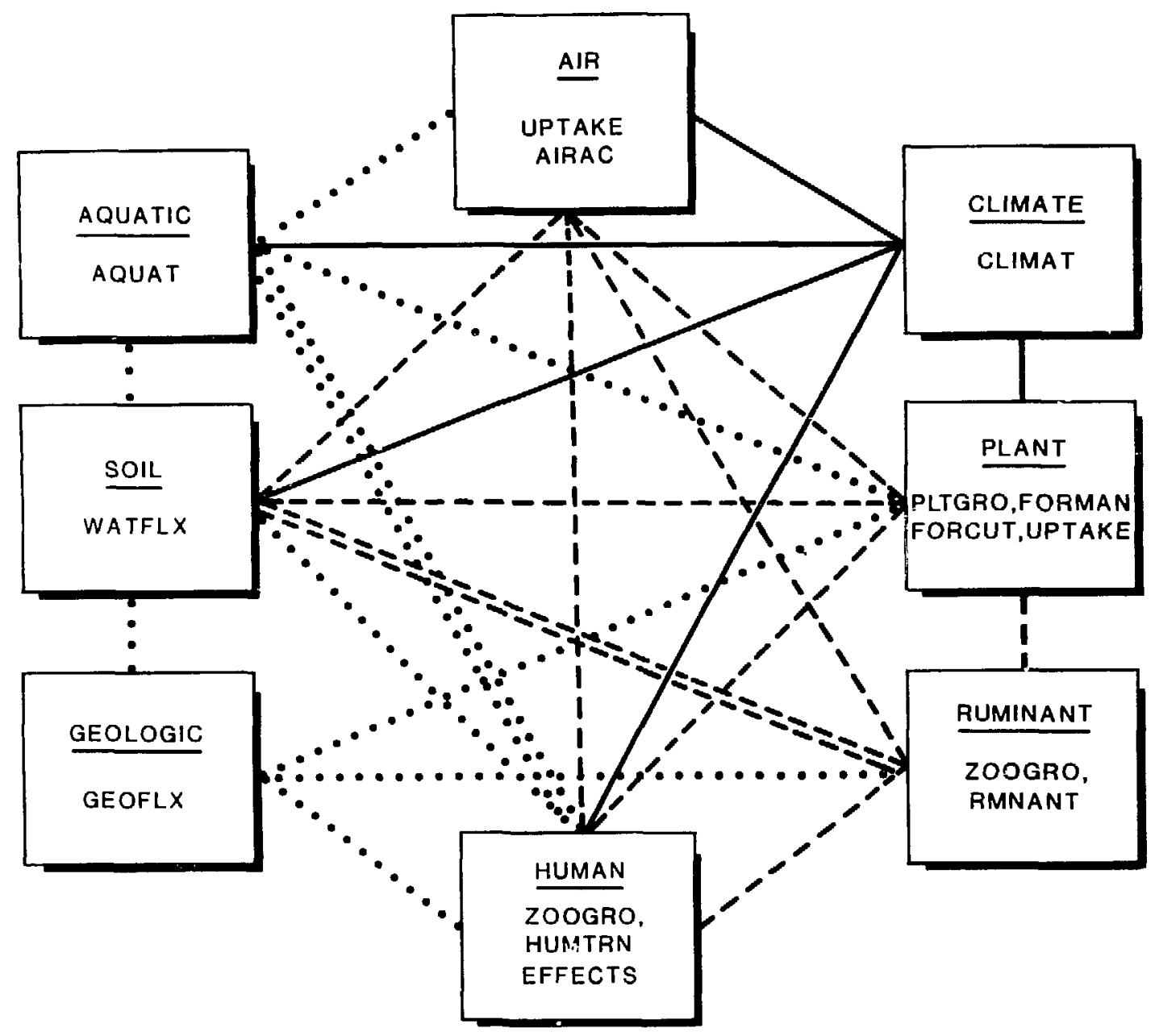

FIGURE 5.6. BIOTRAN Model Structure. 
TABLE 5-4. List of Subroutines for the BIOTRAN Model

Subroutine

Name

Description of Major Processes Modeled

CLIMAT ${ }^{(a)}$

Climatic daily temperature, solar radiation, precipitation, and potential evapotranspiration "driver" for BIOTRAN.

BIOPLT Selector for graphical or formatted output.

AIRAC

WATFLX

$\operatorname{PLTGRO}(a)$

User specified acute or chronic average daily air radionuclide concentrations from accidental releases, fallout, or ambient air data by selecting which days in particular years of the simulation.

Simulates daily soil profile moisture flux and potential evapotranspiration for a particular soil and plant type. Simulates above- and belowground live and dead biomass dynamics for 22 different plant types (grasses, forbs, shrubs, and trees).

UPTAKE (a) Simulates radionuclide transport by wind, rainfall, and root uptake resulting in radionuclides in and on plants.

RUMNANT Simulates ruminant metabolism and radionuclide intake, uptake, and burden based on daily diet regime of simulated forage and feed.

ZOOGRO Harvests and stores simulated crops for ruminant and human consumption. Manages ruminant grazing.

HUMTRN

Simulates age- and sex-specific human physiology; radionuclide intake, uptake, and dose based on daily diet regime of simulated milk, meat, vegetables, and grain. Individual doses are calculated on an age- and sex-specific basis.

EFFECTS Simulates age- and sex-specific human cancer risk and deaths from the radiation exposure and body burdens calculated by HUMTRN. Uses 3-D graphics to look at population dynamics and risk.

FORCUT Adjusts biomass for forest fire events and selective cuttings.

FORMAN Simulates forest stand characteristics on a daily or yearly basis.

FORCUT Adjusts biomass for forest fire events and selective cuttings.

AQUAT (Under Development.) Simulates daily limnetic and littoral water characteristics, plankton, plants, and fish.

GEOFLX (Under Development.) Simulates daily and yearly water and radionuclide flow through geologic formations.

(a) These subroutines are called during all simulations, whereas the others are user controlled. 
f.beele, H. V., M. L. Wheeler and B. W. Burton. 1981. Geohydrology of Bandelier Tuff. LA-8962-MS, Los Alamos National Laboratory, Los A New Mexico.

Abeele, W. Y. 1984. Hydraulic Testing of Crushed Bandelier Tuff. LA-10037-MS, Los Al amos Na tional Laboratory, Los ATamos, New Mexico.

Aikens, A. E., Jr., et al. 1979. Generic Methodology for Assessment of Radiation Doses from Ground Water Thigration of Radionuclides in LWR Wastes in Shallow Land Burial Trenches, Revision 3. AID/NESP-013, A tomic Industrial Forum, Washington, Jic.

BEIR III. 1980. The Effects on Populations of Exposure to Low Levels of Radiation: 1980. Nat7. Res. Council, Natl. Acad. Science, Committee on the binl. Effects of Innizing Radiation, Natl. Academy Press, Hashington, DC.

Buhl, T., et al. 1982. Supplementary Documentation for an Environmental Impact Statement Regirding the Santex Plant: Radiation Monitoring and Radiological Assessmeent of Routine Releases. LA-9445-PNTX-C, Los A7amos National Laboratory, Los Alamos, New Mexico.

Buhl, T., and W. R. Hansen. 1984. Esstimating the Risks of Cancer Mortality and Genetic Defects ResuTting from Exposure to Low Leve is of Ionizing Radiation. LA-9895-MS, Los Alamos Nationa7 Laboratory, Los Alamos, New Hiexico.

Creel, B. J., and R. R. Lansford. 1975. Agricultural Resource Base Data for: Environmental Evaluation of Toxic Waste Burial Sites and Their U1timate Disposition. Dept. Agricultural Economics and Agricultural Business.

DePoorter, G. L., W. V. Abeele and B. W. Burton. 1982. "Experiments to Determine the Migration Potentiai for Water and Contaminants in Shallow Land Buria! Facilities: Design, Emplacement, and Preliminary Result's, Waste Management '82, Vol. II." In Proceedings of the Symposium on Waste Hänagement. Tucson, Arizona, March 8-11, 1982, pp. 649-655.

Devaurs, M. 1985. Use of CREAMS Model in Experimental Designs for Shallow Land Burial of Low Level Wastes. LA-JR-85-663, Los Alamos National Laboratory, Los Alamos, New Mexico.

Donigian, A. S., Jr., and H. H. Davis, Jr. 1978. User's Manual for Agricultural Runoff Management (ARM) Model. EPA-600/3-78-080, 0ffice of Research and Development, U.S. EPA, Washington, DC. 
Dunning, D. E., et a1. 1981. Estimates of Internal Dose Equivaient to 22 Target Organs Occurring in Routine Releases from Nuclear Fuel Cycle FaciTities, Vol. III. NUREG/CR-0150, Nuclear Regulatory Commission, Washington, DC.

Gallegos, A. F., and W. J. Wenzel. 1984. ICRP-Based Age- and Sex-Specific Human Simulation Model for Radionuclide Dose Assessment. LA-9994-MS, Los Alamos National Laboratory, Los ATamos, New Mexico.

Gallegos, A. F., B. J. Garcia and C. M. Sutton. 1980. Documentation of TRU Biological Transport Model (BIOTRAN). LA-8213-MS, Los Alamos National Laboratory, Los Alamos, New Mexico.

Green; H. A., and G. A. Amp'c. 1911. "Studies on Soil Physics, 1. The Flow of Air and Water Through Soils." J. of Agricultural Science. 2:1-24.

Hansen, W. R., and J. C. Rodgers. 1983. "Risk Analyses for Shallow Land Burial and Greater Confinement of Alpha-Contaminated Wastes." Nuclear and Chemical Waste Management. 4:81-94.

Healy, J. $\because .$, and J. C. Rodgers. 1979. Limits for the Burial of Department of Energy Transuranic Wastes. LA-UR-79-100, Los Alamos National Laboratory, Los Alamos, New Mexico.

International Commission on Radiological Protection (ICRP). 1975. Report of the Task Group on Reference Man. ICRP Publication 23, Pergamon Press, oxford.

International Commission on Radiological Protection (ICRP). 1977. Recommendations of the International Commission on Radiological Protection. ICRP Publication 26, Pergamon Press, New York.

Jackson, R. E., and K. J. Inch. 1980. Hydrogeochemical Processes Affecting the Migration of Radionuclides in a Fluvial Sand Aquifer at the Chalk River Nuclear Laboratories. National Hydrology Research Institute Paper No. 7, Ottawa, Canada.

Knisel, W. G., Jr. 1980. CREAMS: A Field Scale Model for Chemicals, Runoff, and Erosion from AgxicuTtural Management Systems. USDA Cons. Res. Rep. No. 26, U.S. Department of Agriculture, Washington, DC.

Lane, L. J. 1984. Surface Water Management: A User's Guide to Calculate a Nater Balance Using the CREAMS Model. LA-10177-M, Los Alamos National Laboratory, Los Alamos, New Mexico.

Lester, D. H., G. Jansen and H. C. Burkholder. 1979. "Migration of Radionuclide Chains Through an Adsorbing Medium." In AICHE Symposium Series, Adsorption and Ion Exchange. 171 (152). 
Nyhan, J. W., and L. J. Lane. 1982. "Use of a State-of-the-Art Model in Generic Designs of Shallow Land Repositories for Low Level Wastes." In Waste Management '82. Proc. of the Symposium on Waste Management at Tucson, Arizona, pp. 235-244.

Onishi, Y., G. Whelan and R. L. Skaggs. 1982. Development of Multimedia Radionuclide Exposure Assessment Methodology for Low-Level Waste Management. PNL-3370, Pacific Northwest Laboratory, Richland, Washington.

Onishi, Y., G. Whelen and R. L. Skaggs. 1983. Development of a Multimedia Radionuclide Exposure Model for Low-Level Weste Management. PNL-3370, Pacific Northwest Laboratories, Richland, Washington.

Perkins, B., and B. Travis. 1985. Soil Water Flow Under Saturated/Unsaturated Conditions--Validation of the TRACR3D Code in Three Experimen:s. Los Alalios National Laboratory, Los Alamos, New Mexico.

Travis, B. J. 1984. TRACR3D: A Model of Flow and Transport in Porous/ Fractured Media. LA-9667-MS, Los ATamos National Laboratory, Los ATamos, New Mexico.

United Nations Scientific Comattee on the Effects of Atomic Radiation. 1977. Sources and Effects of Ionizing Radiation. New York.

U.S. Department of Agriculture. 1972. Soil Conservation Service, National Engineering Handbook, Section 4, "Hydrology." U.S. Department of Agriculture, SCS, Washington, DC.

Vine, E. N., et al. 1981. "Radionuclide Transport and Retention in Tuff." In The Scientific Basis for Nuclear Waste Management 3:483, Plenum Press, New York.

Walker, L. J., et al. 1981. Alternative Transuranic Waste Management Strategies at Los Alamos National Laboratory. LA-8982-NS, Los ATamos National Laboratory, Los A7amos, New Mexico.

Wenzel, W. J., and A. F. Gallegos. 1982. Supplementary Documenta ion for an Environmental Impact Statement Regarding the Pantex Plant: Long-Term Radiologi ial Risk Assessment for Postulated Accidents. LA-9445-PNTX-D, Los Alamos National Laboratory, Los Alamos, New Mexico.

Wenzel, W. J., and A. F. Gallegos. (1985). "EFFECTS: Documentation and Verification for a BEIR III Cancer Risk ModeT Based on Age, Sex, and Population Dynamics. LA-10371-MS, Los ATamos National Laboratory, Los ĀTamos, New Mexico.

Wenze 1, W. J., et al. 1982a. Supplementary Documentation for an Environmental Impact Statement Regarding the Pantex PTant: Agricultural Food Chain Radiological Assessment. $[A-9445-P N T X-M$, Los Alamos National Laboratory, Los Alamos, New Mexico. 
Wenzel, W. J., et al. 1982b. "The Texas Panhandle Sol1-Crop-Beef Food Chain for Uranium: A Dynamic Model Validated by Experimental Data." In Fourth DOE Environmental Protection Information Meeting, CONF-821215, Denver Hflton, Denver, Colorado.

Wheeler, M. L., W. J. Smith and A. F. Gallegos. 1977. A Preliminary Evaluation of the Potential for Plutonium Release from Burlal Grounds at the Los ATamos Scientific Laboratory. LA-6694-MS, Los ATamos Scientific Laboratory, Los ATamos, Néw Mexico.

Whelan, G., F. L. Thompson and S. B. Yabushi. 1983. Murtimedia Contaminant Environmental Exposure Assessment Methodology as Applied to Los Alamos, New Mexico. PNL-4546, Pacific Northwest Laboratory, RTchland, Washington. 


\section{ACKNOWLEDGMENTS}

Many people assisced the assembly of this document. Our thanks go to John Warren, HSE-7; Jack Nyhan, HSE-12; Tom Buhl, HSE-8; Naomi Becker, HSE-8; and Michelene Devaurs, HSE-8, for technical assistance. For preparation and word processing, we thank Kathy Derouin and Mary Lou Keigher for their heroic efforts. We also appreciate the lorig hours of patient editing done by Virginia Reichelt. 